
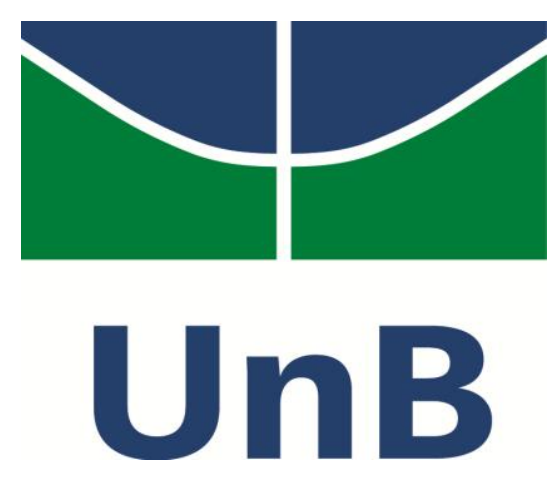

UNIVERSIDADE DE BRASÍLIA

INSTITUTO DE LETRAS

DEPARTAMENTO DE LINGUÍSTICA, PORTUGUÊS E

LÍNGUAS CLÁSSICAS

PROGRAMA DE PÓS-GRADUAÇÃo EM LINGUÍSTICA

A GRAMÁTICA DO PRECONCEITO: ESTUDO COGNITIVO-FUNCIONAL DO DISCURSO JORNALÍSTICO SOBRE O INDÍGENA BRASILEIRO

Isabella Siqueira Toguchi

Brasília - DF

2016 
Isabella Siqueira Toguchi

\section{A GRAMÁTICA DO PRECONCEITO: ESTUDO COGNITIVO-FUNCIONAL DO DISCURSO JORNALÍSTICO SOBRE O INDÍGENA BRASILEIRO}

Dissertação apresentada ao Programa de PósGraduação em Linguística do Departamento de Linguística, Português e Línguas Clássicas, Instituto de Letras, Universidade de Brasília, como requisito parcial para a obtenção do Grau de Mestre em Linguística, na área de concentração de Teoria e Análise Linguística.

Orientador: Prof. Dr. Dioney Moreira Gomes 
Isabella Siqueira Toguchi

BANCA EXAMINADORA

Prof. Dr. Dioney Moreira Gomes - UnB (presidente)

Prof $^{a}$ Dr $^{a}$ Walkíria Neiva Praça - UnB (membro efetivo interno)

Prof. Dr. Fernando Oliveira Paulino - UnB (membro efetivo externo)

Prof. Dr. Umberto Euzebio- UnB (membro suplente) 
A consequência de uma única história é essa: ela rouba das pessoas sua dignidade. Faz o reconhecimento de nossa humanidade compartilhada difícil. Enfatiza como nós somos diferentes ao invés de como somos semelhantes. (Chimamanda Ngozi Adichie) 


\section{Agradecimentos}

À minha família e, em especial, à minha mãe, Dalva, que me deu as mais preciosas e perenes heranças possíveis: caráter e educação. Agradeço por ter me apoiado incondicionalmente sempre.

Ao meu irmão, Matheus, que sempre esteve ao meu lado, até mesmo quando um oceano nos separava. Obrigada pelas “caminhadas de irmãos”, conselhos, broncas e carinho.

Agradeço ao incomparável mestre, Prof. Dr. Dioney Gomes, cuja orientação norteou não apenas este trabalho, mas toda a minha prática docente e acadêmica. Obrigada por ser o modelo de educador de que tantos estudantes precisam. Obrigada pelas inúmeras e valiosíssimas conversas e orientações.

Aos professores do IL: Orlene Sabóia, Michelle Vilarinho, Walkíria Praça, Cibele Brandão, Ana Adelina Ramos, Maria Luiza Coroa, Raquel Dettoni, Messias Ramos, Saulo Machado pelos ensinamentos. Em especial, agradeço ao prof. Cesário Alvim, sem cuja ajuda eu não teria conseguido nem mesmo iniciar este trabalho.

Aos “irmãos de orientação”: Tiago Aguiar, Letícia Sallorenzo, Nathália Costa, Tânia Borges, Maria Cristina e Luísa Barbosa pelas companhias nos congressos e encontros.

Aos amigos da "corja”: Wagner Santos, Roberta Ribeiro, Renata Antunes, Paula Guedes, Ana Paula Azevedo, Edinizis Belusi, Nara Justiniano e Marcos Mendonça. Unidos à força no começo, mas cujo apoio foi fundamental nesses anos.

Aos amigos Márcia Cristofio, José Feliciano Câmara e Mariana Câmara por entenderem minhas inúmeras ausências durante esse processo e por me proporcionarem preciosos momentos de descontração e alegria.

Ao querido Dario Sensi por ser mais que um companheiro, por acreditar em mim mais do que eu mesma. Por ter vibrado a cada conquista minha, por ter se interessado pelo trabalho, lembrado de mim cada vez em que (ou)via a palavra "indígenas". A ele todo meu carinho, amor e admiração. 


\title{
RESUMO
}

O presente trabalho tem como objetivo analisar as estruturas linguísticas presentes nas notícias veiculadas pelos portais de notícia G1, O Globo e Folha de S. Paulo com temática indígena no período de janeiro de 2012 a janeiro de 2015. Por meio de um olhar da Linguística Funcional Centrada no Uso verificamos quais estruturas morfossintáticas são eleitas para relatar os acontecimentos relativos aos povos indígenas. Por outro lado, analisamos algumas estruturas definidas por van Dijk como estratégias discursivas para reificar o racismo do dia a dia. Também observamos quais os critérios de noticiabilidade mais presentes nos jornais quando a notícia tem a temática indígena. Como partimos de uma perspectiva funcionalista, defendemos que as estruturas estão a serviço da função e, ao fim deste trabalho, apresentamos como elas estão a serviço de uma construção negativa da representação das comunidades indígenas na sociedade brasileira. Destacaremos os padrões estruturais que encontramos nessas notícias. Tais padrões nos mostraram que existe sim uma estrutura que é eleita para tratar da temática indígena e que a imagem que se constrói sobre o indígena brasileiro é predominantemente negativa.

Palavras-chave: Povos indígenas. Linguística Centrada no Uso. Linguística Cognitivofuncional. Mofossintaxe. Cognição.

\begin{abstract}
The main purpose of this paper is to analyze the linguistics structures present in news in Brazilian newspapers Gl and Folha de S. Paulo about Brazilian indigenous people in the period from January 2012 to January 2015. Under the usage based linguistics view, we are going to verify which morphosyntatic structures are choosen to report events concerning indigenous communities. On the other hand, we are going to analyze some microstructures defined by van Dijk as discoursive strategies to reify everyday racism. Finally, we will point out which newsworthiness appear more often when the event regards the indigenous. As our starting point is the American functional-typological analysis, we assume that the structures are modeled by their functions. As a result, we demonstrate that those structures build a negative representation of indigenous communities in Brazil. We are going to highlight the structures that were used in those news. Those patterns showed us that, in fact, there is a structure that is preferred to talk about the indigenous and the image that is constructed of them is mainly negative.
\end{abstract}

we are going to show how it happens in a way to inferiorize the indigenous communities in Brazilian society.

Key-words: Indigenous. Usage Based Linguistics. Morphosyntax. Cognition 


\section{Lista de Tabelas / Quadros/ Figuras}

Tabela 1 - Resultado da pesquisa sobre notícias envolvendo temática indígena no jornal O Globo. .77

Tabela 2 - Resultado da pesquisa sobre notícias envolvendo temática indígena no jornal Folha de SP. .77

Figura 1 - Escala de topicalidade/ agentividade..................................24

Figura 2 - O contrato social da comunicação......................................64

Figura 3 - Esquema da notícia.........................................................67

Quadro 1 - Exemplo de notícia sobre povos indígenas brasileiros...........12

Quadro 2 - Modelo de dominação de Thompson.......................................46

Quadro 3 - Critérios de noticiabilidade..................................................69

Quadro 4 - Protocolo de análise textual.................................................79 


\section{SUMÁRIO}

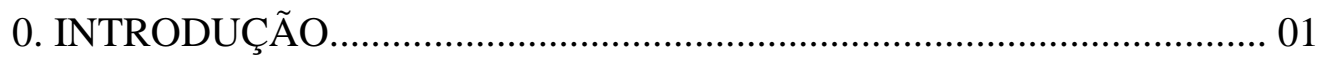

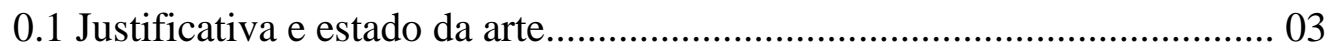

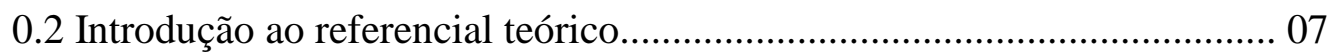

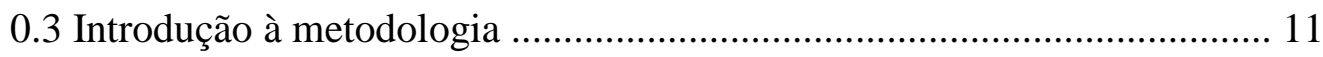

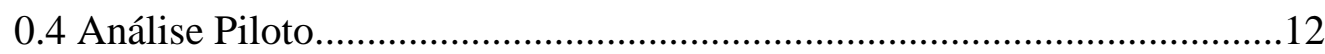

CAPÍTULO 1: Linguística Funcional Centrada no Uso ou Cognitivo-Funcional

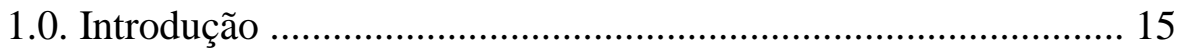

1.1 Linguística Funcional Centrada no Uso (Usage-based Linguistics) ou

Linguística Cognitivo-Funcional ..................................................15

1.2. Construtos do Funcionalismo Tipológico ..................................18

1.2.1 Relações Gramaticias ........................................................19

1.2.2 Papéis Semânticos .............................................................20

1.2.3 Papéis Pragmáticos ..........................................................23

1.2.4 Voz verbal strictu sensu e lato sensu ...............................25

1.2.5 Valência sintática ...............................................................27

1.2.6 Valência Semântica .............................................................28

1.2.7 Operações que alteram valência ..........................................29

1.2.7.1 Operações que reduzem valência ................................30

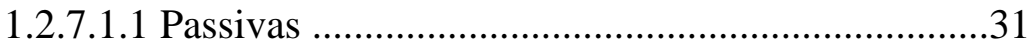

1.2.7.2 Operações que aumentam valência..............................33

1.2.7.2 Causativas morfológicas, lexicais e perifrásticas ...33

1.3 Construtos da Linguística Cognitiva ...........................................35

1.3.1 Categorização e Protótipo ....................................................35

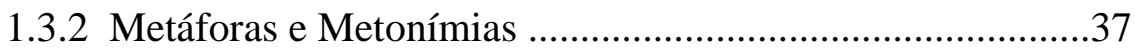

1.3.3 Iconicidade e Iconicidade Diagramática ............................39 
1.3.4 Frames, estereótipos e modelos cognitivos 40

1.4 Resumo do capítulo 42

CAPÍTULO 2: Discurso, Ideologia e Comunicação de Massa

2.0 Introdução .43

2.1 Discurso, ideologia, estereótipo e identidade/representação .....43

2.1.1 Discurso .43

2.1.2 Ideologia/Modelo de dominação de Thompson .45

2.1.3 Estereótipos . .47

2.1.4 Identidade/Representação . .49

2.2 Discurso e texto .51

2.2.1 Tópico .52

2.2.2 Implicações e pressuposições .53

2.2.3 Coerência local .54

2.2.4 Sinônimos e Contraste .55

2.2.5 Contraste .55

2.2.6 Exemplos e Ilustrações .56

2.2.7 Disclaimers .56

2.2.8 Modalidade .57

2.2.9 Evidencialidade .57

2.2.10 Vaguidade 58

2.2.11 Contexto .58

2.2.12 Racismo do dia a dia .59

2.2.13 Escolhas lexicais .60

2.2.14 modelos mentais 60

2.2.15 Topoi 61

2.3 Meios de Comunicação de massa 61

2.3.1 Agenda-setting 63

2.3.2 A notícia e sua estrutura .64

2.4 Critérios de noticiabilidade .68

2.5 Resumo do capítulo . .70 
CAPÍTULO 3: Percursos Metodológicos

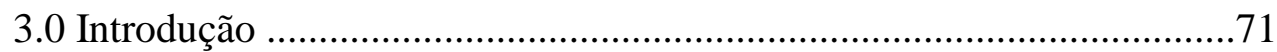

3.1 A pesquisa documental e qualitativa ..................................................

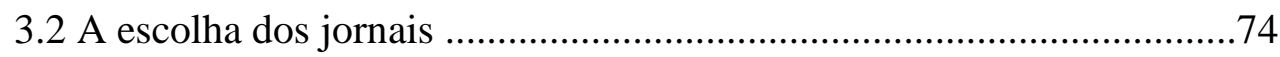

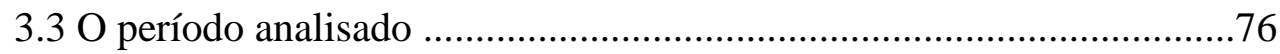

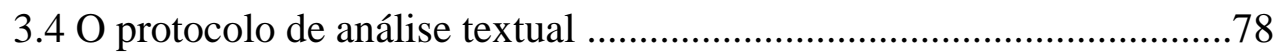

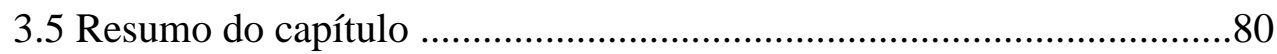

CAPÍTULO 4: Análise das notícias

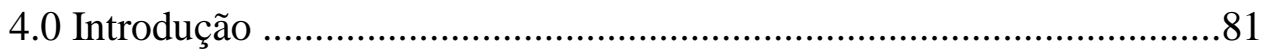

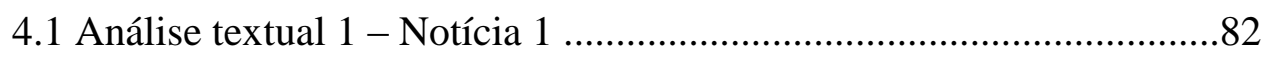

4.1.1 Síntese da análise textual da Notícia 1 ......................................97

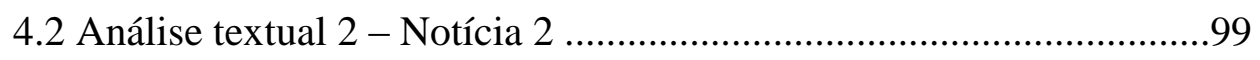

4.2.1 Síntese da análise textual da Notícia 2 ....................................118

4.3 Análise textual 3 - Notícia 3 ......................................................121

4.3.1 Síntese da análise textual da Notícia 3 .....................................137

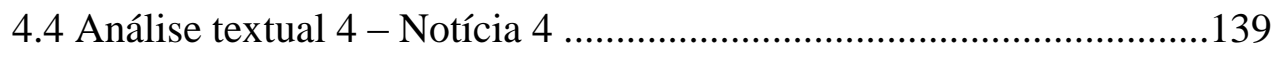

4.4.1 Síntese da análise textual da Notícia 4 ....................................152

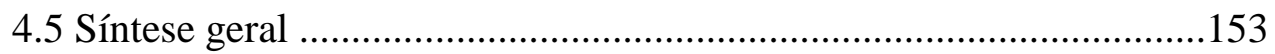

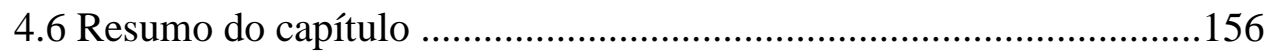

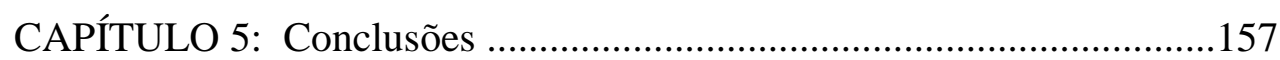

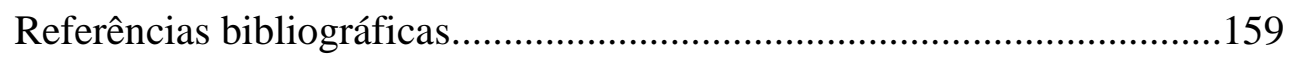




\title{
0. Introdução
}

O presente trabalho tem como objetivo analisar textos jornalísticos que tratam da temática "indígena” na mídia brasileira. Por um lado, a partir de um prisma da linguística centrada no uso, pretende-se verificar quais arranjos morfossintáticos, sintáticos, semânticos, pragmáticos, discursivos e escolhas lexicais são usadas preferencialmente pelo jornalismo no tocante aos povos indígenas ${ }^{1}$ brasileiros; por outro, espera-se investigar qual representação se constrói sobre o indígena, considerando os critérios de noticiabilidade de Wolf e Bond (WOLF \& FIGUEIREDO 2009), além dos estudos de van Dijk sobre discurso, sociedade e ideologia (2003).

Para levar a cabo tal pesquisa, as estruturas encontradas no discurso jornalístico foram consideradas e analisadas sob a ótica do Funcionalismo, especialmente da Linguística Centrada no Uso, pois acreditamos que:

\begin{abstract}
Existe um conteúdo ideacional no enunciado, mas há um modo pelo qual ele é organizado para apresentação ao ouvinte, o qual depende não apenas do modo pelo qual se arranjam entidades como sujeito e predicado, mas também no modo pelo qual se arranjam entidades informativas (pragmáticas) como tópico e comentário ou dado e novo. Compõe-se, pois, um fluxo de informação, controlado por um fluxo de atenção e um ponto de vista (De Lancey,1981) que determina a sequência que o falante considera adequada para obter a atenção do ouvinte.
\end{abstract}

(NEVES, 2004, p. 24)

A fim de entendermos quais estratégias linguísticas a mídia utiliza para obter/manipular a atenção de seus leitores, analisamos notícias jornalísticas, pois esse discurso pode (des)construir realidades, afirmar/rejeitar estereótipos e criar representações. Tendo em vista que a sintaxe não é autônoma para o Funcionalismo e que as estruturas linguísticas, via de regra, atendem a anseios pragmáticos e discursivos, verificamos, por exemplo, quais estratégias de aumento de valência, de redução de valência e/ou de voz verbal são tipicamente usadas para construir textos jornalísticos escritos sobre a temática indígena. Identificamos que as estruturas de voz e valência, assim como as metáforas, as metonímias e escolhas lexicais são manipuladas de forma a mostrar apenas um ponto de vista sobre os acontecimentos.

Os mais de 200 povos indígenas brasileiros, sendo uma minoria marginalizada, têm tido sua voz silenciada pela sociedade. A mídia, considerada sinônimo de prestígio cultural, é uma das principais formas de atingir uma grande parcela da população que está alheia às questões

\footnotetext{
1 Segundo dados divulgados pela Funai e IBGE, o censo demográfico em 2010 contabilizou 305 diferentes etnias no Brasil. O censo tem como base as pessoas que se declararam indígenas no quesito cor ou raça e as pessoas que residem em terras indígenas e se consideram, mas não se declararam.
} 
que dizem respeito aos direitos indígenas. Mota (2012) nos lembra que a comunicação é uma questão que ultrapassa a mediação; não é só mais conhecimento, porém também reconhecimento. Não há identidade cultural que não seja contada. Ou seja, a identidade cultural é formada não só pelo conhecimento e reconhecimento de um determinado grupo sobre si próprio, mas também pelos valores que outros grupos atribuem a ele.

Segundo van Dijk (apud SOUSA, 2000, p.42), “a organização da produção jornalística privilegiaria acontecimentos produzidos/definidos por figuras públicas e setores preponderantes da vida social e política, reproduzindo uma estrutura social favorável a essas elites". Podemos inferir, portanto, que a mídia estabelece, sim, critérios para definir quais grupos sociais seriam notícia e como seriam representados. Hall (1993, p. 228) lembra que "os media definem para a maioria da população quais os acontecimentos significativos que ocorrem e, também, oferecem poderosas interpretações de como compreender esses acontecimentos".

De acordo com Giacomeli (2008, p. 15),

Pesquisadores não só do meio jornalístico, mas também sociólogos, psicólogos e até antropólogos debruçaram-se sobre o assunto [noticiabilidade]. Formularam-se várias teorias para explicar o uso dos conceitos de noticiabilidade, também chamados de "valores-notícia".

Sobre noticiabilidade, Aldé, Xavier, Barretos e Chagas (2005, p. 187) relatam: "Acreditamos que, em certa medida, este discurso influi sobre os critérios que adotam no momento de escolher pautas e fontes, atribuir relevância editorial, descartar possíveis temas, problemas e matérias como não dignos de serem publicados".

Os valores-notícia, conforme aponta Mota (2012), levam a uma construção hegemônica do conhecimento, pois a voz por trás da notícia é de alguém que está em uma posição de poder elevada. Os jornais, segundo a autora, se tornam porta-vozes e estabelecem uma primeira interpretação do tema abordado, que servirá de guia para interpretações futuras. Novas interpretações culturais serão fixadas ou reforçadas de forma desigual, contribuindo para a manutenção de uma hegemonia.

Nessa linha de raciocínio, inclui-se, neste trabalho, a seguinte indagação: os critérios de noticiabilidade potencialmente reforçam o preconceito aos indígenas, fazendo com que esses sejam retratados apenas em situações extremas ou de maneira negativa? 


\title{
0.1 Justificativa e estado da arte
}

Há mais de 200 comunidades indígenas vivendo no Brasil. A representação indígena difundida na mídia e sua análise linguística que fazemos aqui são importantes, pois ainda hoje encontramos uma situação de preconceito contra esses grupos, sobretudo no discurso oficial sobre eles. As escolhas das estruturas gramaticais das notícias e chamadas presentes nos jornais ajudam a reforçar essa representação negativa construída socialmente, seja pela manipulação da informação ou pela desinformação proposital. Serva (2001, p. 7) afirma:

\begin{abstract}
A desinformação acontece, curiosamente, numa época de esplendor dos recursos técnicos e quando os profissionais dessa área dispõem de um background que em princípio os habilita mais do que nunca ao exercício de suas funções. Observa-se, por exemplo, que, nos países que controlam a informação, seu uso se faz não para dar conta da realidade, e sim para mudá-la, moldá-la, alterá-la segundo os interesses do governo.
\end{abstract}

Não estamos acostumados a refletir sobre nossa própria língua e, por isso, situações de preconceito passam despercebidas no dia a dia. O interesse em fazer uma pesquisa centrada nas estratégias cognitivas utilizadas para construir o discurso surgiu a partir das aulas de Morfossintaxe Contrastiva de Línguas Modernas na Universidade de Brasília, ministradas pelo prof. Dioney M. Gomes. Perceber como a língua reflete nossos objetivos comunicacionais me levou a questionar como tais estratégias perpassam nossas práticas sociais. Além disso, durante a graduação, pude perceber o pouco espaço que as comunidades indígenas ocupam no meio acadêmico. Não existe um grande número de textos que procurem dar real e valoroso destaque a essas comunidades. Atualmente, portanto, me questiono quais estratégias, por exemplo de alteração de voz e/ou de valência, são usadas para falar sobre os indígenas em discursos de grande alcance como o da mídia.

Existe, no Brasil, um preconceito acentuado contra os povos indígenas. No exemplo que será dado na seção 6 , notamos a representação estereotipada que já é bem difundida em nossa sociedade: o indígena não gosta de trabalhar, impede que outros o façam e exige seus direitos através de ocupações e atos de vandalismo. É fato que existe imperícia dos leitores em identificar as estratégias linguísticas usadas pelos jornais para veicular sua ideologia contra o indígena. Essa imperícia é fruto de uma escolarização que, via de regra, ainda é incapaz de formar leitores críticos em nossa sociedade. 
Devemos levar em consideração também que as leituras são sempre projetadas; o leitor tem sempre pré-construída uma linha de sentido que seguirá durante a leitura. Isso só acontece porque "quem lê um texto, lê a partir de determinadas expectativas e na perspectiva de um sentido determinado" (GADAMER, 2005 p.356). A afirmação do filósofo vai ao encontro do que prega a Linguística Cognitiva: um sentido central, normalmente, passa a se estender para novos sentidos que se aproximam dele.

Segundo Duque e Costa (2012), são os processos cognitivos e criativos que nos possibilitam organizar e transformar nossas experiências em linguagem. Tais experiências não são mera representação da realidade, e sim, uma interpretação baseada em modelos socioculturais evocados pelo sujeito. Assim, quando produzimos um texto, dependemos diretamente desses modelos evocados de situações concretas de uso da linguagem. Os discursos cotidianos que lemos nos jornais exaustivamente servirão como modelo para que façamos a categorização de uma comunidade indígena, por exemplo. Construiremos uma essência sobre essa comunidade e atribuiremos sentidos próximos em discursos futuros. Nossas escolhas linguísticas estarão intimamente ligadas a esses processos cognitivos.

Assim, esta pesquisa pretende colocar em evidência tais estratégias, partindo da análise linguística dos textos jornalísticos. Isso também será importante para a descrição do português culto, para a análise do discurso oficial sobre os povos indígenas e para uma possível mudança de postura sobre eles.

Como veremos a seguir, os poucos, mas importantes trabalhos que existem sobre essa temática, procuram questionar a visibilidade de grupos minoritários como os indígenas. Até agora, no entanto, não encontramos nenhuma análise como a funcionalista que pretendemos aqui fazer.

Um dos trabalhos relevantes sobre a temática "índios e mídia" é a dissertação de mestrado de Melo (2003). Segundo ela, a mídia é legitimada pela sociedade por ter a função de representar determinados segmentos sociais. E, assim como ela, em nosso trabalho nos baseamos na hipótese de que grupos minoritários como os indígenas têm pouca ou nenhuma influência sobre a mídia e normalmente são excluídos, silenciados ou “selvagizados" por ela.

Melo (2003) trabalha com os critérios de noticiabilidade. A imprensa, normalmente, segue esses critérios para escolher os assuntos mais relevantes e o que deve ou não ser publicado. O jornal diário é, para ela, não a realidade em que vivemos, mas sim a representação dessa realidade, não havendo, portanto, uma quebra dos estigmas existentes. 
A autora faz uma análise de 23 notícias veiculadas no Diário de Pernambuco e no Jornal do Commercio, amplamente difundido em Pernambuco. Melo (2003) usa como método de análise para essas notícias os conceitos de fonte ativa e passiva, além da Análise do Discurso de linha francesa. Dessa forma, a autora utiliza a definição de Marcuschi (1991) de verbos introdutórios de opinião, o uso de aspas definido por Authier-Revuz (1990) e Maingueneau (2002), além do conceito de heterogeneidades discursivas de Authier-Revuz (1990). A partir das análises, a autora conclui que qualquer discurso tem consequências sobre o imaginário social. Sobre o discurso indígena, reforça que "ao contrário do que imaginou inicialmente Harbermas (1998), o sujeito não se despe de sua condição social para ingressar na esfera pública. Ele fala a partir deste lugar - com todo ônus ou vantagem que possa acarretar ao seu discurso" (MELO, 2003, p.184).

Para o indígena, esse lugar social ainda não mudou. É de um não-brasileiro, que tem sido, na mídia, relacionado à violência. Um papel ainda subalterno, submisso e silenciado, construído ao longo dos tempos. As questões ligadas à saúde, cultura e educação indígena são raramente postas em pauta pela mídia e menos ainda de maneira isenta, crítica e construtiva.

Os resultados da pesquisa de Melo (2003) coincidem com os da pesquisa de Neves \& Silva (2013), que trabalham com uma Análise discursiva e da imagem dos indígenas que foram veiculados no jornal O Liberal nos anos de 1990 e 2011. Nele, as autoras afirmam que o leitor dos jornais ainda enxerga o índio como um problema social. A saúde indígena e o conflito de terras ocupam lugares de destaque na mídia, e existe ainda a ausência de reportagens que mostrem a singularidade da cultura e história dessas sociedades. O silenciamento do discurso desses povos é reforçado e inventa o índio genérico, que precisa ser civilizado - do contrário, causará problemas de desenvolvimento para o país (cf. novamente exemplo dado na subseção 0.6 e o capítulo 4).

Em 2011, ainda segundo Neves \& Silva (2013), com o advento de imagens coloridas, nota-se um maior número de reportagens referentes à cultura indígena; o foco, entretanto, é nos protestos contra a construção da Hidrelétrica de Belo Monte. Até mesmo no Dia do Índio, ao contrário da reportagem analisada pelas autoras nos anos 90, em que se veiculou uma matéria de cunho histórico, tem-se nesse ano uma matéria especial em comemoração ao Dia do Índio contra a construção de Belo Monte. A análise feita da imagem mostrava uma índia com cocar na cabeça e a mão em punho, como se estivesse indo para a guerra. Considerando a data comemorativa, as autoras esperavam que fosse veiculada uma matéria que abordasse aspectos culturais e não os problemas da comunidade indígena. Em resumo, as análises mostram que os 
jornais ajudam a construir uma identidade estereotipada das populações indígenas, mesmo estando o jornal $O$ Liberal situado no estado com o maior número de povos indígenas, o estado do Pará.

Sobre a identidade indígena estereotipada e inventada, Neves (2009, p.18) afirma que:

\begin{abstract}
A invenção do índio implica pelo menos dois sentidos para o uso da palavra invenção. Podemos entender que se trata de uma falsificação forjada pelas relações de poder do sistema colonial, que institui um índio genérico, antropófago, sem roupa, sem conhecimento e de mentalidade primitiva. [...] Acredito mesmo que os índios, quando foi possível resistiram e ainda hoje, apesar das inúmeras dificuldades que enfrentam, continuam reinventando suas tradições e demarcando suas novas fronteiras culturais. Neste sentido mais construtivo, a invenção é um exercício de criatividade das sociedades indígenas.
\end{abstract}

Inferimos da citação acima que a identidade indígena é construída de forma a massificar os povos e mantê-los, como dito por Melo (2003), em uma posição subalterna. A representação que ainda paira sobre o imaginário coletivo é de um povo indígena (como se fosse um só mesmo!) que não sofreu transformações ou evoluiu.

Sobre isso, Silva (2010, p.75) lembra que

\begin{abstract}
Além de serem interdependentes, identidade e diferença partilham uma importante característica: elas são o resultado de atos de criação linguística. Dizer que são o resultado de atos de criação significa dizer que não são 'elementos' da natureza, que não são essências, que não são coisas que estejam simplesmente aí, à espera de serem reveladas ou descobertas, respeitadas ou toleradas. A identidade e a diferença têm que ser ativamente produzidas. Elas não são criaturas do mundo natural ou de um mundo transcendental, mas do mundo cultural e social [e linguístico].
\end{abstract}

Desse modo, as relações sociais, culturais e, para nós, também linguísticas moldam tanto a identidade quanto a diferença. A língua, como meio de dar nome às coisas que nos cercam e predicar sobre elas, exerce a função imprescindível de instituir a diferença e a identidade como tais.

Para discutir identidade, vejamos o que nos diz o trabalho feito por Gregolin (2007), intitulado Análise do discurso e mídia: a (re)produção de identidades. Nele, a autora procura analisar como as imagens veiculadas nos meios de comunicação podem reproduzir identidades que são construídas no imaginário coletivo. Além disso, a autora demonstra como essas imagens são reforçadas pelas legendas que as acompanham. Isso será abordado em nosso capítulo teórico.

Em sua pesquisa, Del’Vigna (1995, p. 17) também encontra, na mídia escrita, a concepção das comunidades indígenas como um atraso para o desenvolvimento do país: 
“Ao analisar o discurso sobre o índio na imprensa escrita, constata-se que ele é desfavorável ao índio. Em quase todos os textos, observa-se a defesa dos interesses dos poderosos em nome do desenvolvimento e do bem-estar da população brasileira". Segundo a autora, a linguagem é usada pelo falante para direcionar as ações do ouvinte para um contexto em particular, influenciando seu comportamento. A mídia serve, portanto, como mediadora da realidade e da construção de representações pelos leitores para manter uma relação de poder. Essa relação só é mantida porque quem está no poder tende a silenciar grupos menores ou opositores para que eles não consigam se integrar à sociedade, atendendo, assim, aos interesses de uma classe dominante.

Orlandi (1988, p. 1l) reforça essa ideia ao afirmar que: "Quando se lê, considera-se não apenas o que está dito, mas também o que está implícito: aquilo que não está dito e que também está significando".

Apesar de já existirem trabalhos com a temática mídia e o indígena brasileiro, ainda existem algumas lacunas sobre a temática que são de extrema importância para compreendermos por que a representação negativa sobre os grupos indígenas brasileiros persiste na percepção social, mesmo que haja uma luta desses grupos para continuar existindo e uma tentativa de reinvenção constante.

Tendo em vista que os estudos funcionalistas não consideram a sintaxe como uma entidade autônoma e que, via de regra, as estruturas estão a serviço de um contexto pragmáticodiscursivo, entendemos como relevante um estudo sobre como as estruturas linguísticas têm sido manipuladas no discurso jornalístico para se referir às comunidades indígenas. Esse é o nosso rumo aqui.

\subsection{Introdução ao referencial teórico}

Primeiramente, é necessário esclarecer que, neste trabalho, tratamos o processo de compreensão do texto a partir da perspectiva de uma corrente funcionalista chamada Linguística Centrada no Uso ou Cognitivo-Funcional. Essa corrente é soma de estudos de Linguística Cognitiva com Tipológicos-funcionais. Este último surgiu na Costa-Oeste dos Estados Unidos na década de 1970 com trabalhos de pesquisadores, como Givón, Thompson, Chafe, Hopper. Tais estudiosos entendiam a forma da língua como sendo determinada pela função e não o oposto. Essa perspectiva é adotada ao longo de nosso trabalho. Também adotamos trabalhos da Linguística Cognitiva (Langacker 1987; Lakoff, 1987) entre outros. 
Além da retratação dos povos indígenas só ocorrer em situações específicas, as estruturas linguísticas utilizadas para noticiá-la/difundi-la influenciam no modo como enxergamos e julgamos esses povos. Vista sob uma perspectiva funcionalista, sabe-se que as estruturas gramaticais da língua não são escolhidas ao acaso - essas escolhas dependem do contexto de uso. Conforme proposto por Halliday (apud CUNHA 2010, p. 159), a semântica e a pragmática devem ser incorporadas à análise sintática. afirma:

Sobre voz verbal, um construto relevante em nossas análises, Camacho (2000, p. 216)

\begin{abstract}
Ser [ela] um conceito multifatorial, [o que] significa que a voz verbal representa um grande número de valores e de possibilidades correspondentes de expressão que, segundo Givón (1981, 1994), envolvem três domínios funcionais: a) topicalidade: atribui-se a função de Tópico a um argumento não-Agente; esse comportamento é oposto ao da sentença ativa correspondente, em que o Tópico é comumente o Sujeito/Agente; b) impessoalidade: suprime-se a identidade/presença do argumento Agente, geralmente o Sujeito expresso da sentença ativa; c) detransitividade: a construção de voz é semanticamente menos "ativa", menos transitiva, mais estativa que a construção "ativa" correspondente.
\end{abstract}

Schnoebelen (2008, p.02) estabelece ainda que:

\begin{abstract}
Voz, na definição de Payne, (ver Payne 1997:213) só acontece quando há opções. O falante (inconscientemente) avalia qual participante é mais tópico. Assim, ao menos alguns sistemas inversos são voz, passivas sempre são voz, médias podem ser pensadas como voz também. A única diferença entre a função de uma passiva e de uma construção média é que a passiva trata a situação como uma ação praticada por um agente, mas com a identidade do agente subestimada. Uma construção média, por outro lado, trata a situação como um processo, ou seja, ignora o papel do agente (Tradução nossa). ${ }^{2}$
\end{abstract}

Das ideias acima, destaca-se o fato de a voz ter um caráter opcional. Se duas estruturas são concorrentes sobre um assunto, o que leva à escolha de uma e não de outra? Payne (2006, p.237) lembra que a voz verbal, prototipicamente, alinha as relações gramaticais sujeito e objeto respectivamente com os papéis semânticos agente e paciente, e com os papéis pragmáticos tópico e foco. Assim, tanto no Português quanto no Inglês, um sujeito prototípico é o agente e

\footnotetext{
${ }^{2}$ Voice, by Payne's definition (see, for example Payne 1997: 213), only happens when there's an optionality. The speaker (unconsciously) assesses which participant is more topical. Thus at least some inverse systems are voices, passives are always voices, middles can be thought of as a voice, too. The only difference between the function of a passive and the function of a middle construction is that a passive treats the situation as an action carried out by an agent but with the identity of the agent downplayed. A middle construction, on the other hand, treats the situation as a process, i.e., it ignores the role of the agent. (SCHNOEBELEN, 2008, p.02)
} 
o tópico na voz ativa. Já na voz passiva, é o paciente que surge como sujeito, sendo topicalizado. Segundo Givón (2013, p.16) "nossa gramática e nosso léxico refletem - e são moldados por uma visão construída de nosso universo". Assim, devemos ter em mente que tanto a estrutura como a maneira em que a língua é codificada refletem um conteúdo proposicional, que carece de uma compreensão linguística por parte do leitor/ouvinte para que seja corretamente depreendida.

Sobre valência, outro construto relevante em nossa pesquisa, Payne (2006) defende que ela é composta por Valência Semântica - o número de participantes selecionados pelo verbo no cenário discursivo, e Valência Gramatical ou Sintática, que se refere ao número de argumentos presentes em uma oração. Borba (1990, p.21) define valência como "o conjunto de relações estabelecidas entre o verbo e seus constituintes indispensáveis". Assim, podemos pensar que algumas vezes esses constituintes indispensáveis estão explícitos no texto e, outras vezes, eles são evocados por nosso conhecimento de mundo.

A metáfora do palco utilizada por Lakoff (1987) ainda é uma das mais didáticas para elucidar o conceito de valência. As construções linguísticas formam diferentes quadros mentais. Isso depende de como a mente categorizou, armazenou e ajustou o conhecimento e o sistema linguístico a depender do contexto. As construções ativas trazem, normalmente, todos os participantes para o centro do palco, ficando o sujeito/agente (ator principal) em primeiro plano frente ao objeto/paciente em segundo. Enquanto isso, as operações de diminuição de valência (passivas, recíprocas, médias, etc.) passam um "ator principal" para um papel periférico ou eliminam sua participação na cena discursiva e fazem o inverso com um "ator secundário". As operações de aumento de valência (como causativas, aplicativas e subida do possuidor), por sua vez, trazem para a cena um ator que não estava previsto no roteiro, via de regra diminuindo a importância de outro ator já presente no palco. Assim, entendemos que a língua serve de instrumento para que o falante construa com seu interlocutor determinada cena discursiva e não outra, produza determinadas representações e não outras. Abordaremos de maneira mais profunda esses conceitos no capítulo 1 e veremos sua aplicação no capítulo 4 .

Os conceitos de Voz e Valência são de suma importância quando pensamos nas possíveis inferências que o leitor de um jornal vai ter que fazer ao se deparar com uma reportagem com a temática indígena. Segundo Kleiman (2003), é o conhecimento prévio que um leitor tem acerca do assunto abordado que lhe permitirá fazer determinadas inferências e compreender o texto como um todo. Kleiman (2003, p.13) lembra, também, que a compreensão de um texto não é uma tarefa simples, pois envolve "uma rede de relações sintáticas, lexicais, 
semânticas, pragmáticas, a nível de sentença, período, parágrafo, relações estas que tornam o objeto rico demais para uma percepção rápida, imediata e total”.

A partir dessa análise, ponderamos e avaliamos, no capítulo 2, se estas estruturas contribuem para a formação de uma representação positiva ou negativa das comunidades indígenas. Caso essa representação esteja sendo construída de forma negativa, discutimos se há identificação com o que van Dijk (2003, p.40) chama de "racismo do dia a dia", que acontece com grupos minoritários de determinada sociedade e acaba se tornando um sistema de estresse psicológico e social, quando não, opressão. Segundo o autor, esse preconceito se naturalizou e não causa nenhum incômodo ao grupo dominante, como ocorre com o racismo contra outros grupos étnicos mais proeminentes na sociedade.

Fazemos, nesta dissertação também, a análise de alguns pontos linguísticos que, segundo van Dijk (2003), influenciam nas organizações das estruturas enunciativas e do entendimento de tais estruturas pelo receptor da mensagem. O autor cita, por exemplo, a topicalização de informações em manchetes de jornais para construir um julgamento a respeito do que se quer notíciar. Aí, então, cruzamos com o conceito de tópico/topicalização da linguística Funcional-Cognitiva. Outro ponto importante levantado por van Dijk é a cautela necessária ao analisarmos elementos implícitos e explícitos em um texto. Normalmente, ressaltam-se pontos negativos de grupos contrários aos grupos dominantes. E tentamos responder à pergunta de como, estruturalmente, isso ocorre.

Tratamos as notícias como um evento discursivo, pois é por meio dela que os membros de determinada comunidade trocam valores e constroem significados para o próprio mundo. A notícia alimenta crenças e ideias. Hall (1980) trata a notícia como a tradução de pontos de vista oficiais para um idioma público ${ }^{3}$. Mota $(2012$, p.208) afirma que a narrativa jornalística "vai tomando forma até se transformar numa versão de um fato, numa notícia com a sua carga de assertividade e de intenção de verdade". Assim, inferimos que a notícia é uma articulação discursiva sobre um fato e não a representação imparcial dele.

Para a análise de critérios de noticiabilidade, nos pautamos no quadro de Silva (2008a, p. 102), denominado de "Elenco de valores-notícias", particularmente nos critérios de Wolf e nos critérios de Bond (ver capítulo 2).

Escolhemos os critérios adotados por Wolf e os adotados por Bond destacados acima por tratarem de questões de interesse nacional, injustiças que provocam indignação e a

\footnotetext{
${ }^{3}$ Entende-se aqui "idioma público" como uma linguagem acessível ao leitor. Portanto, o jornalista deve tomar os depoimentos, declarações, etc. e parafraseá-los com uma linguagem acessível ao grande público.
} 
importância que o indivíduo envolvido na notícia tem na sociedade. Acreditamos que tais critérios refletem nas escolhas das estruturas verbais que farão parte das manchetes e das notícias, além de serem, possivelmente, os critérios que melhor abarcam as questões indígenas na mídia nacional. Aprofundaremos os referenciais teóricos nos capítulos 1 e 2.

\subsection{Introdução à metodologia}

Tendo em vista o arcabouço teórico supracitado, fazemos uma análise predominantemente qualitativa e sincrônica dos dados, com o intuito de avaliar como as estruturas escolhidas pela mídia para tratar de assuntos indígenas podem ou não reforçar uma representação estereotipada dessa minoria.

Combinamos diferentes pontos de vista teóricos para lidar com o objeto de pesquisa, a saber: o funcionalismo cognitivo-funcional, que foi enriquecido pelos estudos do discurso de van Dijk (2003), além, é claro, do necessário suporte do Jornalismo enquanto campo teórico e metodológico. Entraremos em mais detalhes sobre a metodologia no capítulo3, porém, em resumo, a metodologia seguiria a seguinte perspectiva:

Na prática, para a execução desta proposta, definimos:

1) Selecionar e analisar reportagens que apresentem como temática principal os povos indígenas, compreendidas nos anos de 2012/2013/2014 e janeiro de 2015 e veiculadas na Folha de SP e no G1 em seus respectivos portais. A escolha desses jornais se deve ao seu amplo alcance nacional. Serão levantadas as estruturas linguísticas presentes e identificadas as estratégias de mudança de voz e valência; foram analisadas relações gramaticais e os papéis semânticos e pragmáticos; foram analisadas reportagens escritas e apenas a linguagem verbal;

2) Aplicar os conceitos/construtos presentes em van Dijk (2003) e ponderar se as estruturas identificadas nos jornais analisados contribuiriam efetivamente para a formação de uma representação positiva ou negativa das comunidades indígenas brasileiras; aqui ocorrerá a aproximação entre o referencial teórico funcional-cognitivo e o referencial teórico dos Estudos Críticos do Discurso, em uma clara tentativa de associar recursos teóricos de correntes linguísticas próximas e maximizar o valor dos resultados aferidos;

3) Avaliar, também, os possíveis critérios de noticiabilidade adotados nas notícias, a partir dos temas escolhidos pela imprensa sobre os indígenas para serem notíciados. Também verificamos em que medida esses critérios de noticiabilidade se assentam em questões linguístico-discursivas. Também avaliamos a estrutura da notícia. 
Para essa leitura, estabelecemos um protocolo de análise, que será apresentado no capítulo 3 e aplicado no capítulo 4.

A seguir, apresentamos uma análise piloto

\subsection{Análise Piloto}

Levando em consideração o aporte teórico supracitado, elaboramos a análise piloto da notícia mostrada a seguir, em que começamos a verificar como as estruturas de voz e valência estão sendo utilizadas para obter/manipular a atenção do leitor.

Quadro 1 - Exemplo de notícia sobre povos indígenas brasileiros

Índios mantêm ocupação em prédio da Funai em Brasília

Grupo dormiu no prédio nesta madrugada e quer reunião com governo.

Para Gilberto Carvalho, governo terá uma 'teimosa posição de diálogo'.

Cerca de 150 indígenas da etnia Munduruku passaram a noite desta segunda-feira (10) no prédio da Fundação Nacional do Índio (Funai), em Brasília. A ocupação, que continua nesta terça-feira (11), fez que funcionários do órgão não fossem trabalhar, segundo informações da segurança do prédio.

(...)

A Funai informou que tem uma equipe de diálogo conversando com as lideranças Munduruku a fim de resolver pacificamente a questão.

O grupo de índios chegou a Brasília na terça-feira da semana passada em dois aviões da Força Aérea Brasileira para se reunirem com o ministro da Secretaria-Geral da Presidência, Gilberto Carvalho. Eles entraram em divergência com o ministro ao ouvirem que, mesmo após consulta pública, o governo não pretende interromper a construção das usinas.

(fonte: MENDES, Priscila. Índios mantêm ocupação em prédio da Funai em Brasília. G1, 2013. Disponível em: <http://g1.globo.com/distrito-federal/notícia/2013/06/indios-mantem-ocupacao-empredio-da-funai-em-brasilia.html > acesso em 28/10/2013.)

Nesse exemplo, nota-se na manchete o uso genérico de "índios", embora saibamos que existam mais de 200 etnias no Brasil. O termo aí é utilizado no plural, criando um sentido de massificação, tomando como um todo os povos indígenas. A etnia é especificada apenas no corpo da matéria. Segundo van Djik (2004), a generalização na mídia de um determinado grupo social como causador de efeitos negativos na sociedade pressupõe que políticas públicas devam 
ser adotadas para controlá-los, mesmo que não seja o caso de "falta de controle". Assim, generalizar a comunidade indígena como um grupo que tende a ocupar espaços públicos sugere que é urgente fazer algo contra esse grupo, caracterizado implicitamente como "selvagens precisando de civilização". A função sintática do termo "índios" é de sujeito, com leitura semântica de agente, e o verbo tem valor negativo, além de exigir um agente que tenha controle sobre suas ações e com traço mais humano. A ocupação, aqui com função sintática de objeto, denota que os índios estão invadindo um espaço que não lhes pertence, uma vez que "ocupação" tem como sinônimos "apoderamento" e "invasão". O uso da locução adverbial no fim da frase mostra que, além de terem ocupado um prédio que pertence a outra pessoa, o fizeram na capital do país, em um cenário fortemente político. O uso do nome do ministro-chefe da SecretariaGeral da Presidência da República, no lead da matéria, tem o poder de reforçar a ideia de que a ocupação tem grande influência no cenário político. Ainda no lead da notícia, podemos inferir que o grupo indígena é resistente à negociação e violento, e que, por isso, o governo tem de insistir em assumir uma "teimosa posição de diálogo". O próprio emprego do verbo no futuro implica uma previsão, por parte do jornal, de que os indígenas não serão pacíficos e não concordarão em dialogar com o governo, que terá de resistir e insistir em uma posição diplomática.

Já no texto, observamos o uso de uma causativa perifrástica em fez que funcionários do órgão não fossem trabalhar, tornando a ocupação indígena um superagente que exerce controle sobre os funcionários da Funai e os impede de trabalhar. Os funcionários passam a ser vítimas dos índios e perdem sua capacidade de agir, sua volição, sendo impedidos de trabalhar. Cumpre lembrar que a causativa perifrástica traz à cena discursiva um argumento que, prototipicamente, não é exigido pelo verbo. É uma estratégia de mudança de voz para trazer um superagente controlador que direciona as ações de um outro sujeito, cuja agentividade é diminuída.

Percebemos nessa matéria uma estratégia básica de discurso ideológico apontada por van Djik (2003, p.44): "Enfatizar pontos positivos sobre Nós. Enfatizar pontos negativos sobre Eles. Não-enfatizar pontos negativos sobre Nós. Não-enfatizar pontos positivos sobre Eles.” (tradução nossa). ${ }^{4}$

Como dito anteriormente, na reportagem enfatiza-se o fato de que os índios estão ocupando uma propriedade que não lhes pertence e estão, também, impedindo que funcionários

\footnotetext{
4 "Emphasize positive things about Us. Emphasize negative things about Them. De-emphasize negative things about Us. De-emphasize positive things about Them" (VAN DJIK, 2003, p.44)
} 
trabalhem. Por outro lado, a causa da ocupação só é mencionada no final da reportagem, com um uso de um verbo que modaliza a ação do governo. Ele não pretende parar a construção de usinas, mas a certeza não é dada. Evoca-se a instituição da segurança para ser a fonte da informação, conferindo maior veracidade aos fatos.

O que se ressalta sobre o governo na matéria é a tentativa de um diálogo para que haja a desocupação do prédio, destancando-se, assim, apenas as ações positivas do chamado "homem branco" e os transtornos causados à sociedade pelos indígenas. Não é só um transtorno causado pela ocupação, mas também essa resistência ao avanço e desenvolvimento do país que se teria com a construção de novas usinas. Não se questionam, porém, os motivos reais que levam os indígenas a lutarem para que essas construções sejam paradas. Notamos, portanto, a ausência da voz das lideranças indígenas.

Esse estudo piloto norteou a presente pesquisa e serviu de base para criamos um protocolo de análise textual, que detalha os pontos acima levantados e introduz outros igualmente relevantes (cf. capítulo 3 e 4 ).

Esta dissertação é composta de 5 capítulos. Os capítulos 1 e 2 delimitam o escopo teórico. O capítulo 3 é dedicado ao fazer metodológico. O capítulo 4 traz as análises empreendidas e os resultados. E o capítulo 5 apresenta as considerações finais da dissertação. 


\section{Capítulo 1 - Linguística Funcional Centrada no Uso ou Cognitivo-Funcional}

\subsection{Introdução}

Nossa pesquisa tem suporte teórico no funcionalismo-tipológico (GIVÓN (1994, 1995, 2001); HOPPER E THOMPSON (1980); DELANCEY (2001); PAYNE (1997, 2011), COMRIE (1989), SHIBATANI (1985), DIXON \& AIKHENVALD (2000); NEVES (2004), entre outros). Aliamos tal enfoque aos estudos cognitivistas, formando o que se tem chamado de Linguística (Funcional) Centrada no Uso (BYBEE (2010), LAKOFF (1997,1987), LANGACKER (1987), LAKOFF \& JOHNSON (2008), TOMASELLO (2009), FURTADO DA CUNHA (2010), MARTELOTTA (2010, 2011). Nesse quadro, a língua é compreendida como um instrumento de comunicação e interação social, pragmaticamente motivada e constituída.

Este capítulo está dividido em 3 seções. Na seção 1.1., abordaremos a Linguística Funcional Centrada No Uso (ou Linguística Cognitivo-Funcional). Na seção 1.2., apresentaremos os construtos norteadores deste trabalho no que diz respeito ao Funcionalismo Tipológico. Por fim, na seção 1.3, apontaremos os principais construtos da Linguística Cognitivista que servirão de base para nossas análises.

\subsection{Linguística Funcional Centrada no Uso (Usage-based Linguistics) ou}

\section{Linguística Cognitivo-Funcional}

O funcionalismo em Linguística rejeita a autonomia da estrutura e entende que há uma ligação, ainda que instável, da forma com a função. O dinamismo é essencial, uma vez que se estudam os componentes linguísticos em seus usos reais. De acordo com Dik (1978), a linguagem é, em primeiro lugar, um instrumento para interação social, usada com a finalidade de uma cooperação social. Na interação, o enunciador faz uso das estruturas linguísticas que julga, inconscientemente ou não, mais adequadas para provocar determinados efeitos sobre seu interlocutor. Assim, só faz sentido para uma abordagem funcionalista estudar a língua socialmente situada.

Segundo Castilho (2012, p. 19),

(...) o formalismo e o funcionalismo se distinguem na estratégia de abordagem do fenômeno linguístico, e no papel conferido à gramática, à semântica, e ao discurso, entendidos tacitamente como módulos da linguagem. (...) $\mathrm{O}$ funcionalismo contextualiza a língua na situação social em que se dá a interação verbal, cujas representações estruturais são estudadas. 
A linguística funcional norte-americana começa a ganhar projeção na década de 1970, a partir dos estudos tipológicos e de universais linguísticos. A corrente funcionalista entende a língua como algo que está a serviço dos seus usuários, dos contextos de interação, das intenções e recortes cultural e socialmente marcados. Para o funcionalismo, a língua deve ser analisada levando em consideração o contexto linguístico e a situação extralinguística. Portanto, discurso e gramática não podem ser pensados como entidades desvinculadas, visto que se influenciam e se determinam mutuamente. A esse respeito, Dik (1997, p. 4) afirma que

\begin{abstract}
Uma teoria linguística não deve apenas apresentar as regras e princípios subjacentes à construção da expressão linguística, limitando-se a eles mesmos a teoria; mas deve tentar, sempre que possível, explicar essas regras e princípios, levando em conta também sua funcionalidade com respeito aos usos reais de tais expressões. (tradução nossa $)^{5}$
\end{abstract}

Indo ao encontro da ideia apresentada por Dik, DeLancey (2001) postula que determinadas estruturas atendem a determinadas funções, assim como determinadas funções se adequam a determinadas estruturas. A língua, portanto, se molda ao discurso. A própria sintaxe é uma estrutura em constante mudança para alcançar tal adaptação. Assim, estudar as operações de mudança, diminuição e aumento de voz e valência, sob uma perspectiva funcionalista, implica analisar não só a estrutura pela estrutura, mas o contexto linguístico interno ao texto e o extralinguístico, que fazem com que essas mudanças se tornem necessárias, possíveis e desejáveis.

Neves (2004, p.15-17), citando Halliday, afirma que "o enunciado não parte de uma estrutura profunda abstrata, mas das escolhas que o falante faz quando o compõe para um propósito específico, com elas produzindo significado". A autora lembra ainda a máxima de Coseriu "de que no uso linguístico há o exercício da capacidade de falar (a linguagem), num falar historicamente inserido (numa dada língua) e num evento particular".

Essa perspectiva funcionalista será de suma importância no decorrer deste trabalho, pois só se justifica o estudo do discurso midiático sobre os indígenas brasileiros, se partirmos do pressuposto de que existem escolhas a serem feitas na maneira de se construir um enunciado.

\footnotetext{
${ }^{5} \mathrm{~A}$ theory of language should not be content to display the rules and principles underlying the construction of linguistic expression for their own sake, but should try, wherever this is possible at all, to explain these rules and principles in terms of their functionality with respect to the ways in which these expressions are used. (DIK, 1997, p. 4)
} 
A linguística cognitiva, por sua vez, surge, também, na década de 1970, e tem como objeto de estudo a relação entre a linguagem e a experiência humana. Para essa corrente, tanto o conhecimento linguístico quanto o não linguístico se dão da mesma forma. A língua não é vista como uma entidade autônoma e autossuficiente. Há, então, uma relação entre a linguagem, o pensamento e a experiência. Como linguagem, adota o conceito de Tomasello (2009) que afirma ser a linguagem um complexo mosaico de atividades cognitivas e sociocomunicativas ligadas à psicologia humana.

Bybee (2010) postula que a linguística centrada no uso deve pensar na gramática como a organização cognitiva da experiência por meio da linguagem. Segundo a autora (2010, p.10),

\begin{abstract}
Em uma teoria centrada no uso, na qual a gramática se baseia diretamente na experiência, não há dados que não sejam levados em consideração, mesmo aqueles oriundos do desempenho e não da competência. (...) Levamos em conta os diferentes fatores que operaram em cada um dos contextos nos quais os dados surgem. ${ }^{6}$ (Tradução nossa)
\end{abstract}

Assim, o cognitivismo inova ao colocar o usuário como centro da construção de significado e condiz com a abordagem funcionalista ao analisar situações reais de uso. Martelotta (2010, p. 181) declara que "para os cognitivistas, a comunicação é uma atividade compartilhada, ou seja, implica uma série de movimentos feitos em conjunto pelos interlocutores em direção à compreensão mútua”.

Outro conceito de extrema relevância desenvolvido pelos cognitivistas é o do pensamento corporificado. De acordo com Martelotta \& Palomanes (2010, p. 181),

Nosso primeiro contato com o mundo se dá através dos nossos sentidos corporais, e a partir daí algumas extensões de sentido são estabelecidas. Segundo esse ponto de vista, nossa estrutura corporal é extremamente importante, já que a percepção que temos do mundo é limitada por nossas características físicas.

Entende-se que corpo e mente não podem ser separados. Assim, a estrutura da nossa mente é moldada e limitada segundo parâmetros físicos. Um bom exemplo disso é a nossa

\footnotetext{
${ }^{6}$ In usage-based theory, where grammar is directly based on linguistic experience, there are no types of data that are excluded from consideration because they are considered to represent performance rather than competence. (...) we understand the different factors operating in each of the settings that give rise to the data. (BYBEE, 2010, p.10)
} 
expressão de tempo que faz uso de noções espaciais como "alguns anos atrás" e "daqui pra frente".

Assim, uma análise Cognitivo-Funcional (Linguística Funcional Centrada no Uso) tem como princípio básico o fato de que a estrutura da língua se origina no uso. Há uma aparente regularidade que convive com uma instabilidade; ambas são motivadas e modeladas pelos usuários em suas práticas discursivas no cotidiano.

Por levar em conta essa correlação entre linguagem e experiência, a Linguística Funcional Centrada no Uso (doravante LFCU) busca não só os padrões linguísticos, como também as motivações das estruturas, tanto no discurso e na pragmática quanto na semântica e na cognição.

Por cognição, a LFCU entende o processo em que se constrói o conhecimento a partir da interação do organismo com o meio. O meio aqui abrange não só o espaço físico como também o ambiente sociocultural em que o individuo está inserido. Os conceitos do cognitivismo, por exemplo, categorização, protótipo e metáforas, serão de fundamental importância em nosso estudo e serão abordados na seção 1.3.

Furtado da Cunha, Bispo \& Silva (2013, p. 9) explicam que a LFCU

\footnotetext{
parte do princípio de que há uma simbiose entre discurso e gramática: o discurso e a gramática interagem e se influenciam mutuamente. A gramática é compreendida como uma estrutura em constante mutação/adaptação, em consequência das vicissitudes do discurso. Logo, a análise de fenômenos linguísticos deve estar baseada no uso da língua em situação concreta de comunicação.
}

O que se propõe aqui, portanto, é uma análise das estruturas mais recorrentes nos textos midiáticos sobre o indígena brasileiro, de modo que possamos explicitar quais estratégias estão sendo utilizadas e em que contexto elas ocorrem.

A seguir, abordaremos construtos essenciais para o desenvolvimento desta pesquisa.

\subsection{Construtos do Funcionalismo Tipológico}

Nesta subseção, falaremos de relações gramaticais, papéis semânticos, papéis pragmáticos; trataremos do conceito de voz e valência; e mostraremos as principais estratégias que as línguas usam para reduzir, aumentar ou rearranjar valência, atendendo a anseios discursivos. Esses construtos entraram em nossa análise dos dados e fundamentam muitas de nossas considerações sobre o tema desta pesquisa. 


\subsubsection{Relações gramaticais}

Segundo Payne (2011, p. 169), as relações gramaticais são funções sintáticas de elementos nominais nos enunciados. As relações gramaticais (doravante RG) são, portanto, relações entre argumento e predicado, que não estão obrigatoriamente vinculadas a determinados papéis semânticos e pragmáticos (como apresentaremos nos próximos tópicos). Uma mesma RG pode estar sendo representada por diferentes papéis semânticos, assim como, um mesmo papel semântico pode expressar-se por meio de diferentes RGs.

As relações gramaticais mais comuns são sujeito, objeto direto, objeto indireto, ergativo e absolutivo, segundo Payne (1997, p.129). Usamos o termo oblíquo (ou adjunto) para nos referir a um nome que não mantém uma relação gramatical com o predicado. Ainda de acordo com o autor, as relações gramaticais podem ser expressas por meio de caso morfológico, morfologia verbal e/ou ordem dos constituintes. Nas situações comunicacionais do dia a dia, é de suma importância que se faça a distinção entre quem é sujeito e quem é objeto. Só assim nosso ouvinte consegue fazer a distinção entre quem é o afetado e quem é aquele que age. Por exemplo:

(1) Pedro quebrou o vaso.

No enunciado (1), identificamos rapidamente que Pedro é o sujeito e que ele exerceu uma ação que modificou o estado do vaso, que agora se encontra quebrado. Pedro vem em uma posição pré-verbal (típica de sujeito em Português) e controla a morfologia do verbo (se o enunciado tivesse um sujeito no plural, a morfologia do verbo mudaria: Pedro e Rafael quebraram o vaso). O vaso, como se encontra em uma posição pós-verbal (típica de complemento objeto), é afetado e não controla a morfologia do verbo, sendo classificado como objeto direto.

Com relação às análises gramaticais, Keenan (1975) nos diz que o sujeito pode ser analisado com base na posição, no controle sobre o verbo e na marcação morfológica de caso nominal.

Cumpre salientar que, neste trabalho, adotamos como critérios de identificação do sujeito: a posição pré-verbal e o controle sobre a morfologia do verbo, características típicas do Português Brasileiro em seu padrão culto. 


\title{
1.2.2. Papéis Semânticos
}

Os papéis semânticos devem ser entendidos em termos textuais, pois atendem a anseios comunicativos da linguagem. De acordo com Payne,

\begin{abstract}
Papéis semânticos são papéis conceituais e relações no plano discursivo. Em qualquer cena, há vários atores com papéis específicos a desempenhar. Se a cena envolve, por exemplo, o processo de comer, haverá necessariamente dois atores no palco, cada um com um papel específico - há alguém ou alguma coisa que inicia e controla a ação (quem come) e algo que é afetado por essa ação (a coisa comida). (tradução nossa) ${ }^{7}$
\end{abstract}

(PAYNE 2011, p. 134)

Tanto Givón (2001) quanto Payne (2011) advertem que os papéis semânticos têm representantes prototípicos e não são categorias rígidas com fronteiras bem delimitadas. $\mathrm{O}$ enunciador escolhe (in)conscientemente como construir a cena e quem é um candidato mais forte para determinado papel, dependendo do efeito desejado sobre o interlocutor.

Os principais papéis semânticos são, segundo esses autores:

a) Agente: prototipicamente, um agente é um ser animado com volição que provoca/ou inicia uma mudança de estado em um paciente de maneira voluntária.

(2) O índio Mundurukú matou a anta para alimentar a si e a sua família.

No exemplo acima, o índio Mundurukú deliberadamente iniciou um processo de caça e matou a anta, que passa para o estado de morta.

b) Paciente: prototipicamente, aquele que sofre, por influências externas, uma mudança de estado; pode ser animado ou inanimado.

(3) O índio Mundurukú matou a anta para alimentar a si e a sua família.

Como dito no exemplo acima, aqui a anta não iniciou o processo, ela é alvo desse processo que provoca mudanças em seu estado; portanto, ela é a candidata mais prototípica para o papel de paciente.

\footnotetext{
7 Semantic roles are conceptual roles and relationship on the discourse stage. In any play, there are various actors with particular roles to play. If a scene involves, for example, an event of eating, there must be two participants on stage, each with a very particular role - there must be someone or something that initiates and controls the action (the "eater") and something that is affected by the action (the eaten thing). (PAYNE 2011, p. 134)
} 
c) Força: uma entidade inanimada, portanto, sem volição e sem consciência, que afeta um paciente.

(4) O vento derrubou a oca.

O vento é uma entidade da natureza, sem vontade própria que provoca uma mudança de estado físico da oca.

d) Estímulo: algo que origina ou estimula uma sensação ou sentimento de um ser animado. Importante lembrar que os estímulos não sofrem alteração de estado.

(5) De um modo geral, o povo brasileiro adora mandioca.

Nesse exemplo, a mandioca provoca uma sensação de satisfação no povo brasileiro, não havendo, no entanto, uma mudança de estado. Não há nem mesmo um processo, como nos exemplos anteriormente citados.

e) Destinatário: é um ser animado ao qual algo ou alguém se endereça. Prototipicamente, a ação não o afeta, não há mudança de estado necessariamente.

(6) Uma intimação foi enviada à liderança indígena.

Nesse caso, a liderança indígena receberá a intimação; portanto, ela é o destino final da intimação, mas apenas isso não provoca nenhuma mudança de estado.

f) Beneficiário/ Benefactivo: é um ser animado que não é afetado diretamente, mas tira proveito de algo, é beneficiado de uma ação.

(7) Os indígenas Mundurukú receberam alimentos durante o encontro.

Aqui, os indígenas Mundurukú não iniciaram nenhum processo, mas são beneficiados por alguém que os alimenta. 
g) Instrumento: participante tipicamente inanimado utilizado por um agente para executar uma ação.

(8) Os policiais dispersaram os manifestantes com balas de borracha.

As balas de borracha foram o meio utilizado pelos policiais para iniciar esse processo de dispersão dos manifestantes.

h) Locativo: lugar onde se desenrola um evento ou determinada entidade se situa.

(9) Lideranças indígenas Mundurukú se reúnem em Brasília para discutir sobre as usinas hidrelétricas.

Brasília é o cenário em que a reunião se desenvolve, podendo ser omitido ou deslocado, dependendo das forças discursivas em questão.

i) Alativo: lugar para o qual algo ou alguém se desloca ou é transferido (destino).

(10) Índios Mundurukú vão ao Congresso Nacional nesta tarde.

O Congresso Nacional é o destino físico dos Mundurukú nesse enunciado. É um importante papel semântico nesse caso, pois o ponto de chegada pode dizer muito sobre a intenção.

j) Ablativo: lugar de origem a partir do qual algo ou alguém se desloca ou de onde é transferido.

(11) Os índios Mundurukú chegaram do Pará hoje pela manhã.

Pará é o ponto inicial de uma jornada dos indígenas. A origem pode fornecer pistas importantes sobre as inferências que o enunciador espera que seu interlocutor faça. 
Esses são apenas alguns exemplos de possíveis papéis semânticos a serem analisados ao longo do trabalho. A partir dos exemplos dados acima e como veremos durante as análises, podemos perceber que a correspondência entre sujeito e agente nem sempre é verdadeira, assim como também é falsa a afirmação de que todo objeto é paciente. Para o funcionalismo, tais afirmações são, entretanto, um protótipo dessa relação. Espera-se, por exemplo, que o sujeito seja agente e tópico. Quando esse alinhamento prototípico entre relação gramatical, papel semântico e papel pragmático é alterado, que efeitos isso traz ao texto e à sua interpretação? Quem é posto em evidência e/ou quem é posto em segundo plano? Essas são algumas das questões que iremos analisar ao longo desta pesquisa nos discursos midiáticos sobre os índios brasileiros. Mas, antes, vejamos o que são papéis pragmáticos.

\subsubsection{Papéis Pragmáticos}

As línguas apresentam diferentes maneiras de apresentar as informações. A escolha terá como base o contexto discursivo, a intencionalidade do falante e o contexto. Via de regra, o enunciador desenvolve um comentário a partir de uma informação já compartilhada que se chama tópico. Já a informação nova é chamada de foco. Ele é um elemento do enunciado com valor informativo novo ou contrastivo. Payne (1997) afirma que o tópico é o ponto de partida para uma proposição; é, pois, aquela informação já conhecida pelos participantes e difere da topicalização, que traz para a posição de tópico uma informação que prototipicamente não estaria ali.

Tendo o foco esse valor novo, o enunciador pode optar por colocá-lo em destaque, caso considere que a informação nova é a mais importante. Por exemplo:

(12) Foram os índios que assinaram o acordo. (e não outro grupo)

Como afirma Givón (2001, p. 222), o processo de foco contrastivo que podemos observar no enunciado acima só faz sentido se considerarmos o contexto discursivo. A informação nova é inesperada e faz oposição às expectativas do interlocutor. Podemos pensar que, em determinado contexto, esperava-se a informação de que o governo havia assinado um acordo, mas a construção dada em (12) quebra essa expectativa e apresenta uma informação que até então não era prevista. Nesse exemplo, a estratégia da clivagem é a escolhida, porém existem outras maneiras de contrastar informações. 
De acordo com Castilho (2010), a focalização é um

Recurso prosódico ou gramatical para assinalar o foco. A focalização pode ser obtida mediante (1) pronúncia enfática do segmento que se quer destacar, por em relevo, como em VOC $\hat{\mathbf{E}}$ é que deveria falar; (2) o uso de operadores tais como a expressão clivadora é que, em Você é que deveria falar, ou uso de um advérbio de focalização, como em "Só/apenas/unicamente você̂ deveria falar.

(CASTILHO, 2010, p. 675) (grifos nossos)

Segundo Givón (2001), o foco de contraste pode ser uma opção quando há desconhecimento por parte do interlocutor ou quando ele tem fortes crenças contrárias às informações que o enunciador dará. De qualquer maneira, é um recurso que extrapola o nível sintático e prosódico, tendo motivações extralinguísticas e que muito nos diz sobre o sentido que provoca quando utilizado.

A topicalização, por sua vez,

é, fundamentalmente, uma dimensão cognitiva, que se relaciona com o foco de atenção em um ou dois participantes (...) importantes durante o processamento de orações em que há vários participantes. Como a atenção é uma capacidade mental limitada, situações complexas com vários participantes forçam uma distribuição seletiva deles. (tradução nossa) ${ }^{8}$

(GIVÓN, 2001, p. 217)

A partir daí, entendemos que o tópico pode depender do contexto e da intencionalidade, e ser escolhido pelo enunciador. Normalmente, humanos ou agentes ocupam a posição de tópico, seguindo a escala de topicalidade/agentividade abaixo representada:

Figura 1 - Escala de topicalidade/agentividade

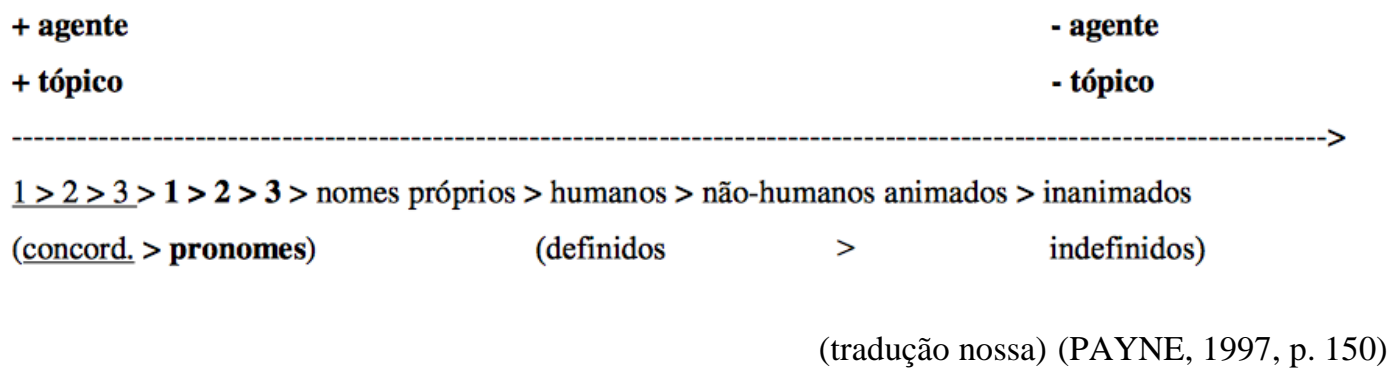

\footnotetext{
8 Topicality is fundamentally a cognitive dimension, having to do with the focus of attention on one or two important events-or-state participants during the processing of multi-participant clauses. Since attention is a limited mental capacity, complex multi- participant situations force its selective deployment. (GIVÓN, 2001, p. 217)
} 
Payne (1997) aponta as características mais prototípicas do tópico/agente quando comparado ao foco/paciente. Como no Português o agente normalmente ocupa essa posição de tópico, o que encontramos é uma entidade com traços mais humanos, podendo estar representada por pronomes definidos ou nomes próprios. O paciente, por sua vez, ocupa a função de foco e normalmente é caracterizado por entidades não humanas, inanimadas e indefinidas. Ao menos essa é uma caracterização prototípica das relações gramaticais com os papéis semânticos e pragmáticos, em que se alinham o sujeito/agente/tópico de um lado, e o objeto/paciente/foco de outro lado.

Mas os falantes das línguas, em geral, se utilizam de construções marcadas (por exemplo, a passiva ou a causativa) para expressar como tópico uma entidade não-humana ou paciente. A passiva é, segundo Shibatani (1985), uma estratégia para desfocalizar um argumento agente. Assim, podemos reconhecer a passiva, por exemplo, como um processo em que um tópico não prototípico (o paciente) ocupa a posição de sujeito. Esse processo pode ser entendido como um tipo de topicalização.

Nas notícias que analisamos no escopo desta dissertação, foi relevante verificar quais são os dados comumente compartilhados (tópicos) e quais as novas informações (focos). As estruturas topicalizadas, principalmente, também nos darão pistas sobre qual o sentindo que se quer construir, assim como os possíveis processos de focalização. Como esses processos regidos pragmaticamente ocorrem em meio a operações de voz e valência verbal, a seguir tratamos desses construtos.

\subsubsection{Voz verbal strictu sensu e lato sensu}

Voz verbal strictu sensu é determinada por uma alteração morfológica no verbo que afeta as RGs e outras partes do enunciado para fazer operar uma mudança no plano pragmático e, em alguma medida, no plano semântico.

A voz verbal pode ser percebida, segundo Camacho (1999), como uma perspectivação.

Há situações em que o ponto de vista imposto à predicação permite falar em termos de sentença marcada. São situações de desarticulação entre a sequência natural do estado de coisas e a ordenação dos argumentos e satélites da predicação. Variações de voz são mecanismos linguísticos típicos de seleção de uma perspectiva ao evento relatado e as únicas situações que, para Dik (1989), constituem projeções de perspectiva.

(CAMACHO, 1999, p. 159) 
Para Givón (1994, p. 375), voz verbal também é uma forma de delinear uma perspectiva pragmática; é uma maneira de identificar o ponto de vista do qual um determinado evento é assistido. Por exemplo:

(13) Governo assina acordo sobre a demarcação de terras.

Um evento semanticamente transitivo, como o representado pelo exemplo acima, pode ser visto tanto do ponto de vista do agente quanto do paciente. Isso vai ser determinado por fatores pragmáticos. O enunciador escolhe quem é tópico e quem é foco, e quem participará da cena discursiva e em que plano (primeiro ou segundo). Em (13), temos um evento pontual, real, com sujeito agente, animado e com volição, mesmo que, metonimicamente, esteja representado por uma entidade abstrata (governo), o que lhe confere mais força ainda. O paciente é afetado pela ação verbal e é inanimado ( $a c o r d o$ ). Uma mudança de voz para uma construção passiva, por exemplo, mostraria uma mudança na pragmática, na topicalidade e na intencionalidade. Mais do que isso, teríamos alterações nos papéis pragmáticos e nas funções sintáticas. Todas essas alterações motivadas por forças discursivas.

Pezatti (1994, p. 43) lembra ainda que

\begin{abstract}
DeLancey (1981) considera que uma parte significativa da estrutura semântica de uma língua constitui uma lista de cenas prototípicas, especificadas por um conjunto canônico de participantes. Uma sentença descreve um evento real ou imaginário, invocando a cena prototípica de que ela é um exemplo e identificando os papéis dos participantes com entidades existentes no universo do discurso. Na comunicação real, nem todos os aspectos do evento prototípico têm igual interesse. Assim, todas as línguas são dotadas de mecanismos para marcar a importância comunicacional relativa das várias entidades e eventos na sentença ou no discurso. Tal fato está relacionado a duas noções psicológicas, fluxo de atenção e ponto de vista, parâmetros fundamentais que contribuem para determinar o interesse relativo de várias entidades envolvidas no evento real.
\end{abstract}

Assim, uma alteração na voz verbal implica uma mudança de ponto de vista, ou melhor, uma mudança na perspectiva que se quer forjar implica uma alteração na voz verbal. Vejamos o exemplo abaixo:

(14) O acordo sobre demarcação de terras foi assinado pelo governo. 
No exemplo (14), o tópico passa a ser o acordo. O evento é mais estático, com sujeito paciente, inanimado e sem volição. Como já dito, a opção por um enunciado como o representado em (13) ou por outro, como em (14), dependerá do contexto e da intencionalidade do enunciador, do que ele quer colocar em primeiro ou em segundo plano.

Thompson (1994, p. 47) estabelece que

\begin{abstract}
As construções de voz, como passivas e antipassivas, podem ser vistas como estando relacionadas a outras construções em dois diferentes níveis. No primeiro nível, se relacionam com outras construções que suprimem argumentos e tornam o verbo menos ativo. Entre elas, temos as reflexivas, médias, anticausativas, impessoais e outras. Num segundo nível, passivas e antipassivas se relacionam com construções que marcam a relativa topicalidade de um agente e de um não-agente. (tradução nossa $)^{9}$
\end{abstract}

Assim, no exemplo (14), vemos que a forma verbal foi assinado, quando comparada à forma verbal assina, apresenta um aspecto mais estativo. O governo poderia ser omitido, sem prejudicar a gramaticalidade do enunciado. Nas notícias analisadas neste trabalho, discutiremos, por exemplo, quais as motivações que levam à construção desse enunciado e não de uma voz ativa. Levar o governo para uma posição de menor destaque pode significar uma tentativa de esconder quem assinou o acordo. No contexto histórico atual, marcado por constantes disputas por terras, quais os efeitos que uma notícia pretende causar na mente de seu leitor ao optar por essa estrutura?

Como veremos na seção seguinte, a opção por uma voz verbal e não outra pode representar uma oportunidade de diminuição ou de aumento de argumentos. Tudo isso com sérias implicações no que diz respeito às possíveis interpretações que serão feitas pelo leitor.

\title{
1.2.5 Valência sintática
}

Para Payne (1997), a valência pode ser pensada como uma noção semântica, sintática ou uma combinação delas. Segundo o autor, a valência sintática está relacionada ao número de argumentos presentes sintaticamente em uma oração.

\footnotetext{
${ }^{9}$ Voice constructions such as passives and antipassives can be seen as being related to other constructions in two different levels. On the one level is their relationship to other constructions that suppress arguments and make the verb less active. Among these are reflexive, "middles", anticausative, impersonals and the like. On the other level passives and antipassives are related to constructions marking the relative topicality of the agent and a non-agent. (THOMPSON, 1994, p. 47)
} 
Um argumento sintático de um verbo é um elemento nominal (incluindo possíveis zeros, desde que esse seja um dispositivo referencial na língua) que estabelece com o verbo uma relação gramatical. Então, por exemplo, um dado uso do verbo comer em inglês pode ter uma valência sintática um ou dois. Em uma sentença como Você ainda não comeu?, não há um objeto direto, e o único argumento do verbo é o comedor. (tradução nossa) $^{10}$

(PAYNE, 1997, p. 170)

\section{Exemplo:}

(15) Índios invadem prédio da Sesai no centro de Boa Vista.

(fonte: $\quad$ http://globotv.globo.com/rede-amazonica-rr/g1-rr/v/indigenas-invadem-predio-da-sesai-nocentro-de-boa-vista/3901968/)

Em (15), temos dois argumentos, dois termos que se relacionam sintaticamente com o verbo invadir: índios e prédio da Sesai. Índios está exercendo a função de sujeito, pois está em posição pré-verbal e controla a morfologia do verbo. Enquanto isso, prédio da Sesai está na função de objeto, já que completa estrutural e semanticamente o verbo; é também um paciente, pois sofre uma mudança de estado provocada pela ação expressa pelo verbo, papel semântico típico (mas não exclusivo) de objetos diretos. Temos, nesse exemplo, um verbo bivalente. Ele seleciona dois argumentos que estão presentes sintaticamente para conferir sentido completo à estrutura.

A valência sintática pode ser aumentada, diminuída ou rearranjada, dependendo de fatores semânticos e/ou pragmáticos. Sobre isso, falaremos mais detidamente na seção 1.2.7.

\subsubsection{Valência Semântica}

A valência semântica, para Payne (1997, p. 169), refere-se ao número de participantes que podem estar no palco, na cena expressa pelo verbo. Em uma passiva prototípica, por exemplo, a presença de um paciente é obrigatória, tendo em vista que ele ocupa a função sintática de sujeito; mas a presença do agente não é obrigatória, por estar ele em função de adjunto adverbial; todavia, semanticamente, a passiva prevê tanto paciente quanto agente, sendo a presença efetiva deste último uma opção para o falante. Logo, em uma passiva, temos a valência semântica dois, embora a valência sintática seja um.

Também é possível encontrarmos construções como Calvin já comeu?. Nessa estrutura,

\footnotetext{
10 A syntatic argumento $\mathrm{f}$ a verb is a nominal elemento (including possibly zero, if this is a referencial device in the language) that bears a gramatical relation to the verb. So, for example, a given instance of the verb eat in English may have a syntatic valence for one or two. In a sentence like Have you eaten yet? There is no direct object, so the only argument of the verb is the eater. (PAYNE, 1997, p. 170)
} 
não importa dizer o que foi comido ou não se sabe. De qualquer maneira, ainda está implícito que algo foi comido, mas não era uma informação importante para o evento comunicativo. Nesse exemplo, o verbo tem apenas um argumento (valência sintática), apesar de semanticamente estar prevista a presença de dois participantes (valência semântica). Houve, sim, mudança de sentido do verbo comer, que passou a significar alimentar-se. O mesmo não ocorre em “João comeu maçã, e eu não comi”. Nesse caso, há um pronome anafórico zero na função de objeto direto na segunda ocorrência de comer. Aí teremos dois argumentos nos dois usos de comer, e o sentido do verbo continua sendo o mesmo.

Outro exemplo desse tipo é o verbo beber, tipicamente bivalente, que pode ser utilizado em contextos específicos como monovalente, uma forma que está consagrada pelo uso e com um significado bastante particular:

(16) Índio bebe muito.

No exemplo (16), que representa um dos estereótipos atribuídos aos índios brasileiros, sabemos que, sintaticamente, o verbo está sendo usado como monovalente. Só temos uma relação gramatical: o sujeito índio. O que é bebido está implícito. Só somos capazes de inferir que se trata de bebida alcoólica e não um suco, por exemplo, porque esse uso para o verbo beber já está consagrado em nossa sociedade. Aí também ocorre uma diminuição da valência sintática.

Assim, percebemos que existe um jogo para alternar a valência (proto)típica dos verbos para adequar seu uso à situação comunicacional, e é disso que trataremos na seção a seguir.

\subsubsection{Operações que alteram valência}

Como vimos na seção anterior, a valência sintática e a valência semântica atendem a anseios estruturais, semânticos e pragmáticos da língua. Alternar a valência significa diminuir, aumentar ou rearranjar os argumentos selecionados pelo verbo. Por exemplo, comparando os enunciados a seguir, percebemos que há uma alteração no número de argumentos sintáticos exigidos pelo verbo:

(17) O índio pescou um peixe. (Valências sintática e semântica: 2)

(18) Um peixe foi pescado. (Valência sintática: 1; Valência semântica: 2, pois ainda se pode prever um agente) 
Notamos que, em (17), temos a presença de dois argumentos na estrutura (índio e peixe). Ambos são previstos e exigidos pelo verbo. Enquanto isso, em (18), temos apenas a presença de um argumento (peixe), embora, semanticamente, saibamos que houve alguém que o pescou.

Não podemos, no entanto, pensar que este é um jogo puramente estilístico; as alterações na valência podem provocar até mudanças nos papéis semânticos como nos explicam Dixon \& Aikhenvald (2000, p. 06).

A maior parte das línguas tem algumas derivações verbais que afetam os argumentos do predicado. Tipicamente, elas reduzem ou aumentam o número de argumentos; alternativamente, o número de argumentos pode ser mantido, mas os papéis semânticos serão alterados. ${ }^{11}$ (tradução nossa)

Ao escolher uma estrutura que me permite omitir quem pescou, trago peixe para a posição de tópico, reduzo a valência e digo ao meu interlocutor que não importa quem pescou ou não sei dizer quem foi. Sobre os efeitos que o uso da voz passiva provoca, falaremos mais detidamente na seção 1.2.1.1. Interessa-nos dizer que as operações que alteram valência não são escolhidas ao acaso e têm implicações discursivas.

Assim, procuramos, neste trabalho, identificar quando essas alterações na voz ocorrem e o porquê disso ocorrer. Pensando no nosso tema de pesquisa, quando as relações gramaticais, os papéis semânticos e/ou os pragmáticos são alterados, para que posição as comunidades indígenas são movidas preferencialmente?

\subsubsection{Operações que reduzem valência}

Segundo Payne (1997, p. 196), as línguas podem ter formas morfológicas, lexicais e perifrásticas/analíticas de reduzir a valência de um verbo. Reduzir a valência significa manipular um enunciado de maneira que se possa excluir ao menos um de seus argumentos. Usando a metáfora de Payne do palco, quando um ator é tirado de cena ou colocado ao fundo, o destaque recai sobre alguém que antes estava em um papel secundário. Esse tipo de operações atende a anseios discursivos; portanto, quando um argumento é tirado de cena, devemos nos

\footnotetext{
11 Most languages have some verbal derivations that affect predicate arguments. Typically, they may reduce or increase the number of core arguments; alternatively, the number of core arguments may be retained but their semantic roles altered. (DIXON E AIKHENVALD, 2000, p. 06)
} 
perguntar o que motiva essa saída e quais as implicações semânticas e pragmáticas desse jogo de cena.

Neste trabalho, em específico, investigamos as ocorrências da voz passiva nas notícias analisadas, excelente representante dessas operações. Embora haja ainda outras operações como as reflexivas, recíprocas e médias, não há tempo hábil para trabalharmos com todas elas. Nossa análise prévia do corpus nos indicou que as passivas têm maior número de ocorrência dentre as operações citadas.

\subsection{Passivas}

As gramáticas tradicionais tratam a passiva como uma mudança de voz em que "a pessoa ou coisa, a que se atribui a ação verbal, recebe a ação em vez de praticá-la" e alegam não haver mudança de sentido. (ALMEIDA, 1977, p. 185). Ora, essa é uma definição muito simplista. Examinemos, por exemplo, o enunciado a seguir:

(19) Um índio foi morto.

Em (19), há efetivamente uma ação sendo recebida pelo sujeito? Trata-se apenas de receber a ação? Se sim, quem a pratica? Se não, o que a voz passiva me diz sobre o sujeito? Aliás, quem é o sujeito? Por que não sabemos quem é o agente? Quais motivações pragmáticas levaram o enunciador a não explicitar o agente? Ele é obrigatório? Em que nível estamos analisando a voz passiva? Qual quadro mental se forma ao lermos esse enunciado? Tais questionamentos surgem sempre que analisamos uma construção passiva como a apresentada em (19). Nem mesmo estamos diante de uma ação. Já é um fato, um quadro estático. É o resultado de uma ação.

Partindo do conceito de Almeida sobre voz passiva, não somos capazes de responder a tais questões; na verdade, se formos considerar sua definição de passiva, nem mesmo chegaremos a tais questões. Muitas vezes, as gramáticas tradicionais chegam ao extremo de afirmar que a passiva corresponde exatamente ao que se afirma na voz ativa. É, portanto, necessário que façamos uma análise mais profunda sobre a função da voz passiva. Devemos também determinar qual o nível de análise que fazemos. 
Segundo Gomes (2005, p. 47), do ponto de vista da tipologia funcional, na passiva,

O agente perde grau de importância sintática e pragmática, o paciente torna-se sujeito gramatical, assumindo papéis reservados a essa função sintática, e passa a ser o constituinte pragmaticamente mais relevante, o verbo é intransitivizado, e a ordem preferencial de palavras (SVOBL) explicita uma hierarquia sintático-pragmática entre o novo sujeito (paciente) e o antigo sujeito (agente).

No nível morfossintático, a passiva apresenta mudança na morfologia verbal e alteração dos participantes semânticos que ocupam as RGs. Em um enunciado ativo prototípico, temos um sujeito diferente daquele expresso pela passiva.

As passivas são um ótimo exemplo de uma operação de diminuição de valência, pois diminuem o valor de determinado participante, chegando ao ponto de ele não ser mais um argumento e tornar-se, portanto, passível de apagamento.

No nível semântico, observamos na voz passiva um aspecto muito mais pontual, um quadro mental mais estático do que na voz ativa que, tipicamente, apresenta um aspecto mais processual.

Em termos pragmáticos, a voz passiva traz para a posição de tópico um sujeito que não é agente, que, como dito anteriormente, não é o protótipo de sujeito. Esse fenômeno pode ser observado nos exemplos (20) e (21) a seguir.

(20) O acordo não foi assinado (pelos indígenas).

(21) A reunião foi cancelada (pelo ministro).

Em (20) e (21), apesar de sabermos que houve um agente que não assinou o acordo e um que cancelou a reunião, torna-se possível omitir tais agentes. As motivações discursivas por trás dessa estratégia podem ser as mais diversas: i) não é interessante que meu leitor saiba quem são; ii) não é importante dizer; iii) não sei quem são os agentes; iv) importa destacar o paciente, etc. Podemos afirmar que houve uma diminuição no valor sintático de indígenas e ministro, porque há a presença de uma preposição e não é possível pronominalizar esse participante agente. Em ambos, podemos perceber que o sujeito não é humano, nem animado. Em busca de respostas mais discursivas sobre esses usos, analisamos as passivas presentes nas notícias (cf. capítulo 4). 


\subsubsection{Operações que aumentam valência}

Da mesma forma que a língua dispõe de operações e mecanismos que diminuem a valência, há também as operações que a aumentam. Payne (2011, p. 317) afirma que essas operações podem adicionar um participante controlador (como no caso das causativas) ou ainda promover um participante que antes era periférico (como no caso do dative-shift).

Payne (2006, p. 240) acrescenta, ainda, que os principais processos de aumento de valência são: i) causativas; ii) aplicativas; iii) dative-shfit; iv) subida do possuidor; e v) dative of interest.

Neste trabalho, interessam-nos as causativas, pois nosso primeiro levamentamento de dados nos mostrou que essas construções são mais recorrentes no discurso jornalístico brasileiro sobre o indígena.

\subsection{Causativas morfológicas, lexicais e perifrásticas}

De acordo com Shibatani (1976, p. 239), as causativas devem ser tratadas como voz verbal quando a construção expressa, semanticamente, uma situação de causa-efeito de forma dependente, ou seja, o efeito está submisso à causa; sem ela, ele não ocorreria. Causativas são as mudanças verbais que acarretam aumento da valência, trazendo para a cena discursiva um novo participante/argumento que até então não era previsto. Esse novo participante exerce forte controle sobre outro participante, e torna-se uma espécie de superagente, que exerce um controle sobre a ação de outro participante.

Payne (1997, p. 176) define a causativa como "uma expressão linguística que contém, em uma estrutura lógico-semântica, um predicado de causa (...) e um predicado expressando um efeito. Uma construção causativa pode ser expressa pela relação: Causa (x, P) = x causa P.” (tradução nossa) $)^{12}$.

Segundo Shibatani (2001, p. 137), tipologicamente, já foram identificados três tipos de causativas: morfológicas, lexicais e perifrásticas.

As causativas morfológicas são aquelas que envolvem uma mudança produtiva na forma do verbo (PAYNE, 2006, p. 259). De acordo com Gomes (2005, p. 49), em Mundurukú, língua indígena falada por uma comunidade do Pará, por exemplo, o sufixo $\{$-at $\}$, é produtivo no que tange às causativas:

\footnotetext{
${ }^{12} \mathrm{~A}$ causative is a linguistic expression that contains in semantical/ logical structure a predicate of cause (...) a predicate expressing effect. A causative construction can be symbolized as: Cause $(\mathrm{x}, \mathrm{P})=\mathrm{x}$ causes P. (PAYNE, 1997, p. 176)
} 


\section{(10) a) Pedro akurice o' = jo - wuy \\ Pedro cachorro $3 \mathrm{sa}=\mathrm{NCNT}-$ lavar.PRF \\ 'Pedro lavou o cachorro'}

\section{(10) b) Maria Pedro be akurice o'= jo - wuy - at Maria Pedro POSP cachorro 3sa $=$ NCNT-lavar.PRF-CAUS2 'Maria fez Pedro lavar o cachorro'}

(exemplos de Gomes, 2005, com numeração original preservada)

Vemos, no exemplo (10b), que foi introduzido um terceiro participante, Maria, que não era prevista em (10a). Essa nova participante assume o controle sobre Pedro que antes era o sujeito agente em (10a). Em (10b), Pedro passa a ser posposicionado, perdendo valor sintático, além de perder parte da volição e do controle sobre a ação.

Nem todas as línguas dispõem, no entanto, de recursos morfológicos para exprimir o fenômeno da causatividade. Assim, outros recursos, como o léxico e construções perifrásticas, podem ser utilizados.

As causativas lexicais são as que, segundo Payne (1997, p. 177), carregam a noção de causa atrelada ao próprio sentido lexical do verbo, como podemos notar nos exemplos (22) e (23), a seguir:

(22) A árvore caiu.

(23) O madeireiro derrubou a árvore.

Analisando o par de enunciados (22) e (23), notamos que, em (23), é adicionado um participante que tem uma leitura de agente. A árvore não caiu sozinha, alguém a fez cair. No exemplo (23), o madeireiro é um novo participante que não está previsto em (22). A noção da causa que fez a árvore cair é trazida pelo verbo derrubar. Percebe-se, também, que há uma noção de causa mais direta, até mesmo fisicamente. Tipologicamente, já se identificou que o quadro mental que se estabelece é de um contato mais direto entre o madeireiro e a árvore. A mesma noção se dá quando dizemos, por exemplo, que A mãe sentou a criança. O quadro é de uma mãe forçando fisicamente a criança a se sentar e não da mãe ordenando que a criança se sente sozinha. Essas imagens formadas mentalmente se relacionam diretamente com o conceito de iconicidade diagramática apresentado na seção 1.3.3 desta pesquisa. 
Já as causativas perifrásticas ou analíticas são aquelas que envolvem um verbo que traz a noção de causa separada em um predicado específico. Verbos como forçar, fazer, causar instaurariam esse tipo de predicado de causa. E o predicado de efeito viria como complemento deles, em forma de uma oração.

(24) O madeireiro fez a árvore cair.

A causa no exemplo (24) é expressa pelo verbo fazer. Seu complemento, uma oração, expressa a consequência do ocorrido. A relação de proximidade entre o causador e o causado, no entanto, é diferente da expressa pelo enunciado (23). Por possuir maior material linguístico (conferir seção 1.3.3), o exemplo (24) expressa uma relação menos direta entre o madeireiro e a queda da árvore. Podemos pensar que, talvez, o madeireiro tenha se utilizado de uma motosserra ou até de outra pessoa para derrubar a árvore. O fato é que, em (23), fica mais evidente um agente que se utiliza da força e de um contato mais direto para derrubar a árvore. Essas questões de maior ou menor integração conceitual são bastante pesquisadas no quadro da linguística tipológica, a qual tem encontrado sistematicamente maior ou menor relação entre causa e efeito a depender do tipo estrutural de estratégia causativa utilizada na língua.

Essas diferenças, embora possam parecer sutis, devem ser ressaltadas em nossas análises, pois criam quadros mentais bastante diferentes nos leitores. A seguir, abordamos os principais construtos da Linguística Cognitiva que associamos à Linguística FuncionalTipológico nesta pesquisa, para formar o quadro teórico da Linguística Funcional Centrada no Uso ou Cognitivo-funcional.

\subsection{Construtos da Linguística Cognitivista}

\subsubsection{Categorização e Protótipo}

A categorização é o processo linguístico-cognitivo pelo qual organizamos o mundo. Pensemos, por exemplo, na categoria das aves. Provavelmente, vamos imaginar um animal com asas, bico, que ponha ovos e que possa voar como uma andorinha ou uma pomba, correto? Esse seria um exemplo prototípico de ave. Porém, o pinguim também é uma ave, embora não possa voar. 
De acordo com Chiavegatto (2009, p. 82),

\begin{abstract}
Os estudos sobre categorização, desenvolvidos por Rosch $(1975$, 1977) em Psicologia, abriram a possibilidade de que as línguas não são formadas por categorias tradicionais (aristotélicas), mas por categorias prototípicas. Enquanto nas categorias tradicionais os membros que a ela pertencem têm todos os traços que a enquadram na categoria, nas categorias prototípicas há um membro básico ou central, que comporta todas as características da categoria, e membros mais periféricos, que perdem alguns dos traços da categoria, afastando-se em maior ou menor escala do membro central ou prototípico.
\end{abstract}

Assim, transferindo a explicação dada pela autora para o âmbito da estrutura, podemos pensar que há estruturas que são mais usadas para falar de sujeitos, eventos e objetos específicos. Segundo Furtado da Cunha et al (2013, p. 28), a categorização “(...) diz respeito à semelhança ou identidade que ocorre quando palavras e sintagmas e suas partes componentes são reconhecidas e associadas a representações armazenadas".

O processo de categorização está intimamente ligado à cultura de uma comunidade. Como apresentamos na seção 1.1 deste capítulo, tanto o Funcionalismo em geral quanto a Linguística Centrada no Uso em particular procuram as motivações extralinguísticas que também dão origem às estruturas linguísticas. Por exemplo, em Japonês, a fonética dos números $4(s h i)$ e $9(k u)$ causam problemas. Isso porque são homófonos de morte e de sofrimento respectivamente. Assim, no Japão, os edifícios não possuem $4^{\circ}$ andar. Nos hospitais, os quartos de número 4 e de 40 a 49 também não existem. Podemos ver, então, que esses números são categorizados como algo ruim, que traz azar. Isso chega ao ponto de interferir no sistema organizacional do país. Enquanto isso, na cultura brasileira, para algumas pessoas o número 13 é o número da má sorte, enquanto 4 e 9 nos são inofensivos.

Assim, trazendo essa perspectiva cultural para nossa pesquisa, os vários povos indígenas brasileiros podem estar em uma categoria, enquanto outros países podem colocar suas comunidades indígenas em uma categoria distinta. Pesquisas históricas e antropológicas podem nos mostrar, por exemplo, como se deu o processo de colonização e de (des)integração das comunidades indígenas no Brasil e em outros países.

O conhecimento de mundo e o conhecimento linguístico caminham sempre juntos sob o prisma funcionalista. Como vimos, a linguística cognitiva sugere que nossas experiências mudam nossa percepção de mundo e, consequentemente, as estruturas linguísticas são remoldadas para refletir essa nova visão. Logo, a categorização influencia em escolhas lexicais. Enquanto alguns verbos como invadir e ocupar são amplamente selecionados para matérias 
jornalísticas sobre indígenas, outros verbos como acampar, exigir e viver são usados para outros grupos sociais. Alguns verbos são, portanto, mais prototípicos do que outros. Mas como definimos protótipo nesta pesquisa? O protótipo é o melhor representante de uma categoria, ou seja, aquele participante que carrega o maior número de informações comuns aos elementos da categoria e definidoras dela.

Segundo Rosch (apud FURTADO DA CUNHA ET AL, 2013, p. 29), "cada protótipo nos possibilita realizar um conjunto de tarefas inferenciais ou imaginativas sobre uma dada categoria". Assim sendo, no presente trabalho nos perguntamos: Quais seriam as estruturas prototípicas que o jornalismo usa para criar os estereótipos sobre os povos indígenas brasileiros? Que tipo de estratégias cognitivas são aí empregadas? Metáforas e metonímias são exemplos disso.

\title{
1.3.2 Metáforas e metonímias
}

Quando pensamos em metáforas e metonímias, rapidamente, nosso pensamento nos remete às aulas de literatura, à linguagem poética, pois elas são vistas apenas como um recurso estilístico. Mas, na verdade, esses são processos que permeiam e definem o nosso cotidiano de maneira que nem percebemos os complexos processos cognitivos aí envolvidos.

A metonímia, segundo Lakoff \& Turner (1989), é um mapeamento inserido em um mesmo domínio conceitual. É possível fazer referência a uma entidade desse domínio, fazendo uso de outra entidade desse mesmo domínio. De acordo com Lakoff \& Johnson (2003, p. 36),

\begin{abstract}
A metonímia (...) tem primordialmente uma função referencial, a qual nos permite usar uma entidade no lugar de outra. Mas a metonímia não se limita a um recurso referencial. Ela também tem a função de fornecer compreensão. Por exemplo, em metonímias classificadas como a parte pelo todo, há muitas partes que podem substituir o todo. A parte que escolhemos determina qual aspecto do todo estamos enfatizando. (tradução nossa) ${ }^{13}$
\end{abstract}

Vejamos o exemplo a seguir:

(25) O prédio foi invadido por indígenas.

\footnotetext{
${ }^{13}$ Metonymy (...) has primarily a referential function, that allows us to use one entity to stand for another. But metonymy is not merely a referential device. It also serves the function of providing understanding. For example, in the case of the metonymy part for the whole there are many parts that can stand for the whole. Which part we pick out determinies which aspect of the whole we are focusing on. (LAKOFF E JOHNSON, 2003, p. 36)
} 
No exemplo (25), o todo é usado em lugar da parte. Não sabemos se a invasão se deu em apenas uma sala, no hall de entrada ou no prédio todo (bastante improvável). Essa é uma estrutura bastante comum em manchetes. Devemos nos questionar quais as implicações pragmáticas desse enunciado. Quais inferências se espera que os leitores façam? O que implica dizer que o prédio todo foi invadido e não apenas uma parte dele?

A metáfora também visa construir compreensões, interpretações, categorizações da realidade. Mas, por sua vez, é uma transferência de conceitos entre domínios. Lakoff \& Johnson (2003, p. 7) trazem, na clássica obra Metaphors we live by, exemplos muito claros de como o processo metafórico está presente em nosso cotidiano, organizando nossa vida social, cultural, mental e comportamental. Primeiramente, os autores citam a metáfora "Tempo é dinheiro". A partir desse exemplo, desenvolvem uma série de construções que refletem esse pensamento como "Esse aparelho vai nos poupar horas.", "Como você gasta seu tempo?", "Você deve investir mais tempo em esportes", etc.

Podemos pensar que, em nossa sociedade, o tempo se tornou escasso e, por isso, o categorizamos junto com outras coisas que consideramos preciosas e que devem ser valorizadas. Por isso, prototipicamente, usamos verbos como gastar, investir, poupar, roubar, perder, ganhar, etc.

Segundo Furtado da Cunha et al (2013, p. 33), a metáfora na LFCU tem o papel de “(...) licenciar, mediante o processo de inferenciação, o uso de um dado conceito de base mais concreta, vinculado a alguma experiência sensório-motora, num contexto de significação mais abstrata (...)". Vejamos o exemplo a seguir:

(26) Os guardiões da floresta lutaram contra os garimpeiros.

O exemplo (26), uma manchete de jornal (cf. capítulo 4), requer que o leitor acione mentalmente quais as características atribuídas à entidade guardiões da floresta e as transfira para a entidade referenciada no texto, no caso, indígenas.

A partir desses conceitos de metáfora e metonímia, nos questionamos quais os domínios conceptuais são acionados quando os jornais estão tratando da temática indígena e quais inferências são produzidas ou são necessárias para entendermos os sentidos propostos por esses jornais.

A seguir, tratamos do conceito iconicidade, outro construto fundamental para entendermos a relação entre escolhas linguísticas e construção conceptual. 


\subsubsection{Iconicidade e iconicidade diagramática}

Uma visão funcional da gramática implica perceber que, como qualquer sistema biológico, as construções são adaptativas, não-arbitrárias e moldadas por fatores externos (GIVÓN, 2001, p. 34). Assim, podemos entender que há iconicidade motivando escolhas estruturais em determinados enunciados. Trataremos aqui apenas da iconicidade diagramática.

Entendemos como iconicidade diagramática a correlação entre forma e função. Necessariamente, essa correlação deve ser motivada, ou seja, em alguma medida, a construção de uma estrutura deve representar a estrutura do conceito expresso por ela. Martelotta (2010, p. 167) afirma que "a estrutura da língua reflete de algum modo a estrutura da experiência”. É o que podemos perceber nos exemplos (27) e (28), a seguir.

(27) Funcionários não trabalharam.

(28) A ocupação fez com que funcionários não trabalhassem.

A partir dos exemplos (27) e (28), notamos que (28) carrega mais material linguístico do que o primeiro. Do ponto de vista cognitivo, (28) também é mais complexo que (27): ele adiciona um participante a mais no cenário discursivo (um agente); além disso, a ideia carregada por ele é mais complexa (uma causativa expressando causa e efeito). Em (27), temos um sujeito (funcionários) e uma ação conduzida por ele, sob seu controle, aparentemente ao menos. Já em (28), a ocupação é o agente que retira a vontade dos funcionários.

Acerca disso, Givón (2001) identifica três tipos de iconicidade diagramática: a) de complexidade; b) de quantidade; c) de coesão:

a) iconicidade de complexidade: ideias mais complexas tendem a ser estruturadas com formas mais complexas. De acordo com Slobin (apud FURTADO DA CUNHA et al, 2013, p. 23) “aquilo que é mais simples e esperado se expressa através de mecanismos morfossintáticos menos complexos". As formas mais marcadas tendem, também, a ser menos frequentes no discurso. Elas demandam mais material, como veremos a seguir, além de maior esforço cognitivo do que as construções não-marcadas;

b) iconicidade de quantidade: quanto mais material linguístico utilizado, mais complexa é a informação. Martelotta (2010, p.24) resume bem esse conceito ao afirmar que: "quanto maior a quantidade de informação, maior a quantidade de forma, de tal modo que a estrutura de uma construção gramatical indica a estrutura do conceito que ela expressa”. Furtado da 
Cunha et al (2013, p. 23) completam: "quanto mais imprevisível (nova) for a informação para o interlocutor, maior será a quantidade de forma a ser utilizada e vice-versa"; e

c) iconicidade de coesão: a integração no plano cognitivo entre os elementos de uma sentença representa também uma maior integração morfossintática. O que está mais próximo mentalmente é colocado mais próximo no plano sintático. A distância linear corresponde a uma distância conceptual.

Nos exemplos (27) e (28) dados, observamos que a iconicidade pode ser tanto de quantidade quanto de complexidade. O exemplo (27), menos complexo no campo das ideias, é também expresso mediante o uso de menos material linguístico. Enquanto isso, o exemplo (28) demanda mais material linguístico para expressar uma ideia mais complexa e, ao mesmo tempo, com maior quantidade: um agente é acrescentado na cena discursiva. O exemplo (28) foi retirado de uma notícia envolvendo indígenas e será adequadamente analisado no capítulo 4, em que fazemos as análises dos textos jornalísticos.

A seguir, tratamos de outros construtos da linguística cognitiva que nos serão úteis na análise dos dados e que compõem o fazer linguístico cognitivo-funcional.

\subsubsection{Frames, estereótipos e modelos cognitivos}

Segundo Duque e Costa (2012, p. 67), nossa compreensão de mundo se baseia em generalizações e padrões de experiências já vivenciadas. Opondo-se ao que acreditava o behaviorismo clássico, as repostas aos estímulos não são apenas externas, mas também estão compostas por representações imagéticas em nossas mentes. Assim, quando produzimos um discurso ou o consumimos, precisamos acessar conhecimentos prévios que estão organizados em nossas mentes, os quais nos permitem decodificar as mensagens, suas intenções e objetivos. Ou seja, precisamos acessar nossos frames (FILLMORE, 1985, p. 235).

Para Croft \& Cruse (2004, p. 8),

Um falante produz palavras e construções em um texto como ferramentas para uma atividade em particular, mais especificamente para evocar um entendimento, uma compreensão particular; a tarefa do ouvinte é decifrar para qual fim aquelas ferramentas foram utilizadas, mais especificamente para evocar que entendimento, que compreensão. Ou seja, essas palavras e construções evocam um dado entendimento ou, mais especificamente, um frame; o ouvinte invoca um dado frame ao ouvir um enunciado para poder entendê-lo. (tradução nossa) $)^{14}$

\footnotetext{
${ }^{14}$ A speaker produces words and constructions in a text as tools for a particular activity, namely to evoque a particular understanding; the hearer's task is to figure out the activity those tools were intended for, namely to invoque that understanding. That is, words and constructions evoke an understanding, or more specifically a frame; a hearer invokes a frame upon hearing an unterrance in order to understand it. (CROFT \& CRUSE, 2004, p. 8)
} 
Assim, algumas ideias mais complexas de um texto evocam conhecimentos de mundo que não estão refletidos explicitamente na estrutura textual. Por exemplo, ao lermos sobre uma viúva, está na estrutura da palavra o morfema $\{-\mathrm{a}\}$, que nos permite dizer que se trata de uma mulher; porém, devemos igualmente evocar um conhecimento de mundo que nos diz que, além de mulher, essa pessoa já foi casada e o cônjuge faleceu. Isso só faz sentido se nossa cultura nos permitir acessar o frame casamento.

É igualmente importante que possamos entender os frames como elementos que vão nos ajudar a compreender as escolhas pronominais e lexicais dêiticas de um texto. Em nossa pesquisa, por exemplo, nossas análises nos indicaram que é comum que o pronome escolhido para se referir aos grupos indígenas seja o pronome "eles". Essa escolha nos mostra que, em nossa sociedade, o frame acionado para as comunidades indígenas não é o mesmo em que encaixamos o grupo social a que todos nós pertencemos.

Aqui, acionamos o conceito central ligado ao construto semântico frame: estereótipo. Nos dizeres de Crystal (2008, p. 198): "Em teoria semântica, frames são estruturas que codificam conhecimento sobre tipos estereotipados de objetos ou situações, com provisão especial para os papéis desempenhados pelas suas partes ou participantes" (tradução nossa). ${ }^{15}$ Que frames fazem parte de um conjunto de conhecimentos construídos historicamente sobre as comunidades indígenas? Como os jornais os acionam e os sustentam no imaginário dos seus leitores? Isso é o que vamos analisar no capítulo 4.

Tais frames ou tipos de conhecimentos estereotipados se organizam em domínios, como explica Chiavegatto (2009, p. 86).

A base de conhecimentos sobre a qual se organizam as construções linguísticas é adquirida a partir de experiências vivenciadas pelos indivíduos em suas comunidades, desde os primeiros anos de vida. Tais conhecimentos vão sendo armazenados na memória, parcialmente estruturados, hierarquizados e relativamente permanentes. São os domínios cognitivos.

Segundo a autora, porém, dizer que esses domínios ou modelos cognitivos são estruturados não significa dizer que sejam imutáveis. Essas experiências podem sofrer mudanças e se reestruturar. Elas serão acionadas para compor significados linguísticos em forma de modelos mentais cognitivos, imagens e modelos culturais.

Sobre os modelos cognitivos, Andreassen (2002, p. 01) afirma que

\footnotetext{
${ }^{15}$ In semantic theory, frames are structures that encode knowledge about stereotyped kinds of objects or situations, with special provision for the roles played by their parts or participants. (CRYSTAL, 2008, p. 198)
} 
A ideia geral de modelos cognitivos é que eles organizam nossas experiências em unidades estruturadas e complexas - uma espécie de gestalts conceituais (inconscientes): uma ideia que surge de Metaphors We Live By, em que se diz que "[...] estruturas multidimensionais caracterizam gestalts experienciais, as quais são meios de organizar experiências em um todo estruturado." (Lakoff \&Johnson 1980 p.81, Lakoff 1987, p. 68) (...) Os modelos cognitivos definem o que nós vamos tomar para ser (acima de tudo) um caso representativo dos casos comparáveis e "fornecem uma maneira convencionalizada de compreender uma experiência de forma simplificada. Isso pode dar conta de uma experiência real bem ou não" (Lakoff 1987, p. 126). (tradução nossa) ${ }^{16}$

Quando somos colocados diante de uma experiência, nos recordamos de um fato ou uma situação parecida e imediatamente recorremos a um possível padrão. Isso acontece também quando lemos um texto. Normalmente, as informações iniciais vão traçar o caminho mental que a interpretação deve seguir. Assim, se acessarmos nosso acervo mental sobre notícias envolvendo a temática indígena, conseguiremos reconhecer um padrão.

Segundo Givón (2013 p. 73), “todo fenômeno pressuposicional nas línguas naturais é pragmático, ou seja, definido em termos de hipóteses que o falante assume sobre o que o ouvinte provavelmente aceita sem problemas". A aceitação vem com a naturalização, com a rotina de informações construídas sobre a realidade, sejam elas reais ou não.

\subsection{Resumo do capítulo}

Neste capítulo, procuramos apresentar o quadro teórico principal nos qual nos apoiamos, especialmente os estudos funcionalistas e cognitivistas, que se somam na corrente Linguística Funcional Centrada no Uso ou Cognitivo-Funcional. Os conceitos de RGs, papéis semânticos e pragmáticos, voz, valência também foram aqui abordados. Estratégias de alteração da valência também foram apresentadas, especialmente aquelas a que esperamos recorrer nas análises que virão no capítulo 4. Trouxemos também uma discussão básica sobre os construtos do cognitivismo que usaremos: categorização, protótipo, metáfora, metonímia, iconicidade e frames.

\footnotetext{
16 The overall idea of cognitive models is then, that they structure our experiences into complex structured wholes - a sort of (unconscious) conceptual gestalts: an idea stemming from Metaphors We Live By, where it is said that "[...] multidimensional structures characterize experiential gestalts, which are ways of organizing experiences into structured wholes.” (Lakoff \& Johnson 1980 p. 81, Lakoff 1987 p. 68)(...) Cognitive models define what we take to be the (overall) representative case of comparable cases, and "provides a conventionalized way of comprehending experience in an oversimplified manner. It may fit real experience well or it may not." (Lakoff 1987 p. 126). (ANDREASSEN, 2002, p. 01)
} 


\section{Capítulo 2 - Discurso, Ideologia e Comunicação de Massa}

\subsection{Introdução}

Neste capítulo, apresentaremos e desenvolveremos os conceitos que utilizaremos dos Estudos Críticos do Discurso e do Jornalismo. Na seção 2.1, começaremos apresentando o que trataremos por discurso, ideologia, estereótipo e identidade/representação. $\mathrm{Na}$ seção 2.2, trataremos da relação discurso/texto, momento em que abordaremos as microestruturas de van Dijk (2003), as quais serão também consideradas nas análises do capítulo 4. Por fim, na seção 2.3, também serão apresentados os conceitos que utilizaremos da área da Comunicação. Mais especificamente, trataremos da teoria do agenda-setting, da notícia e sua estrutura básica, passando por sua produção. A partir desses conceitos, poderemos entender melhor o que chamamos na introdução deste trabalho de critérios de noticiabilidade. Com este capítulo, teremos abordado os demais princípios teóricos que regeram nossa pesquisa, além dos já apresentados no capítulo 1 .

\subsection{Discurso, ideologia, estereótipo e identidade/representação}

\subsubsection{Discurso}

O termo discurso é de difícil definição, mas essencial aos nossos propósitos nesta pesquisa. Sabe-se que há diferentes concepções de discurso e que algumas linhas de pesquisa consideram que há discurso em qualquer evento comunicativo, seja ele verbal, seja ele nãoverbal. Nosso foco de trabalho recairá somente sobre o discurso verbal.

Neste trabalho, trabalharemos principalmente com a concepção de van Djik sobre discurso. $\mathrm{O}$ autor afirma que o discurso é um evento comunicativo específico, complexo, que envolve atores sociais (normalmente esses atores são os pares escritor e leitor ou falante e ouvinte), localizados geográfica e historicamente. Mas também concordamos com Ramalho \& Resende (2011, p. 17) quando afirmam que o discurso “(...) significa o momento irredutível da prática social associado à linguagem; (...) significa um modo particular de representar nossa experiência de mundo".

Ainda para van Dijk, o discurso é um fenômeno social multidimensional: 
É ao mesmo tempo um objeto (sequência de palavras ou sentenças dotadas de sentido) linguístico (verbal e gramatical), uma ação (como uma asserção ou uma ameaça), uma forma de interação social (como uma conversa), uma prática social (por exemplo, uma aula), uma representação mental (um significado, um modelo mental, um conhecimento, uma opinião), uma interação, um evento comunicacional ou atividade (como um debate parlamentar), um produto cultural (como uma telenovela) ou até mesmo um produto econômico que é vendido e comprado (como um livro de romance). Em outras palavras, uma definição mais ou menos completa da noção de discurso envolveria muitas dimensões. (...) (tradução nossa $)^{17}$

(VAN DIJK, 2009, p. 67)

Nesta pesquisa, estamos falando de um produto da situação ou evento comunicativo. Assim, nosso objeto de estudo é a língua em uso. Mais precisamente, as escolhas linguísticas feitas pela imprensa ao comunicar acontecimentos relativos às comunidades indígenas brasileiras. É de suma importância que se estude o discurso da mídia impressa, pois, como evidencia van Dijk (2012a, p.73),

\begin{abstract}
Não há dúvida de que, dentre todas as formas de texto impresso, as dos meios de comunicação de massa são as mais penetrantes, se não as mais influentes, a se julgar pelo critério de poder baseado no número de receptores. Além dos discursos falado e visual da televisão, os textos de jornal desempenham um papel vital na comunicação pública. Ao contrário da crença popular e do senso comum entre os estudiosos, as notícias na imprensa são geralmente mais bem lembradas do que as notícias na televisão (Robinson e Levy, 1986) e são percebidas como qualitativamente superiores (Bruhn Jesen, 1986), o que pode ampliar sua influência persuasiva e, portanto, seu poder.
\end{abstract}

As escolhas linguísticas feitas pelos meios de comunicação impressos, portanto, podem revelar quais mecanismos linguísticos são utilizados para a manutenção de uma hegemonia ideológica. Veremos, a seguir, o que chamamos de ideologia no presente trabalho. Mas, antes, cabe um esclarecimento importante: neste capítulo, vamos falar em vozes do discurso, o que significa estar falando de um posicionamento enunciativo. Estaremos nos referindo à capacidade de expressar, por meio do discurso, o papel do indivíduo enquanto participante de um dado evento.

\footnotetext{
${ }^{17}$ It is at the same turne a linguistic (verbal, grammatical) object (meaningful sequence or words or sentences), an action (such as an assertion or a threat), a form of social interaction (like a conversation), a social practice (such as a lecture), a mental representation (a meaning, a mental model, an opinion, a knowledge), an interactional or communicative event or activity (like a parliamentary debate), a cultural product (like a telenovela) or even an economic commodity that is being sold and bought (like a novel). In other words, a more or less complete "definition" of the notion of discourse would envolve many dimensions (...) (VAN DIJK, 2009, p. 67)
} 


\subsubsection{Ideologia/Modelo de dominação de Thompson}

A noção de ideologia vem sendo amplamente utilizada em diversos trabalhos da área de ciências sociais. Nesta pesquisa, é de suma importância evidenciar esse conceito para que possamos entender como ele opera na construção de identidades e representações de grupos minoritários no Brasil.

Lembrando o conceito de ideologia de Marx e Engels, Martino (2013, p. 67) postula que a ideologia surge na revolução francesa para nomear os estudos das ideias, com o objetivo de encontrar fundamentos ou origens do pensamento humano. O ser humano é o fator motivador de formação das ideias e, consequentemente, de diversas ideologias. As relações sociais nos ajudam a construir nossas ideias; não podemos nos desvincular dessas relações, mas podemos transformá-las o tempo todo. Martino (2013, p. 70) define ideologia como

um modo específico de ver o mundo. De acordo com essa noção, a compreensão que os indivíduos têm da realidade não é neutra, pura ou natural. (...) Em outras palavras, uma ideologia é um conjunto de ideias e práticas a partir das quais uma pessoa interpreta o mundo ao seu redor.

Segundo van Dijk (2003), as ideologias tipicamente organizam as pessoas e a sociedade de maneira polarizada. Assim, o embate "nós" X "eles" é algo que se torna natural. Podemos ainda dizer que a premissa básica de qualquer ideologia é "dizer coisas positivas sobre nós e coisas negativas sobre eles". Um sentido que pode ainda ser estendido para "não dizer coisas negativas sobre nós mesmos e não dizer coisas positivas sobre eles" (VAN DIJK 2003, p.43).

É necessário, no entanto, que essa oposição seja apresentada como natural, verdadeira e inevitável, pois as ações do grupo decorrem desse sentimento de pertencimento e de estar agindo orientado para um suposto bem-estar social.

Thompson (1994) propõe cinco diferentes modos gerais de operação da ideologia e suas respectivas estratégias: 
Quadro 2. Modelo de dominação de Thompson

\begin{tabular}{|c|c|}
\hline Modos gerais & $\begin{array}{l}\text { Algumas estratégias típicas de construção } \\
\text { simbólica }\end{array}$ \\
\hline $\begin{array}{l}\text { Legitimação } \\
\text { (Relações de dominação podem ser mantidas se } \\
\text { apresentadas como legítimas.) }\end{array}$ & $\begin{array}{l}\text { Racionalização } \\
\text { (O falante constrói um raciocínio para mostrar que } \\
\text { relações ou instituições sociais devem ser aceitas.) } \\
\text { Universalização } \\
\text { (Interesses de uns são apresentados como } \\
\text { interesses de todos.) } \\
\text { Narrativização } \\
\text { (Na narração de histórias, o presente é apresentado } \\
\text { como integrante de uma tradição "eterna e } \\
\text { aceitável".) (p. 83) }\end{array}$ \\
\hline $\begin{array}{l}\text { Dissimulação } \\
\text { (Relações de dominação podem ser estabelecidas e } \\
\text { mantidas pelo fato de serem "ocultadas, negadas } \\
\text { ou obscurecidas" ou por serem apresentadas de } \\
\text { modo imperceptível.) (p. 83) }\end{array}$ & $\begin{array}{l}\text { Deslocamento } \\
\text { (Termos geralmente usados para menção a pessoas } \\
\text { ou objetos são usados para se referir a outros, dessa } \\
\text { forma, os sentidos bons ou ruins são transferidos } \\
\text { para o novo referente.) } \\
\text { Eufemização } \\
\text { (A descrição acrescenta uma valoração positiva.) } \\
\text { Tropo } \\
\text { (É o uso de figuras da linguagem. As formas mais } \\
\text { comuns de tropo são sinédoque, metáfora, } \\
\text { metonímia.) }\end{array}$ \\
\hline $\begin{array}{l}\text { Unificação } \\
\text { (Relações de dominação podem ser estabelecidas e } \\
\text { sustentadas por meio da construção de unidade } \\
\text { entre indivíduos, independentemente das } \\
\text { diferenças que os separam.) }\end{array}$ & $\begin{array}{l}\text { Estandardização } \\
\text { ("Formas simbólicas são adaptadas a um } \\
\text { referencial padrão", por exemplo, } \\
\text { desenvolvimento de uma linguagem nacional sem } \\
\text { levar em conta as diferenças sociais e linguísticas.) } \\
\text { (p. 86) } \\
\text { Simbolização da unidade } \\
\text { ("Construção de símbolos de unidade, de } \\
\text { identidade e de identificação coletivas".) (p. 86) }\end{array}$ \\
\hline $\begin{array}{l}\text { Fragmentação } \\
\text { (Relações de dominação são estabelecidas e } \\
\text { mantidas por meio da segmentação de indivíduos e } \\
\text { grupos que possam ser uma ameaça aos } \\
\text { dominantes.) }\end{array}$ & $\begin{array}{l}\text { Diferenciação } \\
\text { (Ênfase nas distinções entre pessoas e grupos.) } \\
\text { Expurgo do outro } \\
\text { (Construção de um inimigo para a sociedade.) }\end{array}$ \\
\hline $\begin{array}{l}\text { Reificação } \\
\text { (Relações de dominação são criadas e sustentadas } \\
\text { quando uma situação transitória é apresentada } \\
\text { como se fosse "permanente, natural, atemporal".) } \\
\text { (p. 87) }\end{array}$ & $\begin{array}{l}\text { Naturalização } \\
\text { (Apagamento da história dos fenômenos, que são } \\
\text { apresentados como naturais.) } \\
\text { Eternalização } \\
\text { (Fenômenos são apresentados como "permanentes, } \\
\text { imutáveis e recorrentes".) (p.88) } \\
\text { Nominalização } \\
\text { (Ações e participantes são transformados em } \\
\text { nome.) } \\
\text { Passivização } \\
\text { (Verbos colocados na voz passiva. Essa estratégia } \\
\text { e a anterior apagam os sujeitos e a ação como se os } \\
\text { acontecimentos acontecessem por si só.) }\end{array}$ \\
\hline
\end{tabular}

(Fonte: SILVA, 2009, p. 168)

Assim, todos os estudiosos apresentados nesta seção entendem que a ideologia se mantém tanto por meio da unificação construída mediante um discurso que dá ao leitor uma 
sensação de pertencimento quanto por meio da fragmentação, quando coloca o outro (no caso desta pesquisa, o indígena) em uma posição de estranhamento.

As estratégias utilizadas para tais fins nem sempre são evidentes, mas são legitimadas pela sociedade que enxerga no outro uma potencial ameaça ao bem-estar social e que acaba por estabelecer um estereótipo sobre os grupos minoritários.

\title{
2.1.3 Estereótipos
}

Sabemos que, assim como a noção de ideologia, o termo estereótipo é bastante utilizado no nosso discurso do dia a dia, tornando-se necessária uma definição desse conceito para o presente trabalho. Não é nossa intenção esgotar a discussão sobre o tema ou chegar a uma definição absoluta do que seria um estereótipo. E lembramos que parte dessa definição começou a ser construída no capítulo 1, na seção em que apresentamos o termo frame, com o qual estereótipo guarda uma relação direta.

É necessário, todavia, que se discuta esse conceito, pois, segundo Martino (2013, p. 24)

\begin{abstract}
Os meios de comunicação são responsáveis pela articulação de diferentes partes da sociedade. No entanto, essa articulação não é apenas desigual, como também pode causar efeitos indesejados e imprevistos no ambiente social. Conhecer os efeitos da mídia na sociedade é uma maneira de proteger a democracia de qualquer efeito colateral. (...) A seleção de notícias feita pelos jornais é responsável por definir o que as pessoas saberão a respeito da realidade.
\end{abstract}

A mídia pode, portanto, ser responsável pela criação de um estereótipo ou por sua manutenção, já que seleciona o que a sociedade saberá sobre as comunidades indígenas, que é o nosso tema.

Martino (2013, p. 25) afirma ainda que uma das finalidades dos estereótipos é constituir uma imagem mental que o ouvinte/leitor desenvolve ao relacionar o fato relatado aos acontecimentos prévios que compartilham alguns traços em comum. A definição do autor vai ao encontro do que prega a Linguística Centrada no Uso, pois não podemos pensar em experiências isoladas: nosso sistema cognitivo, até mesmo para categorizar nossas experiências, precisa relacioná-las a eventos prévios. Foi o que abordamos na seção sobre categorização, protótipo, metáfora, metonímia e frames no capítulo 1.

Embora não possamos confundir o conceito de estereótipo com o de protótipo, notamos que estão intimamente ligados, pois ambos exigem que haja, antes, um processo de categorização. Sobre categorização na perspectiva da Linguística Centrada no Uso, Furtado da Cunha et al (2013, p. 29) ressaltam ainda que 
Ao invés de serem definidas, em termos binários e discretos, as coisas percebidas distribuem-se num continuum categorial, em que alguns elementos localizam-se mais nos polos da escala, com propriedades conceituais mais ou menos definidas, e outros se situam em instâncias intermediaria, por compartilharem características de uma e outra categoria (...) A categorização permeia nossa relação com o mundo físico e social e com nosso intelecto.

Assim, a categorização nos permite fazer essa relação entre o fato novo e as experiências passadas. Caso um estereótipo se construa em nossa mente, ele se incorpora à nossa língua, muitas vezes em tons pejorativos, sem que tenhamos consciência desse processo. Um exemplo muito claro disso é a expressão "programa de índio". A linguagem, portanto, não é a realidade por si só. Mais do que isso, a linguagem mostra como nós sentimos, percebemos e traduzimos o mundo que nos cerca.

Ainda segundo Martino, essa relação da experiência com acontecimentos prévios permite que situações semelhantes sejam identificadas e que, sobre elas, se aplique a representação construída (cf. frames e domínios cognitivos no capítulo 1). Há, portanto, um reconhecimento superficial, que peca em profundidade. Essa relação, para muitas pessoas, adquire o status de verdade, sem uma reflexão mais profunda acerca do que se ouve ou lê. Nesse sentido, entendemos o porquê de sermos induzidos a preencher lacunas que são deixadas, de propósito, nos textos com sentidos que trazemos de leituras prévias.

No campo do jornalismo, por exemplo, quando uma notícia deixa uma lacuna, automaticamente pensamos em outras notícias que tenhamos lido com a mesma temática ou em outras notícias, elaboradas por outros jornais, sobre o mesmo fato. Assim, temos a sensação de que já temos todas as informações de que necessitávamos sobre o assunto.

O estereótipo não é necessariamente ruim ou uma interpretação errada. É uma interpretação superficial que ressalta as características mais recorrentes e marcantes, ou seja, uma interpretação caricaturada. Pode ser útil, por exemplo, quando reconhecemos rapidamente uma situação de perigo. É de suma importância, todavia, que tenhamos consciência das limitações dos estereótipos. Sem essa consciência, o estereótipo acaba tomando lugar da realidade e se torna preconceito e discriminação. Mais do que isso, o estereótipo tem a capacidade de construir uma identidade social ou uma representação de nós mesmos ou de grupos aos quais não pertencemos, como veremos a seguir. 


\subsubsection{Identidade/Representação}

Woodward (2000) postula que a identidade não se forma a partir daquilo que se é, mas sim, frente àquilo que não se é. Assim, quando alguém diz que é brasileiro, na verdade, o faz assumindo que não é norte-americano, inglês, argentino entre outros possíveis gentilícios. Para a autora, a questão de identidade abre margem para a discussão de outras sérias questões sociais, pois essa noção de diferença criada pela identidade ressalta que a diferença se sustenta na exclusão. Assim, a produção de identidade procura ressaltar apenas as diferenças, sugerindo que não existem intersecções entre os grupos. Por exemplo, ser indígena implicaria o não uso de tecnologias criadas pela sociedade não indígena, ou ainda, um modo de vida diferenciado, não tendo nada que o ligue à comunidade dita não indígena. Essa é uma interpretação bastante limitada de identidade.

Tal exclusão está fortemente ligada ao que van Dijk (2003) postula como a oposição “nós X eles". O “eu” só se constrói numa oposição ao outro. Normalmente, ainda, esse "eu” é construído em uma correspondência ao que se considera como padrão, enquanto o "outro" é colocado em uma classe de menor prestígio social. Por exemplo, nas dicotomias: homem/mulher, branco/negro, branco/indígena. Quando criamos, por meio da linguagem, essa oposição, na maioria das vezes procuramos ressaltar os pontos positivos do grupo ao qual pertencemos e os pontos negativos relacionados aos outros grupos. Mais do que criação linguística, Silva (2000) ressalta que a identidade e a diferença são formas de relações sociais que criam relações de poder e novas forças vetoriais, uma vez que tais identidades não têm apenas valor declarativo e sim performativo (além de dizer algo, o enunciado tem poder para efetivar ou realizar algo; aqui aludimos ao conceito de discurso na seção 1 deste capítulo). Por exemplo, quando um juiz profere a sentença "eu o declaro culpado", mais do que atribuir responsabilidade ao réu, ele está condenando-o a pagar algo à sociedade.

Assim, a noção de "outro" se torna indispensável para que se possa pensar na própria identidade. Como ressalta Bakhtin (1997, p. 55), “o homem tem uma necessidade estética absoluta do outro, da sua visão e da sua memória; memória que o junta e o unifica e que é a única capaz de lhe proporcionar um acabamento externo".

Atualmente, há o questionamento dos critérios definidores do que é "ser indígena". Para alguns, erroneamente, é inconcebível a noção de um indígena que se aproprie de tecnologias ou costumes dos não indígenas. Não são raros comentários como "Onde já se viu índio usando celular?", quando, na verdade, não se pensa em uma identidade dinâmica, capaz de remodelar suas fronteiras conforme necessidades histórico-culturais. 
Bauman (2005) defende, por exemplo, uma identidade fluida. Segundo o autor, não se pode pensar em uma identidade que seja fixa e indiferente às variações de tempo e espaço. A atual construção das identidades das mais de 200 comunidades indígenas brasileiras, por exemplo, não leva em consideração que esses povos tiveram seu território invadido, suas línguas e culturas silenciadas, sem contar as milhares de vidas ceifadas.

Como podemos perceber, a seguir, na fala de Daniel Caxibi, da nação Pareci (apud HECK \& PREZIA, 1999, p. 20), houve uma adaptação por parte dos indígenas ao novo modelo de vida que os cercava, porém processo semelhante não se verificou no sentido contrário:

\begin{abstract}
Percebo que as interpretações e comparações que nos fazem não passam de uma categoria de animais exóticos que habitam a selva. Tenho vontade de fazê-los compreender o meu mundo, assim como cheguei a compreender o mundo deles. Gostaria de dizer-lhes que faço parte de uma sociedade que possui normas de vivência harmônica entre os homens e a natureza. (...) Que possuímos nossos valores sociais, políticos, econômicos, culturais e religiosos, que adquirimos através dos tempos, de geração em geração.
\end{abstract}

Bauman (2005) utiliza a metáfora do quebra-cabeças para explicar como a identidade líquida moderna se configura: nossas identidades são como pequenas peças de um quebracabeças, porém nem todas as peças se encaixam perfeitamente. Algumas peças, inclusive, podem ser substituídas de acordo com nossas necessidades. Assim, essa remodelação das fronteiras identitárias das comunidades indígenas são um processo natural.

Cumpre lembrar que a identidade indígena não é única. Não estamos tratando aqui de uma única comunidade, mas sim dos mais de 200 povos indígenas que habitam o Brasil. Como ressalta Canclini (2001, p. 2115), a dificuldade em se determinar o que é identidade, nos dias atuais, reside no

\begin{abstract}
hábito de considerar os membros de uma sociedade como pertencentes a uma cultura homogênea e, por essa razão, terem apenas uma identidade coerente e distintiva. (...) Nossa identidade nacional não pode mais ser definida exclusivamente por um pertencimento a uma comunidade nacional. $\mathrm{O}$ alcance de objetos legítimos de estudo não deveria, portanto, limitar-se às diferenças, mas extender-se à hibridização. ${ }^{18}$ (tradução nossa)
\end{abstract}

\footnotetext{
${ }^{18}$ The habit of considering the members of a society as belonging to a homogenous culture and, for that reason, having one distinctive and coherent identity. (...) Our identity can no longer be defined by an exclusive belonging to a national community. The range of legitimate objects of study should therefore not be limited to differences, but should extend to hybridization. (CANCLINI, 2001, p. 2115)
} 
Além de pensar em uma identidade híbrida, podemos relacionar nosso trabalho ao conceito de representação social. Esse conceito está intimamente ligado ao que Durkheim chamava de representação coletiva. Para Alexandre (2001, p. 122) a representação social tem a ver com

[o] posicionamento e localização da consciência subjetiva nos espaços sociais, com o sentido de constituir percepções por parte dos indivíduos. Nesse contexto, as representações de um objeto social passam por um processo de formação entendido como um encadeamento de fenômenos interativos, fruto dos processos sociais no cotidiano do mundo moderno.

Ainda no que diz respeito às representações sociais, elas são, segundo Sêga (2000, p. 129),

\begin{abstract}
A elaboração por uma coletividade, sob indução social, de uma concepção de uma tarefa que não leva em conta a "realidade" do comportamento social, mas a organização do sistema cognitivo do grupo. (...) Se apresentam como uma maneira de interpretar e pensar a realidade cotidiana, uma forma de conhecimento da atividade mental desenvolvida pelos indivíduos e pelos grupos para fixar suas posições em relação a situações, eventos, objetos e comunicações que lhes concernem.
\end{abstract}

A partir das definições de identidade e de representação social apresentadas nesta seção, podemos nos questionar até que ponto as notícias veiculadas pela mídia influenciam na maneira que outros grupos enxergam as comunidades indígenas e até que ponto influenciam na percepção que as comunidades indígenas constroem de si mesmas.

Assim, neste trabalho, temos como objetivo averiguar, por meio da análise das estruturas linguísticas, qual a identidade que se cria em relação aos povos indígenas na mídia impressa brasileira.

\title{
2.2 Discurso e texto
}

A relação entre o discurso e as estruturas de um texto é objeto de estudo tanto no cenário nacional quanto internacional. No cenário internacional, van Dijk se destaca pelo trabalho desenvolvido sobre o racismo contra minorias, principalmente o que está presente no discurso midiático. Por esse motivo, nosso trabalho é também guiado por sua proposta de análise de estruturas, como veremos mais adiante.

Segundo van Dijk (2003, p. 42), existem estruturas que são privilegiadas no discurso que se constrói para caracterizar grupos sociais. De acordo com o autor, a ideologia influencia não apenas aspectos como entonação, mas também a morfologia e a sintaxe. Tais estruturas já 
estão tão fortemente arraigadas no nosso dia a dia que não percebemos que não são estruturas escolhidas ao acaso; muitas vezes, inclusive, acabamos reproduzindo tais discursos e perpetuando justamente o que van Dijk denomina de racismo do dia a dia.

\begin{abstract}
Racismo é um sistema de desigualdade étnico-racial, reproduzido por práticas sociais discriminatórias, incluindo o discurso a nível local (micro), e por instituições, organizações e relações entre grupos a nível global (macro), cognitivamente fundamentado em ideologias racistas. (tradução nossa) ${ }^{19}$
\end{abstract}

(VAN DIJK, 2003, p. 41)

Ao defender que o racismo se apoia cognitivamente em ideologias, van Dijk estabelece um diálogo com a Linguística Centrada no Uso, principalmente com a teoria da mesclagem conceptual no que tange à formação de identidades e representações. Duque \& Costa (2012, p. 109) explicam que:

\begin{abstract}
A mesclagem conceptual (conceptual blending) é uma teoria geral da cognição que descreve a capacidade humana de imaginar identidades entre conceitos e integrá-los para criar e formar novos modelos de pensamento e ação. Esse processo atesta nossa atuação criativa a partir de conhecimentos e experiências anteriores, transformandoos a cada nova situação. Identidade, integração e imaginação são, de acordo com os autores [Fauconnier, 1994, 1997 e Fauconnier e Turner, 2002], operações humanas universais que tornam o homem capaz de realizar a mesclagem conceptual. A relação entre as estruturas preexistentes de conhecimento (frames e esquemas imagéticos) e os espaços temporariamente criados durante o processo de construção de sentido ajuda-nos a compreender os aspectos da construção do significado local, constituindose diferentemente a cada interação, e a dinâmica da produção e da compreensão discursivas.
\end{abstract}

Procuramos, portanto, neste trabalho, analisar quais seriam as estruturas gramaticais privilegiadas pela mídia impressa para construir o discurso sobre o indígena brasileiro. Quando possível, indicaremos, por meio do protocolo de análise (conferir capítulo metodológico), quais estruturas correspondem às categorias já identificadas por van Dijk. São essas categorias que passamos a apresentar brevemente a seguir.

\title{
2.2.1 Tópico
}

Uma das primeiras categorias apresentadas por van Dijk é o tópico, que é caracterizado semanticamente. Tópico é "sobre o que se fala". O conceito fica mais claro quando pensamos

\footnotetext{
19 Racism is a system of ethnic/racial inequality, reproduced by discriminatory social practices, including discourse at the local (micro) level, and by institutions, organizations and overall group relations on the global (macro) level, and cognitively supported by racist ideologies. (VAN DIJK, 2003, p. 41)
} 
em uma manchete. É esperado que, com a leitura de uma manchete, possamos saber qual será o principal tema abordado em uma notícia. Em consequência disso, notamos que muitos leitores adquirem o hábito de apenas ler a manchete e, às vezes, o lead para separar as matérias que lhes interessam. Estudos mostram, inclusive, que o racismo é menos topicalizado do que assuntos que mostram crimes, contravenções e problemas causados por grupos minoritários. Aqui, portanto, levantaremos quais assuntos são preferencialmente topicalizados quando se trata da temática indígena.

Esse conceito de tópico difere do conceito apresentado no capítulo anterior. Lá, vimos que tópico é a informação sentencial compartilhada entre os interlocutores (a informação conhecida, velha) em oposição à informação nova (o foco). O tópico aqui refere-se ao assunto global e mais importante de um dado discurso. Ele é representado por uma proposição. É de natureza semântico-discursiva. Entendemos, por fim, que ambas as perspectivas sobre tópico são válidas e complementares. Tanto metodológica quanto analiticamente, fazemos a identificação do tópico pragmático e do tópico semântico-discursivo.

\subsubsection{Implicações e pressuposições}

Implicações e pressuposições estão intimamente ligadas aos princípios da Linguística Centrada no Uso, pois são as maneiras que nosso sistema cognitivo encontra para preencher informações que estão faltando (em muitos, casos propositadamente). O discurso, na perspectiva que aqui adotamos, é baseado em modelos mentais que temos sobre eventos, e apenas parte da informação é expressa nesses modelos. Daí que a parte da informação que falta é inferida com base em um modelo de discurso que possuímos ou em nosso conhecimento sociocultural (VAN DIJK, 2003, p. 46).

Logo, as pressuposições dependem do conhecimento de mundo compartilhado pelo leitor e pelo escritor. Esses modelos mentais são construídos a partir de experiências prévias ou de informações que recebemos para conduzir nossa linha de pensamento (cf. frames, no capítulo 1, por exemplo). Manipular o caminho que o leitor seguirá é, segundo van Dijk, uma forma muito utilizada pelos meios de comunicação ao fazerem com que falsas pressuposições soem como verdadeiras. Por exemplo: "a elevada taxa de criminalidade entre imigrantes preocupa o governo". Tal afirmação pressupõe a veracidade da informação: existe uma elevada taxa de criminalidade entre imigrantes. Há muitos significados implícitos aí: essa criminalidade existe em que segmento de imigrantes? Empregados e/ou desempregados? Jovens e/ou adultos? Em que contextos? Essas e outras perguntas ficam sem resposta explícita no discurso. As respostas implícitas, infelizmente, tendem a colocar os imigrantes em posição negativa. 
Assim, o jornal pode deixar lacunas de propósito, convidando o leitor a tirar suas próprias conclusões, evocando o senso comum e seus estereótipos. No exemplo anterior, podemos pensar que o leitor imediatamente procurará uma solução adequada. Ora, se a taxa de criminalidade é alta, deve-se proibir a entrada de imigrantes. A comunidade local deve ser protegida deles.

Discursos a que tivemos acesso anteriormente são usados como modelo para preencher as lacunas em novos discursos. Assim, quando lemos alguma manchete que, por exemplo, não nos diz qual etnia estava envolvida no fato notíciado, preenchemos esse vazio com o indígena genérico, pois poucas pessoas estão familiarizadas com a diversidade e singularidade das comunidades indígenas.

Como pretendemos que esta pesquisa seja um estudo crítico, comungamos com van Dijk (2003, p. 47) quando ele afirma que “(...) tornar significados implícitos em uma sentença ou em um fragmento de texto pode ser um poderoso instrumento de estudos críticos" (tradução nossa). E com ele também concordamos sobre o fato de que "a opção de expressar uma informação ou deixá-la explícita não é ideologicamente neutra" (tradução nossa) ${ }^{20}$. Acrescentamos, ainda, que deixar informações implícitas também não é ideologicamente neutro como veremos no capítulo 4.

\subsubsection{Coerência Local}

A coerência é, de acordo com van Dijk (2012b), o discurso enquanto sequência de proposições que têm relação entre si. Para o usuário da língua, um discurso é coerente se, a partir dele, é possível criar um modelo mental. A coerência local, portanto, se constrói quando as estruturas escolhidas para construir um discurso seguem um modelo.

Quando se fala de coerência local, mais do que falar sobre a coerência de um texto, no geral, estamos falando da coerência entre o encadeamento de fatos notíciados. A coerência pode ser um importante mecanismo de controle ideológico. Um exemplo mais concreto de como essa estrutura pode ser utilizada para gerar preconceito é quando se diz "ele é indígena, mas gosta de trabalhar". A falsa ideia de que há uma incoerência entre ser indígena e gostar de trabalhar é construída na maneira como se monta essa adversativa no enunciado. Como afirma van Dijk (2003, p. 48), “(...) coerência é relativa, e essa relatividade também tem uma dimensão

\footnotetext{
${ }^{20}$ In ideological discourse analysis making explicit the meanings implied by a sentence or text fragment may be a powerful instrument of critical study. The option to express information or leave it explicit, is not ideologically neutral, however. (VAN DIJK 2003, p. 47)
} 
ideológica" (tradução nossa). ${ }^{21}$ Meu modelo mental sobre os indígenas é que vai reconhecer ou não a coerência do exemplo anterior. Se penso, como pensa boa parte do senso comum, que índios são preguiçosos, a frase está perfeita. Mas se penso diferente, e é isso que de fato ocorre, a frase não tem o menor sentido, ou melhor, ela vai me soar ofensiva.

\title{
2.2.4 Sinônimos e paráfrases
}

Quando existem diferentes unidades lexicais (sinônimos) ou diferentes formulações para fazer referência a determinado grupo (paráfrases), esses termos ou formulações não serão escolhidos ao acaso. Eles estão carregados de ideologia. Assim, por exemplo, usar o termo "comunidade indígena" é ideologicamente diferente da escolha do termo "tribo" ou "indiaiada". van Dijk explica que não existem sinônimos perfeitos. O sinônimo nada mais é do que a variação de uma unidade lexical que depende do contexto, e cada uso pode corresponder a implicações ideológicas diferentes.

Que sinônimos são usados pelos jornais em análise nesta pesquisa para fazer referência aos índios brasileiros? Que tipo de implicação ideológica isso pode estar acarretando? Durante nossas análises, também buscamos verificar isso.

\subsubsection{Contraste}

A categoria chamada de contraste diz respeito à oposição, já mencionada, que se faz entre "nós" e “eles". Assim, uma polarização é lexicalmente implementada. Van Dijk explica que essa polarização cognitiva e discursiva pode assumir diferentes formas, mas, de maneira geral, essa polarização vai destacar as ideologias e atitudes dos grupos dominantes (atitudes e ideologias boas) e dominados (atitudes e ideologias ruins). A recorrência desse contraste nas estruturas gramaticais explicita a existência de um pertencimento que é defendido por um grupo dominante. Define-se quem faz parte do grupo e quem dele está excluído e, portanto, submisso.

\begin{abstract}
No discurso racista, por exemplo, nós encontramos muitas declarações ou histórias que são organizadas em forma de contraste: nós trabalhamos duro, eles são preguiçosos; eles conseguem emprego facilmente, e nós não, e por aí vai. É precisamente esse tipo de contraste discursivo recorrente que sugere que provavelmente também atitudes subjacentes e ideologias são representadas em termos polarizados, designando ingroups e outgroups. (tradução nossa) ${ }^{22}$
\end{abstract}

(VAN DIJK, 2003, p. 49)

Sem dúvida, os muitos e diversificados conflitos que os não-indígenas impuseram aos indígenas brasileiros ao longo de séculos geram contrastes, polarizações análogas ao da citação

\footnotetext{
21 (...) coherence is relative, and this relativity also has an ideological dimension. (VAN DIJK, 2003, p. 48)

${ }^{22}$ In racist discourse, for instance, we discover many statements and stories that are organized by this form of contrast: We work hard, They are lazy; They easily get jobs (housing etc), and we do not, and so on. It is precisely this kind of recurrent discursive contrast that suggests that probably also the underlying attitudes and ideologies are represented in polarized terms, designating ingroups and outgroups. (VAN DIJK, 2003, p. 49)
} 
anterior. E nas notícias de jornais como esse contraste se manifesta efetivamente?

\subsubsection{Exemplos e ilustrações}

Exemplos e ilustrações estão muito presentes em discursos racistas, sobretudo exemplos que dignificam o NÓS e desqualificam o ELES. É preciso que sejam dados ao interlocutor exemplos de histórias e episódios passados, para que se possam sustentar determinadas generalizações. Os exemplos têm papel de evidência ou prova da possível veracidade de uma dada proposição, racista especialmente (VAN DIJK, 2003, p. 50). Assim, em um discurso racista contra imigrantes, dar o exemplo de um atentado terrorista causado por um estrangeiro pode servir de argumento para um discurso que proponha a revisão das políticas de fronteira de um país ou mesmo de redefinição da constituição federal, como é o caso da França neste momento após os atentados de novembro de 2015.

Notícias ilustradas têm mais credibilidade e resguardam o jornal de acusações de racismo. Um exemplo claro disso é o uso de hiperlinks nas notícias veiculadas em meios eletrônicos. Em uma notícia que tenha como tema a invasão de indígenas, encontramos hiperlinks que nos remetem a outras invasões do passado, ou ainda, a notícias anteriores sobre essa mesma invasão.

\subsubsection{Disclaimers}

No dia a dia, ouvimos corriqueiramente construções de discurso que se iniciam com: "Nada contra eles, mas...”. A negação inicial aí é apenas aparente. Os chamados disclaimers são típicos de discursos preconceituosos, pois, aparentemente, negam o preconceito e colocam o falante numa posição de não culpado pelo que vai dizer. Normalmente, essas estruturas aparecem em primeiro plano, para evitar que o interlocutor possa fazer um juízo de valor negativo sobre quem fala. Há, ainda, casos em que o enunciador inverte a situação, culpando a vítima ou transferindo a culpa para terceiros. Van Dijk mostra claramente essa transferência de culpa em seus estudos de discurso racista contra imigrantes nas seguintes construções: "Não tenho nada contra imigrantes, mas meus clientes..." ou ainda em "Eles não são discriminados, na verdade, nós é que somos". Para o autor, há os seguintes tipos de disclaimers: 
Aparente pedido de desculpa: Me desculpe, mas...

Aparente esforço: Nós fizemos tudo que podíamos, mas...

Transferência: Eu não tenho problema com eles, mas...

Inversão, culpando a vítima: ELES não são discriminados, mas NÓS é que somos!

(tradução nossa) $)^{23}$

(VAN DIJK, 2003, p. 50)

\subsubsection{Modalidade}

Modalidades têm a ver com a maneira como representamos o mundo e seus eventos. van Dijk (2012b, p. 251) afirma que modalizações "como a necessidade, a probabilidade, a possibilidade, a obrigação, a permissão, assim por diante, criam novas proposições a partir de proposições". Assim, a proposição "Sue está na Grã-Bretanha” pode ser modalizada com o operador “É possível que” e crie a nova proposição "É possível que Sue esteja na GrãBretanha”.

van Dijk (2012b) lembra que a modalização não depende apenas dos modelos mentais, mas dos papéis que os atores sociais assumem no discurso. Assim, quando se quer colocar as intenções e ações do outro em questionamento, protegendo a face do enunciador, a modalização é uma boa estratégia.

A modalização é uma operação que resulta consequentemente em uma homogeneização do discurso com expressões como "sabe-se que" ou "é necessário que". Fazendo uso de construções como essas, temos a impressão de que a informação dada é de conhecimento e aceitação geral, para que não se oponha ao que se está lendo.

\subsubsection{Evidencialidade}

A evidencialidade é um conceito que está ligado às fontes da informação. O enunciador, como responsável pela fala, procura evidências para sustentar a sua tese ou para proteger a sua face. Normalmente, quando expressamos uma crença, é esperado que possamos fornecer evidências para aquilo que estamos afirmando. É uma forma de nos defendermos de quem discorda de nós.

van Dijk (2003, p. 52) lembra que as diferentes culturas têm suas próprias maneiras de

\footnotetext{
23 Apart from the well-known Apparent Denial, there are many types of disclaimers, such as: Apparent Concession: They may be very smart, but....

Apparent Empathy: They may have had problems, but... Apparent Apology: Excuse me, but... Apparent Effort: We do everything we can, but...

Transfer: I have no problems with them, but my clients...

Reversal, blaming the victim: THEY are not discriminated against, but WE are! (VAN DIJK, 2003, p. 50)
} 
avaliar ou selecionar quais argumentos são bons e quais deixam a desejar. $\mathrm{Na}$ sociedade contemporânea, no entanto, é amplamente aceito que a mídia é uma forte fonte de informação. Assim, é comum em diversas sociedades escutarmos o argumento de que "eu vi na TV que..." ou "estava no jornal hoje".

O jornal, sendo uma fonte de conhecimento legitimada pela sociedade, se torna uma importante fonte quando as discussões giram em torno de minorias étnicas. $\mathrm{O}$ autor afirma que, como é comum que jornais tragam a etnia para notícias sobre crimes, forma-se uma ideologia racista contra imigrantes na Europa, por exemplo. O argumento utilizado por racistas é que "você pode encontrar esses grupos nos jornais todos os dias, especialmente nas páginas policiais".

\subsubsection{Vaguidade}

A vaguidade é, segundo van Dijk (2012b), o recurso que se opõe à precisão. Somos vagos quando o assunto ressalta nossas características negativas, mas precisos quando estamos descrevendo as características negativas deles. Também podemos recorrer à vaguidade quando não sabemos precisamente a resposta para uma pergunta sem nos sentirmos diminuídos ou ignorantes.

Na mídia, encontramos alguns enunciados que parecem ser vagos, mas que, na verdade, estão camuflados para não haver a possibilidade de uma acusação de racismo. Nesses casos, as estratégias de implicaturas e pressuposições se tornam muito úteis. Na análise textual 2 (capítulo 4, seção 4.2.1), por exemplo, encontramos a informação de que "índios estavam armados com paus e flechas" em uma disputa contra madeireiros. E os madeireiros estavam armados com o quê? A informação fornecida aqui sobre eles (os índios) é mais precisa, enquanto os madeireiros são retratados de forma vaga.

Logo, concordamos com van Dijk (2003, p. 52) que "o gerenciamento da clareza ou vaguidão em um texto é uma poderosa ferramenta ideológica e política (...)". ${ }^{24}$

\subsubsection{Contexto}

Segundo van Dijk (2012b, p. 39), o sentido de contexto, quando aplicado à mídia, relaciona-se ao cenário social, político, financeiro e cultural. Segundo o autor, uma boa metáfora para elucidar esse contexto é pensar que o contexto é 'o 'fundo' para uma 'figura'

\footnotetext{
${ }^{24} \mathrm{~A}$ powerful political and ideological tool is the management of clarity and vagueness (...).(VAN DIJK, 2003, p.
} 52) 
que está em foco. Essa definição está bastante coerente com os princípios da Linguística Centrada no Uso (ou Cognitivo-Funcional), e por isso a adotamos nesta dissertação.

Nesse sentido, pensarmos no contexto em que a notícia foi escrita é de extrema relevância nos dias atuais, pois temos um cenário de constantes disputas de território e conflitos causados pelas construções de hidrelétricas em territórios indígenas, por exemplo, entre outros motivos. Para ilustrar isso, basta buscar na internet os termos mundurukú e hidrelétricas e serão encontradas várias notícias que dão conta da forte tensão que se opera em cenário nacional concernente à construção de hidrelétricas no território desse povo indígena no sudoeste do Pará. Para o governo, a construção das hidrelétricas trará benefícios; para o povo Mundurukú, trará prejuízos incalculáveis com relação à caça, pesca, perda de espaços sagrados, etc.

\subsubsection{Racismo do dia a dia}

Van Dijk (2003, p. 40) explica que o racismo já se tornou naturalizado quando relacionado a determinados grupos minoritários. Algumas piadas, denominações e formas de marginalizar já passam despercebidas e se tornaram parte do cotidiano linguístico-social. Apenas casos mais extremos são notados ou questionados. Para o autor, a legitimidade nesse racismo se baseia em um processo cognitivo de categorização que coloca o outro em uma categoria diferente do grupo dominante. Essa discriminação pode permear nossas práticas sociais, quando, por exemplo, não se dá emprego a uma pessoa por causa de sua origem étnica, baseando-se nas ideologias racistas compartilhadas pela sociedade.

Ainda segundo o autor, o tratamento negativo do outro, implica ao menos uma forma negativa de categorização. Ele nos dá o exemplo da imigração na Europa Ocidental e afirma que dois terços da população europeia é absolutamente contra a imigração. A base para esse racismo do dia a dia é cognitiva: impregnada de estereótipos, preconceitos, atitudes racistas naturalizadas e opiniões baseadas em ideologias racistas.

Racismo, de acordo com van Dijk, é um sistema de desigualdade étnica ou racial, reproduzida por práticas discriminatórias, incluindo o discurso, a nível micro, e instituições e organizações a nível macro, cognitivamente baseados em ideologias racistas. Percebemos que essa prática pode, por exemplo, estar presente no senso comum, na maneira como os indígenas são retratados na mídia impressa sob um falso pretexto de liberdade de expressão. No entanto, van Dijk (2012a, p. 46) ressalta que "a maior parte dessas elites [política, militar e econômica] é controlada pelo Estado ou por empresas particulares, que também apresentam restrições quanto a sua liberdade de articulação”. A voz da elite, segundo o autor, é a voz do patrão 
institucional ou empresarial, que se esconde em termos ideológicos de valor por meio da crença de que está exercendo sua liberdade de expressão, esquecendo-se, contudo, de que o discurso racista fere a dignidade do outro. Como esse racismo do dia a dia está sendo veiculado em nossas notícias sobre povos indígenas? Também buscaremos, no capítulo 4, responder a essa questão.

\subsubsection{Escolhas lexicais}

Para van Dijk, as escolhas lexicais podem expressar, principalmente, a distância que se quer colocar entre os grupos. A própria noção do "nós" versus "eles" mostra que as palavras têm o poder de segregar grupos. A pronominalização do outro grupo, por exemplo, pode mostrar que não há a necessidade de se nomear o que não pertence ao grupo dominante.

Em nossas análises (cf. capítulo 4), mostramos que a escolha de alguns verbos, por exemplo, assim como a despersonificação das comunidades indígenas, não se dá fortuitamente. A seleção lexical em notícias sobre os povos indígenas brasileiros é marcada por aspectos negativos e depreciativos.

\subsubsection{Modelos mentais}

Segundo van Dijk (2003, p. 21), existe uma memória social e uma memória individual. A última se desenvolve a partir de experiências pessoais, leituras e eventos que testemunhamos. Podemos chamar essa memória de modelo mental. O modelo mental é, portanto, subjetivo, pessoal e carregado de julgamentos de valor. É uma interpretação que o indivíduo faz da realidade.

Apesar de os modelos mentais serem particulares, compartilham também de fragmentos de ideologias dominantes na sociedade. Trazemos conosco conhecimentos sociais, valores e normas que guiam nossas atitudes como parte de uma sociedade. De acordo com van Dijk, isso até explica o porquê de, às vezes, fazermos ou dizermos coisas que não correspondem ao nosso desejo: sabemos que o modelo cognitivo e de participação social requer uma maneira cooperativa e competente de falar e agir.

Por terem também esse caráter social, os modelos mentais estão fortemente ligados aos estereótipos. A visão que a hegemonia dominante tem de determinado grupo influencia na forma como o indivíduo vai enxergar outro grupo social. Por exemplo, uma criança carregará com ela o modelo mental de "índio" que será construído com base no que lhes disserem seus pais, amigos, professores e a mídia. Essas perspectivas podem ser estereotipadas.

Os modelos mentais não são, portanto, uma categoria alheia às influências externas. 
Eles se (re)moldam constantemente, a partir de informações que temos no meio social.

Os modelos mentais são importantes para que façamos uma interpretação adequada dos discursos, sabendo quais informações estão explícitas e quais estão nas entrelinhas. Esse construto teórico é bastante similar aos modelos cognitivos, evidenciando o cunho cognitivista da análise do discurso feita por van Dijk. Isso só reforça a coerência teórica que adotamos aqui ao aproximar os campos teóricos em tela nesta pesquia.

\subsubsection{Topoi}

O termo topoi tem sua origem no pensamento Aristotélico e até hoje mantém seu significado original de "verdades comumente aceitas", ou melhor, "lugar-comum". Essas ideias aceitas não passam por um senso crítico, pois já viraram senso comum, adquirindo, equivocadamente, status de sabedorias compartilhadas em uma determinada sociedade. Apesar de apresentarem espaços para discussões, pois não são como dogmas, ou verdades absolutas, os topois são de difícil desconstrução, pois estão arraigados na base de uma sociedade e desconstruí-los significa tentar desconstruir o alicerce sobre o qual se apoiam as ideologias que constroem a sociedade.

De acordo com van Dijk (2003, p. 63), topois podem ser usados como argumentos padrão que os grupos dominantes utilizam para justificar a aversão aos outros grupos. Esses argumentos são tomados como verdades inquestionáveis e, dificilmente, explicitam a rejeição pelo outro. Segundo o autor, normalmente o que se encontra são estruturas como "não os negamos pelo que são (cor, cultura ou origem), por má vontade ou preconceito, mas porque não podemos apoiar isso".

As microestruturas apresentadas aqui são de grande relevância para nosso estudo, pois, como pudemos perceber, são estruturas extremamente sutis, mas com grande impacto na nossa leitura e formação ideológica. Elas também serão buscadas nas análises pretendidas no capítulo 4. A seguir, vamos falar dos meios de comunicação de massa, especialmente das notícias de jornal e de sua estruturação, pois entendemos que também devemos dar conta, minimamente, daquilo que está na base da construção modelar típica de uma notícia. Daí, poderemos verificar se essa construção está ou não atendendo a demandas ideológicas contrárias aos povos indígenas nos textos analisados no capítulo 4.

\subsection{Meios de comunicação de massa}

Os meios de comunicação de massa podem ser usados como forma de manutenção da hegemonia ideológica e discursiva, pois são formas simbólicas poderosas de construção da 
realidade. É por meio de jornais, programas televisivos, revistas, etc., que temos acesso às informações e construímos nossas opiniões sobre os mais diversos assuntos.

Motta (2002, p. 127) afirma que toda decisão de comunicar algo é, ao mesmo tempo, uma decisão de não comunicar outras coisas. A escolha da pauta, do que deve ser cortado ou não, bem como a escolha das fontes (evidencialidade) é fruto de condicionamentos políticos e ideológicos. Assim sendo, não há imprensa que se construa sem o poder e nem poder que se mantenha sem a imprensa.

Ainda de acordo com Motta (2002, p. 14):

A invenção da imprensa, de fato, coincide com a criação de nações e do Estado moderno e com o exercício do poder não apenas de forma coercitiva, pelo uso da força, mas por meio de formas mais sutis de coerção e de persuasão. A partir de então, a imprensa esteve sempre ligada à luta política.

Muitos estudiosos se debruçaram sobre a questão da representação de minorias na mídia (HARTMANN \& HUSBAND, 1974; UNESCO, 1974, 1977; HUSBAND, 1975; DOWNING, 1980; TROYNA, 1981; VAN DIJK, 1983a; entre muitos outros), especialmente no que diz respeito às notícias. Os resultados nos mostram uma realidade ainda muito preenchida pelo racismo. Segundo van Dijk (1988, p. 9), no que diz respeito à participação dessas minorias no discurso da mídia,

As notícias sobre eles são predominantemente negativas: crimes, conflitos, problemas sociais, drogas e as consequências negativas da imigração são percebidas pela maioria. Ou ainda, eles têm um papel passivo; as notícias são sobre as ações das autoridades por (ou contra) eles, ou de membros de grupos pertencentes à maioria branca. Sua opinião, mesmo que o assunto lhes diga respeito, é raramente pedida. Ao invés disso, uma minoria especialista branca é convidada a comentar os assuntos ou conflitos. ${ }^{25}$ (tradução nossa)

As minorias não são apenas representadas de maneira pejorativa, como também têm sua voz deslegitimada pelos mass media ${ }^{26}$ que prestigiam as classes sociais dominantes. Wolf

\footnotetext{
25 News about them is predominantly negative: crime, conflict, social problems, drugs, and the negative consequences of immigration as perceived by the majority. Or else they have a passive role; it is news about the actions of the authorities for (or against) them, or of members or groups from the white majority. Their opinion, even in matters that regard them directly, is seldom asked. Instead, white minority specialists are invited to comment on policy issues or conflicts (VAN DIJK 1988, p. 9)

${ }^{26} \mathrm{O}$ termo mass media surgiu no séc. XVIII e foi definido posteriormente por Nickolas Luhman como "as instituições que fazem uso da tecnologia para disseminar a comunicação", produzindo grandes quantidades de produtos para determinado público. A ideia geral é, portanto, atingir o maior número de pessoas numa quantidade
} 
(2009, p. 67) afirma que os meios de comunicação em massa têm três funções sociais independentemente de sua organização ou de sua ordem institucional.

(a) A atribuição de posição social e de prestígio às pessoas e aos grupos que são objeto de atenção por parte dos mass media (...). Esta função, que consiste em atribuir uma posição social, entra na atividade social organizada, legitimando certas pessoas, grupos e tendências sociais que recebem o apoio dos meios de comunicação em massa; (b) O reforço do prestígio social daqueles que se identificam com a necessidade, e o valor socialmente difundido, de serem cidadãos bem informados.; (c) (...) É claro que os meios de comunicação de massa servem para confirmar as normas sociais, denunciando seus desvios à opinião pública.

Levando em consideração as funções sociais apresentadas por Wolf, podemos dizer que a escolha pela análise de notícias se justifica pelo prestígio social que é atribuído a quem as lê. São as notícias, principalmente impressas/digitais, que formam a opinião de uma elite intelectual que acaba influenciando a opinião pública em geral.

Cumpre lembrar que, conforme dissemos na introdução deste trabalho, a notícia não é a realidade em si, mas sim uma tradução, uma interpretação dela. Wolf (2009, p. 68), inclusive, nos apresenta o que chama de "disfunção narcotizante" dos meios de comunicação em massa. Essa disfunção tem como ponto de partida um leitor apático e inerte que não percebe que se exime do agir. Procurando estar sempre bem informado, o leitor recorre aos mass media para construir o conhecimento do que acontece no dia a dia. Entretanto, o cidadão que não faz uma análise crítica do que lê acaba por confundir esse contato com o mundo político, econômico e social com a realidade. Não percebe que é necessário que se faça uma reflexão mais profunda e que o conhecimento não se dê apenas de forma passiva, mas que, também, deveria provocar uma reação.

A fim de entender melhor a notícia e analisá-la nesta dissertação sob o enfoque também jornalístico (além do linguístico), a seguir trataremos dos seguintes temas: agenda-setting e estrutura da notícia.

\subsubsection{Agenda-Setting}

O modelo do agenda-setting teve sua origem na década de 1960, nos Estados Unidos; no Brasil, se difundiu em 1995, a partir do trabalho intitulado Ética na comunicação, de Clóvis

menor de tempo. Utilizaremos esse termo, pois a notícia veiculada na internet é muito eficaz no que diz respeito a esse princípio. 
de Barros Filho. De acordo com Martino (2013, p. 207), "o modelo do agenda-setting prevê que os temas da agenda da mídia definem a agenda pública, isto é, passarão a ser discutidos pelas pessoas uma vez pautados pela mídia”. Ainda segundo o autor, o público tratará os temas abordados pela mídia de maneira horizontal, ou seja, ao mesmo tempo em que esses temas não são de preocupação profunda de ninguém, estão no discurso de todos.

Rodrigues (2002, p. 108) lembra que "o agenda-setting é o modelo que estuda a possibilidade de os media determinarem a agenda do público por meio do que destacam como prioridade". Ainda segundo a autora, a imprensa não é somente representante de uma sociedade civil; além de publicar o que considera de interesse público, a imprensa tem seus próprios interesses, uma parte dela alinhada com os interesses da elite.

De acordo com Wolf (2009, p. 145), “o pressuposto fundamental do agenda-setting é que a compreensão que as pessoas têm de grande parte da realidade social lhes é fornecida, por empréstimo, pelos mass media". Assim, os tópicos sobre os quais as pessoas lerão e formarão uma opinião são, em sua maior parte, definidos pelos meios de comunicação em massa, passando, portanto, por inúmeras seleções. A seguir trataremos especificamente da estrutura da notícia.

\subsubsection{A notícia e sua estrutura}

A notícia é um gênero textual característico do jornalismo. Ela se origina em uma tradição escrita, com uma relação de distanciamento entre quem escreve e quem lê. Por isso, é caracterizada como uma transmissão unilateral. Essa afirmativa é verdadeira se pensarmos no momento da produção da notícia. Mais tarde, porém, os leitores participarão do processo de recepção e, consequentemente, de interpretação, especialmente da interpretação dos implícitos, da retomada de frames, acionamento de pressupostos, etc.

Essa relação implica a noção de que os tempos da escrita, da produção da informação, do acontecimento e da leitura não coincidem. Mesmo assim, os jornais tendem a utilizar na notícia o que chamamos de presente histórico. Sendo a notícia escrita no presente, o jornalista é capaz de trazê-la para mais perto do leitor. Charaudeau (2013, p. 114) considera que esse processo de construção da notícia se dá em um duplo processo, que, na verdade, é um contrato social da comunicação. $\mathrm{O}$ acontecimento (fato que pode vir a se tornar notícia) se encontra em um estado bruto e deve ser interpretado para um estado de "mundo midiático", ou seja, deve se adequar aos manuais de redação. A instância midiática constrói a notícia, prevendo quais as possíveis interpretações daquilo que escreve e daquilo que gostaria de que fosse entendido pela instância receptora. Essa, por sua vez, vai reinterpretar a notícia de acordo com seu 
conhecimento de mundo e fazer sua própria leitura.

Tal processo seria representado pela figura abaixo:

Figura 2 - O contrato social da comunicação

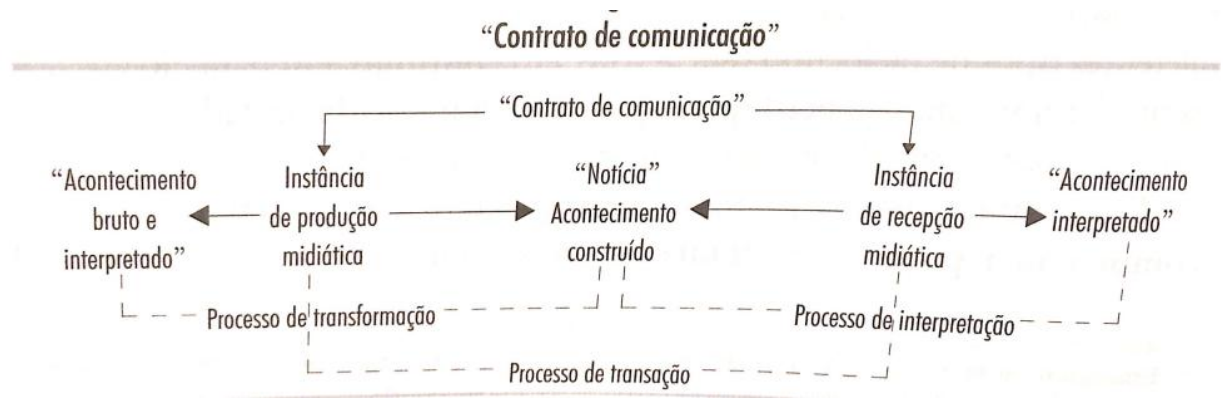

(Fonte: CHARAUDEAU, P. Discurso das mídias. São Paulo: Contexto, 2013, p.114.)

No entanto, a própria estrutura da notícia exerce uma função cognitiva que guia o leitor no sentido em que se espera que o texto seja lido. A manchete, por exemplo, resume o que o enunciador considera ser essencial. Nesse sentido, Elhajji et al. (2012, p. 12) afirmam que,

(...) por ser o primeiro conteúdo a ser lido na matéria, a manchete auxilia na construção de um conjunto de referências que de certa forma monitoram as possíveis interpretações daquele texto. Os títulos teoricamente são compreendidos como resumos ou apresentações daquilo que de mais importante será notíciado.

Cabe, então, nos perguntarmos quais os sentidos trazidos pelas manchetes sobre as comunidades indígenas que vão guiar nossa leitura do texto. van Dijk (2012a, p. 145) salienta que "esses sumários típicos das notícias [manchetes] são diferentes para as minorias quando comparados com as notícias que tratam de membros do grupo dominante". O autor ressalta ainda que, quando se trata de minorias étnicas, há uma lista de tópicos preferidos pelos meios de comunicação, por exemplo: diferenças culturais, crimes étnicos típicos, desvios de comportamento, entre outros.

Martino (2013, p. 39) sublinha que

A literatura acadêmica e prática sobre jornalismo explica que o título de uma notícia deve mostrar a principal informação de maneira rápida, curta e simples. A manchete 
deve concentrar o máximo de dados em um mínimo espaço, ressaltando o evento principal (...) O estudo da produção de notícias, no entanto, mostra como é possível desmontar essa posição e observar que as manchetes sobre o mesmo tema, publicadas em jornais diferentes, criam imagens completamente diferentes da mesma situação.

Assim, se pensarmos que muitas pessoas leem apenas as manchetes como forma de se manterem informadas, notamos que as manchetes, mais do que conduzir como interpretaremos um texto, podem conduzir nossa interpretação de mundo. Há farta literatura sobre os efeitos que têm as manchetes na compreensão e interpretação de um texto, mas não a traremos à baila por falta de tempo (cf. por exemplo, Kozminsky (1977) e Lemarié, Lorch Jr. \& Péry-Woodley $(2012))^{27}$.

Após a manchete, vem o lead. Segundo Bonini (2002, p. 80), “o lead é a abertura da matéria. Nos textos noticiosos, deve incluir, em duas ou três frases, as informações essenciais que transmitam ao leitor um resumo completo do fato". Ainda segundo o autor, é altamente recomendável que o lead seja escrito de maneira clara, preferencialmente na ordem direta e que seja objetivo.

Lage (apud ARCE, 2009, p. 7) assim define o lead:

Lead é a abertura de uma notícia: proposição completa, constituída de sujeito, verbo e complementos e circunstâncias, que se inicia pela notação mais importante ou interessante e que pode apresentar-se, no nível de sua realização sintática, por um ou mais períodos no mesmo parágrafo lógico.

Acerca do lead, Arce ( 2009, p. 10) diz ainda que a função de quem se propõe a fazer uma análise é proceder a uma leitura técnica do documento (no caso, das notícias), determinar sua tematicidade, identificar conceitos-chave, traduzir esses conceitos, de forma que, quando for necessário, o usuário possa recuperar aquela informação com a maior precisão possível.

Assim, inferimos que a função do lead defendida pela autora vai ao encontro do que define Bonini. O problema está na ideologia por trás dessa elaboração. Quem escolhe quais informações são fundamentais para a compreensão do texto? Quais estruturas serão privilegiadas para transmitir tais informações?

A estrutura da notícia se baseia em questões fundamentais, tais como: o que, quem,

\footnotetext{
${ }^{27}$ KOZMINSKY, E. Altering comprehension: The effect of biasing titles on text comprehension. Memory \& Cognition, 5, 482-490. 1977.

LEMARIÉ, J.; LORCH JR, R. F.; PÉRY-WOODLEY, M-P.: Understanding How Headings Influence Text Processing. Discours [En ligne], 10 | 2012, mis en ligne le 16 juillet 2012, consulté le 10 février 2016. URL : http://discours.revues.org/8600.
} 
quando, onde, como e por quê. A notícia é construída, metaforicamente, como uma pirâmide invertida. No topo, encontramos as informações que são consideradas de maior relevância. Em seguida, em ordem decrescente de importância, as demais informações são apresentadas. Assim, é natural que afirmemos que a manchete, o lead, bem como o primeiro parágrafo são aqueles que vão conduzir os sentidos da leitura. Bonini (2002, p. 162) desenvolveu o seguinte esquema que representa a estrutura da notícia:

Figura 3 - Esquema da notícia

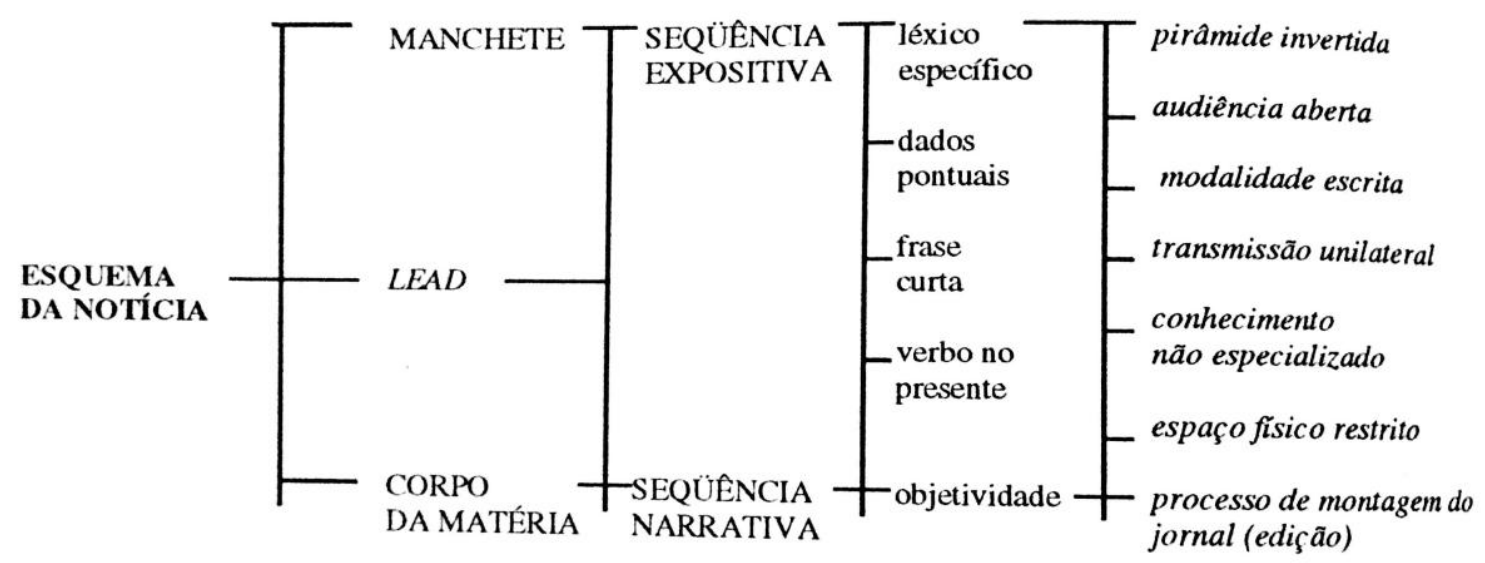

(Fonte: BONINI, A. Gêneros textuais e cognição. Florianópolis: Insular, 2002, p 162.)

O esquema acima resume muito bem a estrutura do texto (notícia) trabalhado nesta dissertação e suas especificidades. Partindo de um ponto de vista cognitivista, entendemos que tanto a macroestrutura da notícia quanto a microestrutura contribuem para a formação de novos significados ou a manutenção de sentidos estereotipados, senso comum, preconceito e até racismo contra povos indígenas. Infelizmente, é o que mostram as análises feitas no capítulo 4. 


\subsection{Critérios de noticiabilidade}

Após a reflexão acerca da estrutura da notícia, devemos nos perguntar quais acontecimentos são selecionados para se tornar notícia. Podemos pensar, por exemplo, que determinados tópicos (cf. seção 2.2.1 deste capítulo) devem ser selecionados em detrimento de outros. Quais seriam, então, os critérios para definir o que vira notícia?

Segundo van Dijk (apud SOUSA, 2000, p. 42), “a organização da produção jornalística privilegiaria acontecimentos produzidos/definidos por figuras públicas e setores preponderantes da vida social e política, reproduzindo uma estrutura social favorável a essas elites". Podemos inferir, portanto, que a mídia estabelece, sim, critérios para definir quais grupos sociais seriam notícia e como seriam representados. Hall (1993, p. 228) lembra que "os media definem para a maioria da população quais os acontecimentos significativos que ocorrem e, também, oferecem poderosas interpretações de como compreender esses acontecimentos".

De acordo com Giacomeli (2008, p. 15),

Pesquisadores não só do meio jornalístico, mas também sociólogos, psicólogos e até antropólogos debruçaram-se sobre o assunto [noticiabilidade]. Formularam-se várias teorias para explicar o uso dos conceitos de noticiabilidade, também chamados de "valores-notícia".

Sobre noticiabilidade, Aldé et al (2005, p. 187) afirmam: “Acreditamos que, em certa medida, este discurso influi sobre os critérios que adotam no momento de escolher pautas e fontes, atribuir relevância editorial, descartar possíveis temas, problemas e matérias como não dignos de serem publicados".

O quadro abaixo elenca os principais critérios de noticiabilidade utilizados pelos jornais, dentre eles, destacamos os critérios definidos por Wolf e Bond por tratarem de questões de interesse nacional, injustiças que provocam indignação e a importância que o indivíduo envolvido na notícia tem na sociedade. Acreditamos que tais critérios refletem nas escolhas das estruturas verbais que farão parte das manchetes e das notícias, além de serem, possivelmente, os critérios que melhor abarcam as questões indígenas na mídia naciona 
Quadro 3 - Critérios de Noticiabilidade

\begin{tabular}{|c|}
\hline \\
\hline eler: novidade, proximidade geografica, proeminéncia e negativismo. \\
\hline oximidade geográfica, impacto e conflito pessoal. \\
\hline Bond: referente à pessoa de destaque ou personagem público (proeminência); incomu \\
\hline $\begin{array}{l}\text { (raridade); referente ao governo (interesse nacional); que afeta o bolso (interesse } \\
\text { pessoal/econômico); injustiça que provoca indignação (injustiça); grandes perdas de } \\
\text { vida ou bens (catástrofe); consequências universais (interesse universal); que provo- } \\
\text { ca emoção (drama); de interesse de grande número de pessoas (número de pessoas } \\
\text { afetadas); grandes somas (grande quantia de dinheiro); descoberta de qualquer setor } \\
\text { (descobertas/invençōes) e assassinato (crime/violência). }\end{array}$ \\
\hline $\begin{array}{l}\text { Galtung e Ruge: freqüência, amplitude, clareza ou falta de ambigủidade, relevância, } \\
\text { conformidade, imprevisão, continuidade, referência a pessoas e naçóes de elite, }\end{array}$ \\
\hline $\begin{array}{l}\text { composiçăo, personificaçăo e negativismo. } \\
\text { Golding-Elliot: drama, visual atrativo, entretenimento, importância, proximidade, } \\
\text { brevidade, negativismo, atualidade, elites, famosos. }\end{array}$ \\
\hline $\begin{array}{l}\text { Gans: importância, interesse, novidade, qualidade, equilibrio. } \\
\text { Warren: atualidade, proximidade, proeminência, curiosidade, conflito, suspense, }\end{array}$ \\
\hline emoçăo e consequiências. \\
\hline $\begin{array}{l}\text { Hetherington: importância, drama, surpresa, famosos, escândalo sexual/crime, nú- } \\
\text { mero de pessoas envolvidas, proximidade, visual bonito/atrativo. }\end{array}$ \\
\hline $\begin{array}{l}\text { Shoemaker et all: oportunidade, proximidade, importância/impacto, consequiência, } \\
\text { interesse, conflito / polêmica, controvérsia, sensacionalismo, proeminência, novi- }\end{array}$ \\
\hline dade/curiosidade/raro. \\
\hline $\begin{array}{l}\text { Wolf: importância do individuo (nivel hierárquico), influência sobre o interesse na- } \\
\text { cional, número de pessoas envolvidas, relevância quanto à evoluçăo futura. }\end{array}$ \\
\hline $\begin{array}{l}\text { Erbolato: proximidade, marco geográfico, impacto, proeminēncia, aventura/con- } \\
\text { flito, consequiências, humor, raridade, progresso, sexo e idade, interesse pessoal, } \\
\text { interesse humano, importância, rivalidade, utilidade, politica editorial, oportunida- }\end{array}$ \\
\hline de, dinheiro, expectativa/suspense, origi-nalidade, culto de heróis, descobertas/ \\
\hline
\end{tabular}

(Fonte: SILVA (2008a, p.102))

Os valores-notícia, conforme aponta Mota (2012), levam a uma construção hegemônica do conhecimento, pois a voz por trás da notícia é de alguém que está em uma posição de poder 
elevada. Os jornais, segundo a autora, se tornam porta-vozes e estabelecem uma primeira interpretação do tema abordado, que servirá de guia para interpretações futuras. Novas interpretações culturais serão fixadas ou reforçadas de forma desigual, contribuindo para a manutenção de uma hegemonia.

Nessa linha de raciocínio, inclui-se a seguinte indagação: os critérios de noticiabilidade potencialmente reforçam o preconceito aos indígenas, fazendo com que esses sejam retratados apenas em situações extremas ou de maneira negativa

\subsection{Resumo do capítulo}

Neste capítulo, apresentamos conceitos presentes nos Estudos Críticos do Discurso e na comunicação de massa, os quais serão essenciais para a análise feita mais adiante, no capítulo 4. É somente por meio do conhecimento do que se chama de discurso, ideologia, identidade, estereótipo e das microestruturas de van Dijk que poderemos fazer uma leitura mais profunda das notícias que são veiculadas atualmente. Assim como ter noção de como se dá o processo de produção de uma notícia escrita nos revela importantes pistas sobre a representação que se constrói no discurso hoje dominante. 


\section{Capítulo 3 - Percursos metodológicos}

\subsection{Introdução}

Neste capítulo, apresentamos os caminhos que trilhamos para analisar as notícias. Vimos, nos capítulos anteriores, que a própria organização das partes de uma notícia não se dá ao acaso: a manchete, o lead e a organização das informações em forma de pirâmide invertida mostram claramente que o texto atende a anseios extralinguísticos (cf. seção 2.3.2). Assim, nossa escolha por esse tipo de fonte de informação requer uma metodologia de trabalho específica. Uma metodologia que também nos possibilite identificar as estratégias de voz/valência e todos os demais recursos usados na elaboração do discurso que podem ser acionados para construir determinados sentidos em detrimento de outros.

Começaremos apresentando e justificando nossa escolha pela pesquisa documental e qualitativa (seção 3.1). Em seguida, mostraremos como escolhemos os jornais que serão trabalhados (seção 3.2). Logo após, justificaremos os limites temporais que estabelecemos; a princípio, pode-se pensar que estamos trabalhando com um período demasiadamente longo, mas veremos que não é o caso (seção 3.3). E, por fim (seção 3.4), mostraremos o protocolo de análise textual que criamos para aplicar os construtoss e recortes teóricos apresentados nos capítulos 1 e 2 .

\subsection{A pesquisa documental e qualitativa}

Goldenberg (2002, p. 14) afirma que: “o que determina como trabalhar é o problema que se quer trabalhar: só se escolhe o caminho quando se sabe aonde se quer chegar”. Assim, como nosso trabalho se propõe a analisar notícias veiculadas pela mídia brasileira, iniciaremos fazendo uma pesquisa documental.

Como postulamos que a notícia representa um discurso ideológico dominante (ao mesmo tempo em que o constitui) e em constante construção histórica, os documentos escritos são uma importante fonte para a compreensão de uma construção identitária social sobre os povos indígenas brasileiros. A notícia, como já afirmamos, não é a realidade em si, mas uma representação dela; portanto, ela nos diz muito sobre as atividades humanas e os valores de determinada sociedade. van Dijk (1985, p. 77) considera que os sentidos, temas e tópicos são estruturas cognitivas desenvolvidas pelo escritor ou pelo leitor. Representam o que é entendido como importante, como a realidade é compreendida e como os acontecimentos são armazenados em nosso sistema cognitivo. Assim, para o autor, esse sistema de crenças 
influencia, de fato, na macroestrutura de um texto.

Como afirma Cellard (2008, p. 295),

(...) o documento escrito constitui uma fonte extremamente preciosa para todo pesquisador nas ciências sociais. Ele é, evidentemente, insubstituível em qualquer reconstituição referente a um passado relativamente distante, pois não é raro que ele represente a quase totalidade dos vestígios da atividade humana em determinadas épocas. Além disso, muito frequentemente, ele permanece como o único testemunho de atividades particulares ocorridas num passado recente.

O mesmo autor afirma ainda que a pesquisa documental se justifica por auxiliar na observação de conceitos, mentalidades, práticas e outros. A observação de tais mentalidades só é possível porque um documento é uma fonte primária de informação. Isso quer dizer que é considerado um documento aquilo que ainda não recebeu trato analítico por nenhum outro autor, fato indispensável para classificar uma pesquisa como documental. O pesquisador, nesse tipo de trabalho, desenvolve uma relação direta com o seu objeto de estudo.

Mas, afinal, o que entendemos por documento neste trabalho? Ao recorrermos ao dicionário Houaiss da língua portuguesa, em sua versão digital 3.0 (2009), encontramos as seguintes acepções sobre o termo documento: “1. declaração escrita que se reconhece oficialmente como prova de um estado, condição, habilitação, fato ou acontecimento; 2 . texto ou qualquer objeto que se colige como prova de autenticidade de um fato e que constitui elemento de informação (...)". Em tese, estamos entendendo que as notícias podem ser elas mesmas tomadas como documentos que comprovam/evidenciam a visão distorcida que a mídia reproduz e sustenta sobre os povos indígenas na sociedade brasileira.

Silva (2007, p. 51) faz uma importante consideração acerca da notícia como discurso.

Na narrativa parece que não existe locutor ou falante, e, assim, os acontecimentos parecem evoluir e falar por si próprios. Já no discurso se apresenta uma enunciação que supõe sempre um locutor/falante e um ouvinte/leitor. Há, por parte do locutor, uma vontade de influenciar o ouvinte. No discurso não são apenas os acontecimentos contados que importam, mas como o narrador organizou e ordenou seu relato para o ouvinte.

Ainda segundo Silva (2007, p. 51), “enquanto a linguagem, de modo geral, é a argamassa da sociedade e das relações jurídicas e sociais entre os cidadãos, a linguagem vai construindo o arcabouço moral, psicológico, ideológico e social de uma determinada comunidade".

Definimos, também, este estudo como uma pesquisa de cunho qualitativo. De acordo 
com Denzin \& Lincoln (apud CRESWELL, 2014, p. 49),

Pesquisa qualitativa é uma atividade situada que localiza o observador no mundo. A
pesquisa qualitativa consiste em um conjunto de práticas materiais interpretativas que
tornam o mundo visível. Essas práticas transformam o mundo. Elas transformam o
mundo em uma série de representações (...). Nesse nível, a pesquisa qualitativa
envolve uma abordagem interpretativa e naturalística do mundo. Isso significa que os
pesquisadores qualitativos estudam coisas dentro dos seus contextos naturais,
tentando entender, ou interpretar, os fenômenos em termos dos significados que as
pessoas lhes atribuem.

Por se tratar de uma pesquisa que busca compreender as possíveis interpretações, significações e representações presentes em um texto jornalístico, entendemos que essa é uma pesquisa que, de alguma forma, traz o nosso mundo material para o centro de nossas discussões. Ao invés de analisar um grande número de notícias neste curto período de mestrado, queremos que fique claro como cada nível de análise importa para a construção das representações que temos/fazemos, atualmente, das comunidades indígenas. O qualitativo aqui não será baseado, entretanto, em nossas interpretações pessoais, mas nas análises linguísticas a que submetemos cada notícia e na comparação das regularidades estruturais e funcionais encontradas nelas (cf. seção 3.4). Para tanto, adotamos um método bastante analítico, com camadas de análise que vão da sintaxe ao discurso, chegando até mesmo ao estrato constitutivo da própria notícia em termos jornalísticos (cf. seção 3.4).

Ainda sobre a pesquisa qualitativa, Schwandt (2006, p. 194) retoma a afirmação de Gadamer (1970) de que a compreensão não é uma atividade humana isolada, mas uma estrutura básica da experiência de vida. Assim, para entendermos uma ação em particular, temos que compreender os significados que constituem a ação. Indo ao encontro dos pressupostos da Linguística Centrada no Uso e dos Estudos Críticos do Discurso, só podemos compreender um evento (como a notícia) se conhecermos o contexto ao qual ele pertence.

Para Schwandt (2006), a lingua(gem) e a razão são ferramentas ou instrumentos de controle para construirmos, ordenarmos e descobrirmos o mundo. Essa é uma noção fundamental para que possamos falar da metodologia de pesquisa qualitativa que o autor chama de Construtivismo Social. Sobre isso, Schwandt (2006, p. 197) afirma que

Inventamos conceitos, modelos e esquemas para conferirmos sentido às nossas experiências, e continuamente testamos e modificamos essas construções à luz de nossas novas experiências. Além disso, há uma dimensão histórica e sociocultural inevitável nessas construções. Nós não construímos nossas interpretações de maneira isolada, mas em contraste com conhecimentos, práticas e a língua compartilhados, etc. ${ }^{28}$ (tradução nossa)

\footnotetext{
28 We invent concepts, models, and schemes to make sense of experience, and we continually test and modify these constructions in the light of new experience. Furthermore, there is an inevitable historical and sociocultural
} 
Assim, para o Construtivismo Social interessa estudar como os enunciados funcionam, demonstrando que seu trabalho diz respeito a um conjunto de práticas sociais e estratégias retóricas que têm um importante papel no discurso.

Veremos a seguir, como se deu a escolha dos jornais.

\subsection{A escolha dos jornais}

Analisamos, nesta pesquisa, notícias veiculadas pelos jornais $O$ Globo/G1 (http://g1.globo.com) e Folha de S. Paulo (http://www.folha.uol.com.br) em suas versões online. Como já dito na introdução deste trabalho, acreditamos que esses jornais são fontes de informação bastante acessadas, principalmente pela elite intelectual do país, que é, também, formadora de opinião, uma vez que a mídia escrita ainda é muito valorizada em nossa sociedade.

A Folha de S. Paulo, por exemplo, começou a circular sob o título de Folha da Noite em 1921. Somente em 1960, é adotado o nome que conhecemos hoje em dia. Segundo o site da empresa:

A Folha estabelece como premissa de sua linha editorial a busca por um jornalismo crítico, apartidário e pluralista. Essas características, que norteiam o trabalho dos profissionais do Grupo Folha, foram detalhadas a partir de 1981 em diferentes projetos editoriais.

De acordo com dados divulgados na plataforma on-line do próprio jornal (http://www1.folha.uol.com.br/poder/2014/03/1433100-folha-e-o-maior-jornal-do-brasil-nasdiferentes-plataformas-aponta-ivc.shtml $>>$ acesso em 28/12/2015), a Folha é o jornal que tem o maior número de edições pagas, o maior número de acessos e mais de um terço de suas vendas é de edições virtuais. As análises empreendidas por nós no capítulo 4 permitirão ao leitor averiguar se, de fato, a Folha cumpre sua meta de ser crítica, apartidária e pluralista...

Em segundo lugar, ainda de acordo com a notícia citada acima, o jornal com maior circulação em território nacional é $O$ Globo, que surgiu em 2000 como o portal on-line do grupo Globo. Em 2006, houve a criação do portal G1, como portal de notícias, que reúne o conteúdo da Globo, Globo News, das rádios Globo e CBN, dos jornais O Globo e Diário de São Paulo, além das revistas Época, Globo Rural e outras. A necessidade da criação de um portal que reunisse todo esse conteúdo advém da era tecnológica na qual nos encontramos.

dimension to this construction. We do not construct our interpretations in isolation but against a backdrop of shared understandings, practices, language and so forth. (SCHWANDT, 2006, p. 197) 
Segundo o portal de $O$ Globo:

\begin{abstract}
Ao mesmo tempo, porém, ela [internet] obriga a que todas as empresas que se dedicam a fazer jornalismo expressem de maneira formal os princípios que seguem cotidianamente. O objetivo é não somente diferenciar-se, mas facilitar o julgamento do público sobre o trabalho dos veículos, permitindo, de forma transparente, que qualquer um verifique se a prática é condizente com a crença. As Organizações Globo [hoje Grupo Globo], diante dessa necessidade, oferecem ao público o documento "Princípios Editoriais das Organizações Globo" [hoje "Princípios Editoriais do Grupo Globo"].
\end{abstract}

Analisamos, nesta dissertação, principalmente as notícias veiculadas nas seguintes partes de $O$ Globo: Primeira página, Editoria, Opinião, Colunas, O país, Economia, O mundo, Sociedade. Do jornal Folha de S. Paulo, buscaremos notícias em: Primeira página, Editorial, Opinião, Colunas, Tendências/debates, Poder, Mercado, Mundo, Cotidiano.

As seções indicadas acima foram escolhidas por representarem os temas compilados pela Empresa Brasil de Comunicação (EBC) e disponibilizados ao público em geral. As notícias encontradas nesse apanhado feito pela EBC podem estar disponíveis tanto na versão impressa do jornal quanto na eletrônica. Para este estudo, escolhemos as que podem ser acessadas online. Essas notícias foram coletadas no site da EBC (http://clipping.radiobras.gov.br), que reúne as informações diretamente dos jornais em tela e de outras fontes. $\mathrm{Na} \mathrm{EBC}$, não se registra tudo o que é publicado, porque o serviço oferecido é o de clipping, justamente uma seleção daquilo que é mais relevante política e economicamente. ${ }^{29}$ Também buscamos outras notícias que não foram compiladas pela EBC. Para essa busca, entramos nos sites da Folha de S. Paulo e G1 e procuramos pelas palavras-chave "índio", " indígenas" e "tribo".

Segundo Cruvinel (2013, p. 29)

Em 2006, surgiu o movimento pela criação da TV Pública, capitaneado pelo Ministério da Cultura, então ocupado por Gilberto Gil. Resultou no Fórum e na promessa do presidente Lula de implantar esta emissora se fosse reeleito. No segundo mandato, seu ministro da Comunicação Social, Franklin Martins, recebeu a missão de implantar a emissora. Criou um grupo técnico, que elaborou as bases da Medida Provisória (MP) 398, depois convertida pelo Congresso na Lei 11.652/2008, a lei da EBC. A MP autorizou o Governo a criar uma nova empresa de comunicação, a EBC, que passaria a ser responsável pela gestão de todos os canais consignados para a própria União.

Escolhemos jornais de alcance nacional para que pudéssemos compreender qual é o

29 A EBC oferece serviço de clipping (apanhado das principais notícias) dos principais jornais do Brasil desde 1985 por meio de mídia impressa e desde 2003 oferece o serviço eletrônico. 
discurso generalizado sobre os povos indígenas, independentemente da maior ou menor presença de indígenas na cidade ou no estado em que o leitor esteja inserido.

Nossa intenção não é analisar um grande número de notícias, tendo em vista que os textos analisados nos trazem uma riqueza ímpar de detalhes que devem ser destrinchados minuciosamente. Como veremos a seguir, a própria escassez de notícias não nos permitiria analisar um grande número de textos.

Logo, neste primeiro momento, vamos analisar com bastante rigor um grupo de notícias, testando nossa proposta de protocolo de análise (cf. seção 3.4) e levantamento de indícios que permitem dizer o que a mídia (re)afirma sobre os nossos povos indígenas. Vamos tomar este trabalho como piloto para outras etapas posteriores ao mestrado.

\subsection{O período analisado}

Escolhemos analisar o período de 01 de janeiro 2012 a 31 de janeiro de 2015, por se tratar de um período recente, que pode retratar o pensamento contemporâneo. Esse pode parecer um período longo a ser analisado, porém, ao acessarmos a base de dados da EBC e inserirmos as palavras-chaves "índio", "indígena" e "tribo", nos deparamos com a seguinte realidade: 
Tabela 1 - Resultados da pesquisa sobre notícias envolvendo a temática indígena no jornal $O$ Globo O Globo

('16' resultados em '5' seções)

\section{O País (10)}

\begin{tabular}{|c|c|c|}
\hline relevância & data & título \\
\hline 10,75 & $11 / 04 / 2013$ & Índios desocupam hotel na Bahia após chegada da PF \\
\hline 8,85 & $28 / 03 / 2013$ & $\begin{array}{l}\text { PF apura denúncia de discriminação racial contra indios em escola do Mato } \\
\text { Grosso do Sul }\end{array}$ \\
\hline 7,84 & $09 / 04 / 2013$ & Índios ocupam hotel de luxo na Bahia e cobram demarcação de terras \\
\hline 7,15 & 04/03/2012 & Conectado na preservação da Amazônia \\
\hline 5,95 & $16 / 06 / 2013$ & 'Hoje não se engana mais o nosso povo', diz líder terena \\
\hline 5,85 & $16 / 06 / 2013$ & Aldeias do Vale do Tapajós têm 13 mil indígenas \\
\hline 5,46 & $19 / 04 / 2013$ & Um grito de guerra suspenso no campo \\
\hline 3,79 & 04/08/2013 & Silenciosos, os Awá se confundem com a mata \\
\hline 3,45 & 04/08/2013 & 'Estamos bravos. Assim eles vão nos matar' \\
\hline 3,12 & 04/08/2013 & A tragedia do desmatamento atinge a terra e o céu \\
\hline
\end{tabular}

Suplemento (1)

relevância data título

$9,04 \quad 23 / 07 / 2014 \quad$ Gripe derruba indios no Acre

\section{Economia (2)}

$\begin{array}{lll}\text { relevância data } & \text { título } \\ 8,82 & 24 / 06 / 2013 & \text { Líderes indigenas liberam biólogos reféns } \\ 7,71 & 24 / 02 / 2013 & \text { Funai administra recursos milionários }\end{array}$

Rio (2)

$\begin{array}{lll}\text { relevância data } & \text { título } \\ 8,17 & 20 / 10 / 2012 & \text { 'Tribo Maracanā' promete lutar por terreno }\end{array}$

$\begin{array}{lll}8,17 & 20 / 10 / 2012 & \text { 'Tribo Maracanā' promete lutar por terreno } \\ 3,85 & 25 / 05 / 2012 & \text { Indios chegam ao Rio para montar aldeia }\end{array}$

Sociedade (1)

relevância data título

6,19 05/09/2014 Contra invasor, justiça com as próprias mãos

(Fonte: $<<$ http://clipping.radiobras.gov.br $>>$ acesso em 20/07/2015)

Tabela 2- Resultados da pesquisa sobre notícias envolvendo a temática indígena no jornal Folha de $S$. Paulo

Folha de S. Paulo

('1' resultados em '1' seçöes)

Poder (1)

$\begin{array}{lll}\text { relevância data } & \text { título } \\ 6,58 & 06 / 09 / 2014 & \text { Indios criam 'exército' contra madeireiros }\end{array}$

(Fonte: $<<$ http://clipping.radiobras.gov.br $>>$ acesso em 20/07/2015)

A informação de que há apenas uma notícia disponível no clipping da Folha de S. Paulo é gritante. Ao mesmo tempo, essa mesma informação comprova a nossa hipótese de que os indígenas pertencem a um grupo que não é considerado relevante no cenário político, 
econômico e cultural. Há apenas uma notícia, de temática negativa (criação de exército contra madeireiros), considerada digna de ser lida por autoridades que compõem o governo.

Nas tabelas anteriores, observamos também um critério denominado relevância. Segundo a jornalista Letícia Sallorenzo (cp.), o número faz referência às vezes em que a palavra-chave procurada ocorre no texto e em qual parágrafo ela se encontra. Se a palavra estiver no início do texto, a relevância será maior; porém, se estiver no final, o número tende a cair. Tal fato é coerente com a própria estrutura da notícia em forma de pirâmide invertida (cf. 2.2.2), pois as informações mais importantes aparecem sempre no topo da notícia. A relevância varia numericamente de 0 a 10.

No período analisado, encontramos, portanto, oficialmente, 17 notícias com a temática indígena. Um número relativamente pequeno, o que pode ser interpretado como um indício de que esse é um segmento social que não ocupa espaço na mídia, ou cuja voz é silenciada.

\subsection{O protocolo de análise textual}

A partir dos recortes teóricos já expostos nos capítulos 1 e 2, elaboramos um protocolo de análise composto por camadas de análise que contemplam desde os conceitos propostos pela Linguística Funcional Centrada no Uso, passando pelos conceitos escolhidos dos Estudos Críticos do Discurso, chegando até a estrutura da notícia e os critérios de noticiabilidade. A seguir, mostramos um resumo do protocolo: 
Quadro 4 - Procolo de análise textual

Texto a ser analisado

(a notícia na íntegra)

A. Eixo analítico: Linguística Cognitivo-Funcional (Linguística Centrada no Uso)

A.1 Voz (stricto sensu e lato sensu)/ Valência verbal

A.2. Relações gramaticais/ Papéis Semânticos/ Papéis Pragmáticos

A.3. Metáforas e metonímias

A.4. Iconicidade Diagramática

A.5. Frames

B. Eixo analítico: Discurso e Ideologia

Escolhas lexicais

Topoi

Modalização

Evidencialidade

Tópico

Contexto

Racismo do dia a dia

Implicações/Pressuposições

Sinônimos/Paráfrases

Disclaimers

Coerência local

Contraste

Exemplos/ilustrações

Vaguidade

Modelos mentais

Modelo de dominação de Thompson

\section{Eixo analítico: Comunicação}

C.1. Qual(is) o(s) critério(s) de noticiabilidade ressaltado(s)?

Raridade

Interesse nacional

Interesse pessoal/econômico

Catástrofe

Interesse universal

Injustiça

Crime/violência

Drama

Proeminência do indivíduo na sociedade

C.2. Estrutura da notícia

Manchete

Lead

Informações primárias/iniciais

Informações secundárias/finais

Caderno/Local da publicação 
Esse protocolo foi aplicado na análise dos dados basicamente da seguinte forma:

1. cada notícia foi escrutinada, analisando-se o que está previsto em cada eixo acima previsto;

2. em cada eixo, foi feita uma síntese específica do que se analisou naquele eixo;

3. ao final da aplicação do protocolo sobre uma dada notícia, fizemos uma síntese global do que se encontrou naquela notícia;

4. após analisarmos as notícias selecionadas, seguindo-se os passos acima, apresentamos uma síntese geral, buscando mostrar qual representação os jornais em análise fazem dos povos indígenas brasileiros.

Esse protocolo de análise procurou contemplar os aportes teóricos que foram previstos nesta pesquisa e mostrar como acontece a relação entre estrutura e sentido, e como isso se reflete na formação/manutenção de ideologia no texto jornalístico. No próximo capítulo, apresentaremos as análises das notícias feitas de acordo com esse protocolo.

\subsection{Resumo do capítulo}

Apresentamos aqui nossos princípios metodológicos: a pesquisa qualitativa e documental. Também mostramos e justificamos os jornais que seriam pesquisados e trouxemos os motivos que nos levaram a pesquisar um dado período cronológico. O mais importante deste capítulo foi a apresentação do protocolo de análise textual, o qual conjugou os recortes teóricos previstos nos capítulos 1 e 2, e nos possibilitou tornar concreta a análise das notícias, a fim de atingirmos os objetivos previstos nesta dissertação. 


\section{Capítulo 4 - Análises das notícias}

\subsection{Introdução}

Nos capítulos anteriores, vimos os aportes teóricos que deram subsídios para nossa pesquisa. Neste capítulo, analisamos 4 textos reais, selecionados aleatoriamente dentre os textos encontrados no banco de dados da EBC e nas pesquisas nos próprios portais de notícia, com o intuito de verificar quais estruturas linguísticas são eleitas pela grande mídia quando as comunidades indígenas viram o centro da notícia. Ao final de cada notícia, fazemos uma breve síntese com os pontos que mais nos chamaram a atenção. Por último, apontamos as principais estruturas linguísticas que se repetem nos textos analisados e como elas contribuem para uma reafirmação da posição dos indígenas na nossa sociedade. A seguir, apresentamos as notícias e suas análises. 


\title{
4.1. Análise Textual 1 - Notícia 1
}

\section{Notícia 1}

\author{
Índios invadem fazendas em Itapebi, um homem morre e PF assume caso \\ Grupo de 20 indigenas invadiu fazenda \\ Indígenas afirmam que estão lutando pela recuperação de suas terras. \\ Cerca de 20 indígenas da tribo Tupinambá invadiram três fazendas no município de Itapebi, a 130 km de Porto Seguro, na Bahia, de acordo com \\ informações da Polícia Federal (PF). Segundo o órgão, os índios invadiram três fazendas e incendiaram uma das casas da sede. Uma pessoa foi \\ encontrada morta no local, com um tiro no pescoço. \\ Ainda de acordo com a PF, os indígenas confessaram que incendiaram a casa e negam envolvimento com a morte do homem. $O$ suspeito do crime ainda não \\ foi identificado. As polícias Civil, Militar e o Departamento de Polícia Técnica (DPT), foram acionados para investigar o ocorrido. \\ Os índios invadiram a fazenda no domingo (19) e nesta quarta-feira (22) eles deixaram o local. Segundo a polícia, em depoimento, eles disseram que vivem em \\ uma mata ao redor da fazenda e afirmam que estão lutando pela recuperação de suas terras. \\ Os fazendeiros foram ouvidos pela polícia na terça-feira (21), e afirmaram que os índios invadiram a propriedade e mataram animais da \\ fazenda. Já os índios disseram aos agentes que os fazendeiros responderam a invasão com violência. \\ Os policiais investigam se pistoleiros estariam envolvidos com os índios. A Fundação Nacional do Índio (FUNAI) está acompanhando todo o caso. \\ Segundo o delegado da Polícia Federal em Porto Seguro, Eriosvaldo Renovato Dias, a situação já se normalizou no local. \\ (Fonte: http://g1.globo.com/bahia/notícia/2014/01/indios-invadem-fazendas-em-itapebi-um-homem-morre-e-pf-assume-caso.html > (com acesso em julho de 2015)
}




\section{A - Eixo analítico: Linguística Cognitivo-Funcional (Linguística Centrada no Uso) (Notícia 1)}

\section{A.1 Voz (stricto sensu e lato sensu)/ Valência verbal (Notícia 1)}

\begin{tabular}{|c|c|c|c|c|}
\hline Enunciados & Voz /ordem & $\begin{array}{l}\text { Valência } \\
\text { Sintática }\end{array}$ & $\begin{array}{l}\text { Valência } \\
\text { Semântica }\end{array}$ & Análise/Síntese \\
\hline $\begin{array}{l}\text { Índios invadem fazendas em } \\
\text { Itapebi }\end{array}$ & $\begin{array}{l}\text { Voz ativa; ordem } \\
\text { direta }(\mathrm{SVO}) .\end{array}$ & 2 & 2 & $\begin{array}{l}\text { Uso da voz ativa com sujeito agente prototípico: humano, } \\
\text { com volição, com alto grau de controle e que provoca } \\
\text { mudanças em um paciente inanimado, com função de objeto } \\
\text { direto. }\end{array}$ \\
\hline Um homem morre & $\begin{array}{l}\text { Voz ativa; ordem } \\
\text { direta }(\mathrm{SV}) .\end{array}$ & 1 & 1 & $\begin{array}{l}\text { A opção por um verbo intransitivo não permite ao leitor ter } \\
\text { acesso direto à causa da morte. Logo, ele é levado a inferir } \\
\text { essa informação no contexto: os índios teriam sido os } \\
\text { responsáveis pela morte do homem devido à invasão. } \\
\text { Constrói-se aí uma coerência interna, nos moldes de Van } \\
\text { Dijk (cf. seção } 2.2 .3 \text { e Eixo B abaixo). }\end{array}$ \\
\hline PF assume o caso & $\begin{array}{l}\text { Voz ativa; ordem } \\
\text { direta (SVO). }\end{array}$ & 2 & 2 & $\begin{array}{l}\text { Uso da voz ativa, com sujeito prenchido por uma entidade, } \\
\text { um representante importante da instituição Justiça (a PF) } \\
\text { Evoca-se uma entidade que traz a noção de justiça e que } \\
\text { sugere gravidade ao caso. O que se entende dessa sequência } \\
\text { de três orações é: houve invasão de índios, houve morte de } \\
\text { um homem (provavelmente um não-índio morto por eles), e } \\
\text { a PF entrou para investigar a invasão e a morte do homem. }\end{array}$ \\
\hline $\begin{array}{l}\text { Grupo de } 20 \text { indígenas } \\
\text { invadiu fazenda no domingo, } \\
\text { no interior da Bahia. }\end{array}$ & $\begin{array}{l}\text { Voz ativa; ordem } \\
\text { direta (SVO). }\end{array}$ & 2 & 2 & $\begin{array}{l}\text { Há novamente o uso do verbo invadir, com todos os seus } \\
\text { argumentos preenchidos. O sujeito é "grupo de } 20 \\
\text { indígenas", o objeto direto é "fazenda", o aspecto e } \\
\text { perfectivo, objeto individuado, enunciado afirmativo. Logo, } \\
\text { há um alto grau de transitividade nos termos de Hopper \& } \\
\text { Thompson (1980). }\end{array}$ \\
\hline
\end{tabular}




\begin{tabular}{|c|c|c|c|c|}
\hline $\begin{array}{l}\text { Uma pessoa foi encontrada } \\
\text { morta no local, com um tiro no } \\
\text { pescoço. }\end{array}$ & $\begin{array}{l}\text { Voz passiva com } \\
\text { omissão do } \\
\text { agente; ordem } \\
\text { direta }(\mathrm{SV}) .\end{array}$ & 1 & \begin{tabular}{l}
\multicolumn{2}{c}{2} \\
(a passiva \\
prevê um \\
agente, \\
muito \\
embora ele \\
não seja, \\
sintatica- \\
mente, \\
obrigatório.
\end{tabular} & $\begin{array}{l}\text { A voz passiva cria, nesse caso, um quadro mental estático, } \\
\text { não imaginamos o momento da ação, quando a pessoa é } \\
\text { morta; imaginamos o momento em que ela é encontrada. } \\
\text { Não se cita quem a matou. Mas há implicaturas/inferências } \\
\text { aí. Também não fica clara a identidade da pessoa, mas } \\
\text { certamente ela não é um índio, o que faz pensar que os índios } \\
\text { não são colocados no mesmo patamar que as pessoas. }\end{array}$ \\
\hline
\end{tabular}

A.2. Relações gramaticais/ Papéis Semânticos/ Papéis Pragmáticos (Notícia 1)

\begin{tabular}{|c|c|c|c|c|c|}
\hline Enunciados & $\begin{array}{l}\text { Argumentos/ } \\
\text { Adjuntos }\end{array}$ & $\begin{array}{l}\text { RG ou } \\
\text { Adjuntos }\end{array}$ & $\begin{array}{c}\text { Papel } \\
\text { Semântico }\end{array}$ & $\begin{array}{c}\text { Papel } \\
\text { Pragmático }\end{array}$ & Análise/Síntese \\
\hline $\begin{array}{l}\text { Índios invadem fazendas em } \\
\text { Itapebi }\end{array}$ & $\begin{array}{l}\text { Arg1: índios } \\
\text { Arg2: fazendas } \\
\text { Adjunto: em } \\
\text { Itapebi }\end{array}$ & $\begin{array}{l}\text { Arg1: Sujeito } \\
\text { Arg2: Objeto } \\
\text { direto } \\
\text { Adjunto } \\
\text { adverbial }\end{array}$ & $\begin{array}{l}\text { Arg1: Agente } \\
\text { Arg2: Paciente } \\
\text { Adj: lugar }\end{array}$ & $\begin{array}{l}\text { Arg1: Tópico } \\
\text { Arg2: Foco }\end{array}$ & $\begin{array}{l}\text { Há um alinhamento prototípico, com sujeito } \\
\text { agente e tópico, enquanto o foco recai sobre } \\
\text { um objeto, paciente e inanimado. Os índios } \\
\text { são sujeito, são tópico e agente, mas de um } \\
\text { verbo com semântica negativa. }\end{array}$ \\
\hline Um homem morre & $\begin{array}{l}\text { Arg. único: } \\
\text { um homem }\end{array}$ & Sujeito & Experienciador & Tópico & $\begin{array}{l}\text { O sujeito é experienciador, humano e } \\
\text { tópico. No entanto, o homem é sujeito de } \\
\text { um verbo que não implica volição e que, no } \\
\text { contexto, evoca possivelmente um } \\
\text { assassinato e não uma morte natural. }\end{array}$ \\
\hline PF assume o caso & $\begin{array}{l}\text { Arg1: } P F \\
\text { Arg2: o caso }\end{array}$ & $\begin{array}{l}\text { Arg1: Sujeito } \\
\text { Arg2: Objeto } \\
\text { direto }\end{array}$ & $\begin{array}{l}\text { Arg1: Agente } \\
\text { Arg 2: Paciente }\end{array}$ & $\begin{array}{l}\text { Arg1: Tópico } \\
\text { Arg2: Foco }\end{array}$ & $\begin{array}{l}\text { Há um alinhamento prototípico: sujeito, } \\
\text { agente, tópico; porém, é interessante notar } \\
\text { que não se tem um agente prototípico: não é } \\
\text { humano. Usa-se aí uma metonímia, } \\
\text { evocando-se a instituição (o todo) e não um } \\
\text { indivíduo particular. (cf. Eixo A.3 Notícia } \\
\text { 1) }\end{array}$ \\
\hline
\end{tabular}




\begin{tabular}{|c|c|c|c|c|c|}
\hline $\begin{array}{l}\text { Grupo de } 20 \text { indígenas } \\
\text { invadiu fazenda no } \\
\text { domingo, no interior da } \\
\text { Bahia. }\end{array}$ & $\begin{array}{cc}\text { Arg1: } & \text { Grupo } \\
\text { de } & 20 \\
\text { indigenas } \\
\text { Arg2: fazenda } \\
\text { Adj. 1: } & \text { no } \\
\text { domingo } & \\
\text { Adj. 2: } & \text { no } \\
\text { interior } & \text { da } \\
\text { Bahia } & \end{array}$ & $\begin{array}{l}\text { Arg1: Sujeito } \\
\text { Arg2: Objeto } \\
\text { Adj1: } \\
\text { adverbial } \\
\text { Adj2: } \\
\text { adverbial }\end{array}$ & $\begin{array}{l}\text { Arg1: Agente } \\
\text { Arg2: Paciente } \\
\text { Adj1: Tempo } \\
\text { Adj2: Lugar }\end{array}$ & $\begin{array}{l}\text { Arg1: Tópico } \\
\text { Arg2: Foco }\end{array}$ & $\begin{array}{l}\text { Há um alinhamento prototípico: o sujeito é } \\
\text { agente e tópico. O objeto direto é fazenda } \\
\text { que sofre mudanças de estado (um paciente, } \\
\text { portanto). Nesse momento, ocorre a } \\
\text { especificação de quantos indígenas estavam } \\
\text { envolvidos, quando ocorreu o fato e quantas } \\
\text { fazendas foram invadidas; na verdade, fora } \\
\text { apenas uma, ao contrário do que foi } \\
\text { afirmado na manchete, embora essa } \\
\text { vaguidade sobre o número de indígenas e de } \\
\text { fazendas seja uma constante no texto (cf. } \\
\text { eixo B Notícia } 1 \text {, subseção vaguidade). }\end{array}$ \\
\hline $\begin{array}{l}\text { Uma pessoa foi encontrada } \\
\text { morta no local, com um tiro } \\
\text { no pescoço. }\end{array}$ & $\begin{array}{l}\text { Arg. único: } \\
\text { uma pessoa } \\
\text { Adj1: no local } \\
\text { Adj2: } \\
\text { tiro } \\
\text { Adj3: } \\
\text { pescoço }\end{array}$ & $\begin{array}{l}\text { Arg. único: } \\
\text { Sujeito } \\
\text { Adj1, } 2 \text { e 3: } \\
\text { Adverbiais }\end{array}$ & $\begin{array}{l}\text { Arg. único: } \\
\text { Paciente } \\
\text { Adj1: lugar } \\
\text { Adj2: } \\
\text { instrumento } \\
\text { Adj3: lugar }\end{array}$ & $\begin{array}{ll}\text { Arg. único: } \\
\text { Tópico }\end{array}$ & $\begin{array}{l}\text { O alinhamento entre argumento } \\
\text { sujeito/tópico e papel semântico não é } \\
\text { prototípico. Temos um sujeito/tópico que é } \\
\text { paciente. Não se cita quem é o agente, } \\
\text { embora sua existência esteja } \\
\text { prevista/pressuposta na valência semântica } \\
\text { do verbo (voz passiva). Localiza-se o tiro } \\
\text { para exaltar a violência. Quais os possíveis } \\
\text { motivos? Inferências acionadas no } \\
\text { imaginário coletivo sobre os índios } \\
\text { brasileiros a serem discutidas nos eixos B e } \\
\text { C abaixo. }\end{array}$ \\
\hline
\end{tabular}




\section{A.3. Metáforas e metonímias (Notícia 1)}

\begin{tabular}{|c|c|c|}
\hline $\begin{array}{l}\text { Metáfora } \\
\text { ou } \\
\text { Metonímia }\end{array}$ & Enunciados & Análise/Síntese \\
\hline Metáfora & $\begin{array}{l}\text { Índios invadem fazendas; homem morre; } \\
\text { os índios invadiram três fazendas e incendiaram uma das } \\
\text { casas da sede; uma pessoa foi encontrada morta no local, } \\
\text { com um tiro no pescoço; os índios invadiram a fazenda no } \\
\text { domingo (19); em depoimento, eles disseram que vivem em } \\
\text { uma mata ao redor da fazenda e afirmam que estão lutando } \\
\text { pela recuperação de suas terras; os fazendeiros (...) } \\
\text { afirmaram que os indios invadiram a propriedade e } \\
\text { mataram animais da fazenda; }\end{array}$ & $\begin{array}{l}\text { Invadir um lugar + incendiar + lutar por terra }+ \text { matar }+ \text { confessar }+ \\
\text { pistoleiros = metáfora conceitual da GUERRA } \\
\text { O motivo da ação dos índios foi dado no lead e no final da notícia: } \\
\text { recuperar a terra perdida. Mas isso não foi o tema/tópico real da notícia. } \\
\text { Ela se concentrou em construir a metáfora da GUERRA, em que os } \\
\text { índios são selvagens, que estão em guerra contra os civilizados. A ideia } \\
\text { de selvagem aparece implicitamente em toda a notícia e, explicitamente, } \\
\text { no final: “(...) vivem em uma mata ao redor da fazenda”. Isso sugere que } \\
\text { eles são como animais não domesticados, que vivem no mato, na mata. } \\
\text { Esse tipo de notícia contribui muito para a manutenção do estereótipo } \\
\text { do índio selvagem e que pode guerrear contra os não índios, por meio } \\
\text { de invasões, incêndios, assassinatos e associação com criminosos } \\
\text { (pistoleiros). }\end{array}$ \\
\hline Metonímia & Índios invadem fazendas em Itapebi & $\begin{array}{l}\text { Ao usar o termo "índios", a notícia dá a entender que eram muitos; o } \\
\text { que não se confirma no corpo da notícia, quando descobrimos que se } \\
\text { tratava de } 20 \text { tupinambás. O termo "índios" é o nome de uma categoria } \\
\text { composta de } 200 \text { etnias no Brasil. A escolha do termo que indica o todo } \\
\text { no lugar da parte (uma etnia específica) pode ser interpretado como } \\
\text { forma de generalizar a informação, de homogeneizar esses povos, } \\
\text { massificando-os, tratando-os como um tipo só. } \\
\text { O uso de "fazendas" no plural também generaliza. Além de indicar que } \\
\text { é mais de uma fazenda, a princípio, pode dar ao leitor a falsa impressão } \\
\text { de que são todas as fazendas da cidade, dando uma amplitude muito } \\
\text { maior ao problema. }\end{array}$ \\
\hline
\end{tabular}




\begin{tabular}{|l|l|l|}
\hline Metonímia & PF assume o caso & $\begin{array}{l}\text { A polícia federal é uma entidade que evoca o conceito de justiça, sendo } \\
\text { parte desse conceito. Essa parte é, amplamente, vista como atuante em } \\
\text { crimes graves. Logo, pressupõe-se que houve um crime grave. }\end{array}$ \\
\hline
\end{tabular}

\section{A.4 . Iconicidade Diagramática (Notícia 1)}

\begin{tabular}{|l|l|l|}
\hline \multicolumn{1}{|c|}{ Enunciados } & Tipificação & Análise/Síntese \\
\hline $\begin{array}{l}\text { Grupo de 20 indígenas invadiu } \\
\text { fazenda no domingo, no interior da } \\
\text { Bahia. }\end{array}$ & $\begin{array}{l}\text { Quantidade, } \\
\text { complexidade }\end{array}$ & $\begin{array}{l}\text { Ao tornar o sujeito um constituinte maior, parece haver a intenção de manter a } \\
\text { coerência com a ideia de grande quantidade expressa antes com relação ao mesmo } \\
\text { referente, no caso "índios"; embora o jornal tenha sido obrigado a revelar quantos } \\
\text { índios eram, apenas 20 e não muitos como o plural inicialmente dado sugere, ele } \\
\text { optou por "grupo de 20 indígenas”, o que pode levar à mesma leitura inicialmente } \\
\text { dada: foram muitos. O recurso a um sintagma nominal complexo estruturalmente } \\
\text { falando é, para nós, uma estratégia para manter a leitura de "muitos” expressa no } \\
\text { início da notícia. Na sequência, com relação ao mesmo referente, o jornal constrói } \\
\text { outro sintagma nominal sujeito de grande extensão: “Cerca de 20 indígenas da tribo } \\
\text { Tupinambá,, e o leitor pode ser induzido, outra vez, a pensar em uma grande } \\
\text { quantidade de índios. }\end{array}$ \\
\hline
\end{tabular}




\section{A.5 Frames (Notícia 1)}

\begin{tabular}{|l|l|l|}
\hline \multicolumn{1}{|c|}{ Enunciados } & \multicolumn{1}{c|}{ Frames } & \multicolumn{1}{c|}{ Análise/Síntese } \\
\hline Índios invadem fazendas em Itapebi. & INVASÃO INDÍGENA & $\begin{array}{l}\text { Índios são invasores de propriedades privadas. Ocorre aí a inversão dos valores } \\
\text { históricos: as terras antes eram dos índios; eles foram expulsos e massacrados; mas, se } \\
\text { tentam recuperar o que era deles, são tomados como invasores. Mantém-se o } \\
\text { estereótipo. }\end{array}$ \\
\hline $\begin{array}{l}\text { Um homem morre. } \\
\text { Uma pessoa foi encontrada morta } \\
\text { no local, com um tiro no pescoço. }\end{array}$ & VIOLÊNCIA INDÍGENA & $\begin{array}{l}\text { Índios são violentos e causam a morte de outras pessoas; são selvagens, } \\
\text { inclinados a matar. }\end{array}$ \\
\hline $\begin{array}{l}\text { PF assume o caso. } \\
\text { CRIME GRAVÍSSIMO }\end{array}$ & $\begin{array}{l}\text { O envolvimento da PF sugere que o crime é de grande gravidade. Mas, na verdade, a } \\
\text { situação não poderia ser tratada por outra entidade segundo Constituição, uma vez que } \\
\text { é a PF quem deve cuidar dos índios; mas quem sabe disso? Além disso, "assumir o } \\
\text { caso" significa pressupor que houve um crime. }\end{array}$ \\
\hline $\begin{array}{l}\text { (...) vivem em uma mata; uma pessoa } \\
\text { foi encontrada morta; um homem } \\
\text { morre }\end{array}$ & $\begin{array}{l}\text { ÍNDIOS SÃO SELVAGENS } \\
\text { Índios não estão na mesmacategoria que os demais presentes notexto; são como bichos } \\
\text { que vivem na mata. }\end{array}$ \\
\hline
\end{tabular}




\section{B. Eixo analítico: Discurso e Ideologia (Notícia 1)}

\begin{tabular}{|c|c|c|}
\hline Construtos & Enunciados & Análise/síntese \\
\hline Escolhas lexicais & $\begin{array}{l}\text { 3. Invadem/invadiu/inva- } \\
\text { diram(3x)/invasão; } \\
\text { incendiaram/mataram } \\
\text { 4. Confessaram/em } \\
\text { depoimento } \quad \text { foram } \\
\text { ouvidos; } \\
\text { 5. Pistoleiros com os índios. }\end{array}$ & $\begin{array}{l}\text { 1. A escolha pela palavra "índios" e "indígenas" massifica e aciona a ideia } \\
\text { estereotipada de índios como uma unidade homogênea, sem diversidade; } \\
\text { também favorece o acionamento de uma visão negativa, do estereótipo de } \\
\text { selvagem; } \\
\text { 2. Ao usar a palavra "homem" logo após "índios", a manchete acaba por } \\
\text { estabelecer uma oposição entre "índios" e "homem", como se índios não } \\
\text { fizessem parte da mesma categoria que os seres humanos; mantém-se assim a } \\
\text { oposição estereotipada civizilizado X selvagem; } \\
\text { 3. "invadir" foi usado seis vezes no texto (cinco como verbo e uma como } \\
\text { substantivo); esse verbo implica violência, tomada de posse usando a força; } \\
\text { nesse mesmo sentido da violência, apareceram as palavras "incendiar" e } \\
\text { "matar" também associadas aos povo indígena Tupinambá; } \\
\text { 4. A escolha das palavras "confessar" e "depoimento" fazem dos Tupinambás réus } \\
\text { na história contada na notícia; enquanto os fazendeiros "foram ouvidos" pela } \\
\text { polícia, o que faz parecer que foram apenas vítimas; mesmo se forem apenas } \\
\text { vítimas, em um processo de investigação, o termo que se deveria empregar seria } \\
\text { "depoimento"; mas esse termo, com sua carga semântica habitualmente } \\
\text { associada com "a fala do criminoso", só foi empregado para os Tupinambás; } \\
\text { 5. Finalmente, o uso do termo "pistoleiro" e sua associação imediata "com os } \\
\text { índios" termina por sacramentar o estereotipo de "índio selvagem e violento" } \\
\text { que a notícia constroi e piora ao deixar entrever que "índios" também se } \\
\text { associam com criminosos como "pistoleiros", formando uma quadrilha. }\end{array}$ \\
\hline Topoi & $\begin{array}{l}\text { 1. Indios invadem fazendas, } \\
\text { homem morre e PF assume } \\
\text { o caso; }\end{array}$ & $\begin{array}{l}\text { 1. O principal lugar-comum nesta notícia é a ideia de que índios são invasores, } \\
\text { selvagens; a manchete já aciona esse topoi ao associá-los com "invasão" e } \\
\text { "morte"; a gravidade dos crimes cometidos por eles fica estampada no fim da } \\
\text { manchete: PF assume o caso; esse é outro lugar-comum: a PF lida com casos } \\
\text { graves; não se sabe, entretanto, que a PF é obrigada a entrar em cena quando o } \\
\text { assunto é povos indígenas brasileiros, cuja responsabilidade direta de cuidado } \\
\text { e guarda é da PF. }\end{array}$ \\
\hline
\end{tabular}




\begin{tabular}{|c|c|c|}
\hline & $\begin{array}{l}\text { 2. (...) vivem em uma mata } \\
\text { (...) }\end{array}$ & $\begin{array}{l}\text { 2. Esse topoi também reforça a ideia de que os povos indígenas são selvagens, } \\
\text { uma vez que vivem em uma mata tal qual bichos. }\end{array}$ \\
\hline \multicolumn{3}{|c|}{ ( } \\
\hline Evidencialidade & $\begin{array}{l}\text { (...) de acordo com } \\
\text { informações da Polícia } \\
\text { Federal (PF);/ Segundo o } \\
\text { órgão;/ Ainda de acordo com } \\
\text { a PF;/ Segundo a polícia } \\
\text { (...)/Segundo o delegado da } \\
\text { Polícia Federal (...) }\end{array}$ & $\begin{array}{l}\text { A notícia alude a uma única fonte de informação: a Polícia Federal (PF); os índios } \\
\text { não foram ouvidos, os fazendeiros não foram ouvidos. A PF goza de credibilidade } \\
\text { no Brasil, e isso daria à notícia maior valor de verdade. A visão negativa que se } \\
\text { transmite/endossa nessa notícia ganha força mais ainda quando as evidências para } \\
\text { tal advêm de um órgão como a PF, representante respeitado da Justiça brasileira. }\end{array}$ \\
\hline Tópico & $\begin{array}{l}\text { Índios invadem fazendas, } \\
\text { homem morre e PF assume o } \\
\text { caso; }\end{array}$ & O tópico dessa notícia é “invasão e violência praticada por indígenas”. \\
\hline Contexto & $\begin{array}{l}\text { Índios invadem fazendas em } \\
\text { Itapebi }\end{array}$ & $\begin{array}{l}\text { Nos últimos anos, o contexto brasileiro (ou seja, seu cenário social, político, } \\
\text { financeiro e cultural) tem colocado os povos indígenas como entrave para o } \\
\text { desenvolvimento do país. A invasão de fazendas, como na notícia em análise, seria } \\
\text { um exemplo disso, uma vez que supostas terras produtivas (fazendas) estariam } \\
\text { sendo tomadas de assalto por selvagens que vivem na mata. Há inúmeros conflitos } \\
\text { sendo relatados na imprensa brasileira envolvendo povos indígenas, terras, } \\
\text { cobrança ilegal de pedágio, impedimento de construção de hidrelétricas que vão, } \\
\text { teoricamente, fazer o Brasil crescer. }\end{array}$ \\
\hline $\begin{array}{l}\text { Racismo do dia a } \\
\text { dia }\end{array}$ & $\begin{array}{l}\text { Índios invadem fazendas em } \\
\text { Itapebi; índígenas; }\end{array}$ & $\begin{array}{l}\text { A denominação "índios" e "indígenas" é um tipo de racismo do dia a dia. } \\
\text { Rotineiramente, escutamos esses termos, que criam a imagem do índio genérico, } \\
\text { homogêneo como parte de uma categoria negativa, que se opõe ao "homem", ao } \\
\text { civilizado. Passa-se a ideia de que é comum que haja invasões e violência grave } \\
\text { (assassinatos) praticadas por povos indígenas; por isso, seriam uma ameaça ao } \\
\text { bem-estar da sociedade. }\end{array}$ \\
\hline $\begin{array}{l}\text { Implicações/ } \\
\text { Pressuposiçōes }\end{array}$ & 1. (...) um homem morre (...); & $\begin{array}{l}\text { 1. O enunciado "um homem morre" ocorre justamente após o enunciado "índios } \\
\text { invadem fazendas", levando ao estabelecimento de uma relação de causa e } \\
\text { consequência entre eles; fica implícito que os índios ou a invasão organizada } \\
\text { por eles foi a responsável pela morte; o enunciado seguinte, "PF assume o }\end{array}$ \\
\hline
\end{tabular}




\begin{tabular}{|c|c|c|}
\hline & $\begin{array}{l}\text { 2. Uma pessoa foi } \\
\text { encontrada morta no local, } \\
\text { com um tiro no pescoço. }\end{array}$ & $\begin{array}{l}\text { caso", conduz igualmente ao implícito: "houve crime grave", "os índios } \\
\text { invadiram fazendas e mataram uma pessoa"; } \\
\text { 2. A voz passiva implica, semanticamente, a atuação de um agente sobre um } \\
\text { paciente; logo, embora não haja um agente explícito nesse enunciado 2, ele é } \\
\text { pressuposto pela voz verbal; no caso, fica implícito mais uma vez que os índios } \\
\text { é que foram o agente dessa morte; a morte foi bastante violenta: um tiro no } \\
\text { pescoço; e aí fica implícito que índios são violentos e usam armas. }\end{array}$ \\
\hline $\begin{array}{l}\text { Sinônimos/ } \\
\text { Paráfrases }\end{array}$ & $\begin{array}{l}\text { 1. Índios, indígenas, grupo } \\
\text { de indígenas, tribo } \\
\text { Tupinambá }\end{array}$ & $\begin{array}{l}\text { 1. Em lugar de falar em primeiro plano de "índios Tupinambás", o jornal optou } \\
\text { por se referir a eles quase exclusivamente por palavras próximas, mas que não } \\
\text { têm o mesmo valor; os termos "índios" e "indígenas" massificam, } \\
\text { homogeneizam a diversidade de povos indígenas brasileiros; o termo "grupo de } \\
\text { indígenas" faz pensar em associação entre indivíduos para determinado fim, } \\
\text { igualmente comprometendo negativamente a identidade indígena; e, por fim, o } \\
\text { termo "tribo" é igualmente carregado de valor negativo e usado como sinônimo } \\
\text { de "povo". } \\
\text { 2. O uso de "propriedade" como sinônimo de "fazenda" acaba por cumprir o papel } \\
\text { de ressaltar que o que estava sendo notíciado era a usurpação de uma proriedade } \\
\text { privada; fica pressuposto aí que existem dois lados: os proprietários } \\
\text { (fazendeiros) e os invasores; fica implícito que os índios é que são os } \\
\text { criminosos; a notícia não apurou se os motivos alegados pelos Tupinambás para } \\
\text { ocuparem a fazenda era ou não letígimo: recuperar as terras que outrora lhes } \\
\text { pertenciam e que haviam sido invadidas por não-indígenas; essa não apuração } \\
\text { acaba por implicar uma identidade criminosa para os Tupinambás. }\end{array}$ \\
\hline Disclaimers & a notícia como um todo & $\begin{array}{l}\text { A notícia como um todo é um exemplo de disclaimer, especificamente do tipo } \\
\text { Inversão, culpando a vítima (cf. seção } 2.2 .7 \text { ): os povos indígenas eram, } \\
\text { historicamente, os donos das terras brasílicas, sendo os não-indígenas aqui } \\
\text { chegados com Cabral a partir de } 1500 \text { os usurpadores de suas terras e riquezas; a } \\
\text { notícia, porém, inverte esses papéis, transformando algozes em vítimas, e vítimas } \\
\text { em algozes. }\end{array}$ \\
\hline
\end{tabular}




\begin{tabular}{|c|c|c|}
\hline Coerência local & $\begin{array}{l}\text { Índios invadem fazenda } \Rightarrow \\
\text { homem morre } \Rightarrow \text { indigenas } \\
\text { estão lutando } \Rightarrow \text { incendiaram } \\
\text { uma das casas da sede } \Rightarrow \text { uma } \\
\text { pessoa foi encontrada morta } \\
\text { no local } \Rightarrow \text { os indigenas } \\
\text { confessaram } \Rightarrow \text { o suspeito do } \\
\text { crime ainda na foi } \\
\text { identificado } \Rightarrow \quad \text { em } \\
\text { depoimento } \Rightarrow \text { vivem em uma } \\
\text { mata } \Rightarrow \text { estão lutando } \Rightarrow \text { os } \\
\text { indios invadiram } \Rightarrow e \\
\text { mataram animais } \Rightarrow \quad \Rightarrow \\
\text { pistoleiros estariam } \\
\text { envolvidos com os indios }\end{array}$ & $\begin{array}{l}\text { O texto da notícia apresenta coerência local centrada na ideia de que os índios são } \\
\text { violentos e criminosos. Do início ao fim do texto, a notícia mantém firme a lógica } \\
\text { dos fatos segundo essa ótica, deixando de dar o mesmo destaque a outras possíveis. }\end{array}$ \\
\hline Contraste & $\begin{array}{l}\text { Índios/indigenas/tribo/ } \\
\text { grupo/ uma mata } \\
\text { X homem/pessoa/fazendeiros } \\
\text { /fazenda/propriedade }\end{array}$ & $\begin{array}{l}\text { Na notícia, fica nítida polarização entre "nós" e "eles", marcando o grupo de } \\
\text { dominantes de um lado e dominados de outro; os dominantes são categorizados } \\
\text { como "homem", "pessoa", "fazendeiro"; os dominados são "índios", "indígenas", } \\
\text { "tribo", "grupo"; enquanto aqueles são caracterizados como pertencentes a um } \\
\text { locus como "fazenda" e "propriedade, estes são alocados em "uma mata". O } \\
\text { contraste marca traços ideológicos bastante difundidos em nossa sociedade sobre } \\
\text { o que são os povos indígenas e que espaço ocupam em nosso território. }\end{array}$ \\
\hline $\begin{array}{l}\text { Exemplos/ } \\
\text { Ilustrações }\end{array}$ & $\begin{array}{l}\text { I. Índios acusados de } \\
\text { assassinatos vão responder } \\
\text { processo em liberdade } \\
\text { 2. Índios fazem protesto na } \\
\text { BA-001 e interditam os dois } \\
\text { sentidos da via }\end{array}$ & $\begin{array}{l}\text { Na notícia analisada, encontramos alguns hiperlinks sob o título de "saiba mais". } \\
1,2 \text { e } 3 \text { são as manchetes (e chamadas) e, como podemos observar, todas remetem } \\
\text { a conflitos e violência envolvendo indígenas. Apenas a última manchete não traz a } \\
\text { figura de um indígena violento, mas, assim como as demais, massifica as } \\
\text { comunidades indígenas por não trazer a etnia. Além disso, é a única que está na } \\
\text { voz passiva, sem o espaço do agente preenchido. Nenhum dos hiperlinks presentes } \\
\text { contribui de forma positiva para a construção de uma representação indígena. }\end{array}$ \\
\hline
\end{tabular}




\begin{tabular}{|c|c|c|}
\hline & $\begin{array}{l}\text { 3. Índio é encontrado morto } \\
\text { em Santa Cruz Cabrália, no } \\
\text { sul da Bahia }\end{array}$ & \\
\hline Vaguidade & $\begin{array}{l}\text { 1. Índios X grupo de } 20 \\
\text { indígenas } \\
\text { 2. Fazendas X fazenda X três } \\
\text { fazendas X a fazenda X ao } \\
\text { redor da fazenda X } \\
\text { fazendeiros X propriedade } \\
\text { X da fazenda X no local } \\
\text { 3. Homem morre; pessoa foi } \\
\text { encontrada morta no local }\end{array}$ & $\begin{array}{l}\text { 1. A notícia não é, preponderantemente, clara quanto ao números de Tupinambás } \\
\text { envolvidos na situação; em apenas uma ocasião, ela faz menção ao número } 20 \\
\text { (lead); mas, na manchete e no restante do texto, usa o plural "índios" ou } \\
\text { "indígenas"; essa vagueza não só cria uma leitura homogênea dos povos } \\
\text { indígenas brasileiros como já dito, mas também induz o leitor a pensar em uma } \\
\text { grande quantidade de índios; } \\
\text { 2. A manchete fala em "fazendas", dando a entender que foram várias; mas no } \\
\text { lead se fala apenas em "fazenda", no singular, dando a entender que foi apenas } \\
\text { uma; logo depois, se fala em "três fazendas" para, no restante do texto, voltar- } \\
\text { se a usar referêcias no singular: "a fazenda", "ao redor da fazenda", } \\
\text { "propriedade", "da fazenda", "no local"; em meio a esses usos no singular, } \\
\text { aparece a referência a "fazendeiros", assim no plural, dando novamente a } \\
\text { entender que era mais de uma fazenda. Uma leitura rápida e desatenta pode } \\
\text { levar o leitor a pensar que vários índios invadiram várias fazendas justamente } \\
\text { pela falta de precisão com que as informações são dadas; logo, essa falta de } \\
\text { precisão pode induzir a leituras equivocadas dos fatos, em que os Tupinambás } \\
\text { são fortemente colocados na posição de criminosos; } \\
\text { 3. Quem é a pessoa que morreu, ou melhor, que foi morta com um tiro no pescoço? } \\
\text { O jornal não apurou essa informação ou não quis revelá-la. Seria ele um jagunço } \\
\text { da fazenda? Com certeza, não era um índio ou um fazendeiro ou filho do } \\
\text { fazendeiro, pois isso seria por si só parte indispensável do "furo"; essa falta de } \\
\text { clareza quanto à identidade do homem assassinado induz a pensar nele como } \\
\text { vítima apenas (talvez um trabalhador da fazenda), deixando os índios - os } \\
\text { agentes da invasão - na posição de agentes desse assassinato, uma posição } \\
\text { naturalizada pela estruturação textual ao invés de ser colocada realmente em } \\
\text { aberto como deveria ser. Também não foi dito no texto se houve algum índio } \\
\text { ferido no confronto entre eles e os fazendeiros. A quem interessa esse tipo de } \\
\text { omissão? }\end{array}$ \\
\hline
\end{tabular}




\begin{tabular}{|c|c|c|}
\hline Modelos mentais & & $\begin{array}{l}\text { Como apresentado em A5 acima, os frames acionados pela notícia fazem com que } \\
\text { os modelos mentais que se confirmam na leitura dessa notícia sejam os de } \\
\text { indígenas violentos, que invadem propriedades privadas e matam pessoas. Torna- } \\
\text { se impossível separar os indígenas de episódios violentos. Com isso, reforça-se o } \\
\text { senso comum e o topoi de que, sempre que houver conflito envolvendo os } \\
\text { indígenas, alguém sairá morto e eles serão violentos. }\end{array}$ \\
\hline $\begin{array}{l}\text { Modelo de } \\
\text { dominação de } \\
\text { Thompson }\end{array}$ & $\begin{array}{l}\text { 1. Índios; indígenas; } \\
\text { 2. Enunciados usados na } \\
\text { reificação: } \\
\text { 2.1. e 2.2: Indios invadem } \\
\text { fazendas, homem morre } \\
\text { (...); (...) vivem em uma } \\
\text { mata ao redor da fazenda } \\
\text { (...) } \\
\text { 1.3.(..) os fazendeiros } \\
\text { responderam a invasão } \\
\text { com violência; }\end{array}$ & $\begin{array}{l}\text { 1. Unificação: Os índios/indígenas são uma única comunidade que nos ameaça. } \\
\text { 2. Reificação: na notícia } 1 \text { em análise, encontramos as quatro estratégias usadas } \\
\text { para a reificação, que ocorre quando uma situação transitória é apresentada } \\
\text { como se fosse "permanente, natural, atemporal”, a saber: } \\
\text { 2.1. Naturalização: os acontecimentos na notícia são dados como naturais, } \\
\text { corriqueiros; a escolha dos tempos verbais pode ser uma evidência a favor } \\
\text { dessa análise; } \\
\text { 2.2. Eternalização: a começar pelo título, a notícia dá a entender que índios } \\
\text { são eternos invasores de fazendas ("invadem" e não "invadiram") e } \\
\text { assassinos de gente ("homem morre"); isso é assim apresentado, mesmo a } \\
\text { ocupação da fazenda já ter chegado ao fim, fato que só é revelado no meio } \\
\text { da notícia, com pouquíssimo destaque; } \\
\text { 2.3. Nominalização: os Tupinambás são substituídos por "invasão", forma } \\
\text { nominalizada do verbo "invadir" (o qual ocorreu cinco vezes na notícia); } \\
\text { essa forma nominalizada foi usada justamente quando se noticiou a ação } \\
\text { dos fazendeiros contra eles: “(...) os fazendeiros responderam a invasão } \\
\text { com violência". Nesse momento em que os Tupinambás seriam vítimas, } \\
\text { eles foram transformados em nome, sendo, de certa forma, apagados. } \\
\text { 2.4.Passivização: há quatro usos de voz passiva na notícia; a passiva coloca } \\
\text { um paciente na função de sujeito, passando-o à posição de tópico; o agente, } \\
\text { por sua vez, passa a ocupar função de adjunto, podendo inclusive ser } \\
\text { omitido (essa omissão é o que se dá nos três primeiros exemplos de passiva } \\
\text { ao lado identificados). Essa é uma estratégia discursiva. Apesar de o agente } \\
\text { ter sido omitido nos exemplos identificados, ele é facilmente recuperado }\end{array}$ \\
\hline
\end{tabular}




\begin{tabular}{|l|l|l|}
\hline & & $\begin{array}{l}\text { pelo contexto. A interpretação mais plausível, pelo contexto, é a de que } \\
\text { uma pessoa foi morta por índios. Assim, a passivização foi uma estratégia } \\
\text { não para retirar a importância do agente, nesse caso, mas sim para acusá-lo } \\
\text { de maneira implícita. }\end{array}$ \\
\hline
\end{tabular}

\section{Eixo analítico: Comunicação (Notícia 1)}

\section{C.1. Qual(is) o(s) critério(s) de noticiabilidade ressaltado(s)? (Notícia 1)}

\begin{tabular}{|c|c|c|}
\hline $\begin{array}{l}\text { Critérios } \\
\text { de noticiabilidade }\end{array}$ & Enunciados & Análise/síntese \\
\hline \multicolumn{3}{|l|}{ Raridade } \\
\hline Interesse nacional & Índios invadem fazendas & $\begin{array}{l}\text { Fazendas estão sendo invadidas por índios, a propriedade privada está sendo } \\
\text { usurpada; uma fonte importante de alimentos está em risco. }\end{array}$ \\
\hline $\begin{array}{l}\text { Interesse } \\
\text { pessoal/econômico }\end{array}$ & $\begin{array}{l}\text { Os indios invadiram a propriedade } e \\
\text { mataram animais da fazenda. }\end{array}$ & Os índios estão prejudicando o agroempreendedor. \\
\hline \multicolumn{3}{|l|}{ Catástrofe } \\
\hline $\begin{array}{l}\text { Interesse } \\
\text { universal }\end{array}$ & Um homem morre & $\begin{array}{l}\text { A preservação da vida ganha destaque na manchete justamente ao falar da morte } \\
\text { de uma pessoa. }\end{array}$ \\
\hline Injustiça & Índios invadem fazendas em Itapebi & Invasão e perda da propriedade privada. \\
\hline Crime/violência & $\begin{array}{l}\text { Uma pessoa foi encontrada morta } \\
\text { no local, com um tiro no pescoço. } \\
\text { (...) pistoleiros estariam } \\
\text { envolvidos com índios }\end{array}$ & $\begin{array}{l}\text { Além da invasão ser um crime, o assassinato de uma pessoa também é. Tão grave } \\
\text { quanto, ainda seria suposta associação entre pistoleiros e índios, em formação de } \\
\text { quadrilha. }\end{array}$ \\
\hline \multicolumn{3}{|l|}{ Drama } \\
\hline $\begin{array}{ll}\text { Proeminência } & \text { do } \\
\text { indivíduo } & \text { na } \\
\text { sociedade } & \end{array}$ & $\begin{array}{l}\text { Índios, Polícia } \quad \text { Federal } e \\
\text { fazendeiros }\end{array}$ & $\begin{array}{l}\text { A referência a "índios" chama a atenção de leitores, dadas, sobretudo, as visões } \\
\text { estereotipadas e negativas sobre eles; a polícia federal goza de prestígio social e } \\
\text { nacional; e fazendeiros são associados à produção agrícola, considerada }\end{array}$ \\
\hline
\end{tabular}




\begin{tabular}{|l|l|l|}
\hline & & $\begin{array}{l}\text { necessária ao funcionamento do país; logo, também eles têm proeminência } \\
\text { suficiente para ser notícia. }\end{array}$ \\
\hline
\end{tabular}

\section{C.2. Estrutura da notícia (Notícia 1)}

\begin{tabular}{|c|c|c|}
\hline $\begin{array}{l}\text { Estrutura } \\
\text { da notícia }\end{array}$ & Enunciados & Análise/síntese \\
\hline Manchete & $\begin{array}{l}\text { Indios invadem fazendas em Itapebi, um } \\
\text { homem morre e PF assume caso }\end{array}$ & $\begin{array}{l}\text { Há uma sucessão de fatos. Primeiro, os índios invadem; em seguida, alguém } \\
\text { morre, provavelmente por consequência dessa invasão. PF é obrigada a assumir } \\
\text { o caso, pois provavelmente foi algo grave. Aqui, não se cita a etnia, o número de } \\
\text { indígenas envolvidos no processo, seus motivos ou quando ocorreu o caso. }\end{array}$ \\
\hline Lead & $\begin{array}{l}\text { Grupo de } 20 \text { indígenas invadiu } \\
\text { fazenda no domingo, no interior da } \\
\text { Bahia. Indigenas afirmam que } \\
\text { estão lutando pela recuperação de } \\
\text { suas terras. }\end{array}$ & $\begin{array}{l}\text { Aqui sim, temos uma noção de quantidade de indígenas envolvidos no processo. } \\
\text { Há também, de maneira deturpada, a justificativa pela invasão. }\end{array}$ \\
\hline $\begin{array}{l}\text { Informações } \\
\text { primárias/iniciais }\end{array}$ & & $\begin{array}{l}\text { Há uma invasão ocorrendo na Bahia. Muitos indígenas estão atacando fazendas. } \\
\text { Alguém morreu, e a PF teve de assumir o caso. }\end{array}$ \\
\hline $\begin{array}{l}\text { Informações } \\
\text { secundárias/finais }\end{array}$ & & $\begin{array}{l}\text { Cerca de } 20 \text { (não sabemos o número exato) indígenas invadiu } 3 \text { fazendas no } \\
\text { interior da Bahia. Os indígenas confessaram ter invadido a fazenda e incendiado } \\
\text { a casa, mas negam o homicídio. Eles já deixaram a fazenda. }\end{array}$ \\
\hline $\begin{array}{l}\text { Caderno/ } \\
\text { Local } \\
\text { da publicação }\end{array}$ & $\begin{array}{l}\text { Caderno local/ } \\
\text { Bahia }\end{array}$ & $\begin{array}{l}\text { A opção pela publicação no caderno local provavelmente quer dizer que a notícia } \\
\text { não é de interesse nacional. }\end{array}$ \\
\hline
\end{tabular}




\subsubsection{Síntese da análise textual da notícia 1}

Notamos que há, preferencialmente, uso da voz ativa. Os indígenas são colocados normalmente na posição de sujeito e agem sobre objetos inanimados e, normalmente são evocados por verbos que exigem um sujeito com alto grau de controle e volição. Semanticamente, esses verbos são negativos. O papel semântico do indígena é normalmente o de agente.

Infelizmente, quando os indígenas não aparecem na posição de sujeito, a voz ativa é usada para provocar no leitor a inferência de que, mesmo assim, eles ocupam o papel semântico de agentes, como por exemplo no enunciado "homem morre". Aparentemente, nesse enunciando, homem seria tema, mas a sequência dos fatos apresentados nos levam a crer que, na verdade, o homem foi morto, e o agente é indígena. Só é possível fazermos essas inferências porque algumas pistas nos são apresentadas antes. Elas delineiam os caminhos que seguiremos para preencher os espações vazios (TRAUGOTT \& DASHER, 2005).

Percebemos que os frames acionados, as metáforas e metonímias evocam uma verdadeira GUERRA (LAKOFF \& JOHNSON, 1980) Há tiros, mortos, violência, uma invasão e a polícia federal. O motivo para tanto só se apresenta no fim do texto, mesmo assim, atrelado à informação de que os indígenas "vivem na mata ao redor" como se fossem animais.

A iconicidade também revela muito sobre a ideologia presente no texto. Estruturas maiores são utilizadas quando se fala dos indígenas, trazendo a perspectiva de um grupo enorme, enquanto estruturas menores são utilizadas para se referir aos não-índios.

A manchete traz uma sucessão de fatos para que o leitor faça a inferência de que estão todos relacionados. O agente de uma ação é provavelmente agente de todas as outras. Há , logo na manchete, uma generalização dos indígenas, massificando-os ou, como postulado por Thompson (1994), unificando-os para que todos sejam vistos como um grupo perigoso, alimentando o que van Dijk (2003) chama de racismo do dia a dia. Como a estrutura da notícia é uma pirâmide invertida (BONINI, 2002), há no topo a informação de que eram muitos indígenas; depois um grupo de 20; no fim da notícia, o número já não chega a 20, mas o que permanece no imaginário do leitor é a primeira informação, e ela é que vai nortear todas as interpretações que virão a seguir durante a leitura da notícia.

Van Dijk (2003, p. 51) nos alerta para a importância de analisarmos quais os atores de um texto. Os grupos minoritários, segundo o autor, podem não somente ser generalizados como também colocados em um papel de agentes propositalmente, como ocorre na notícia 1 acima. 
Da mesma forma, o uso da voz passiva coloca o paciente em destaque, tornando-o sujeito e retirando a importância do agente. Nessa notícia, temos quatro exemplos de voz passiva que retiram de cena os responsáveis por crimes ou por fiscalizá-los. Para van Dijk (2003), isso faz parte de uma estratégia básica de dominação: não dizer coisas negativas a nosso respeito.

Tanto van Dijk (2003) quanto Thompson (2010) afirmam que a estratégia de massificar e atribuir características negativas a um grupo tornam o processo de dominação mais viável. Cria-se um inimigo em comum que se opõe ao nosso grupo e, por isso, devemos nos unir para combatê-lo.

Além disso, essa notícia se utiliza muito do que van Dijk (2003) denomina de implicações e pressuposições. Ela nos leva a crer que os indígenas são os responsáveis pela morte do homem, criando uma coerência local e global para as estruturas eleitas: índios sempre agentes de verbos semanticamente negativos.

No campo cognitivo, o texto como um todo evoca o conceito de GUERRA: pessoas armadas, tiros, mortes, polícia e interrogatório. Além disso, as escolhas lexicais para se referir aos indígenas como vivem na mata ao redor os reduz à condição de animais. Percebemos a diferença no tratamento dispensado ao grupo indígena até mesmo no tamanho das estruturas eleitas. Elas nos induzem a pensar em um grupo enorme, numericamente superior ao grupo dos não indígenas.

No campo da comunicação, desde a manchete até a organização das informações em primárias e secundárias nos mostram que é mais relevante destacar a morte e a agressividade indígena do que suas motivações.

A notícia como um todo é extremamente prejudicial à construção de uma representação indígena. Dificilmente, o leitor, após terminar a leitura do texto, construirá uma imagem positiva dos índios Tupinambá ou questionará as ações dos fazendeiros. 


\subsection{Análise Textual 2 - Notícia 2}

\section{Notícia 2}

\section{Contra invasor, justiça com as próprias mãos}

Membros da etnia Kaapor atacam e expulsam madeireiros ilegais de reserva no Noroeste do Maranhão CENTRO DO GUILHERME, MA

Uma ação liderada por membros da etnia Kaapor no último dia 7 de agosto contra madeireiros ilegais que atuam dentro da Terra Indígena Alto Turiaçu, nas imediações de Centro do Guilherme, no Noroeste do Maranhão, lançou nova luz sobre as permanentes tensões nas reservas da Amazônia Legal na região. Imagens divulgadas ontem pela agência de noticias Reuters mostram uma blitz levada a cabo por Kaapors, com apoio de outras quatro tribos e sem a participação de forças do Estado, para prender os invasores. Alguns dos madeireiros foram espancados e amarrados, e outros, deixados nus para supostamente serem entregues a agentes policiais.

CAMINHÕES E ACAMPAMENTOS

De acordo com o fotógrafo Lunaé Parracho, que registrou a operação dos índios para a agência inglesa, os membros da tribo dizem estar cansados de pedir ajuda às autoridades e à Fundação Nacional do Índio (Funai). Eles vêm denunciando a constante presença de madeireiros, que dispõem de caminhões e tratores e montam verdadeiros acampamentos livremente para explorar as riquezas vegetais da reserva. Entre as fotografias, há cenas de supostos madeireiros amarrados e cercados por homens armados de paus, foices e até rifles. Um deles tenta fugir e é açoitado por um homem que seria indígena.

As roupas de alguns deles teriam sido tiradas para impedir que fugissem. A Terra Indígena Alto Turiaçu se estende por uma área de 5.305 quilometros quadrados, o que equivale a mais de quatro vezes a cidade do Rio de Janeiro. Como todas as reservas de grande extensão, é de difícil monitoramento e acaba sendo alvo fácil de traficantes de madeira. A estrutura dos invasores fica clara pelas imagens de caminhões queimados pelos indigenas durante a ação de agosto. A Funai informou que os nativos, chamados de "guardiões da floresta", têm realizado naquela região ações de apreensão de madeireiros ilegais. Em nota ao site de notícias G1, o órgão federal disse ainda que "tem conhecimento dessas ações e já solicitou apoio policial para evitar que ocorram excessos ou conflitos". As imagens de ontem correram o mundo e foram publicadas em portais de noticias internacionais.

(Fonte: $O$ Globo, 05 de setembro de 2014.

<http://clipping.radiobras.gov.br/clipping/novo/Construtor.php?Imprimir=1\&ano ant=2014\&Opcao=Materia\&veiculo=5\&ID=1970162\&txt=\% 20indios\%20indigenas\%20tribo > acesso em julho de 2015.) 


\section{A - Eixo analítico: Linguística Cognitivo-Funcional (Linguística Centrada no Uso) (Notícia 2)}

\section{A.1 Voz (stricto sensu e lato sensu)/ Valência verbal (Notícia 2)}

\begin{tabular}{|c|c|c|c|c|}
\hline Enunciados & Voz /ordem & $\begin{array}{l}\text { Valência } \\
\text { Sintática }\end{array}$ & $\begin{array}{l}\text { Valência } \\
\text { Semântica }\end{array}$ & Análise/Síntese \\
\hline $\begin{array}{l}\text { Contra invasor, justiça com } \\
\text { as próprias mãos }\end{array}$ & $\begin{array}{lr}\text { Não há uma voz } \\
\text { explícita } & \text { na } \\
\text { oração. Pode-se } \\
\text { entender romo } \\
\text { uma voz ativa } \\
\begin{array}{lr}\text { acionada } & \text { no } \\
\text { inconsciente } & \text { do } \\
\text { leitor }\end{array}\end{array}$ & \begin{tabular}{c|}
0 \\
(não há \\
relações \\
gramaticais \\
aí por falta \\
de um \\
verbo)
\end{tabular} & $\begin{array}{c}2 \\
\text { (semantica } \\
\text { mente, } \\
\text { alguém } \\
\text { praticou } \\
\text { justiça } \\
\text { contra } \\
\text { outro) }\end{array}$ & $\begin{array}{l}\text { Não há um verbo na oração. Não é uma construção } \\
\text { prototípica. Em pesquisa que fizemos em } 13 / 12 / 2015 \text {, na aba } \\
\text { "notícias" no google, encontramos a expressão "Justiça com } \\
\text { as próprias mãos" em construções passivas uma única vez, } \\
\text { enquanto na voz ativa ocorreu } 1230 \text { vezes. Assim, assumo } \\
\text { que aqui a intenção é de uma interpretação ativa. Após ler o } \\
\text { texto, fica claro que os índios ka'apor seriam o sujeito ativo. }\end{array}$ \\
\hline $\begin{array}{l}\text { 1. Membros da etnia Kaapor } \\
\text { atacam [madeireiros } \\
\text { ilegais] }\end{array}$ & $\begin{array}{ll}\text { 1. Voz } & \text { ativa; } \\
\text { ordem } & \text { direta } \\
(\mathrm{SVO}) & \end{array}$ & 2 & 2 & $\begin{array}{l}\text { Interessante notar que se coordenam duas orações com } \\
\text { verbos semanticamente negativos com seus argumentos } \\
\text { devidamente preenchidos. }\end{array}$ \\
\hline $\begin{array}{l}\text { 2. e expulsam madeireiros } \\
\text { ilegais de reserva no } \\
\text { Noroeste do Maranhão }\end{array}$ & $\begin{array}{l}\text { 2. Voz ativa; } \\
\text { ordem direta } \\
\text { (SVO); }\end{array}$ & 3 & 3 & \\
\hline $\begin{array}{l}\text { 1. Uma ação liderada por } \\
\text { membros da etnia Kaapor } \\
\text { no último dia } 7 \text { de agosto } \\
\text { contra madeireiros ilegais } \\
\text { 2.[que atuam dentro da } \\
\text { Terra Indígena Alto } \\
\text { Turiaçu, nas imediações } \\
\text { de Centro do Guilherme, } \\
\text { no Noroeste do } \\
\text { Maranhão,] lançou nova } \\
\text { luz sobre as permanentes } \\
\text { tensões nas reservas da }\end{array}$ & $\begin{array}{ll}\text { 1. Voz ativa; } \\
\text { ordem direta } \\
\text { (SVO); }\end{array}$ & 2 & 2 & $\begin{array}{l}\text { Utiliza-se um verbo com um sujeito não prototípico: não é } \\
\text { humano, não tem volição nem controle. Chama a atenção } \\
\text { também a extensão do sujeito, que torna difícil sua } \\
\text { identificação. }\end{array}$ \\
\hline
\end{tabular}




\begin{tabular}{|c|c|c|c|c|}
\hline $\begin{array}{l}\text { Amazônia Legal na } \\
\text { região. }\end{array}$ & & & & \\
\hline $\begin{array}{l}\text { 1.[Alguns dos madeireiros } \\
\text { foram espancados] 2.[e } \\
\text { amarrados],3.[e outros, } \\
\text { deixados nus] 4.[para } \\
\text { supostamente } \\
\text { entregues a } \\
\text { policiais]. }\end{array}$ & $\begin{array}{l}\text { Voz passiva }(\mathrm{SV}) \\
\text { ordem direta; }\end{array}$ & 1 & 2 & $\begin{array}{l}\text { Há uma sucessão de usos da voz passiva. Os madeireiros se } \\
\text { tornam sujeito de uma passiva, ou seja, são sujeitos não- } \\
\text { agentes. São sujeitos pacientes de } 4 \text { verbos. Apesar de não } \\
\text { haver o agente da passiva explicitado, ele é previsto: os } \\
\text { índios kaapor. }\end{array}$ \\
\hline
\end{tabular}

\section{A.2. Relações gramaticais/ Papéis Semânticos/ Papéis Pragmáticos (Notícia 2)}

\begin{tabular}{|c|c|c|c|c|c|}
\hline Enunciados & $\begin{array}{l}\text { Argumentos/ } \\
\text { Adjuntos }\end{array}$ & $\begin{array}{c}\text { RG ou } \\
\text { Adjuntos }\end{array}$ & $\begin{array}{c}\text { Papel } \\
\text { Semântico }\end{array}$ & $\begin{array}{c}\text { Papel } \\
\text { Pragmático }\end{array}$ & Análise/Síntese \\
\hline $\begin{array}{l}\text { 1. Membros da etnia } \\
\text { Kaapor atacam } \\
\text { [madeireiros ilegais] }\end{array}$ & $\begin{array}{l}\quad \text { Oração } 1 \\
\text { Arg1:Membros } \\
\text { da etnia } \\
\text { Kaapor } \\
\text { Arg2: } \\
\text { madeireiros } \\
\text { ilegais }\end{array}$ & $\begin{array}{l}\text { Oração } 1 \\
\text { Arg1: Sujeito } \\
\text { Arg2: Objeto } \\
\text { direto }\end{array}$ & $\begin{array}{l}\text { Oração 1 } \\
\text { Arg1: Agente } \\
\text { Arg2: Paciente }\end{array}$ & $\begin{array}{l}\text { Oração } 1 \\
\text { Arg1: Tópico } \\
\text { Arg2: Foco }\end{array}$ & $\begin{array}{l}\text { Um alinhamento prototípico. Sujeito } \\
\text { humano, com volição, agente. O sujeito, } \\
\text { porém, controla dois verbos com semântica } \\
\text { negativa. Apesar de "ilegais", os } \\
\text { madeireiros são tratados como pacientes em } \\
\text { ambos os casos. É como se fossem apenas } \\
\text { vítimas, nada tendo feito de errado. }\end{array}$ \\
\hline
\end{tabular}




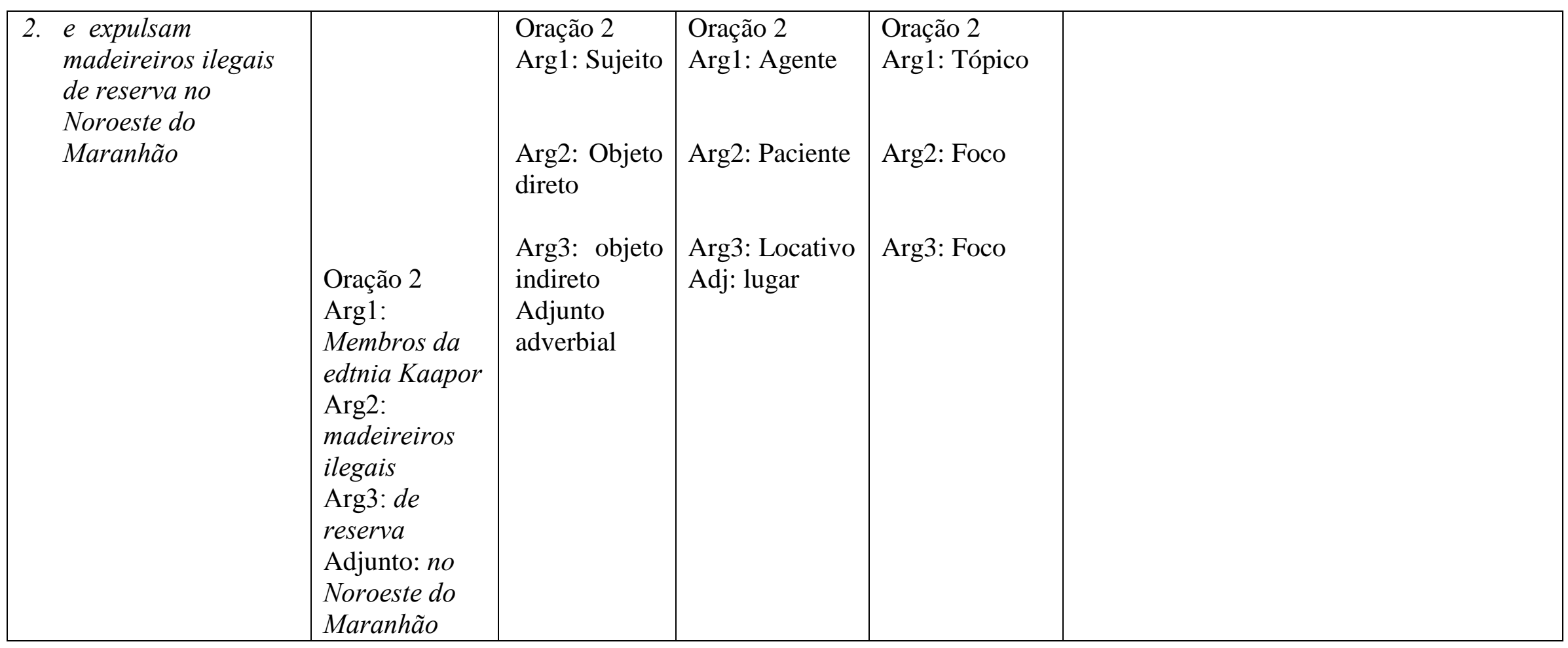




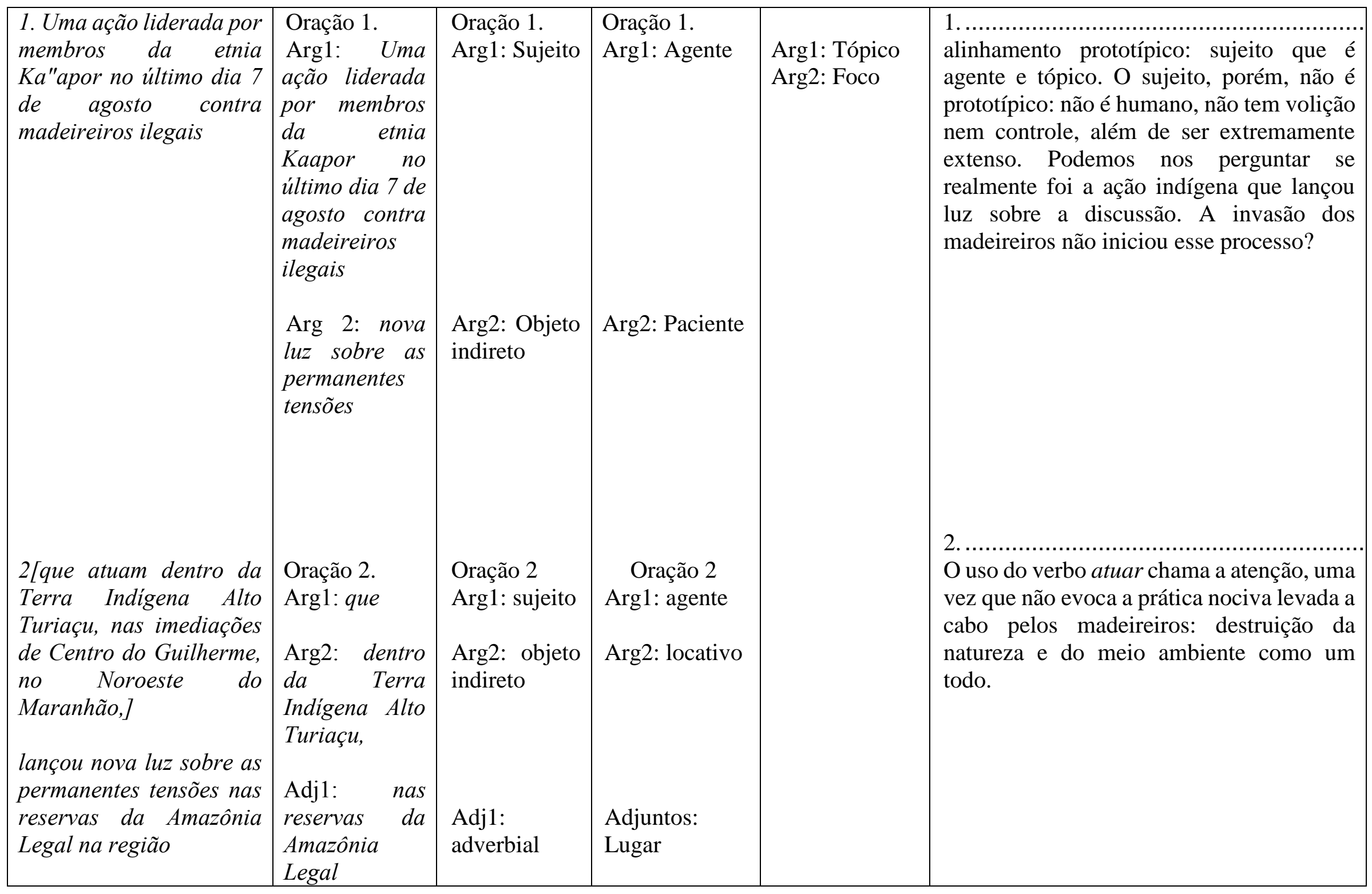




\begin{tabular}{|c|c|c|c|c|c|}
\hline & $\begin{array}{l}\text { Adj2: } \quad n a \\
\text { região }\end{array}$ & $\begin{array}{l}\text { Adj2: } \\
\text { adverbial }\end{array}$ & & & \\
\hline $\begin{array}{l}\text { 1.[Alguns dos } \\
\text { madeireiros foram } \\
\text { espancados] 2.[e } \\
\text { amarrados],3.[ e outros, } \\
\text { deixados nus] 4.[para } \\
\text { supostamenter serem } \\
\text { entregues a agentes } \\
\text { policiais]. }\end{array}$ & $\begin{array}{l}\text { Argl: alguns } \\
\text { dos } \\
\text { madeireiros } \\
\text { Adj: a agentes } \\
\text { policiais }\end{array}$ & $\begin{array}{l}\text { Arg1: Sujeito } \\
\text { Adj: adjunto } \\
\text { adverbial }\end{array}$ & $\begin{array}{l}\text { Arg 1: } \\
\text { Paciente } \\
\text { Adj: } \\
\text { Destinatário }\end{array}$ & Arg 1: Tópico & $\begin{array}{l}\text { Há um alinhamento prototípico para a voz } \\
\text { passiva. O sujeito é paciente, sofre mudança } \\
\text { de estado. O quadro mental que se forma é } \\
\text { estático. Não enxergamos a ação, mas sim } \\
\text { seu resultado. Há o encadeamento de quatro } \\
\text { construções passivas concernentes aos } \\
\text { madeireiros, postos na posição sintática e } \\
\text { semântica de pacientes (sujeito de passiva). } \\
\text { Os agentes do processo não são } \\
\text { explicitados, embora previstos na grade } \\
\text { argumental desse tipo de verbo. Os agentes } \\
\text { dessas passivas são os índios kaapor. }\end{array}$ \\
\hline $\begin{array}{l}\text { Entre as fotografias, há } \\
\text { cenas de supostos } \\
\text { madeireiros amarrados e } \\
\text { cercados por homens } \\
\text { armados de paus, foices e } \\
\text { até rifles }\end{array}$ & $\begin{array}{l}\text { Arg1: cenas de } \\
\text { supostos } \\
\text { madeireiros } \\
\text { amarrados e } \\
\text { cercados por } \\
\text { homens } \\
\text { armados de } \\
\text { paus, foices e } \\
\text { até rifles }\end{array}$ & Arg1: Objeto & Arg1:Tema & Arg 1: Foco & $\begin{array}{l}\text { A topicalização de "fotografias" nos faz } \\
\text { crer que esse é um fato incontestável. Ao } \\
\text { mesmo tempo, o uso do verbo impessoal } \\
\text { protege a face do jornal que não precisa } \\
\text { citar quem tirou/ mostrou as fotos. É como } \\
\text { se as fotografias existissem por si próprias. }\end{array}$ \\
\hline 1[Um deles tenta fugir] & $\begin{array}{l}\text { Oração } 1 \\
\text { Arg1: um } \\
\text { deles } \\
\text { Oração } 2\end{array}$ & $\begin{array}{l}\text { Oração } 1 \\
\text { Arg1: Sujeito } \\
\text { Oração } 2\end{array}$ & $\begin{array}{l}\text { Oração } 1 \\
\text { Arg 1:Agente } \\
\text { Oração } 2\end{array}$ & $\begin{array}{l}\text { Oração } 1 \\
\text { Arg1: Tópico } \\
\text { Oração } 2\end{array}$ & $\begin{array}{l}\text { O madeireiro é colocado na posição de } \\
\text { sujeito nos enunciados } 1 \text { e } 2 \text {; no } 2 \text {, é } \\
\text { semanticamente paciente, e o índio é o } \\
\text { agente do processo. A escolha dos verbos }\end{array}$ \\
\hline
\end{tabular}




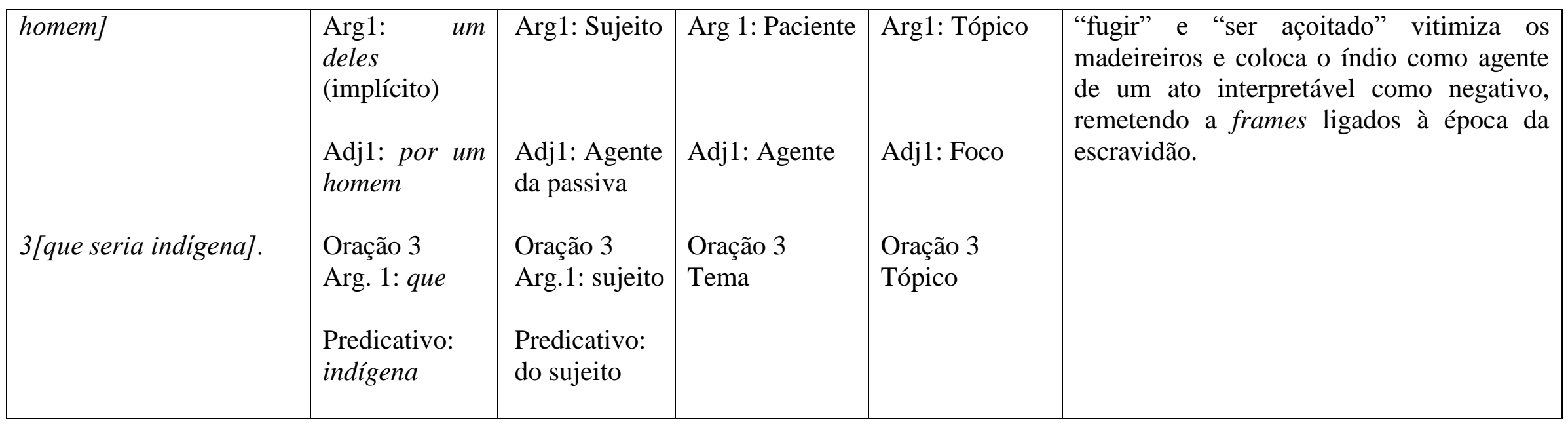

\section{A.3. Metáforas e metonímias (Notícia 2)}

\begin{tabular}{|c|c|c|}
\hline $\begin{array}{c}\text { Metáfora } \\
\text { ou } \\
\text { Metonímia }\end{array}$ & Enunciados & Análise/Síntese \\
\hline
\end{tabular}




\begin{tabular}{|l|l|l|}
\hline Metáfora & $\begin{array}{l}\text { Contra invasor, justiça com as próprias mãos }+ \\
\text { Uma ação liderada por membros da etnia Kaapor no } \\
\text { último dia 7 de agosto }+ \\
\text { uma blitz levada a cabo por Kaapors, com apoio de } \\
\text { outras quatro tribos e sem a participação de forças do } \\
\text { Estado, para prender os invasores }\end{array}$ & $\begin{array}{l}\text { Há aqui uma tentativa de comparar a ação indígena a uma organização } \\
\text { criminosa. A ação conta com uma liderança que organiza o ataque, } \\
\text { monta uma blitz, mostrando que, além de fazer justiça com as próprias } \\
\text { mãos, os indígenas tentam assumir um papel de justiceiros, pois a blitz } \\
\text { é tipicamente uma ação policial, mas pode ser interpretada como uma } \\
\text { "sucessão de ataques" (cf. Dicionário Houaiss). Tudo isso sem que haja } \\
\text { participação do Estado; portanto, ação criminosa. }\end{array}$ \\
\hline Metonímia & $\begin{array}{l}\text { Entre as fotografias, há cenas de supostos } \\
\text { madeireiros amarrados e cercados por homens } \\
\text { armados de paus, foices e até rifles }\end{array}$ & $\begin{array}{l}\text { As fotografias aqui são tomadas como realidade. Elas substituem os } \\
\text { fatos, falam por si só e parecem ser provas incontestáveis e irrefutáveis } \\
\text { de que houve violência contra os madeireiros, que aparecem amarrados } \\
\text { e rendidos. }\end{array}$ \\
\hline Metonímia & $\begin{array}{l}\text { As roupas de alguns deles teriam sido tiradas para } \\
\text { impedir que fugissem }\end{array}$ & $\begin{array}{l}\text { As roupas aqui se tornam o grande símbolo da civilidade. Tendo sido } \\
\text { privados de suas roupas, os madeireiros não podem fugir, pois apenas } \\
\text { indígenas andam sem as vestimentas adequadas. }\end{array}$ \\
\hline
\end{tabular}

\section{A.4 . Iconicidade Diagramática (Notícia 2)}

Enunciados
Tipificação
Análise/Síntese 
Uma ação liderada por membros da etnia Kaapor no último dia 7 de agosto contra madeireiros ilegais que atuam dentro da Terra Indigena Alto Turiaçu, nas imediações de Centro do Guilherme, no Noroeste do Maranhão, lançou nova luz sobre as permanentes tensões nas reservas da Amazônia Legal na região

Entre as fotografias, há cenas de supostos madeireiros amarrados e cercados por homens armados de paus, foices e até rifles
Iconicidade de quantidade e de complexidade

Iconicidade quantidade
O sujeito é atípico, muito extenso, destacando a ação das lideranças indígenas. Distancia-se o sujeito do verbo, assim ficamos apenas com uma impressão negativa da ação indígena e dificilmente recuperamos a informação de que essa ação serve para lembrarmos que existe, há muito tempo, uma série de tensões na área.

de

Há uma série de armas explicitadas na estrutura, dando a entender que os homens (que, no caso, são indígenas) estavam assustadoramente armados. 
A.5 Frames (Notícia 2)

\begin{tabular}{|c|c|c|}
\hline Enunciados & Frames & Análise/Síntese \\
\hline Justiça com as próprias mãos & $\begin{array}{l}\text { INJUSTIÇA, VIOLÊNCIA, } \\
\text { SELVAGERIA }\end{array}$ & $\begin{array}{l}\text { A expressão justiça com as próprias mãos evoca justamente oframe de INJUSTIÇA. } \\
\text { Não se deve fazer justiça com as próprias mãos, pois há instituições que cuidam da } \\
\text { justiça no nosso país. Somos levados a crer que os indígenas desrespeitaram esse } \\
\text { princípio. Normalmente, também, a expressão traz consigo uma conotação de } \\
\text { VIOLÊNCIA. A justiça com as próprias mãos costuma envolver agressões físicas e, } \\
\text { portanto, SELVAGERIA. }\end{array}$ \\
\hline Tensões permanentes & CONTINUIDADE & $\begin{array}{l}\text { O uso dessa expressão mostra que os conflitos na reserva indígena são constantes, } \\
\text { ocorrem há muito tempo, devem continuar ocorrendo e dificilmente serão solucionados } \\
\text { (topoi). Já ganharam um status de permanência. Isso pode levar ao frame de que } \\
\text { CONTINUIDADE, levando a crer que é algo comum e corriqueiro, sem necessidade } \\
\text { de intervenção ou possibilidade de solução. }\end{array}$ \\
\hline $\begin{array}{l}\text { 1. supostos madeireiros } \\
\text { amarrados, espancados e } \\
\text { deixados nus e cercados } \\
\text { por homens armados de } \\
\text { paus, foices e até rifles } \\
\text { 2. Um deles tenta fugir ee é } \\
\text { açoitado por um homem } \\
\text { que seria indigena. }\end{array}$ & $\begin{array}{l}\text { SELVAGERIA, } \\
\text { ESCRAVIDÃO, } \\
\text { GUERRA }\end{array}$ & $\begin{array}{l}\text { Essa sequência de particípios apresenta os indígenas como SELVAGENS, brutais, } \\
\text { reduzindo os madeireiros à condição de ESCRAVOS, o que é reforçado pelo } \\
\text { enunciado 2, que traz o verbo "fugir" e "ser açoitado". A forma verbal em } 1 \text { também } \\
\text { nos faz pensar apenas em um quadro estático, o fim da ação. Enxergam-se os } \\
\text { madeireiros depois da agressão, já machucados, feridos e nus. O uso da palavra } \\
\text { "supostos" leva a crer que existe a possibilidade de não serem madeireiros, o que } \\
\text { tornaria a ação dos índios kaapor mais negativa ainda, ao lidarem com supostos } \\
\text { inocentes dessa forma. } \\
\text { Por fim, o quadro todo também evoca um estado de GUERRA, com prisioneiros, } \\
\text { armas, caminhões incendiados. }\end{array}$ \\
\hline
\end{tabular}




\section{B. Eixo analítico: Discurso e Ideologia (Notícia 2)}

\begin{tabular}{|c|c|c|}
\hline Construtos & Enunciados & Análise/síntese \\
\hline Escolhas lexicais & $\begin{array}{l}\text { 1. os nativos, chamados de } \\
\text { "guardiães da floresta"; } \\
\text { 2. é açoitado; } \\
\text { 3. Amarrados, espancados e } \\
\text { deixados nus; } \\
\text { 4. Uma ação liderada. }\end{array}$ & $\begin{array}{l}\text { 1.O apelido faz alusão ao filme "Guardiões da galáxia”, lançado no Brasil um mês } \\
\text { antes da publicação dessa notícia. Importante lembrar que, no filme, os guardiões } \\
\text { da galáxia eram alienígenas, e não humanos. A princípio, pode-se pensar que a } \\
\text { escolha lexical tem como objetivo enobrecer o indígena, mas, na verdade, a } \\
\text { motivação parece ser irônica e pejorativa. } \\
\text { 2.A escolha por "açoitado" remete aos tempos de escravidão em que negros eram } \\
\text { torturados, deixados nus para serem açoitados por seus senhores. } \\
\text { 3.O uso do particípio faz com que o quadro mental seja estático. Enxergamos o } \\
\text { momento em que a agressão acaba, e os madeireiros continuam machucados e nus. } \\
\text { 4. Novamente, a expressão "ação liderada" pode induzir o leitor a pensar que os } \\
\text { indígenas faziam parte de uma organização criminosa e que premeditaram toda a } \\
\text { ação. }\end{array}$ \\
\hline Topoi & $\begin{array}{l}\text { Como todas as reservas de } \\
\text { grande extensão, é de difícil } \\
\text { monitoramento e acaba sendo } \\
\text { alvo fácil de traficantes de } \\
\text { madeira. }\end{array}$ & $\begin{array}{l}\text { O argumento de que a área é muito extensa e de difícil contestação exime de culpa } \\
\text { quem deveria monitorá-la (o Estado). Assim, parece que caberia aos indígenas } \\
\text { entender que, de vez em quando, madeireiros exercerão suas atividades ilegais na } \\
\text { reserva e que é complicado controlá-los. Esse é um lugar-comum bastante } \\
\text { prejudicial para as populações indígenas e nosso meio ambiente. }\end{array}$ \\
\hline Modalização & $\begin{array}{l}\text { (...) os membros da tribo } \\
\text { dizem estar cansados de pedir } \\
\text { ajuda às autoridades e à } \\
\text { Fundação Nacional do Índio } \\
\text { (Funai) }\end{array}$ & $\begin{array}{l}\text { No único momento da notícia em que se apresenta o discurso dos kaapor, o jornal } \\
\text { optou pela forma indireta e usou o verbo dicendi menos confiável: dizer. Esse } \\
\text { verbo se gramaticalizou fortemente no Português em estruturas modais que } \\
\text { avaliam como imprecisas, incertas, inseguras as informações retransmitidas: Diz } \\
\text { que o Temer vai consertar o Brasil. Dizem que o futebol brasileiro vai voltar a } \\
\text { brilhar. Dizem que todas as terras indigenas serão demarcadas em breve... }\end{array}$ \\
\hline Evidencialidade & $\begin{array}{lr}\text { 1. Imagens divulgadas } \\
\text { ontem pela agência de } \\
\text { notícias } \\
\text { Reuteurs }\end{array}$ & $\begin{array}{l}\text { 1. A fonte da informação é uma agência bastante respeitada no meio publicitário. } \\
\text { Como a própria agência informa em sua página na internet: }\end{array}$ \\
\hline
\end{tabular}




\begin{tabular}{|c|c|c|}
\hline & $\begin{array}{l}\text { 2. De acordo com o } \\
\text { fotógrafor Lunaé } \\
\text { Parracho, que } \\
\text { registrou a operação } \\
\text { dos indios para a } \\
\text { agência inglesa (...) } \\
\text { 3. Em nota ao site G1, o } \\
\text { órgão federal [Funai] } \\
\text { disse ainda que "tem } \\
\text { conhecimento dessas } \\
\text { ações e já solicitou } \\
\text { apoio policial para } \\
\text { evitar que ocorram } \\
\text { excessosou conflitos" }\end{array}$ & $\begin{array}{l}\text { "A Thomson Reuters é a maior agência internacional de notícias e multimídia do } \\
\text { mundo, fornecendo notícias do mundo, investimentos, negócios, tecnologia, } \\
\text { manchetes, pequenos negócios, alertas, finanças pessoais, mercados acionários e } \\
\text { informações de fundos mútuos disponíveis através do Reuters.com, pelo celular, } \\
\text { de vídeos e de plataformas interativas de televisão. Os jornalistas da Thomson } \\
\text { Reuters estão sujeitos ao Editorial Handbook, que exige apresentação justa e } \\
\text { divulgação de interesses relevantes." } \\
\text { (fonte: http://br.reuters.com/, acessada em } 18 \text { de maio de 2016) } \\
\text { Logo, o uso dessa fonte pretende dar à notícia um alto grau de confiabilidade, } \\
\text { respeitabilidade e relevância. } \\
\text { 2. A referência direta e nominal ao fotógrafo e a seu relato somada à rotulação } \\
\text { "agência inglesa" também pretende dar à notícia ares de muito valor e importância, } \\
\text { tendo em vista os frames que esses referentes acionam em nossas mentes. }\end{array}$ \\
\hline Tópico & $\begin{array}{l}\text { 1. Contra invasor, justiça com } \\
\text { as próprias mãos; } \\
\text { 2. imagens mostram uma blitz } \\
\text { levada a cabo por kaapors; }\end{array}$ & $\begin{array}{l}\text { 1. A manchete informa qual é o tema da notícia: alguém está cometendo crimes ao } \\
\text { agir às margens da justiça. Ao ler o lead, esse alguém é identificado: índios. } \\
\text { 2 e 3: Sem dúvidas, a notícia está preocupada com a imagem do Brasil pelo mundo. } \\
\text { Não é uma preocupação com os madeireiros invasores e destruidores de terras }\end{array}$ \\
\hline
\end{tabular}




\begin{tabular}{|c|c|c|}
\hline & $\begin{array}{l}\text { 3. as imagens de ontem } \\
\text { correram o mundo e foram } \\
\text { publicadas em portais de } \\
\text { noticias internacionais. }\end{array}$ & $\begin{array}{l}\text { indígenas; a preocupação é com índios considerados pela mídia como selvagens e } \\
\text { sua atuação contra a justiça. }\end{array}$ \\
\hline Contexto & & $\begin{array}{l}\text { Como dissemos na análise da primeira notícia, o contexto social brasileiro é repleto } \\
\text { de conflitos envolvendo várias etnias indígenas em ações ilegais praticadas contra } \\
\text { elas por madeireiros, garimpeiros, fazendeiros e outros eiros que colocam em risco } \\
\text { a vida dessas etnias e do próprio meio ambiente brasileiro como um todo. }\end{array}$ \\
\hline $\begin{array}{l}\text { Racismo do dia a } \\
\text { dia }\end{array}$ & $\begin{array}{l}\text { 1.É açoitado } \\
\text { 2. Deixados nus }\end{array}$ & $\begin{array}{l}\text { São maneiras de dizer que os indígenas são primitivos e violentos, que agem como } \\
\text { senhores de escravos. Isso reforça a falsa premissa de que os indígenas fazem parte } \\
\text { de uma cultura atrasada. Muitos lerão essa notícia e dirão que a escravidão é algo } \\
\text { primitivo e que a sociedade não indígena abandonou essa prática há muitos anos. } \\
\text { Sabemos que até hoje existem situações análogas às de escravidão, mas que são } \\
\text { mascaradas e raramente vêm à público. } \\
\text { Além disso, em } 2 \text {, o fato de os indígenas terem deixado os madeireiros nus é motivo } \\
\text { de reprovação, pois estamos acostumados a uma sociedade que exige um certo } \\
\text { pudor. Ser deixado nu por um indígena é sinal de humilhação. } \\
\text { A notícia como um todo na verdade é uma amostra clara de como o racismo do dia } \\
\text { a dia impede que os indígenas assumam uma posição discursiva diferente da } \\
\text { posição de criminosos. Mesmo tendo seus direitos violados, eles são representados } \\
\text { como os fora da lei. }\end{array}$ \\
\hline $\begin{array}{l}\text { Implicações/ } \\
\text { Pressuposições }\end{array}$ & $\begin{array}{l}\text { Contra invasor, justiça } \\
\text { com as próprias mãos }\end{array}$ & $\begin{array}{l}\text { Está pressuposto que a voz é ativa e que os indígenas é que fizeram justiça, sem } \\
\text { esperar a ação dos órgãos competentes. Pressupõe-se também que eles fizeram uso } \\
\text { da violência. }\end{array}$ \\
\hline $\begin{array}{l}\text { Sinônimos/ } \\
\text { Paráfrases }\end{array}$ & $\begin{array}{l}\text { 1. Membros da etnia Kaapor } \\
\quad \text { 2. Kaapors } \\
\text { 3. Tribos } \\
\text { 4. Indios } \\
\text { 5. Homem que seria indígena }\end{array}$ & $\begin{array}{l}\text { Percebemos que os sinônimos partem do particular (etnia Kaaapor) para um } \\
\text { significado mais genérico (indígena), que predomina no texto. No exemplo 5, } \\
\text { parece que as atribuições "homem" e "indígena" não combinam, havendo uma } \\
\text { opção pela forma verbal "seria". Por último, em 7, quando se opta por denominar } \\
\text { os indígenas como "guardiões da floresta", há uma aparente tentativa de enaltecer }\end{array}$ \\
\hline
\end{tabular}




\begin{tabular}{|c|c|c|}
\hline & $\begin{array}{l}\text { 6. Indígenas } \\
\text { 7. Guardióes da floresta }\end{array}$ & $\begin{array}{l}\text { a ação indígena, que é destruída pelo contexto sociocultural, já que o filme } \\
\text { Guardiões da galáxia está em cartaz nos cinemas. }\end{array}$ \\
\hline Disclaimers & a notícia como um todo & $\begin{array}{l}\text { Repetimos aqui a mesma análise feita para a notícia 1. A notícia como um todo é } \\
\text { um exemplo de disclaimer, especificamente do tipo Inversão, culpando a vítima } \\
\text { (cf. seção 2.2.7): os povos indígenas eram, historicamente, os donos das terras } \\
\text { brasílicas, sendo os não-indígenas, aqui chegados com Cabral a partir de 1500, os } \\
\text { usurpadores de suas terras e riquezas; a notícia, porém, inverte esses papeis, } \\
\text { transformando algozes em vítimas (os madeireiros, nesse caso), e vítimas em } \\
\text { algozes (os índios kaapor). }\end{array}$ \\
\hline Coerência local & 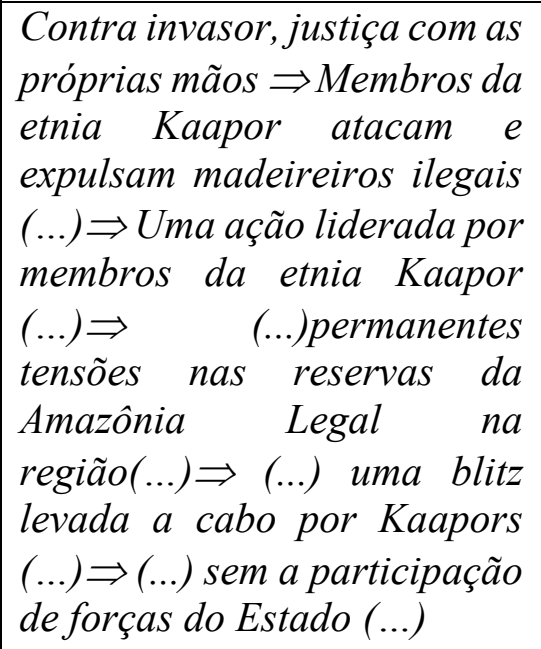 & $\begin{array}{l}\text { Desde a manchete, há um predomínio da ideia de que os indígenas Kaapor estão } \\
\text { sendo violentos, atacando e machucando pessoas, e se negam a esperar quem } \\
\text { deveria assumir a responsabilidade pela justiça. Existe a ideia de que eles estão } \\
\text { sendo autoritários, formando lideranças, montando blitz para prender pessoas, e } \\
\text { que o conflito é constante na região onde moram comunidades indígenas. Na } \\
\text { notícia, a coerência local construída revela um indígena comparável a um senhor } \\
\text { de escravos, enquanto os madeireiros ilegais são postos em uma posição de } \\
\text { vítimas. }\end{array}$ \\
\hline Contraste & $\begin{array}{l}\text { armados de paus, foices e até } \\
\text { rifles } \\
\text { dispõem de caminhões } e \\
\text { tratores }\end{array}$ & $\begin{array}{l}\text { Aqui, a ideia é de que os Kaapor estão preparados para uma verdadeira guerra. Eles } \\
\text { pegam em armas para ameaçar os madeireiros que estão desarmados. A única } \\
\text { menção é de que os madeireiros tinham acesso a caminhões e tratores, mas não } \\
\text { necessariamente faziam uso desses. Madeireiros ilegais e toda sorte de outros } \\
\text { invasores de terras indígenas são extremamente violentos e usam armas de fogo. } \\
\text { Esse é um fato social bastante conhecido também, mas que foi ignorado na notícia. }\end{array}$ \\
\hline $\begin{array}{l}\text { Exemplos/ } \\
\text { Ilustrações }\end{array}$ & & $\begin{array}{l}\text { Não conseguimos encontrar os hiperlinks da matéria ou outros hiperlinks a ela } \\
\text { associados. }\end{array}$ \\
\hline
\end{tabular}




\begin{tabular}{|c|c|c|}
\hline Vaguidade & $\begin{array}{l}\text { 1. Em nota ao site de notícias } \\
\text { G1, o órgão federal disse } \\
\text { ainda que "tem conhecimento } \\
\text { dessas ações e já solicitou } \\
\text { apoio policial para evitar que } \\
\text { ocorram excessos ou } \\
\text { conflitos" } \\
\text { 2. há cenas de supostos } \\
\text { madeireiros amarrados(...) }\end{array}$ & $\begin{array}{l}\text { 2. Uma incerteza que atravessa a notícia é se aquelas pessoas que estavam presas } \\
\text { eram madeireiros. Isso torna a ação dos Kaapor mais questionável ainda. Não há, } \\
\text { na notícia, vaguidade quanto à autoria das ações que beiram à escravidão. Mas a } \\
\text { face dos madeireiros é, de certa forma, protegida pela incerteza de serem eles } \\
\text { mesmo madeireiros de fato. }\end{array}$ \\
\hline Modelos mentais & $\begin{array}{l}\text { Indígenas são violentos, } \\
\text { matam pessoas, e ocupam } \\
\text { uma área muito extensa, que } \\
\text { poderia ser destinada à } \\
\text { agricultura. }\end{array}$ & $\begin{array}{l}\text { A notícia dá suporte à crença de que a área indígena é desnecessariamente extensa. } \\
\text { Além disso, alimenta a imagem que temos de indígenas violentos e guerreiros, que } \\
\text { não hesitam em matar, pois não se submetem às leis do país. (cf. seção A.5) }\end{array}$ \\
\hline $\begin{array}{l}\text { Modelo de } \\
\text { dominação de } \\
\text { Thompson }\end{array}$ & $\begin{array}{l}\text { 1. A Terra Indigena Alto } \\
\text { Turiaçu se estende por uma } \\
\text { área de 5.305 quilometros } \\
\text { quadrados, o que equivale a } \\
\text { mais de quatro vezes a cidade } \\
\text { do Rio de Janeiro. Como } \\
\text { todas as reservas de grande } \\
\text { extensão, é de difíil } \\
\text { monitoramento e acaba sendo } \\
\text { alvo fácil de traficantes de } \\
\text { madeira. } \\
\text { 2. Alguns dos madeireiros } \\
\text { foram espancados e } \\
\text { amarrados, e outros, deixados }\end{array}$ & $\begin{array}{l}\text { 1. Legitimação } \\
\text { a. Racionalização A comparação entre a área indígena e a cidade do Rio de } \\
\text { janeiro serve como legitimação da ação dos madeireiros. Utiliza-se um } \\
\text { raciocínio matemático para dizer ao leitor que a área indígena é } \\
\text { desproporcional; afinal, para o jornal, são poucos indígenas vivendo em } \\
\text { uma área quatro vezes maior que uma cidade bem conhecida no Brasil. } \\
\text { 2. Reificação } \\
\text { 2.1 Passivização (cf. A1) Há uma sucessão de usos de voz passiva com o sujeito } \\
\text { não agente "alguns madeireiros". O agente da passiva é previsto: indígenas kaapor. } \\
\text { A voz passiva nos traz para o primeiro plano aqueles que, segundo o texto, foram } \\
\text { violentados. Outra característica importante da voz passiva é trazer um quadro } \\
\text { mental estático, sem início nem fim. O que enxergamos é um quadro em que os } \\
\text { madeireiros já estão nus, feridos e rendidos pelos indígenas que estão armados. } \\
\text { 2.2 Eternalização O enunciado apresentado faz com que haja a ideia de que as } \\
\text { operações realizadas pelos indígenas sejam eternas. Elas começaram há algum }\end{array}$ \\
\hline
\end{tabular}




\begin{tabular}{|l|l|l|}
\hline $\begin{array}{l}\text { nus para supostamente serem } \\
\text { entregues a agentes policiais. }\end{array}$ & $\begin{array}{l}\text { tempo e continuam acontecendo, sem uma previsão para seu fim. Assim, não foram } \\
\text { apenas aqueles madeireiros que se machucaram. Muitos já foram feridos e outros } \\
\text { ainda serão. Indiretamente, a notícia induz o leitor a inverter o foco e cobrar da }\end{array}$ \\
$\begin{array}{l}2.2 . \text { A Funai informou que os } \\
\text { nativos, chamados de de }\end{array}$ & $\begin{array}{l}\text { FUNAI providências em relação à violência cometida pelos indígenas e não contra } \\
\text { eles. }\end{array}$ \\
$\begin{array}{ll}\text { "guardiões da floresta", têm } \\
\text { realizado naquela região } \\
\text { ações de apreensão de } \\
\text { madeireiros ilegais }\end{array}$ & \\
\hline
\end{tabular}

\section{Eixo analítico: Comunicação (Notícia 2)}

\section{C.1. Qual(is) o(s) critério(s) de noticiabilidade ressaltado(s)? (Notícia 2)}

\begin{tabular}{|c|c|c|}
\hline $\begin{array}{l}\text { Critérios } \\
\text { de noticiabilidade }\end{array}$ & Enunciados & Análise/síntese \\
\hline \multicolumn{3}{|l|}{ Raridade } \\
\hline Interesse nacional & $\begin{array}{l}\text { As imagens de ontem correram o } \\
\text { mundo e foram publicadas em } \\
\text { portais de notícias internacionais }\end{array}$ & $\begin{array}{l}\text { A notícia pretende ser de interesse nacional, sobretudo por destacar que o tema } \\
\text { abordado por ela "correu o mundo" e foi de interesse internacional. }\end{array}$ \\
\hline \multicolumn{3}{|l|}{$\begin{array}{l}\text { Interesse } \\
\text { pessoal/econômico }\end{array}$} \\
\hline \multicolumn{3}{|l|}{ Catástrofe } \\
\hline $\begin{array}{l}\text { Interesse } \\
\text { universal }\end{array}$ & $\begin{array}{l}\text { Alguns dos madeireiros foram } \\
\text { espacados, amarrados e outros, } \\
\text { deixados nus (...) } \\
\text { (...) há cenas de supostos } \\
\text { madeireiros amarradose cercados }\end{array}$ & $\begin{array}{l}\text { Os direitos humanos são de interesse universal e, de certo ponto de vista, estão } \\
\text { sendo ignorados pelos índios kaapor ao tratar os madeireiros ilegais como } \\
\text { descrito na notícia. Por outro lado, esses mesmos direitos humanos são direitos } \\
\text { dos povos indígenas, mas a notícia não os evoca com relação a esses grupos. }\end{array}$ \\
\hline
\end{tabular}




\begin{tabular}{|c|c|c|}
\hline & $\begin{array}{l}\text { por homens armados de paus, } \\
\text { foices e até rifles. Um deles tenta } \\
\text { fugir e é açoitado por um homem } \\
\text { que seria indigena. } \\
\text { A Funai informou (...) que já } \\
\text { solicitou apoio policial para evitar } \\
\text { que ocorram excessos ou conflitos }\end{array}$ & \\
\hline Injustiça & $\begin{array}{l}\text { Contra invasor, justiça com as } \\
\text { próprias mãos }\end{array}$ & $\begin{array}{l}\text { Sabemos que não se deve fazer justiça com as próprias mãos, pois existem regras } \\
\text { e processos que devem ser seguidos para garantirmos uma convivência pacífica } \\
\text { em sociedade. E isso é acionado em nossas mentes ao ler a notícia. Os fins não } \\
\text { justificam os meios, sobretudo se os meios forem praticados por índios em nossa } \\
\text { sociedade. Dois pesos e duas medidas, uma vez que é totalmente ilegal a invasão } \\
\text { de reservas indígenas por madeireiros e congêneres. Essa injustiça não é } \\
\text { sublinhada da mesma forma que a injustiça praticada pelos kaapor o foi na } \\
\text { notícia. }\end{array}$ \\
\hline Crime/violência & $\begin{array}{l}\text { Alguns dos madeireiros foram } \\
\text { espacados, amarrados e outros, } \\
\text { deixados nus (...) } \\
\text { (...) há cenas de supostos } \\
\text { madeireiros amarrados e cercados } \\
\text { por homens armados de paus, } \\
\text { foices e até rifles. Um deles tenta } \\
\text { fugir e é açoitado por um homem } \\
\text { que seria indigena. } \\
\text { A Funai informou (...) que já } \\
\text { solicitou apoio policial para } \\
\text { evitar que ocorram excessos ou } \\
\text { conflitos }\end{array}$ & $\begin{array}{l}\text { As ações dos kaapor são apresentadas como crimes e com alto grau de violência. } \\
\text { Sem dúvida, são questionáveis, como deveriam ser questionáveis em mesma } \\
\text { medida a ação ilegal dos madeireiros, que cometem crimes de morte, estupro e } \\
\text { outras brutalidades contra vários povos indígenas brasileiros, além de destruir o } \\
\text { meio ambiente. }\end{array}$ \\
\hline Drama & & \\
\hline
\end{tabular}




\begin{tabular}{|ll|l|l|}
\hline Proeminência & do \\
indivíduo & na & & \\
sociedade & & & \\
\hline
\end{tabular}

\section{C.2. Estrutura da notícia (Notícia 2)}

\begin{tabular}{|c|c|c|}
\hline $\begin{array}{l}\text { Estrutura } \\
\text { da notícia }\end{array}$ & Enunciados & Análise/síntese \\
\hline Manchete & $\begin{array}{l}\text { Contra invasor, justiça com as } \\
\text { próprias mãos }\end{array}$ & $\begin{array}{l}\text { A manchete não traz informações essenciais como quem, quando, onde, como ou } \\
\text { por quê, acionando o frame de maneira vaga. }\end{array}$ \\
\hline Lead & $\begin{array}{l}\text { Membros da etnia Kaapor atacam } \\
\text { e expulsam madeireiros ilegais de } \\
\text { reserva no Noroeste do Maranhão }\end{array}$ & $\begin{array}{l}\text { O lead traz a etnia, mas também é formado por dois verbos de semântica negativa } \\
\text { associados a ela. }\end{array}$ \\
\hline $\begin{array}{l}\text { Informações } \\
\text { primárias/iniciais }\end{array}$ & & $\begin{array}{l}\text { Membros de uma comunidade indígena resolveram fazer justiça com as próprias } \\
\text { mãos e expulsaram madeireiros de uma reserva indígena no Maranhão com a } \\
\text { ajuda de outras quatro tribos cuja identidade não foi revelada na notícia. }\end{array}$ \\
\hline $\begin{array}{l}\text { Informações } \\
\text { secundárias/finais }\end{array}$ & & $\begin{array}{l}\text { Os madeireiros tinham caminhões e tratores e estavam ocupando uma terra } \\
\text { indígena. Os madeireiros foram amarrados e deixados nus. A Funai disse já ter } \\
\text { conhecimento do que está ocorrendo na região. }\end{array}$ \\
\hline $\begin{array}{l}\text { Caderno/ } \\
\text { Local } \\
\text { da publicação }\end{array}$ & Sociedade & $\begin{array}{l}\text { Provavelmente, a notícia está nesse caderno e não no regional por possuir um } \\
\text { grande potencial de comover um grande número de pessoas. }\end{array}$ \\
\hline
\end{tabular}




\subsubsection{Síntese da análise textual da notícia 2}

A notícia se inicia na voz ativa, trazendo a etnia kaapor como sujeito agente de verbos semanticamente negativos (atacar e expulsar). Quando a voz é passiva, o indígena é levado a ocupar a posição de agente da passiva, sendo topicalizados na posição de sujeito os madeireiros, que passam a ser interpretados como pacientes. Segundo Payne (2011) e Givón (2001) (cf. seção 1.3), a escolha da voz passiva tem motivação discursiva. Na notícia 2, a escolha pela passiva pode provocar no leitor a interpretação de que os indígenas são os causadores de todas as transformações naquele ambiente (os agentes); logo, responsáveis pelo conflito; enquanto os madeireiros ilegais são as vítimas (os pacientes).

Logo na manchete, a topicalização do invasor pode induzir a pensar que ele é o injustiçado. Apaga-se quase que completamente qualquer traço de culpa ou atividade ilegal que ele estava exercendo. O foco recaí sobre a ação indígena (“justiça com as próprias mãos”), que deve ser alvo de análise, sendo esse o tema da notícia.

Há o uso de metáforas que, à primeira vista, parecem enaltecer a ação indígena, mas que, contextualizadas (como guardiões da floresta), estão na verdade, ironizando a ação dos kaapor.

As escolhas lexicais, como apresentadas no eixo B, colocam os indígenas com o poder bélico, enquanto os madeireiros são desarmados pelo discurso; estes possuem caminhões e tratores, socialmente reconhecíveis como instrumentos/meios de produção/trabalho. Além disso, a atividade ilegal e condenável é, no texto, associada aos kaapor principalmente, mesmo reservando-se aos madeireiros (apenas) a alcunha de "ilegais". Os madeireiros são inocentados e, sobretudo, vitimizados.

Há sempre uma proteção de face, parece que o jornalista não viu nada, obteve as informações por meio de fontes confiáveis (agência inglesa Reuteurs, fotógrafo Lunaé Parracho, nota da Funai) fotografias. O discurso indígena só é representado indiretamente, por meio do verbo "dizer", que assume um valor de baixa confiabilidade no Português na forma como foi construído: "os membros da tribo dizem estar cansados de pedir ajuda às autoridades".

O recurso de disclaimers é muito utilizado. Em momento algum, há defesa dos motivos que levaram os kaapor a atitudes questionáveis. O tema da notícia é o "índio justiceiro", que usa de "paus, foices e até rifles"; é o índio açoitador, desumano, que espanca, amarra e desnuda madeireiros em "excessos ou conflitos". Ocorre uma completa inversão de posições entre agredidos e agressores. Apaga-se, quase por completo, o grau de violência sofrida pela etnia 
kaapor e praticada por madeireiros invasores de terra e operadores de crimes bárbaros altamente questionáveis em qualquer esfera.

Justifica-se a presença dos madeireiros na reserva indígena por meio de um topoi, fazendo o leitor crer que é impossível o monitoramento de uma área tão extensa. Questiona-se, sobretudo, o tamanho da reserva ao compará-la com a cidade do Rio de Janeiro e deixa-se de lado a ideia de que todo o território brasileiro era originalmente indígena. Justifica-se a desproporção do território indígena com uma perspectiva sincrônica.

As microestruturas descritas por van Dijk (2003) são sempre utilizadas de maneira a criar um racismo do dia a dia, um preconceito naturalizado que não fica explícito no texto, que passa despercebido quando não se faz uma leitura crítica do texto.

Diferentemente da maioria das outras notícias encontradas, essa não foi publicada no caderno regional e sim na parte "sociedade". Pode-se atribuir esse fato ao grande potencial de comoção pública e já ter sido divulgada pela mídia internacional. A justiça foi feita com as próprias mãos de maneira violenta. Os indígenas atacaram vários madeireiros, que não puderam se defender e foram tratados como verdadeiros escravos, tendo sido, inclusive, deixados nus. Há constantemente uma tentativa de diminuir o papel dos madeireiros que são retratados apenas como vítimas. Há apenas a ocorrência da palavra ilegais para mostrar que eles também estavam errados. Quando se fala dos indígenas, a escolha lexical é por armados com pedras, paus, rifles; enquanto isso os madeireiros dispõem de caminhões, o que não significa que faziam uso deles.

É também atípica a manchete dessa notícia. Além de não trazer todas as principais informações, ela traz uma construção que é formada sem verbo, sem sujeito. Bonini (2004) explica que a estrutura padrão da manchete traz mais informações do que as apresentadas. Cabe ao leitor inferir qual a voz verbal seria escolhida caso todos os elementos estivessem presentes no texto. Essa construção já diz ao leitor qual interpretação seguir ao longo do restante do texto (KLEIMAN, 2003).

De acordo com van Dijk (2003, p.48), o discurso racista exige uma coerência local. Há sempre uma sequência de fatos e ações que nos levam a preencher os espaços de causa e consequência. Assim, esse encadeamento de verbos sugere sempre a ideia de que os indígenas são violentos e estão assumindo a posição das autoridades. As metáforas e metonímias sugerem sempre que a realidade é de tensão permanente nas reservas, com fotos que mostram claramente a crueldade indígena. Neste exemplo, vemos os índios armados, agressores e os madeireiros representados como vítimas, indefesas e desarmadas. O cenário construído pelo discurso é de guerra, escravidão e selvageria. 
A estrutura da notícia evidencia como a manchete, o lead e as escolhas das informações, bem como suas fontes, foram estruturados para manter a coerência entre a microestrutura e o discurso, não deixando margem para outras possíveis interpretações. De modo geral, todos os eixos de análise deixam claro uma ideologia que marginaliza o indígena, enquanto os não-índios são retratados como vítimas. 


\subsection{Análise Textual 3 - Notícia 3}

\section{Notícia 3}

\section{Indígenas Yanomami de Roraima continuam ocupando prédio da Sesai \\ Eles dizem que só saem após exoneração da coordenadora do Dsei-Y. \\ Audiência pública teria sido cancelada; MS ainda não se pronunciou.}

Há uma semana, mais de 50 indígenas da etnia Yanomami ocupam o prédio da Secretaria Especial de Saúde Indígena (Sesai) em Roraima. Eles invadiram o prédio para reivindicar a exoneração da coordenadora do Distrito Especial de Saúde Indígena Yanomami (Dsei-Y), Maria de Jesus do Nascimento, e alegam que não há remédios e atendimento médico na área indígena.

De acordo com um dos líderes do movimento, Anselmo Yanonami, os indígenas permanecem no local até a exoneração da coordenadora. Eles entraram em contato com a Sesai e estavam aguardando um posicionamento do órgão na sexta-feira (23).

"Nós conversamos com a Sesai de Brasília e eles disseram que na sexta-feira nos dariam uma resposta, mas até agora nada. Enquanto eles não responderem, não vamos sair de lá. Permaneceremos com a nossa manifestação pacífica", disse a liderança.

Segundo Anselmo Yanomami, uma audiência pública em Boa Vista, na qual estaria presente o secretário geral da Sesai, Antônio Alves, foi desmarcada por ele. "O secretário disse ter se sentido ameaçado e mandou cancelar a audiência. Não procede o medo dele. Ele pode vir para Boa Vista, pois não estamos aqui para agredir ninguém", argumentou.

Ele ressaltou ainda que mais de 300 comunidades indígenas estão a favor da manifestação e pedem melhorias nos serviços de saúde para os Yanomami. "Nós pedimos aos irmãos o apoio para a nossa causa, em prol do povo Yanomami. Pedimos a compreensão e reconhecimento da precariedade da saúde. Só quem sofre e chora conhece o que passamos", esclarece.

Apesar da ocupação do prédio, os indígenas afirmam que estão permitindo a entrada de todos os funcionários, com exceção da coordenadora Maria de Jesus. "Não estamos impedindo os funcionários de trabalhar. Só não queremos a entrada dela [coordenadora] no prédio", disse Anselmo Yanomami.

Sobre a audiência pública que teria sido cancelada pelo secretário da Sesai, o G1 entrou em contato com a assessoria de comunicação do Ministério da Saúde (MS) e aguarda resposta.

(Fonte:

< http://g1.globo.com/rr/roraima/notícia/2015/01/indigenas-yanomami-de-roraima-continuam-ocupando-predio-da-sesai.html> acesso em junho de 2015.) 


\section{A - Eixo analítico: Linguística Cognitivo-Funcional (Linguística Centrada no Uso) (Notícia 3)}

\section{A.1 Voz (stricto sensu e lato sensu)/ Valência verbal (Notícia 3)}

\begin{tabular}{|c|c|c|c|c|}
\hline Enunciados & Voz /ordem & $\begin{array}{l}\text { Valência } \\
\text { Sintática }\end{array}$ & $\begin{array}{l}\text { Valência } \\
\text { Semântica }\end{array}$ & Análise/Síntese \\
\hline $\begin{array}{l}\text { Indígenas Yanomami de } \\
\text { Roraima continuam ocupando } \\
\text { prédio da Sesai }\end{array}$ & $\begin{array}{l}\text { Voz ativa; Ordem } \\
\text { direta (SVO). }\end{array}$ & 2 & 2 & $\begin{array}{l}\text { A locução verbal continuam ocupando traz um aspecto } \\
\text { durativo e contínuo. Há um sujeito e um objeto prototípicos. } \\
\text { A voz ativa traz os indígenas Yanomami para uma posição } \\
\text { de destaque (sujeito/tópico). Eles são sujeitos de um verbo } \\
\text { com semântica negativa. }\end{array}$ \\
\hline Eles invadiram o prédio & $\begin{array}{l}\text { Voz ativa; } \text { Ordem } \\
\text { direta } \quad \text { (SVO); } \\
\text { transitividade alta }\end{array}$ & 2 & 2 & $\begin{array}{l}\text { A voz ativa e o verbo escolhido evocam um sujeito } \\
\text { [+humano, +agente, +controle]; a voz ativa aqui implica que } \\
\text { a invasão foi intencional. O enunciado é altamente transitivo } \\
\text { (cf. HOPPER \& THOMPSON, 1980). }\end{array}$ \\
\hline $\begin{array}{l}1 \text { [Eles dizem } 2 \text { [que só saem } \\
\text { após exoneração da } \\
\text { coordenadora do Dsei-Y]] }\end{array}$ & $\begin{array}{l}\text { 1. voz ativa; } \\
\text { ordem } \\
\text { (SVO); } \\
2 . \\
\text { Voz ativa; ordem } \\
\text { direta (SV); }\end{array}$ & $\begin{array}{l}\text { Oração 1: } \\
\qquad \begin{array}{l}2 \\
\text { Oração } 2:\end{array}\end{array}$ & 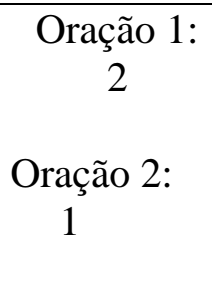 & $\begin{array}{l}\text { A voz ativa aqui é usada para construir um discurso indireto } \\
\text { a partir da fala das lideranças indígenas, o que pode provocar } \\
\text { no leitor dúvidas quanto à veracidade da informação. }\end{array}$ \\
\hline MS ainda não se pronunciou & $\begin{array}{l}\text { Voz ativa; ordem } \\
\text { direta }(\mathrm{SV}) ;\end{array}$ & 1 & 1 & $\begin{array}{l}\text { Provavelmente, se usa um verbo pronominalizado e } \\
\text { intransitivo, porque não se sabe qual a posição do ministério } \\
\text { da Saúde sobre o assunto. Temos um sujeito não prototípico, } \\
\text { uma entidade que evoca o poder público, dando uma ideia } \\
\text { de gravidade da situação. }\end{array}$ \\
\hline
\end{tabular}




\begin{tabular}{|c|c|c|c|c|}
\hline $\begin{array}{l}\text { 1[eles alegam } 2 \text { [que não há } \\
\text { remédios e atendimento } \\
\text { médico na área indígena]] }\end{array}$ & $\begin{array}{l}\text { 1. } \begin{array}{l}\text { Voz } \\
\text { ordem } \\
\text { (SVO); }\end{array} \\
\text { 2. } \\
\begin{array}{l}\text { Voz } \\
\text { ordem }\end{array} \\
\begin{array}{l}\text { (VS); indiva; } \\
\text { (VSeta }\end{array}\end{array}$ & $\begin{array}{c}\text { Oração 2: } \\
1\end{array}$ & $\begin{array}{c}\text { Oração 2: } \\
1\end{array}$ & $\begin{array}{l}\text { 1. O verbo alegar, rotineiramente, é usado para diminuir o } \\
\text { valor de verdade do que se pronuncia. A voz ativa aqui } \\
\text { também traz os indígenas como fonte da informação, } \\
\text { colocando em xeque mais uma vez a veracidade das } \\
\text { motivações da invasão. } \\
\text { 2. A escolha de um verbo com valência } 1 \text { permite que o } \\
\text { jornal retire do texto quem seria o responsável por } \\
\text { fornecer saúde e remédios para a comunidade indígena. }\end{array}$ \\
\hline $\begin{array}{l}1 \text { [ [Segundo Anselmo } \\
\text { Yanomami, uma audiência } \\
\text { pública em Boa Vista, 2[na } \\
\text { qual estaria presente o } \\
\text { secretário geral da Sesai, } \\
\text { Antônio Alves,] foi } \\
\text { desmarcada por ele]. }\end{array}$ & $\begin{array}{l}\text { 1. VOz passiva; } \\
\text { ordem direta (SV) } \\
\text { com adjunto } \\
\text { deslocado à } \\
\text { esquerda; } \\
2 . \quad \text { voz ativa; } \\
\text { ordem indireta } \\
\text { (VS); } \\
\text { transitividade } \\
\text { baixa }\end{array}$ & $\begin{array}{c}\text { Oração 1: } \\
1\end{array}$ & $\begin{array}{c}\text { Oração 1: } \\
2\end{array}$ & $\begin{array}{l}\text { 1. A voz passiva e o adjunto deslocado para a esquerda tiram } \\
\text { da posição de tópico quem desmarcou a audiência pública. } \\
\text { O agente da passiva aparece em sua posição prototípica, } \\
\text { no final do enunciado, com posição e função sintática de } \\
\text { baixa relevância discursiva portanto. A ordem indireta } \\
\text { mostra que é mais importante revelar a fonte da } \\
\text { informação, eximindo a jornal do valor de verdade do que } \\
\text { é narrado. } \\
\text { 2. A voz ativa aparece também nesse período, referindo-se } \\
\text { ao secretário geral da Sesai, mas ele vem após o verbo, em } \\
\text { posição final (VS). }\end{array}$ \\
\hline
\end{tabular}


A.2. Relações gramaticais/ Papéis Semânticos/ Papéis Pragmáticos (Notícia 3)

\begin{tabular}{|c|c|c|c|c|c|}
\hline Enunciados & $\begin{array}{l}\text { Argumentos/ } \\
\text { Adjuntos }\end{array}$ & $\begin{array}{c}\text { RG ou } \\
\text { Adjuntos }\end{array}$ & $\begin{array}{c}\text { Papel } \\
\text { Semântico }\end{array}$ & $\begin{array}{c}\text { Papel } \\
\text { Pragmático }\end{array}$ & Análise/Síntese \\
\hline $\begin{array}{lr}\text { Indígenas } & \text { Yanomami de } \\
\text { Roraima } & \text { continuam } \\
\text { ocupando prédio da Sesai }\end{array}$ & $\begin{array}{l}\text { Arg1: } \\
\text { Indigenas } \\
\text { Yanomami } \\
\text { Arg 2: Prédio } \\
\text { da Sesai }\end{array}$ & $\begin{array}{l}\text { Arg 2: Objeto } \\
\text { direto }\end{array}$ & Arg 2:Paciente & Arg 1: Tópico & $\begin{array}{l}\text { Alinhamento prototípico. O sujeito é } \\
\text { humano, enquanto o objeto é inanimado. O } \\
\text { indígena é colocado em posição de sujeito } \\
\text { agente e de tópico com uma semântica } \\
\text { verbal negativa. O objeto é inanimado, sem } \\
\text { volição, prototípico. Podemos nos } \\
\text { questionar, porém, se os indígenas } \\
\text { ocupavam todo o prédio ou apenas parte } \\
\text { dele. }\end{array}$ \\
\hline Eles invadiram o prédio & $\begin{array}{l}\text { Arg 1: Eles } \\
\text { Arg2: O prédio }\end{array}$ & $\begin{array}{l}\text { Arg 1: Sujeito } \\
\text { Arg 2: Objeto } \\
\text { direto }\end{array}$ & $\begin{array}{l}\text { Arg 1: Agente } \\
\text { Arg 2: Paciente }\end{array}$ & $\begin{array}{l}\text { Arg 1: Tópico } \\
\text { Arg 2: Foco }\end{array}$ & $\begin{array}{l}\text { O alinhamento é, também, prototípico, com } \\
\text { um sujeito humano, agente e com controle } \\
\text { sobre suas ações e um objeto inanimado. } \\
\text { Novamente, o indígena é colocado como } \\
\text { sujeito agente e tópico em uma oração com } \\
\text { semântica negativa. }\end{array}$ \\
\hline $\begin{array}{l}\text { 1. [Eles dizem } \\
\text { 2. [que só saem após } \\
\text { exoneração } \\
\text { coordenadora do Dsei- } \\
\text { Y]] }\end{array}$ & $\begin{array}{l}\text { Oração 1: } \\
\text { Arg 1: Eles } \\
\text { Arg 2: que só } \\
\text { saem após } \\
\text { exoneração da } \\
\text { coordenadora } \\
\text { do Dsei-Y } \\
\text { Oração 2: } \\
\text { Arg 1: (eles) }\end{array}$ & $\begin{array}{l}\text { Oração 1: } \\
\text { Arg 1: Sujeito } \\
\text { Arg 2: Objeto } \\
\text { direto } \\
\text { oracional } \\
\text { Oração 2: } \\
\text { Arg 1: sujeito }\end{array}$ & $\begin{array}{l}\text { Oração 1: } \\
\text { Arg 1: Agente } \\
\text { Arg 2: Tema }\end{array}$ & $\begin{array}{l}\text { Oração 1: } \\
\text { Arg 1: Tópico } \\
\text { Arg 2. Foco }\end{array}$ & $\begin{array}{l}\text { 1. O sujeito/tópico é um agente não } \\
\text { prototípico, uma vez que não produz um } \\
\text { efeito sobre um dado paciente; o verbo é } \\
\text { do tipo dicendi, que reporta o discurso de } \\
\text { outro indiretamente. Esse verbo já se } \\
\text { gramaticalizou em outra função no } \\
\text { Português do Brasil: modalidazar uma } \\
\text { informação dada, avaliando-a como } \\
\text { imprecisa ou menos segura. Certamente, } \\
\text { esse valor acaba sendo acionado pelo } \\
\text { leitor também. } \\
\text { 2. Na oração 2, há uma marcação formal de } \\
\text { tempo, mas implica uma condição: eles só }\end{array}$ \\
\hline
\end{tabular}




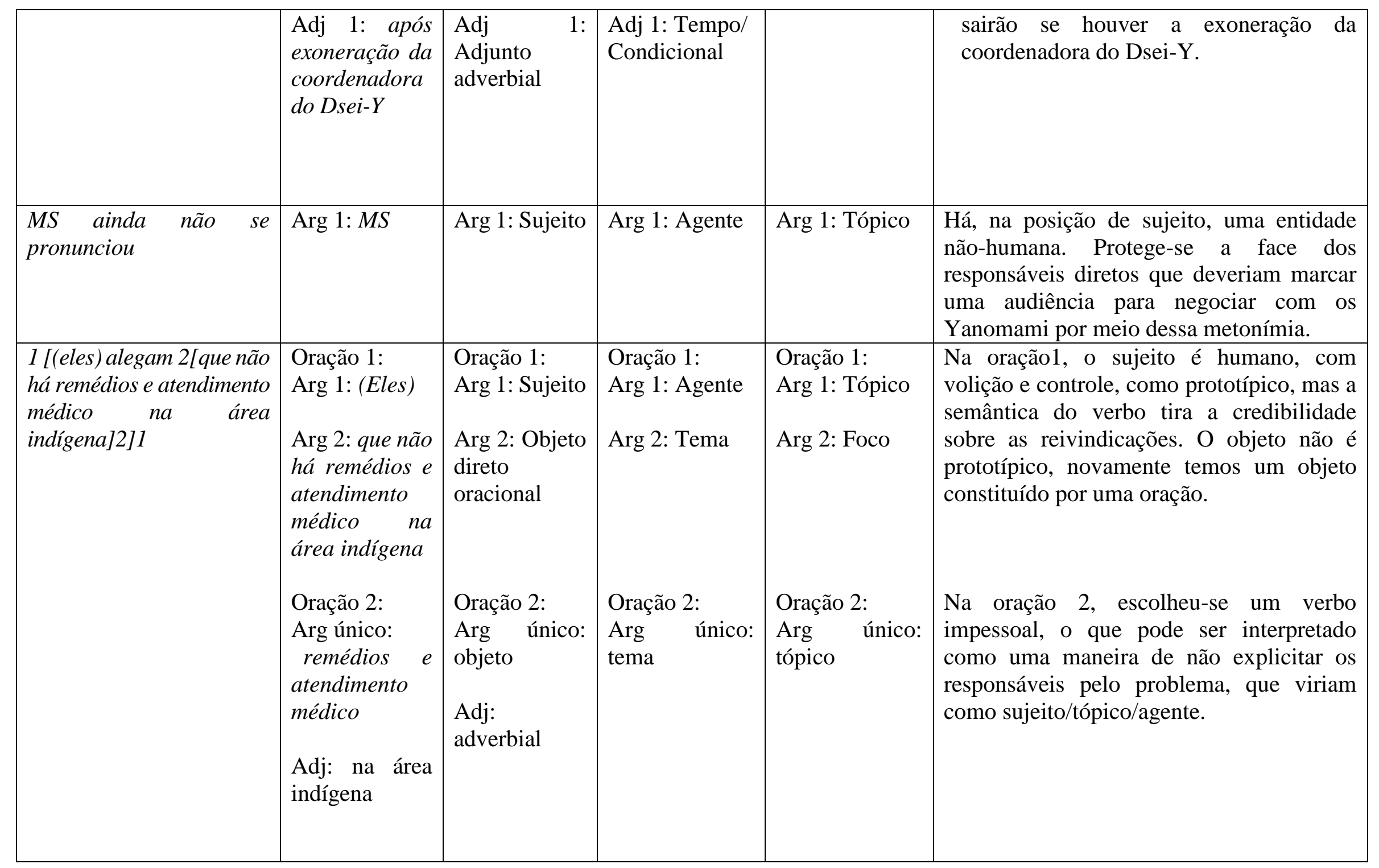




\begin{tabular}{|c|c|c|c|c|c|}
\hline $\begin{array}{l}\text { [Segundo Anselmo } \\
\text { Yanomami, uma audiência } \\
\text { uública em Boa Vista, 2[na } \\
\text { qual estaria presente o } \\
\text { secretário geral da Sesai, } \\
\text { Antônio Alves,]2 foi } \\
\text { desmarcada por ele]1. }\end{array}$ & $\begin{array}{l}\text { Oração 1: } \\
\text { Adj1: Segundo } \\
\text { Anselmo } \\
\text { Yanomami } \\
\text { Arg 1: Uma } \\
\begin{array}{l}\text { audiência } \\
\text { publica }\end{array} \\
\begin{array}{l}\text { Adj 2: em Boa } \\
\text { vista }\end{array} \\
\begin{array}{l}\text { Adj3: por ele } \\
\text { Oração 2: } \\
\text { Arg único: } \\
\text { o secretário } \\
\text { geral da Sesai }\end{array}\end{array}$ & $\begin{array}{l}\text { Adj2: } \\
\text { adverbial } \\
\text { Adj3: } \\
\text { adverbial } \\
\text { Oração 2: } \\
\begin{array}{l}\text { Arg único: } \\
\text { sujeito }\end{array}\end{array}$ & $\begin{array}{l}\text { Adj2: Lugar } \\
\text { Adj3: Agente } \\
\text { Oração 2: } \\
\text { Arg único: } \\
\text { tema }\end{array}$ & Arg 1: Tópico & $\begin{array}{l}\text { Topicaliza-se a liderança indígena para } \\
\text { proteção de face. A informação foi dada por } \\
\text { ele; assim, o jornal pode se eximir da } \\
\text { responsabilidade. Há um sujeito paciente, o } \\
\text { que é prototípico da voz passiva, mas nesse } \\
\text { caso, é um recurso para destacarmos a } \\
\text { audiência e tirarmos da posição de destaque } \\
\text { quem é o agente e, de fato, a desmarcou: o } \\
\text { secretário geral da Sesai. }\end{array}$ \\
\hline
\end{tabular}




\section{A.3. Metáforas e metonímias (Notícia 3)}

\begin{tabular}{|c|c|c|}
\hline $\begin{array}{c}\text { Metáfora } \\
\text { ou } \\
\text { Metonímia }\end{array}$ & Enunciados & Análise/Síntese \\
\hline Metáfora & $\begin{array}{l}\text { Há uma semana, mais de } 50 \text { indígenas da etnia } \\
\text { Yanomami ocupam o prédio da Secretaria Especial de } \\
\text { Saúde Indígena (Sesai) em Roraima. Eles invadiram o } \\
\text { prédio (...) } \\
\text { Apesar da ocupação do prédio, os indígenas afirmam } \\
\text { que estão permitindo a entrada de todos os } \\
\text { funcionários, com exceção da coordenadora Maria de } \\
\text { Jesus. }\end{array}$ & $\begin{array}{l}\text { Ocupar e invadir evocam a metáfora da GUERRA. É como se } \\
\text { novamente (cf. notícia 2), os indígenas quisessem ocupar uma posição } \\
\text { autoritária, montando uma espécie de barreira, controlando entradas e } \\
\text { saídas. }\end{array}$ \\
\hline Metonímia & $\begin{array}{l}\text { Indígenas Yanomami de Roraima continuam ocupando } \\
\text { prédio da Sesai }\end{array}$ & $\begin{array}{l}\text { O prédio da Sesai é tomado como a parte ocupada, quando, na verdade, } \\
\text { não sabemos qual a real proporção de ocupação indígena. Seria apenas } \\
\text { a entrada? O prédio todo? Um andar? } \\
\text { Nesse enunciado, ainda notamos que o todo é tomado pela parte quando } \\
\text { se diz "Indígenas Yanomami de Roraima". São todos os indígenas dessa } \\
\text { comunidade? Essa metonímia pode ter sido utilizada logo na manchete } \\
\text { para estimular o leitor a pensar em um número bastante alto de } \\
\text { indígenas. }\end{array}$ \\
\hline Metonímia & MS ainda não se pronunciou & $\begin{array}{l}\text { MS ocupa o lugar da parte, da pessoa que deveria se pronunciar. Em vez } \\
\text { disso, coloca-se o ministério para que não seja preciso citar nomes. }\end{array}$ \\
\hline
\end{tabular}




\section{A.4 . Iconicidade Diagramática (Notícia 3)}

\begin{tabular}{|l|l|l|}
\hline \multicolumn{1}{|c|}{ Enunciados } & Tipificação & \multicolumn{1}{|c|}{ Análise/Síntese } \\
\hline $\begin{array}{l}\text { os indígenas afirmam que estão } \\
\text { permitindo a entrada de todos os } \\
\text { funcionários }\end{array}$ & $\begin{array}{l}\text { Iconicidade de } \\
\text { complexidade }\end{array}$ & $\begin{array}{l}\text { O uso de uma causativa lexical (permitindo) mostra que houve uma tomada do } \\
\text { poder pelos indígenas que agora decidem quem pode trabalhar ou não. Há uma } \\
\text { relação direta entre entrar e sair do prédio com os indígenas. Não há meio-termo } \\
\text { ou outra maneira de se entrar/ sair. }\end{array}$ \\
\hline $\begin{array}{l}\text { Indígenas Yanomami de Roraima } \\
\text { continuam ocupando prédio da Sesai }\end{array}$ & $\begin{array}{l}\text { Iconicidade de } \\
\text { quantidade }\end{array}$ & $\begin{array}{l}\text { A locução verbal está expressando um aspecto contínuo da ação. Não se consegue } \\
\text { enxergar nem o início da ação nem seu fím. }\end{array}$ \\
\hline
\end{tabular}

\section{A.5 Frames (Notícia 3)}

\begin{tabular}{|l|l|l|}
\hline \multicolumn{1}{|c|}{ Enunciados } & \multicolumn{1}{|c|}{ Frames } & \multicolumn{1}{c|}{ Análise/Síntese } \\
\hline $\begin{array}{l}\text { Indigenas Yanomami de Roraima } \\
\text { continuam ocupando prédio da Sesai }\end{array}$ & INVASÃO & $\begin{array}{l}\text { O estereótipo acionado é que indígenas costumam ocupar prédios públicos } \\
\text { por muito tempo. O uso de um aspecto mais durativo no verbo nos leva a } \\
\text { crer que a ocupação já ocorre há algum tempo. Não é possível enxergar o } \\
\text { começo nem o fim da ação. Isso contribui para a manutenção da ideologia } \\
\text { da reificação/continuidade (cf. THOMPSON, 1995). }\end{array}$ \\
\hline Eles invadiram o prédio & VIOLÊNCIA/ INJUSTIÇA & $\begin{array}{l}\text { O verbo invadir evoca normalmente atos violentos e agressivos. } \\
\text { Dificilmente, imaginamos uma invasão em que não haja o uso da violência } \\
\text { física e intimidação. Ao mesmo tempo, o conceito de invasão remete ao } \\
\text { conceito de injustiça: um invasor se apossa de algo que não é dele, } \\
\text { utilizando a força. }\end{array}$ \\
\hline $\begin{array}{l}\text { Não procede o medo dele } \\
\text { Não estamos aqui para agredir } \\
\text { ninguém }\end{array}$ & MEDO & \begin{tabular}{l} 
Indios provocam medo por suas atitudes tipificadas como violentas e selvagens. \\
\hline
\end{tabular} \\
\hline
\end{tabular}


B. Eixo analítico: Discurso e Ideologia (Notícia 3)

\begin{tabular}{|c|c|c|}
\hline Construtos & Enunciados & Análise/síntese \\
\hline Escolhas lexicais & $\begin{array}{l}\text { 1. Indígenas Yanomami/ } \\
\text { indigenas } \\
\text { 2. Continuam ocupando/ } \\
\text { invadiram; } \\
\text { 3. Alegam / dizem/disse }\end{array}$ & $\begin{array}{l}\text { 1. Há especificação da etnia, algo raro em notícias; mesmo assim, a notícia ainda } \\
\text { se utiliza da expressão "indígenas" como referência aos Yanomami; } \\
\text { 2. Verbos com semântica tipicamente negativa, principalmente o verbo invadir; } \\
\text { 3. Esses verbos possibilitam uma leitura de descredibilidade em relação às } \\
\text { declarações indígenas. }\end{array}$ \\
\hline Topoi & $\begin{array}{l}\text { Eles invadiram o prédiol } \\
\text { não procede o medo delel } \\
\text { não estamos aqui para } \\
\text { agredir ninguém }\end{array}$ & $\begin{array}{l}\text { Índios são invasores, agressores e causam medo. O discurso direto coloca na } \\
\text { própria voz do índio Yanomami esses lugares-comuns. }\end{array}$ \\
\hline Modalização & $\begin{array}{l}\text { 1. Audiência pública teria sido } \\
\text { cancelada; } \\
\text { 2. (os Yanomami) alegam que } \\
\text { (...)/ dizem que (...) }\end{array}$ & $\begin{array}{l}\text { 1. A modalização aqui sugere que a informação não é plenamente confiável. } \\
\text { 2. "alegar" conota à informação um valor de verdade questionável; "diz que" } \\
\text { também diminui o valor de verdade da proposição. }\end{array}$ \\
\hline Evidencialidade & $\begin{array}{l}\text { Discurso direto e discurso } \\
\text { indireto abundante }\end{array}$ & $\begin{array}{l}\text { Há o uso abundante de discurso direto, trazendo a voz do Yanomami para a notícia. } \\
\text { Também se utiliza o discurso indireto fortemente para isso. O texto, do início (lead) } \\
\text { ao fim, alterna entre discurso direto e indireto. A fonte da informação é dada direta } \\
\text { ou indiretamente justamente quando o valor da informação precisará ser avaliado } \\
\text { pelo leitor. } \\
\text { Tendo em vista que a fonte é o indígena Yanomami, que valor de verdade será } \\
\text { efetivamente dado ao que ele diz? Socialmente, o valor atribuído aos indígenas em } \\
\text { geral é negativo. Logo, afirmações vindas dele serão avaliadas de acordo com esse } \\
\text { valor. }\end{array}$ \\
\hline Tópico & & $\begin{array}{l}\text { O tema do texto é ocupação/invasão de prédio público por indígenas Yanomami. } \\
\text { A causa da invasão é dada perifericamente na notícia. Assim, aparece como tópico } \\
\text { dessa notícia invasão. Esse tópico se sobrepões inclusive ao que realmente merecia } \\
\text { destaque: a falta de saúde e recursos nas comunidades indígenas. }\end{array}$ \\
\hline
\end{tabular}




\begin{tabular}{|c|c|c|}
\hline Contexto & O texto como um todo & $\begin{array}{l}\text { Os povos indígenas têm lutado constantemente por seus direitos e o } \\
\text { reconhecimento de sua capacidade de tomar decisões. Em seu discurso, após visitas } \\
\text { às comunidades indígenas em } 2014 \text {, a relatora da ONU, Victoria Tauli-Corpuz } \\
\text { afirmou que: } \\
\text { "Nesse contexto, gostaria de expressar especial preocupação relativamente aos } \\
\text { impactos sobre a saúde provocados pela mineração ilegal e pelo uso de mercúrio } \\
\text { em terras Yanomami. A situação dos Yanomamis é reflexo da intrincada relação } \\
\text { entre os direitos dos povos indígenas à saúde, educação e cultura e a efetivação de } \\
\text { seus direitos territoriais e de auto-governança". } \\
\text { Assim, percebemos que o contexto que envolve a comunidade Yanomami e muitas } \\
\text { outras é o de problemas de saúde e um descaso por parte dos órgãos que deveriam } \\
\text { tomar as devidas providências. Assim, a saída encontrada pelos indígenas é a de } \\
\text { ocupação desses espaços. }\end{array}$ \\
\hline $\begin{array}{l}\text { Racismo do dia a } \\
\text { dia }\end{array}$ & & $\begin{array}{l}\text { O texto como um todo é um exemplo claro de como ocorre o racismo do dia a dia. } \\
\text { O indígena é tratado como invasor, e essa é uma ideia que já se naturalizou no } \\
\text { imaginário da população brasileira. }\end{array}$ \\
\hline $\begin{array}{l}\text { Implicações/ } \\
\text { Pressuposiçōes }\end{array}$ & $\begin{array}{l}\text { I. Indígenas Yanomami } \\
\text { continuam ocupando prédio } \\
\text { da Sesai. } \\
\text { 2. o secretário disse ter se } \\
\text { sentido ameaçado e mandou } \\
\text { cancelar a audiência. Não } \\
\text { procede o medo dele. Ele pode } \\
\text { vir para Boa Vista, pois não } \\
\text { estamos aqui para agredir } \\
\text { ninguém, argumentou. } \\
\text { 3. apesar da ocupação do } \\
\text { prédio, os indígenas afirmam } \\
\text { que estão permitindo a a } \\
\text { entrada de todos os } \\
\text { funcionários (...) }\end{array}$ & $\begin{array}{l}\text { 1. Fica pressuposto que a ocupação já dura algum tempo, que pode ser longo ou } \\
\text { curto; o uso do tempo presente e do aspecto durativo (gerúndio) tende a ser } \\
\text { intrepretado como "tempo longo"; } \\
\text { 2. Mesmo sendo discurso direto, essa fala atribuída a uma liderança Yanomami } \\
\text { pressupõe que houve manifestação anterior do secretário em que ele disse ter } \\
\text { se sentido ameaçado, com medo de ser agredido. A implicação é que há } \\
\text { possibilidade de violência por parte dos Yanomami. } \\
\text { 3. O valor da afirmação dos Yanomami é esvaziado ou colocado em suspeição, } \\
\text { tendo em vista a primeira parte da afirmação: "apesar da ocupação do prédio". } \\
\text { Fica subentendido que a afirmação que vem na sequência é questionável e até } \\
\text { inverídica. }\end{array}$ \\
\hline
\end{tabular}




\begin{tabular}{|c|c|c|}
\hline $\begin{array}{l}\text { Sinônimos/ } \\
\text { Paráfrases }\end{array}$ & $\begin{array}{l}\text { 1. Dizem/ alegam/ } \\
\text { argumentou/ esclarece }\end{array}$ & $\begin{array}{l}\text { 1. A escolha de palavras como "dizem" e "alegam" com referência ao discurso } \\
\text { indígena coloca em cheque a veracidade das informações apresentadas. Não há } \\
\text { nenhuma certeza no que é dito. O efeito provocado por "argumentou" e } \\
\text { "esclarece" é outro. } \\
\text { 2. "ocupar" e "invadir" não são sinônimos, mas aparecem no texto como se } \\
\text { fossem. Cada um ativa um conjunto de frames específico com valor variando } \\
\text { de menos negativo ("ocupar") até mais negativo ("invadir"). }\end{array}$ \\
\hline Disclaimers & a notícia como um todo. & $\begin{array}{l}\text { Novamente, a notícia como um todo é um exemplo de disclaimer, especificamente } \\
\text { do tipo Inversão, culpando a vítima (cf. seção 2.2.7): se a saúde pública dos não } \\
\text { índios é grave, pior ainda é a saúde dos povos indígenas brasileiros. Como afirmou } \\
\text { Anselmo Yanomami: "Pedimos a compreensão e reconhecimento da precariedade } \\
\text { da saúde. Só quem sofre e chora conhece o que passamos". Mas a notícia não } \\
\text { sublinha as razões que levaram os Yanomami a ocupar o prédio da Sesai. A } \\
\text { manchete e o lead, por exemplo, não abordam essas razões. Apenas no primeiro } \\
\text { parágrafo da notícia, se apresenta a razão da ocupação: "alegam que não há } \\
\text { remédios e atendimento". E, neste momento, fica a dúvida no ar: será verdade o } \\
\text { que alegam? Essa dúvida é provocada pela escolha lexical feita pelo jornal: o verbo } \\
\text { "alegar". Logo, mais uma vez, se percebe que a problemática indígena é diminuída } \\
\text { em prol de outros valores ideologicamente sustentados na notícia: invasão de bem } \\
\text { público, ameaças, medo, agressão, etc. }\end{array}$ \\
\hline
\end{tabular}




\begin{tabular}{|c|c|c|}
\hline Coerência local & $\begin{array}{l}\text { Indígenas Yanomami de Roraima } \\
\text { continuam ocupando prédio da } \\
\text { Sesai } \Rightarrow \text { Eles dizem que só } \\
\text { saem após exoneração } \Rightarrow \text { Há } \\
\text { uma semana, mais de } 50 \\
\text { indígenas da etnia Yanomami } \\
\text { ocupam } \Rightarrow \text { Eles invadiram o } \\
\text { prédio } \Rightarrow \text { alegam } \Rightarrow \text { nós não } \\
\text { vamos sair } \Rightarrow \text { ter se sentido } \\
\text { ameaçado } \Rightarrow \text { medo dele } \Rightarrow \\
\text { para agredir } \Rightarrow \text { apesar da } \\
\text { ocupação } \Rightarrow \text { os indígenas } \\
\text { afirmam que estão permitindo } \\
\Rightarrow \text { não queremos a entrada } \\
\text { dela }\end{array}$ & $\begin{array}{l}\text { Existe um encadeamento de ideias que afirmam que os indígenas estão invadindo } \\
\text { um prédio, causando prejuízo e exigindo a exoneração de uma funcionária. A } \\
\text { ocupação, em todas essas estruturas, dura muito tempo, gerou medo de agressão } \\
\text { no secretário geral da Sesai. A ocupação também está impedindo a entrada de } \\
\text { funcionários e, implicitamente, o bom andamento dos serviços públicos. Enfim, o } \\
\text { texto é bastante coerente internamente, tendo forjado uma leitura bastante negativa } \\
\text { sobre as ações dos Yanomami. }\end{array}$ \\
\hline Contraste & $\begin{array}{l}\text { Indígenas Yanomami/ eles/ } \\
X \\
\text { Coordenadora do Dsei- } \\
\text { Y/secretário geral da Sesai/ } \\
\text { funcionários/ Ministério da } \\
\text { Saúde }\end{array}$ & $\begin{array}{l}\text { Há clara polarização entre os índios Yanomami de um lado e os não índios de } \\
\text { outro. O texto sugere que uma etnia está contra o poder público instituído (uma } \\
\text { coordenadora e um secretário geral. Chegam a estar contra um Ministério inteiro, } \\
\text { o MS, uma vez que aguardam sua manifestação sobre o caso. Novamente, em mais } \\
\text { uma notícia, se observa a posição de contraste entre "nós" e "eles", como se fossem } \\
\text { duas sociedades distintas, regidas por direitos e deveres diferentes. Ou pior: é como } \\
\text { se os Yanomami não tivessem razão alguma em seu pleito, independentemente de } \\
\text { concordarmos ou não com a ocupação. }\end{array}$ \\
\hline $\begin{array}{l}\text { Exemplos/ } \\
\text { Ilustrações }\end{array}$ & $\begin{array}{l}\text { As seguintes ilustrações } \\
\text { encontram-se associadas à } \\
\text { notícia: } \\
\text { 1. AGU em Roraima pede à } \\
\text { Justiça retirada de indios } \\
\text { Yanomami da Sesai } \\
\text { 2. Após 24h, indios } \\
\text { Yanomami seguem }\end{array}$ & $\begin{array}{l}\text { Como afirmamos no capítulo 2, notícias ilustradas têm mais credibilidade e resguardam o } \\
\text { jornal de acusações de racismo. Um exemplo claro disso é o uso de hiperlinks nas notícias } \\
\text { veiculados em meios eletrônicos. É isso que vemos ao lado e discutimos a seguir. } \\
\text { 1. O exemplo mostra que é necessária a ajuda da justiça para retirar os indígenas } \\
\text { do prédio da Sesai } \\
\text { 2. Há uma topicalização do período de ocupação. A chamada é negativa para os } \\
\text { indígenas }\end{array}$ \\
\hline
\end{tabular}




\begin{tabular}{|c|c|c|}
\hline & $\begin{array}{l}\text { ocupando prédio da Sesai } \\
\text { em RR } \\
\text { 3. Armados, indios ocupam } \\
\text { Secretaria de Saúde } \\
\text { Indígena em RR; veja } \\
\text { vídeo }\end{array}$ & $\begin{array}{l}\text { 3. Nessa chamada, os indígenas são mostrados como violentos, já que estão } \\
\text { utilizando armas para ocupar o prédio da Sesai. }\end{array}$ \\
\hline Vaguidade & $\begin{array}{l}\text { Indigenas/ mais de } 50 \\
\text { indígenas/ movimento/ mais } \\
\text { de } 300 \quad \text { comunidades } \\
\text { indígenas/manifestação }\end{array}$ & $\begin{array}{l}\text { Esses dados são imprecisos e geram uma ideia de um número muito grande de } \\
\text { indígenas ocupando o prédio da Sesai. }\end{array}$ \\
\hline Modelos mentais & & $\begin{array}{l}\text { A notícia remete à representação de indígenas que fazem exigência mediante } \\
\text { violência, ocupações e que atrapalham o bom andamento das instituições. Nesse } \\
\text { caso, os indígenas impediam que as pessoas trabalhassem e queriam a exoneração } \\
\text { da coordenadora. }\end{array}$ \\
\hline $\begin{array}{l}\text { Modelo de } \\
\text { dominação de } \\
\text { Thompson }\end{array}$ & $\begin{array}{l}\text { 2.1 Eles invadiram o prédio para } \\
\text { reivindicar a exoneração da } \\
\text { coordenadora do Distrito Especial } \\
\text { de Saúde Indígena Yanomami } \\
\text { (Dsei-Y), Maria de Jesus do } \\
\text { Nascimento } \\
\text { 2.2 Sobre a audiência pública que } \\
\text { teria sido cancelada pelo } \\
\text { secretário da Sesai }\end{array}$ & $\begin{array}{l}\text { 1. Unificação } \\
\text { Simbolização da Unidade: Cria-se, nessa estrutura, uma identidade } \\
\text { indígena única. Mais de } 300 \text { comunidades estão unidas por um mesmo } \\
\text { propósito. É como se os indígenas Yanomami fossem responsáveis por } \\
\text { exprimir a vontade de um único povo, quando, na verdade, sabemos que as } \\
\text { comunidades indígenas brasileiras são as mais diversas possíveis. } \\
\text { 2.Naturalização: Há uma ideia de que a ocupação dos Yanomami já é esperada. } \\
\text { Notamos isso pela escolha da forma verbal continuam ocupando. } \\
\text { 2.1.Nominalização Utiliza-se a forma exoneração para tratar das exigências } \\
\text { dos Yanomamis. Assim, não se faz menção a quem terá que exonerar a } \\
\text { coordenadora, nem é possível cobrar essa iniciativa de alguém. Em nenhum } \\
\text { momento na notícia atribui-se a responsabilidade pela saúde indígena a um agente } \\
\text { em específico. } \\
\text { 2.2 Passivização A voz passiva é utilizada quando a notícia anuncia que a } \\
\text { audiência pública teria sido cancelada. A estratégia foi usada para retirar a } \\
\text { importância de quem a cancelou (o agente). Mais do que isso, o tempo verbal }\end{array}$ \\
\hline
\end{tabular}




\begin{tabular}{|l|l|l|}
\hline & $\begin{array}{l}\text { escolhido coloca em cheque essa informação. Teria mesmo a audiência sido } \\
\text { cancelada? O secretário da Sesai foi jogado para o fim da estrutura, perdendo sua } \\
\text { importância, sendo inclusive, preposicionado, impossibilitando seu retorno à } \\
\text { posição de sujeito. }\end{array}$ \\
\hline
\end{tabular}

\section{Eixo analítico: Comunicação (Notícia 3)}

\section{C.1. Qual(is) o(s) critério(s) de noticiabilidade ressaltado(s)? (Notícia 3)}

\begin{tabular}{|l|l|l|}
\hline $\begin{array}{l}\text { Critérios } \\
\text { de noticiabilidade }\end{array}$ & Enunciados & Análise/síntese \\
\hline Crime/violência & Eles invadiram o prédio & $\begin{array}{l}\text { A invasão de um espaço já anteriormente ocupado por outras pessoas pode } \\
\text { pressupor uso de força, intimidação. Isso, ao mesmo tempo, é crime e violência. }\end{array}$ \\
\hline $\begin{array}{l}\text { Relevância quanto } \\
\text { à evolução futura }\end{array}$ & Permanecem até a exoneração & Não há previsão real para o fim do ato apresentado como violento e criminoso. \\
\hline
\end{tabular}




\section{C.2. Estrutura da notícia (Notícia 3)}

\begin{tabular}{|c|c|c|}
\hline $\begin{array}{l}\text { Estrutura } \\
\text { da notícia }\end{array}$ & Enunciados & Análise/síntese \\
\hline Manchete & $\begin{array}{l}\text { Indígenas Yanomami de Roraima } \\
\text { continuam ocupando prédio da Sesai }\end{array}$ & $\begin{array}{l}\text { A manchete deve responder às seguintes questões: O quê? Quando? Onde? } \\
\text { Como? Por quê? Quem? } \\
\text { Na manchete analisada, porém, não temos a informação do porquê nem como. } \\
\text { Não se deu destaque ao motivo da ocupação, mas apenas que houve uma } \\
\text { ocupação de um prédio público. A temporalidade é vaga, levando a uma primeira } \\
\text { leitura de "tempo longo", como já afirmado anteriormente. }\end{array}$ \\
\hline Lead & $\begin{array}{l}\text { Eles dizem que só saem após } \\
\text { exoneração da coordenadora do } \\
\text { Dsei-Y. Audiência pública teria } \\
\text { sido cancelada; MS ainda não se } \\
\text { pronunciou. }\end{array}$ & $\begin{array}{l}\text { Aqui, já conseguimos identificar um motivo da ocupação, que seria busca de } \\
\text { melhorias na oferta de saúde para o povo Yanomami, mas não é o principal tema } \\
\text { da notícia. O lead dá a entender que está havendo uma oposição de força entre os } \\
\text { Yanomami e o MS. Contudo, ainda não há resposta para a pergunta: Como } \\
\text { ocorreu a ocupação? De forma pacífica? Há uma modalização quanto ao } \\
\text { cancelamento da audiência pública. E também não se informa por que querem a } \\
\text { saída da coordenadora do Dsei-Y. }\end{array}$ \\
\hline $\begin{array}{l}\text { Informações } \\
\text { primárias/iniciais }\end{array}$ & $\begin{array}{l}\text { Ocupação Indígena, exigência da } \\
\text { exoneração/invasãol não } \\
\text { realização de audiência pública } \\
\text { por medo de agressão por parte } \\
\text { dos Yanomami }\end{array}$ & $\begin{array}{l}\text { Trazer como informações iniciais uma ocupação indígena que exige a exoneração } \\
\text { de uma funcionária pública faz com que o leitor já atribua aos indígenas um papel } \\
\text { de desordeiros e intolerantes com relação ao poder público instituído. }\end{array}$ \\
\hline $\begin{array}{l}\text { Informações } \\
\text { secundárias/finais }\end{array}$ & $\begin{array}{l}\text { 1. Alegam que não há remédios e } \\
\text { atendimento médico na área } \\
\text { indígena }\end{array}$ & $\begin{array}{l}\text { O motivo real que levou à ocupação é apresentado somente ao final do primeiro } \\
\text { parágrafo da notícia, após manchete, lead e quatro orações já terem induzido o } \\
\text { leitor a formar uma opinião negativa sobre a ocupação. E, como dissemos antes, } \\
\text { o verbo que introduz o real motivo é semanticamente negativo, tendo em vista } \\
\text { seu uso pragmático ligado ao valor de "possível verdade" ou "verdade que eles } \\
\text { querem nos passar". }\end{array}$ \\
\hline
\end{tabular}




\begin{tabular}{|l|l|l|}
\hline & $\begin{array}{l}\text { 2. Náo estão impedindo } \\
\text { funcionários de trabalhar, o } \\
\text { motivo da ocupação é a falta de } \\
\text { saúde }\end{array}$ & $\begin{array}{l}\text { A informação de que os Yanomami não estão efetivamente impedindo que os } \\
\text { demais funcionários trabalhem (com exceção da coordenadora) é deixada como } \\
\text { informação secundária, que aparece só no final da notícia. Além disso, ela vem } \\
\text { na forma de discurso direto, mostrando que isso é o que afirmam os Yanomami, } \\
\text { podendo ou não ser correspondente à realidade. }\end{array}$ \\
\hline $\begin{array}{l}\text { Caderno/ } \\
\text { Local } \\
\text { da publicação }\end{array}$ & Roraima, publicado em Regiões & $\begin{array}{l}\text { A notícia foi publicada no caderno de Regiões por provavelmente se tratar de um } \\
\text { fato que não é considerado de interesse nacional. }\end{array}$ \\
\hline
\end{tabular}




\subsubsection{Síntese da análise textual da notícia 3}

Há um predomínio da voz ativa no decorrer do texto. A ordem direta só é quebrada, ao longo do texto, na voz passiva, quando se quer jogar para uma posição de menor valor sintático e pragmático o agente que desmarcou a audiência pública. Mais uma vez, os indígenas são colocados em posição de sujeito, exercendo a função de agentes de verbos semanticamente negativos. Outras vezes, eles são topicalizados com a função de fontes da informação, quase sempre com a finalidade de desvalorizar o seu discurso.

Podemos notar ainda que, como dito acima, quando o secretário assume o papel de agente, ele é colocado na posição de agente da passiva, que poderia até mesmo ser removido sem prejuízo sintático do enunciado. No entanto, mais do que ser colocado em posição final, quando o secretário aparece como agente, o texto lança mão do uso de vários adjuntos deslocados para que o agente fique ainda mais distante do verbo, parecendo não haver uma relação direta entre eles (iconicidade).

O uso sistemático de metonímias faz com que o leitor acredite que os indígenas estavam presentes em grande número no prédio e que estavam ocupando o prédio inteiro.

Há uma recorrente escolha por verbos semanticamente negativos quando se trata das ações indígenas. Há também a opção por citar diretamente o discurso indígena, porém, ele é usado de forma estratégica para contradizer as informações apresentadas pelos fatos e questionar a índole da comunidade indígena. Há também o uso da unificação (THOMPSON, 1995), sugerindo que as comunidades indígenas estão unidas contra o não-indígena e que são uma ameaça ao bem-estar social e à ordem. Além disso, quando o governo é trazido, suas ações são modalizadas ou nominalizadas como em "teria sido cancelada" ou em "exoneração". O discurso é todo construído em torno de informações duvidosas fornecidas pelos indígenas, ora em discurso direto, ora em discurso indireto. Martino (2013, p. 39) ressalta que

\footnotetext{
Quando o repórter dá espaço para outras vozes contarem a história, ele está igualmente se protegendo de qualquer crítica sobre uma possível distorção da notícia - foi a fonte quem disse, não o jornalista, e portanto não há culpa nem responsabilidade se a informação foi alterada. Não é necessário que o profissional diga explicitamente o que ele pensa: é mais fácil e seguro dizer isso colocando as palavras na boca da fonte. (...) É o que Gaye Tuchman define como "ritual estratégico" que diminui a responsabilidade do jornalista, de um lado, e lhe dá permissão mínima para mudar o que for necessário sob a capa da objetividade, criada pela contínua menção às fontes ou aos fatos em si.
}

A ocupação torna-se motivo por se tratar de um prédio público; portanto, interessa à população que haja a reintegração de posse. A manchete e o lead não trazem as informações 
que são esperadas. Ao longo do texto, essas informações vão sendo preenchidas por meio de invited inferecing ( TRAUGOTT \& DASHER, 2005). O foco da notícia recaí sobre a ocupação e não sobre as reinvindicações indígenas, que são colocadas como informações secundárias; pouco se fala sobre a situação da saúde indígena, sobre a falta de medicamentos e de profissionais. Ao contrário, a motivação da ocupação aparece rapidamente numa fala indígena. O nível de descrição (cf. VAN DIJK 2003, p.46), nesse texto, é baixo no que tange à comunidade indígena, não sabemos o espaço real que eles ocupam, ficamos com a impressão de que é o prédio inteiro. Não há muitos detalhes sobre os problemas que a comunidade enfrenta em relação à saúde. Ao contrário, o foco recai sobre as consequências da ocupação: pede-se a exoneração de uma servidora, os funcionários estão sendo impedidos de trabalhar e o prédio fica por um longo tempo ocupado. As estruturas (coerência local) contribuem para essa formação de causa e consequência: a ocupação impede que funcionários cumpram suas tarefas e trabalhem. No geral, há uma ideia de que os indígenas estão atrapalhando o trabalho alheio, impedindo que funcionários entrem e exigindo a demissão de outra. 


\subsection{Análise Textual 4 - Notícia 4}

\section{Notícia 4}

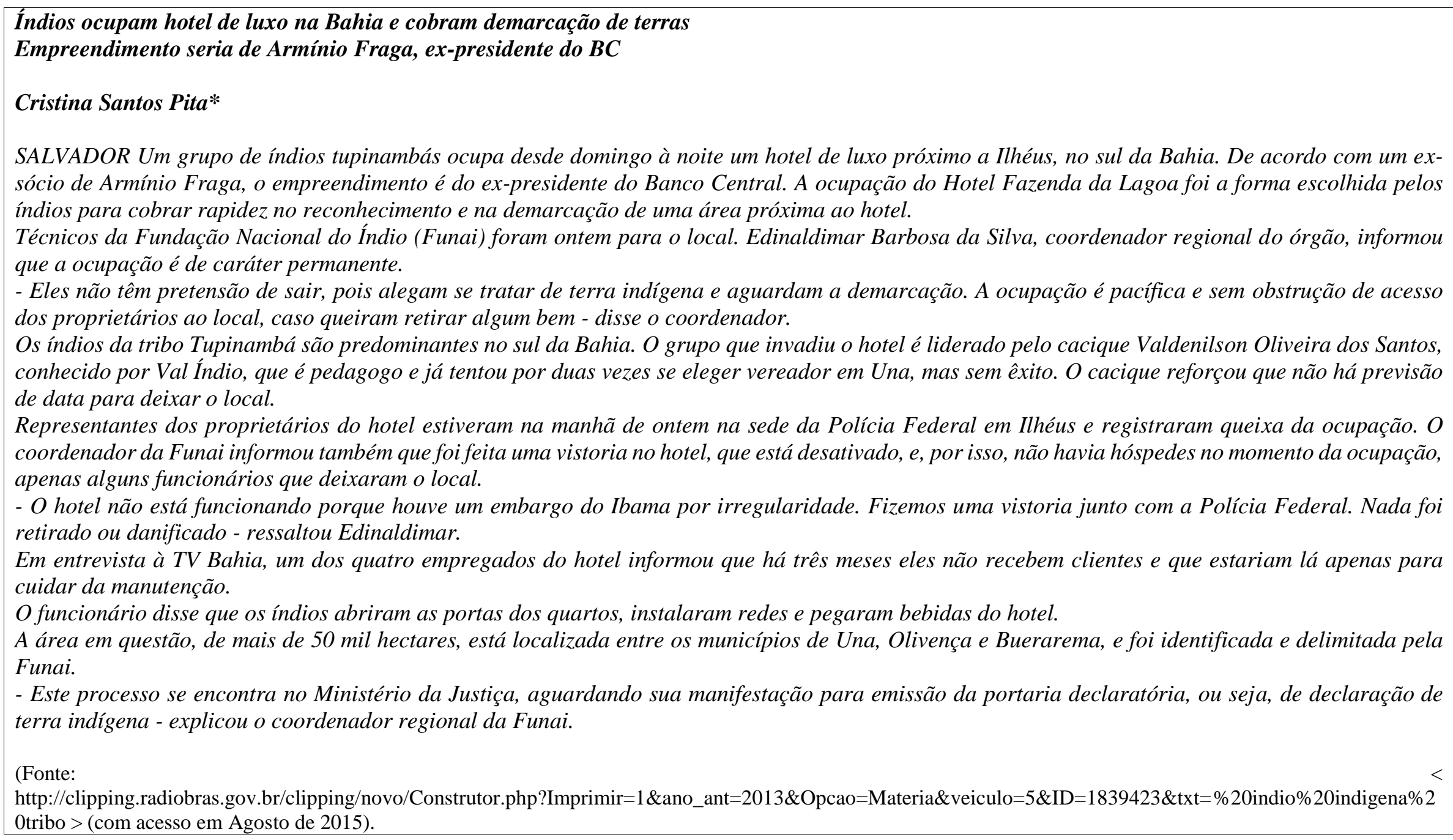




\section{A - Eixo analítico: Linguística Cognitivo-Funcional (Linguística Centrada no Uso) (Notícia 4)}

\section{A.1 Voz (stricto sensu e lato sensu)/ Valência verbal (Notícia 4)}

\begin{tabular}{|c|c|c|c|c|}
\hline Enunciados & Voz /ordem & $\begin{array}{l}\text { Valência } \\
\text { Sintática }\end{array}$ & $\begin{array}{l}\text { Valência } \\
\text { Semântica }\end{array}$ & Análise/Síntese \\
\hline $\begin{array}{l}\text { 1[Índios ocupam hotel de } \\
\text { luxo na Bahia] 2[e cobram } \\
\text { demarcação de terras] }\end{array}$ & $\begin{array}{l}\text { Oração } 1 \text { e } 2: \text { voz } \\
\text { ativa; } \quad \text { ordem } \\
\text { direta }(\mathrm{SVO}) .\end{array}$ & 2 & 2 & $\begin{array}{l}\text { A voz ativa, nesse caso, tem um sujeito prototípico: humano, } \\
\text { com volição, que age sobre um objeto inanimado, paciente; } \\
\text { este sofre uma mudança de estado. }\end{array}$ \\
\hline $\begin{array}{l}\text { Empreendimento seria de } \\
\text { Armínio Fraga, ex- } \\
\text { presidente do } B C\end{array}$ & $\begin{array}{l}\text { Voz ativa; ordem } \\
\text { direta (SVO). }\end{array}$ & 2 & 2 & $\begin{array}{l}\text { Aqui, faz-se o uso de uma voz ativa, porém, o sujeito não é } \\
\text { prototípico, como veremos em A.2. Pode-se imaginar que } \\
\text { houve uma tentativa de tirar Armínio Fraga da posição } \\
\text { prototípica de sujeito. }\end{array}$ \\
\hline $\begin{array}{l}\text { Um grupo de índios } \\
\text { tupinambás ocupa desde } \\
\text { domingo à noite um hotel de } \\
\text { luxo próximo a Ilhéus, no sul } \\
\text { da Bahia }\end{array}$ & $\begin{array}{l}\text { Voz ativa; ordem } \\
\text { direta (SVO). }\end{array}$ & 2 & 2 & $\begin{array}{l}\text { Assim como na manchete, há nesse enunciado o uso da voz } \\
\text { ativa, utilizando um verbo que demanda um sujeito com alto } \\
\text { grau de volição e controle. }\end{array}$ \\
\hline $\begin{array}{l}\text { 1[O hotel não está } \\
\text { funcionando] 2[porque } \\
\text { houve um embargo do } \\
\text { Ibama por irregularidade.] }\end{array}$ & $\begin{array}{l}1 . \\
\text { voz ativa; ordem } \\
\text { direta (SV); } \\
2 . \\
\text { Voz ativa; ordem } \\
\text { indireta (VS). }\end{array}$ & $\begin{array}{l}\text { Ambas } \\
\text { orações: } \\
1\end{array}$ & $\begin{array}{l}\text { Ambas } \\
\text { orações: } \\
1\end{array}$ & $\begin{array}{l}\text { Há uso da voz ativa, porém com um sujeito atípico. As duas } \\
\text { orações são intransitivas ( } O \text { hotel não está funcionando e } \\
\text { houve embargo do Ibama por irregularidade). }\end{array}$ \\
\hline
\end{tabular}




\section{A.2. Relações gramaticais/ Papéis Semânticos/ Papéis Pragmáticos (Notícia 4)}

\begin{tabular}{|c|c|c|c|c|c|}
\hline Enunciados & $\begin{array}{l}\text { Argumentos/ } \\
\text { Adjuntos }\end{array}$ & $\begin{array}{c}\text { RG ou } \\
\text { Adjuntos }\end{array}$ & $\begin{array}{c}\text { Papel } \\
\text { Semântico }\end{array}$ & $\begin{array}{c}\text { Papel } \\
\text { Pragmático }\end{array}$ & Análise/Síntese \\
\hline $\begin{array}{l}\text { 1[Índios ocupam hotel } \\
\text { de luxo na Bahia] 2[e } \\
\text { cobram demarcação de } \\
\text { terras] }\end{array}$ & $\begin{array}{l}\text { Oração 1: } \\
\text { Arg1: índios } \\
\text { Arg2: hotel de } \\
\text { luxo } \\
\text { Adjunto: na } \\
\text { Bahia } \\
\text { Oração 2: } \\
\text { Arg1: (índios) } \\
\text { Arg2: } \\
\text { demarcação de } \\
\text { terras }\end{array}$ & $\begin{array}{l}\text { Oração 1: } \\
\text { Arg1: Sujeito } \\
\text { Arg2: Objeto } \\
\text { direto } \\
\text { Adjunto: } \\
\text { adverbial } \\
\text { Oração 2: } \\
\text { Arg1: sujeito } \\
\text { Arg2: objeto } \\
\text { direto }\end{array}$ & $\begin{array}{l}\text { Oração 1: } \\
\text { Arg1: Agente } \\
\text { Arg2: Paciente } \\
\text { Adj: Lugar } \\
\text { Oração 2: } \\
\text { Arg1: agente } \\
\text { Arg2: Tema }\end{array}$ & $\begin{array}{l}\text { Oração 1: } \\
\text { Arg1: Tópico } \\
\text { Arg2: Foco } \\
\text { Oração 2: } \\
\text { Arg1: Tópico } \\
\text { Arg2: Foco }\end{array}$ & $\begin{array}{l}\text { Na oração 1, o alinhamento é prototípico, o } \\
\text { sujeito é agente e tópico, enquanto o objeto } \\
\text { é paciente e foco. Interessante notar, porém, } \\
\text { o uso da nominalização demarcação. Ela } \\
\text { permite omitir quem é responsável pelo } \\
\text { processo. }\end{array}$ \\
\hline $\begin{array}{l}\text { Empreendimento seria } \\
\text { de Armínio Fraga, ex- } \\
\text { presidente do } B C\end{array}$ & $\begin{array}{l}\text { Arg1: } \\
\text { Empreendimen } \\
\text { to } \\
\text { Arg2: de } \\
\text { Arminio } \\
\text { Fraga }\end{array}$ & $\begin{array}{l}\text { Arg1: Sujeito } \\
\text { Arg2: Objeto } \\
\text { indireto }\end{array}$ & $\begin{array}{l}\text { Arg1: Tema } \\
\text { Arg2: } \\
\text { Possuidor }\end{array}$ & $\begin{array}{l}\text { Arg1: Tópico } \\
\text { Arg2: Foco }\end{array}$ & $\begin{array}{l}\text { O alinhamento não é prototípico. Temos um } \\
\text { sujeito que não é humano, não tem volição } \\
\text { e não provoca mudança de estado no objeto. } \\
\text { Além disso, o sujeito é tema. O possuidor } \\
\text { vem preposicionado, perdendo força } \\
\text { sintática. Provavelmente, isso foi feito para } \\
\text { que o papel pragmático de Armínio Fraga } \\
\text { perdesse a importância, e ele não pudesse } \\
\text { ser retomado como sujeito sintático. }\end{array}$ \\
\hline $\begin{array}{l}\text { Um grupo de índios } \\
\text { tupinambás ocupa desde } \\
\text { domingo à noite um hotel } \\
\text { de luxo próximo a Ilhéus, } \\
\text { no sul da Bahia }\end{array}$ & $\begin{array}{l}\text { Arg1: Um grupo } \\
\text { de índios } \\
\text { tupinambá } \\
\text { Arg2: um hotel } \\
\text { de luxo }\end{array}$ & $\begin{array}{l}\text { Arg1: Sujeito } \\
\text { Arg2: Objeto } \\
\text { direto }\end{array}$ & Arg2: Paciente & Arg2: Foco & $\begin{array}{l}\text { O alinhamento é prototípico, temos um } \\
\text { sujeito agente, com alto grau de volição e } \\
\text { controle sobre um paciente inanimado, sem } \\
\text { volição, sem controle e que sofre uma } \\
\text { mudança de estado provocada pelo sujeito. }\end{array}$ \\
\hline
\end{tabular}




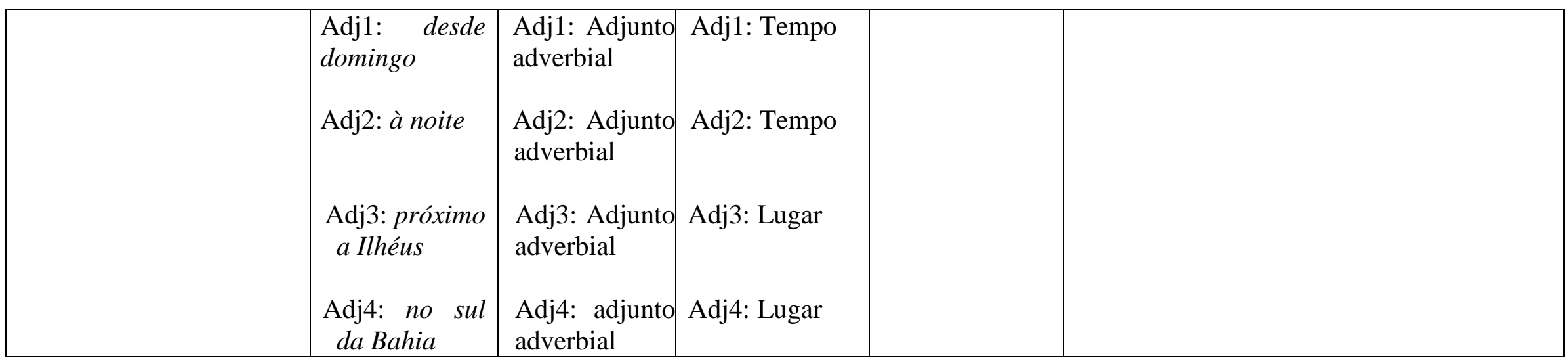

\section{A.3. Metáforas e metonímias (Notícia 4)}

\begin{tabular}{|c|c|c|}
\hline $\begin{array}{l}\text { Metáfora } \\
\text { ou } \\
\text { Metonímia }\end{array}$ & Enunciados & Análise/Síntese \\
\hline Metáfora & $\begin{array}{l}\text { Um grupo de índios tupinambás ocupa desde } \\
\text { domingo à noite um hotel de luxo próximo a Ilhéus, } \\
\text { no sul da Bahia. + Eles não têm pretensão de sair, } \\
\text { pois alegam se tratar de terra indígena e aguardam } \\
\text { a demarcação. }+ \text { O funcionário disse que os índios } \\
\text { abriram as portas dos quartos, instalaram redes e } \\
\text { pegaram bebidas do hotel. }\end{array}$ & $\begin{array}{l}\text { CRIME + BADERNA + CAOS. Todos esses enunciados nos levam a } \\
\text { crer que os Tupinambá estão cometendo um crime ao invadir uma } \\
\text { propriedade privada. O tom de baderna é dado pela informação de que } \\
\text { eles arrombaram quartos, montaram suas redes, em alusão tipificada e } \\
\text { massificada dos índios brasileiros, reforçando o senso comum que alega } \\
\text { que os indígenas brasileiros têm problemas com álcool e são } \\
\text { preguiçosos. }\end{array}$ \\
\hline Metonímia & $\begin{array}{l}\text { Índios ocupam hotel de luxo na Bahia e cobram } \\
\text { demarcação de terras }\end{array}$ & $\begin{array}{l}\text { Há uma massificação dos Tupinambás. Não sabemos se estamos } \\
\text { tratando de uma comunidade indígena ou de várias. Além disso, o termo } \\
\text { "índios" faz parecer que há muitos indígenas no local. }\end{array}$ \\
\hline
\end{tabular}




\section{A.4 . Iconicidade Diagramática (Notícia 4)}

\begin{tabular}{|c|l|l|}
\hline \multicolumn{1}{|c|}{ Enunciados } & Tipificação & \multicolumn{1}{c|}{ Análise/Síntese } \\
\hline $\begin{array}{l}\text { Um grupo de índios tupinambás } \\
\text { ocupa desde domingo à noite um } \\
\text { hotel de luxo próximo a Ilhéus, no } \\
\text { sul da Bahia }\end{array}$ & $\begin{array}{l}\text { Quantidade, } \\
\text { Complexidade }\end{array}$ & $\begin{array}{l}\text { O sujeito é extenso, levando a crer que se trata de um grande número de } \\
\text { Tupinambás. Em momento algum, foi citada a quantidade exata ou aproximada, } \\
\text { criando no imaginário do leitor a ideia de que são muitos. }\end{array}$ \\
\hline
\end{tabular}

\section{A.5 Frames (Notícia 4)}

\begin{tabular}{|c|c|c|}
\hline Enunciados & Frames & Análise/Síntese \\
\hline $\begin{array}{l}\text { O funcionário disse que os índios } \\
\text { abriram as portas dos quartos, } \\
\text { instalaram redes e pegaram } \\
\text { bebidas do hotel. }\end{array}$ & $\begin{array}{l}\text { ALCOOLISMO } \\
\text { INDÍGENAS } \\
\text { PREGUIÇOSO }\end{array}$ & $\begin{array}{l}\text { O enunciado, como já dito em A.3, aciona o frame que está enraizado num senso } \\
\text { comum de que todos os indígenas têm problemas com o álcool. E esse é um } \\
\text { problema que normalmente se relaciona com a violência. Além disso, um outro } \\
\text { frame acionado pela frase "instalaram redes" evoca a ideia do índio preguiçoso, } \\
\text { que passa o dia inteiro deitado em uma rede. }\end{array}$ \\
\hline $\begin{array}{l}\text { O grupo que invadiu o hotel é } \\
\text { liderado pelor cacique } \\
\text { Valdenilson Oliveira dos Santos, } \\
\text { conhecido por Val Indio, que é } \\
\text { pedagogo e já tentou por duas } \\
\text { vezes se eleger vereador em Una, } \\
\text { mas sem exito. }\end{array}$ & $\begin{array}{l}\text { INVASÃO INDÍGENA } \\
X \\
\text { EDUCAÇÃO } \quad \text { SUPERIOR } \\
\text { INDÍGENA } \\
X \\
\text { ÍNDIO NA POLÍTICA }\end{array}$ & $\begin{array}{l}\text { Esse enunciado aciona o frame "índios são invasores". Porém, aciona } \\
\text { também a educação superior na área da pedagogia, o que soa como } \\
\text { contraditório. Esse enunciado parece sugerir que a educação superior } \\
\text { não foi suficiente para "civilizar" o indígena. Por fim, ainda há } \\
\text { referência ao índio na política, o que também faz crer que a ocupação } \\
\text { do hotel seria um ato politiqueiro praticado pelo líder do grupo. }\end{array}$ \\
\hline $\begin{array}{l}\text { informou que a ocupação é de } \\
\text { caráter permanente }\end{array}$ & CONTINUIDADE/CONSTÂNCIA & $\begin{array}{l}\text { Não se consegue enxergar um fim para a ação considerada criminosa dos } \\
\text { Tupinambás, o que é inverídico. }\end{array}$ \\
\hline
\end{tabular}


B. Eixo analítico: Discurso e Ideologia (Notícia 4)

\begin{tabular}{|c|c|c|}
\hline Construtos & Enunciados & Análise/síntese \\
\hline Escolhas lexicais & $\begin{array}{l}\text { A ocupação do Hotel (...) } \\
\text { foi a forma escolhida pelos } \\
\text { indigenas (...) }\end{array}$ & $\begin{array}{l}\text { A opção por essa estrutura quer mostrar que os indígenas dispunham de outras } \\
\text { alternativas que não a ocupação do hotel. Confere volição, responsabilidade e } \\
\text { controle sobre as ações praticadas por eles, portanto. }\end{array}$ \\
\hline Topoi & $\begin{array}{l}\text { Índios ocupam hotel de } \\
\text { luxo na Bahia e cobram } \\
\text { demarcação de terras }\end{array}$ & $\begin{array}{l}\text { Apesar de a manchete trazer a ocupação indígena e suas motivações, o texto em } \\
\text { sua maior parte trata apenas da ocupação, limitando-se a fazer breves } \\
\text { considerações sobre as motivações indígenas e discutir a questão de demarcação } \\
\text { do território. O senso comum é: índios são invasores de propriedades privadas. }\end{array}$ \\
\hline \multicolumn{3}{|l|}{ Modalização } \\
\hline Evidencialidade & $\begin{array}{l}\text { 1. Edinaldimar Barbosa da } \\
\text { Silva, coordenador regional } \\
\text { do órgão [FUNAI], informou } \\
\text { que a ocupação é de caráter } \\
\text { permanente } \\
\text { 2. (...) disse o coordenador } \\
\text { 2. O cacique reforçou que } \\
\text { não há previsão de data } \\
\text { para deixar o local. } \\
\text { 3. O coordenador da Funai } \\
\text { informou também que (...) } \\
\text { 4. (...) ressaltou Edinaldimar } \\
\text { 5. Em entrevista à TV Bahia, } \\
\text { um dos empregados do } \\
\text { hotel informou que (...) } \\
\text { 6. O funcionário disse que os } \\
\text { indios (...); } \\
\text { 7. (...) explicou } \\
\text { coordenador regional da } \\
\text { Funai }\end{array}$ & $\begin{array}{l}\text { Identificam-se três fontes para as informações levadas ao público pela notícia: a) o } \\
\text { coordenador regional da Funai, Edinaldimar; b) o cacique Tupinambá; c) um } \\
\text { empregado do hotel. Claramente, a fonte primária do jornal foi o coordenador } \\
\text { regional, que aparece em cinco dos oito enunciados }(1,2,4,5 \text { e } 8) \text { em que a fonte } \\
\text { da informação é claramente dada. O cacique, representante dos Tupinambás, teve } \\
\text { a voz revelada uma única vez no texto e de maneira indireta, ao contrário do } \\
\text { coordenador cuja voz aparece de maneira direta três vezes. Até mesmo um } \\
\text { funcionário do hotel teve sua voz apresentada mais vezes que a voz da liderança } \\
\text { Tupinambá (duas vezes). É evidente a desigualdade na distribuição dos turnos de } \\
\text { fala. Aos Tupinambás, não é dada oportunidade real de explicar, discutir, } \\
\text { argumentar. Sobram-lhes preconceitos. }\end{array}$ \\
\hline
\end{tabular}




\begin{tabular}{|c|c|c|}
\hline Tópico & $\begin{array}{l}\text { Índios invadem propriedade } \\
\text { privada }\end{array}$ & $\begin{array}{l}\text { Novamente, o tema central de uma notícia sobre índios brasileiros é a invasão } \\
\text { praticada por eles contra um bem privado. Parace ser o tópico preferido da } \\
\text { imprensa nacional ao lado de notícias que expoem os índios do Brasil como } \\
\text { violentos e contraventores. }\end{array}$ \\
\hline Contexto & $\begin{array}{l}\text { Índios ocupam hotel de luxo } \\
\text { na Bahia e cobram } \\
\text { demarcação de terras }\end{array}$ & $\begin{array}{l}\text { A manchete traz parte do contexto em que nos encontramos no tocante à causa } \\
\text { indígena no Brasil. Há uma luta pela demarcação de terras, que não ocorre a } \\
\text { contento. Essa inércia dos últimos anos tem levado a ocupações e respostas duras } \\
\text { dos povos indígenas. Não há uma reflexão séria sobre o assunto na mídia impressa, } \\
\text { digital, radiofônica ou televisiva. Há apenas uma exposição negativa da imagem } \\
\text { dos povos indígenas brasileiros. }\end{array}$ \\
\hline $\begin{array}{l}\text { Racismo do dia a } \\
\text { dia }\end{array}$ & $\begin{array}{l}\text { O funcionário disse que os } \\
\text { indios abriram as portas dos } \\
\text { quartos, instalaram redes e } \\
\text { pegaram bebidas do hotel. }\end{array}$ & $\begin{array}{l}\text { O fato de que os Tupinambás estão pegando bebidas, provavelmente alcoólicas, já } \\
\text { não causa espanto, pois está no imaginário coletivo a imagem de um indígena que } \\
\text { tem problemas com a bebida. O indígena invasor, violente e viciado em álcool é } \\
\text { apresentado com frequência na mídia. }\end{array}$ \\
\hline $\begin{array}{l}\text { Implicações/ } \\
\text { Pressuposições }\end{array}$ & $\begin{array}{l}\text { 1. A ocupação do Hotel (...) } \\
\text { foi a forma escolhida pelos } \\
\text { indígenas (...) } \\
\text { 2. Empreendimento seria de } \\
\text { Armínio Fraga, ex-presidente } \\
\text { do BC } \\
\\
\text { 3. O grupo que invadiu o hotel } \\
\text { é liderado pelo cacique } \\
\text { Valdenilson Oliveira dos } \\
\text { Santos, conhecido por Val } \\
\text { Índio, que é pedagogo e já } \\
\text { tentou por duas vezes se } \\
\text { eleger vereador em Una, } \\
\text { mas sem êxito }\end{array}$ & $\begin{array}{l}\text { 1. Fica implícito que havia outras opções legais para resolver o problema, mas que } \\
\text { os Tupinambá escolheram a forma ilegal. } \\
\text { 2. O uso do futuro do pretérito mostra que a posse sobre a propriedade é apenas } \\
\text { uma suposição. Pode ser que Armínio Fraga não seja o dono. Essa informação } \\
\text { sugere um grau maior de erro à ocupação, dando a entender que uma figura } \\
\text { importante, um ex-presidente do Banco Central, estava sendo incomodado por } \\
\text { índios... } \\
\text { 3. Esse enunciado sugera que, apesar da educação superior, o cacique não teve } \\
\text { competência suficiente para se eleger, e agora, liderando uma ocupação, mostra } \\
\text { que a população fez a escolha certa ao não votar nele. Essas são inferências } \\
\text { possíveis a partir da reunião dessas informações nesse período. E ainda se } \\
\text { poderia pensar que a decisão de ocupar o hotel seria uma estratégia política para } \\
\text { angariar votos dos eleitores indígenas. }\end{array}$ \\
\hline
\end{tabular}




\begin{tabular}{|c|c|c|}
\hline $\begin{array}{l}\text { Sinônimos/ } \\
\text { Paráfrases }\end{array}$ & $\begin{array}{l}\text { 1. índios; } \\
\text { 2. indígenas; } \\
\text { 3. indios tupinambás } \\
\text { 4. indios da tribo } \\
\quad \text { Tupinambá; } \\
\text { 5. grupo; } \\
\text { 6. ocupação; } \\
\text { 7. hotel de luxo; } \\
\text { 8. empreendimento; } \\
\text { 9. hotel; } \\
\text { 10. Hotel Fazenda da Lagoa. }\end{array}$ & $\begin{array}{l}\text { De } 1 \text { até } 6 \text {, temos os sinônimos escolhidos para fazer referência aos } \\
\text { Tupinambás, enquanto que de } 7 \text { a } 10 \text {, há os sinônimos para o hotel. Nota-se } \\
\text { que, para falar dos Tupinambás, utiliza-se como sinônimo preferido a palavra } \\
\text { índios, termo genérico e massificante; também se utiliza grupo ou ocupação de } \\
\text { maneira pejorativa; enquanto isso, para falar do hotel, utilizam-se palavras que } \\
\text { destacam seu caráter luxuoso, empreendedor, muito embora o hotel esteja } \\
\text { fechado e embargado, informação que só é dada quase ao final da notícia. }\end{array}$ \\
\hline Disclaimers & $\begin{array}{l}\text { A notícia como um todo é um } \\
\text { disclaimer. }\end{array}$ & $\begin{array}{l}\text { Expor índios como invasores, consumidores de álcool e preguiçosos que só querem } \\
\text { ficar em redes é inverter completamente a história dos fatos em nosso país. A } \\
\text { menção ao tamanho da área ("mais de } 50 \text { mil hectares”) e sua distribuição em três } \\
\text { municípios, também leva a crer que não é uma demanda justa, o que é uma nova } \\
\text { inversão de valores. }\end{array}$ \\
\hline Coerência local & $\begin{array}{l}\text { Índios ocupam hotel de luxo } \\
\text { na Bahia } \Rightarrow \text { A ocupação do } \\
\text { Hotel Fazenda da Lagoa foi a } \\
\text { forma escolhida pelos índios } \\
\Rightarrow \text { a ocupação é de caráter } \\
\text { permanente } \Rightarrow \text { Eles não têm } \\
\text { pretensão de sair } \Rightarrow \text { O } \\
\text { cacique reforçou que não há } \\
\text { previsão de data para deixar } \\
\text { o local } \Rightarrow \text { os indios abriram } \\
\text { as portas dos quartos } \Rightarrow \\
\text { instalaram redes } \Rightarrow e \\
\text { pegaram bebidas do hotel. }\end{array}$ & $\begin{array}{l}\text { A sequência apresentada quer mostrar que os indígenas tinham pleno controle } \\
\text { sobre suas ações. Além disso, a maneira como o texto foi construído leva o leitor } \\
\text { a crer que não haverá uma saída dos indígenas em um futuro próximo. E aí se } \\
\text { constrói, uma vez mais, a ideia de que índios são preguiçosos, usurpadores do bem } \\
\text { alheio e bêbados. }\end{array}$ \\
\hline
\end{tabular}




\begin{tabular}{|c|c|c|}
\hline Contraste & $\begin{array}{c}\text { Armínio Fraga, o } \\
\text { empreendimento é do ex- } \\
\text { presidente do Banco Central. } \\
\text { X } \\
\text { cacique Valdenilson Oliveira } \\
\text { dos Santos, conhecido por } \\
\text { Val Índio, que é pedagogo e } \\
\text { já tentou por duas vezes se } \\
\text { eleger vereador em Una, mas } \\
\text { sem êxito }\end{array}$ & $\begin{array}{l}\text { Enquanto o dono do hotel é representado como uma pessoa bem-sucedida, o } \\
\text { cacique, autoridade entre os indígenas, é representado como um pedagogo que } \\
\text { tentou uma carreira política, mas fracassou. }\end{array}$ \\
\hline $\begin{array}{l}\text { Exemplos/ } \\
\text { Ilustrações }\end{array}$ & $\begin{array}{l}\text { Não havia hiperlinks nessa } \\
\text { notícia. }\end{array}$ & \\
\hline Vaguidade & 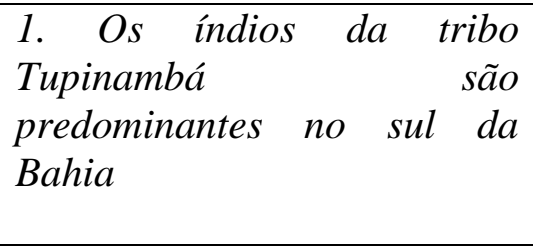 & $\begin{array}{l}\text { Essa informação foi dada no meio do texto de maneira vaga, para que o leitor faça } \\
\text { as inferências sugeridas. O que significa ter uma concentração maior de indígenas } \\
\text { no sul da Bahia? Mais hotéis serão ocupados? Existem outros tupinambás em } \\
\text { outros Estados? Seriam eles um tipo de animal ou vegetal predominante em dada } \\
\text { região? Essa construção é tipicamente usada para esse fim. }\end{array}$ \\
\hline Modelos mentais & & $\begin{array}{l}\text { Cf. Frames (seção A.5) e toda discussão sobre estereótipos; há no Brasil o } \\
\text { estereótipo de indígena selvagem, que dorme apenas em redes e bebe muito. O } \\
\text { texto se utiliza desse estereótipo para ajudar na culpabilização dos indígenas. }\end{array}$ \\
\hline $\begin{array}{l}\text { Modelo de } \\
\text { dominação de } \\
\text { Thompson }\end{array}$ & $\begin{array}{l}\text { 1. Índios ocupam hotel de } \\
\text { luxo na Bahia e cobram } \\
\text { demarcação de terras } \\
\text { 2. O cacique reforçou que não há } \\
\text { previsão de data para deixar o } \\
\text { local. }\end{array}$ & $\begin{array}{l}\text { 1. Unificação: O termo índios massifica, faz com que a leitura seja a de que todos } \\
\text { os indígenas são uma ameaça ao bem-estar social. } \\
\text { 2. Eternização: Há uma tentativa de tornar a ocupação eterna. A informação, tendo } \\
\text { sido dada pelo próprio cacique, indica que os indígenas não deixarão o local tão } \\
\text { cedo. Já havia sido mencionado que não havia uma data determinada para os } \\
\text { indígenas deixarem o local, mas opta-se por reafirmar que o fim não está próximo. }\end{array}$ \\
\hline
\end{tabular}




\section{Eixo analítico: Comunicação (Notícia 4)}

\section{C.1. Qual(is) o(s) critério(s) de noticiabilidade ressaltado(s)? (Notícia 4)}

\begin{tabular}{|l|l|l|}
\hline $\begin{array}{l}\text { Critérios } \\
\text { de noticiabilidade }\end{array}$ & Enunciados & Análise/síntese \\
\hline $\begin{array}{l}\text { Interesse } \\
\text { pessoal/econômico }\end{array}$ & $\begin{array}{l}\text { Índios ocupam hotel de luxo na } \\
\text { Bahia e cobram demarcação de } \\
\text { terras }\end{array}$ & $\begin{array}{l}\text { Há um interesse pessoal, pois uma propriedade privada está sendo invadida. O } \\
\text { mesmo pode acontecer a outros empreendimentos do mesmo ramo. O hotel é de } \\
\text { luxo, o que parece ferir enormemente interesses econômicos no estado. }\end{array}$ \\
\hline Crime/violência & $\begin{array}{l}\text { Índios ocupam hotel de luxo na } \\
\text { Bahia e cobram demarcação de } \\
\text { terras }\end{array}$ & $\begin{array}{l}\text { A ocupação de uma propriedade privada se configura como crime e, por isso, ela } \\
\text { deve ser notíciada. }\end{array}$ \\
\hline $\begin{array}{l}\text { Proeminência do } \\
\text { indivíduo } \\
\text { sociedade }\end{array}$ & $\begin{array}{l}\text { Empreendimento seria de Armínio } \\
\text { Fraga, ex-presidente do BC }\end{array}$ & $\begin{array}{l}\text { Armínio Fraga é um indivíduo que ocupou um alto posto em um governo passado } \\
\text { e, agora, sofre uma injustiça: sua propriedade está sendo invadida. A notícia } \\
\text { sugere que, se isso está acontecendo com pessoas importantes, outros podem ser } \\
\text { afetados, inclusive pequenos proprietários. }\end{array}$ \\
\hline
\end{tabular}




\section{C.2. Estrutura da notícia (Notícia 4)}

\begin{tabular}{|c|c|c|}
\hline $\begin{array}{l}\text { Estrutura } \\
\text { da notícia }\end{array}$ & Enunciados & Análise/síntese \\
\hline Manchete & $\begin{array}{l}\text { Índios ocupam hotel de luxo na } \\
\text { Bahia e cobram demarcação de } \\
\text { terras }\end{array}$ & $\begin{array}{l}\text { A manchete responde às principais perguntas: Que, Quem, Onde e Por que. } \\
\text { Apesar de trazer a razão que levou à ocupação do hotel, ao longo da notícia pouco } \\
\text { se fala sobre isso. A manchete tem duas partes. Na primeira, se informa a } \\
\text { ocupação; na segunda, a sua razão. Ao longo do texto, a razão não é, } \\
\text { definitivamente, bem desenvolvida, ao contrário do tópico primeiramente } \\
\text { ressaltado. }\end{array}$ \\
\hline Lead & $\begin{array}{l}\text { Empreendimento seria de Armínio } \\
\text { Fraga, ex-presidente do } B C\end{array}$ & $\begin{array}{l}\text { O lead sugere que ainda há dúvidas sobre a posse do hotel, mas pode ser que ele } \\
\text { seja de alguém que tem uma proeminência social e financeira na sociedade. O } \\
\text { nome de Armínio Fraga traz força para a notícia e evoca os subentendidos } \\
\text { anteriormente já abordados em nossa análise. }\end{array}$ \\
\hline $\begin{array}{l}\text { Informações } \\
\text { primárias/iniciais }\end{array}$ & $\begin{array}{l}\text { Um grupo de índios tupinambás } \\
\text { ocupa desde domingo à noite um } \\
\text { hotel de luxo próximo a Ilhéus. } \\
\text { De acordo com um ex-sócio de } \\
\text { Armínio Fraga,o empreendimento } \\
\text { é do ex-presidente do Banco } \\
\text { Central. } \\
\text { A ocupação do Hotel Fazenda foi } \\
\text { a forma escolhida pelos índios } \\
\text { para cobrar rapidez no } \\
\text { reconhecimento e na demarcação } \\
\text { de uma área próxima ao hotel. }\end{array}$ & $\begin{array}{l}\text { As informações primárias tratam fortemente da ocupação indígena, do suposto } \\
\text { dono do hotel e ressaltam que a ocupação foi uma escolha dos Tupinambás na } \\
\text { tentativa de pressionar o Estado a demarcar terras indígenas. Como explica } \\
\text { Kleiman (2003), esse sentido primário é o que vai nortear toda a leitura do resto } \\
\text { do texto. A demarcação ficará em segundo plano e só será parcialmente explicada } \\
\text { no final do texto. }\end{array}$ \\
\hline
\end{tabular}




\begin{tabular}{|c|c|c|}
\hline $\begin{array}{l}\text { Informações } \\
\text { secundárias/finais }\end{array}$ & $\begin{array}{l}\text { A área em questão, de mais de } 50 \\
\text { mil hectares, está localizada entre } \\
\text { os municípios de Una, Olivença e } \\
\text { Buerarema, e foi identificada e } \\
\text { delimitada pela Funai. } \\
\text { - Este processo se encontra no } \\
\text { Ministério da Justiça, } \\
\text { aguardando sua manifestação } \\
\text { para emissão da portaria } \\
\text { declaratória, ou seja, de } \\
\text { declaração de terra indígena - } \\
\text { explicou o coordenador regional } \\
\text { da Funai. }\end{array}$ & $\begin{array}{l}\text { Como informações secundárias e finais, portanto menos importantes, temos a } \\
\text { questão da demarcação das terras indígenas. É somente no final da notícia que se } \\
\text { apresenta brevemente a motivação indígena, mas, ainda sim, sem grandes } \\
\text { explicações ou cobranças por atitudes. Ao contrário, é sugerido que a área é muito } \\
\text { extensa para a quantidade de índios, atravessando três municípios. }\end{array}$ \\
\hline $\begin{array}{l}\text { Caderno/ } \\
\text { Local } \\
\text { da publicação }\end{array}$ & O País & $\begin{array}{l}\text { A notícia pode ter sido publicada no caderno País por se tratar de um hotel que } \\
\text { pertence a uma pessoa famosa. Logo, é de interesse nacional. }\end{array}$ \\
\hline
\end{tabular}




\subsubsection{Síntese da análise textual da Notícia 4}

Percebemos que há, na maioria dos enunciados, um alinhamento prototípico da voz ativa quando o indígena é o sujeito. No entanto, os verbos utilizados nesses casos têm sempre uma semântica negativa. Quando a voz passiva é utilizada, seus argumentos vêm devidamente preenchidos quando o indígena é o agente da passiva.

No campo do discurso, percebemos que uma coerência local é mantida durante todo o texto por meio de sinônimos e contrastes que nos fazem crer que os indígenas são os criminosos e que estão prejudicando pessoas de bem. Além disso, evoca-se, no imaginário do leitor, a figura do indígena que, além de ser selvagem, tem grandes dificuldades para se adaptar à nossa realidade. Eles têm problemas com alcoolismo e, até mesmo, tentam se intrometer na política sem sucesso.

Segundo van Dijk (2003), a estratégia de criar um contraste é muito útil quando se trata de uma tentativa de manutenção do poder, pois fazemos com que as pessoas acreditem que existe uma bipolaridade no mundo: ou se está do nosso lado, praticando boas ações, ou se está do lado deles que agem fora das leis.

No que diz respeito à estrutura da notícia, notamos que o texto traz como informações primárias aquelas relativas à injustiça sofrida pelo hotel de Armínio Fraga. Fala-se em uma ocupação que não tem previsão para acabar. Como informações menos relevantes, o texto traz as motivações indígenas e aborda de maneira superficial a questão da demarcação de terras, apesar de esse ser um problema que vem se arrastando ao longo de anos na história do nosso país.

De maneira geral, a notícia é desfavorável aos Tupinambás, que têm suas reivindicações colocadas em segundo plano. O que ganha destaque é a injustiça que eles estão cometendo contra uma pessoa que tem destaque no meio político-social. Mais uma vez, tanto as estruturas da voz ativa quanto a da voz passiva são utilizadas para acionar frames construídos socialmente: um indígena que invade, é violento, não respeita a propriedade alheia, não sabe esperar pela justiça e que tem um alto índice de alcoolismo entre seus integrantes. As metáforas que se criam são as de crimes e caos.

Van Dijk (1978) afirma que a semântica textual é muito importante para que os frames e modelos mentais corretos sejam ativados. Segundo ele, uma coerência local pode sim influenciar na estrutura como um todo. Os modelos mentais que acionamos para poder compreender um texto dependem antes de tudo da semântica textual, a coerência entre a macroestrutura e a ideologia defendida por uma pessoa são de extrema importância para construir uma linha de raciocínio. Percebemos então, nessa notícia, 
que há uma tentativa de sempre se colocar o indígena como agente da ação, não importa qual voz verbal foi eleita. Isso mantém a teoria de que os indígenas se planejaram, e o crime foi premeditado, não havendo nada que os funcionários pudessem fazer.

\subsection{Síntese geral}

Este trabalho procurou evidenciar como a estrutura linguística contribui para a construção de um estereótipo negativo dos povos indígenas brasileiros. Após as análises, percebemos que há um padrão recorrente nas notícias em todos os níveis verificados.

Encontramos, por exemplo, uma predominância da voz ativa no texto jornalístico, quando o indígena é o sujeito. Além dessa predominância, há também uma recorrência de verbos semanticamente negativos. Isso acontece porque, como explica van Dijk (2003, p. 45),

se queremos tirar ênfase dos nossos pontos negativos e dos pontos positivos deles, tenderemos a tirar da posição de tópico essa informação. Por exemplo, em muitos discursos públicos de uma sociedade multicultural, isso significa que os assuntos associados ao racismo são muito menos levados a público do que aqueles relacionados ao suposto crime, desvios ou supostos problemas causados por grupos minoritários. ${ }^{30}$ (tradução nossa)

A voz passiva, quando é utlizada, aparece quase sempre com o indígena como agente da passiva. Além disso, ele é explícito ou facilmente recuperável/ inferido. Nos textos analisados, essa foi uma estratégia muito utilizada para enfatizar pontos negativos dos indígenas como, por exemplo, terem supostamente matado uma pessoa.

Há uma tentativa constante de ocultar o racismo do dia a dia que ocorre contra as comunidades indígenas. O presidente da Funai João Pedro Gonçalves, em entrevista ao UOL em janeiro de 2016, admitiu a existência de preconceito e esclareceu que os crimes aumentam em decorrência desse racismo:

Tem muita violência contra os povos indígenas e não há, por conta do Estado brasileiro, das instituições, nenhuma conivência. Há um enfrentamento grande e exigimos punição. A Funai repele e repudia essa violência. Tem

\footnotetext{
30 If we want to de-emphasize our bad things and their good things, then we'll tend to de-topicalize such information. For instance, in much public discourse in multicultural society this means that topics associated with racism are much less topicalized than those related to the alleged crimes, deviance or problems allegedly caused by minority groups. (VAN DIJK,2003, p. 45)
} 
sim, no Brasil, setores na sociedade com elevado grau de preconceito contra os povos indígenas. O preconceito aumenta a violência contra os índios.

Gandavo (2004, p.65) mostra que a imagem estereotipada das comunidades indígenas tem suas raízes na época da colonização:

\begin{abstract}
Não se pode numerar nem compreender a multidão de bárbaro gentio que semeou a natureza por toda esta terra do Brasil; porque ninguém pode pelo sertão dentro caminhar seguro, nem passar por terra onde não acha povoações de índios armados contra todas as nações humanas, e assim como são muitos permitiu Deus que fossem contrários uns dos outros, e que houvesse entre eles grandes ódios e discórdias, porque se assim não fosse os portugueses não poderiam viver na terra nem seria possível conquistar tamanho poder de gente. A língua deste gentio toda pela costa é, uma (sic): carece de três letras - scilicet, não se acha nela F, nem L, nem R, cousa digna de espanto, porque assim não têm Fé, nem Lei, nem Rei; e desta maneira vivem sem Justiça e desordenadamente.
\end{abstract}

O documento escrito por Gandavo poderia muito bem ter sido escrito nos dias atuais. Ainda se pensa em um indígena sem leis, sem religião e sem organização política. Esse ainda é o estereótipo indígena que permeia nossas mentes, nos impedindo de enxergar além daquilo que é noticiado. Mais do que isso, o que se constrói no noticiário brasileiro é uma identidade indígena única, que ignora as diversidades culturais e uma identidade congelada no tempo, como se o modo de vida das comunidades indígenas não tivesse se adaptado às novas realidades. É uma identidade realmente inventada (cf. 0.1).

Também se verifica nas notícias uma naturalização de acontecimentos que deveriam ser tratados como ponto de partida para discussões, implementação e fiscalização do cumprimento da legislação vigente. Após visitas aos povos indígenas brasileiros em março de 2016, a relatora da ONU Victoria Tauli-Corpuz destacou que:

Em termos gerais, minha primeira impressão após esta visita é de que o Brasil possui uma série de disposições constitucionais exemplares em relação aos direitos dos povos indígenas, e que no passado o país deixou patente sua liderança mundial no que se refere à demarcação dos territórios indígenas. Entretanto, nos oito anos que se seguiram à visita de meu predecessor, há uma inquietante ausência de avanços na solução de antigas questões de vital importância para os povos indígenas e para a implementação das recomendações do Relator Especial. Ao contrário, houve retrocessos extremamente preocupantes na proteção dos direitos dos povos indígenas, uma tendência que continuará a se agravar caso não sejam tomadas medidas decisivas por parte do governo para revertê-la. 
Ainda segundo a relatora, uma forte preocupação é o grande número de líderes indígenas assassinados. Em 2014, os assassinatos contabilizaram 138 líderes mortos. A maior parte dos crimes aconteceu no Mato Grosso do Sul e é uma forma de represália pela luta indígena no processo de demarcação de terras.

Todas essas informações apresentadas mostram que realmente os frames acionados durante as leituras são os do indígena selvagem: um indígena generalizado, que não pertence à uma comunidade em específico, selvagem, violento e que recorre à ocupações e invasões para fazer justiça com as próprias mãos.

Há uma recorrência dos tópicos "invasão", "morte" e "ocupação" quando os indígenas aparecem nas notícias. Não apenas nas notícias analisadas, mas na maior parte das que foram levantadas, predomina um discurso racista que elege esses tópicos como naturais e inerentes aos povos indígenas. Um exemplo claro disso é a questão da demarcação de terras. Sobre isso, Tauli-Corpuz (2016) destacou que

Há uma representação errônea sobre o que realmente acontece com a demarcação das terras dos povos indígenas em áreas fora da Amazônia, e esse fato embasou minha decisão de visitar essas regiões. Preocupa-me sobretudo a apresentação distorcida da mídia e de outros atores que retratam os povos indígenas como detentores de grandes extensões de terra em comparação com suas populações, quando na verdade é o setor do agronegócio que detém um percentual desproporcional do território brasileiro. (grifos nossos)

Novamente, destaca-se que a maneira como as notícias são construídas inverte os valores, representando os indígenas como os detentores de terras que não lhes pertencem, e os agroempreendedores (e até madeireiros!) como as vítimas desses processos de demarcação de terras. Essa estratégia, em que se cria um grupo oposto ao NÓS, foi apresentada no capítulo 2 (cf. 2.1.4) e apareceu em todas as notícias analisdas nesta dissertação.

Além disso, o espaço ocupado pelas comunidades indígenas na mídia brasileira ainda é muito reduzido, como apresentamos no capítulo 3 (cf. 3.3). Torna-se difícil reverter essa imagem distorcida: há o diminuto espaço ocupado por eles somado às fontes escolhidas para falar sobre eles. Raramente, se escolhe um indígena para ser a fonte da informação. Quando ele é escolhido, os verbos que introduzem sua fala são tipicamente aqueles que retiram o crédito como: dizer e alegar. Tudo isso ainda se agrava com o fato de que a seleção de notícias é feita sem que haja participação, contribuição de grupos indígenas. Não há nem mesmo conhecimento das causas e 
culturas indígenas de quem escreve a notícia. Assim, essas comunidades são sempre retratadas em situações extremas e, normalmente, negativas, sem que sejam ouvidas ou reportadas suas motivações, agonias e reivindicações.

\subsection{Resumo do capítulo}

Neste capítulo apresentamos 4 notícias, textos reais, com a temática indígena. Aplicamos o protocolo apresentado em 3.4, analisando camada por camada o que a sintaxe, o discurso e a estrutura da notícia nos contavam sobre o posicionamento do jornal sobre os envolvidos nos acontecimentos noticiados. Por fim, fizemos uma síntese do que foi observado e percebemos padrões recorrentes nesses textos. Apresentaremos no próximo capítulo essas regularidades e o que elas nos permitem concluir. 


\section{Capítulo 5 - Conclusões}

A partir de todas as análises feitas, podemos concluir que há estruturas que são preferidas pela mídia quando a temática da notícia é indígena (voz ativa, todos os argumento preenchidos, indígenas como sujeitos, agentes e tópicos). As metáforas evocadas são normalmente de GUERRA e CAOS. Não houve nenhuma metáfora que fosse positiva para as comunidades indígenas ou que acionasse frames que contradizessem o senso comum (topoi): os frames sempre eram de indígenas preguiçosos, selvagens, violentos, bêbados e/ou criminosos.

Além disso, as microestruturas definidas por van Dijk aparecem claramente em todas as notícias analisadas, fortalecendo o racismo do dia a dia que se construiu historicamente no Brasil. Os tópicos das notícias favoreciam a construção negativa de uma representação. A evidencialidade era utilizada para descredibilizar as informações dadas pelas autoridades indígenas, por exemplo. A vaguidade também deixa uma lacuna importante no imaginário do leitor. Enquanto enumeram-se as armar utilizadas pelos indígenas, por exemplo, o grupo contrário não é armado na notícia. A lacuna causa a impressão de que o grupo opositor é indefeso e aciona o frame da INJUSTIÇA e da SELVAGERIA. De maneira covarde, sempre se reduzem as identidades indígenas a uma única identidade má que se opõe à justiça e a benevolência.

No que diz respeito à estrutura da notícia, ela é, normalmente, construída de uma maneira prejudicial às comunidades indígenas. Muitas vezes, as notícias massificam, mascaram os interesses indígenas e contribuem para uma construção negativa da representação social dessas comunidades. Além disso, os critérios que normalmente aparecem para noticiar os indígenas são: crime, violência e injustiça. Muito pouco ou praticamente nada se fala dessas comunidades quando esses critérios não estão presentes. Como informação inicial, sempre temos as ações indígenas. Suas motivações, quando citadas, aparecem no final da notícia, sem muito destaque ou detalhes. O que interessa é a injustiça sofrida por um grupo entendido como o NÓS, que se opõe às comunidades indígenas (ELES).

Estamos conscientes, contudo, de que as notícias são resultado de um processo institucionalizado. A publicação de uma notícia não depende apenas de quem produziu o texto. O produto final é resultado de uma seleção feita em conjunto por jornalistas, editores e empresas de comunicação. Martino (2013, p.39) afirma, inclusive, que “ 
desconstruir o discurso jornalístico pode ser entendido como o esforço para identificar as várias vozes dentro da notícia”.

Com este trabalho, demos continuidade a um debate sobre língua, ideologia, identidade, representação, mas percebemos que ainda existe uma lacuna a ser preenchida por pesquisas futuras. Pretendemos futuramente analisar como essas notícias se refletem nos comentários dos leitores, por exemplo. As estruturas analisadas realmente se refletem/repetem quando os comentários são feitos?

Outra questão muito importante a ser analisada é a maneira como esses mesmos acontecimentos são noticiados pelos jornais que trazem um posicionamento próindígena. Podemos analisar até mesmo jornais que são produzidos e veiculados pelas próprias comunidades indígenas.

Esperamos, então, ter começado a analisar como as escolhas gramaticais podem estar a serviço de um fortalecimento de preconceitos e ter provocado em nosso leitor o início de uma reflexão. 


\section{REFERÊNCIAS BIBLIOGRÁFICAS}

ALDÉ, A. ; XAVIER, G. de O. das D.; BARRETOS, D.; CHAGAS, V. Critérios jornalísticos de noticiabilidade: discurso ético e rotina produtiva. Alceu Revista de Comunicação Cultura e Política, Rio de Janeiro, v. 10, 2005.

ALEXANDRE, M. O papel da mídia na difusão de representações sociais. Comum v. 6, n.17, Rio de Janeiro, 2001, p.111 - 125.

ALMEIDA, N. M. Gramática metódica da língua portuguesa. São Paulo: Saraiva, 1977.

ANDREASSEN, L. Introduction to cognitive models. Arhus: University of Aarhus 2002.

ARCE, T. O lead automatizado: uma possibilidade de tratamento da informação para o jornalismo impresso diário. Revista Exacta, Belo Horizonte, v. 2, n. 3, 2009.

Disponível em: <http://revistas.unibh.br/index.php/dcet/article/view/253> Acesso em: $12 / 05 / 2015$.

BAKHTIN, M. Estética da criação verbal. Tradução de Maria Ermantina Galvão G. Pereira. São Paulo: Martins Fontes, 1997.

BAUMAN, Z. Identidade : entrevista a Benedetto Vecchi. Rio de Janeiro : J. Zahar, 2005.

BONINI, A. Gêneros textuais e cognição. Florianópolis: Insular, 2002.

BORBA, F. da S. (Coord.). Dicionário gramatical de verbos do português contemporâneo do Brasil. São Paulo: UNESP, 1990.

BYBEE, J. Language, usage and cognition. Cambridge: Cambridge University Press, 2010.

CAMACHO, R. G. Construções passiva e impessoal: distinções funcionais. ALFA: Revista de Linguística, v. 44, 2000.

CAMACHO, R.G. Estruturas coordenadas aditivas. In: NEVES, M.H.M. (Org.) Gramática do português falado. Novos estudos. São Paulo: Humanitas-USP; Campinas: Editora da UNICAMP, 1999, v. 7, p. 351-406.

CANCLINI, N. G. Consumidores e cidadãos: conflitos multiculturais da globalização. Rio de Janeiro: Editora UFRJ, 2001.

CASTILHO, A. T. A nova gramática do português brasileiro. São Paulo: Contexto, 2010.

Cadernos de estudos lingüísticos, v. 1, p. 13-20, 2012.

CELLARD, A. A análise documental. In: POUPART, J. et al. A pesquisa qualitativa: enfoques epistemológicos e metodológicos. Petrópolis: Vozes, v. 295, p. 2010-2013, 2008.

CHARAUDEAU, P. Discurso das mídias. São Paulo: Contexto, 2013. 
CHIAVEGATTO, V. C. Introdução à linguística cognitiva. Matraga, Rio de Janeiro: UERJ, Instituto de Filosofia e Letras, v. 16, n. 24, p. 77-96, 2009.

COMRIE, B. Language universals and linguistic typology: syntax and morphology. Chicago: University of Chicago press, 1989.

CRESWELL, J. W. Research design: Qualitative, quantitative, and mixed methods approaches, Londres: Sage, 2014.

CROFT, W.; CRUSE, D. A. Cognitive linguistics. Cambridge: Cambridge University Press, 2004.

CRUVINEL, T. Como surgiu a empresa brasil de comunicação?. In: PAULINO, F. O.; SILVA, L. M. (Org.). Comunicação Pública em debate: ouvidoria e rádio. Brasília: Editora Universidade de Brasília, p. 27-39, 2013.

CRYSTAL, D. Dictionary of linguistics and phonetics. Oxford: John Wiley \& Sons, 2008.

CUNHA, C. Gramática do português contemporâneo: edição de bolso. Org. Cilene da Cunha Pereira. Porto Alegre: L\&PM, 2010

DEL'VIGNA, D. O índio no discurso da imprensa escrita. Cadernos de Linguagem e Sociedade, v. 1, n. 1, p. 09, 1995.

DELANCEY, S. The mirative and evidentiality. Journal of pragmatics, v. 33, n. 3, p. 369-382, 2001.

DIK, S. C. Functional grammar. Dordrecht: Foris Publications, 1978.

The structure of the clause. Berlin: Walter de Gruyter, 1997.

DIXON, R. M.W.; AIKHENVALD, A. Y. Changing valency: case studies in transitivity. Cambridge: Cambridge University Press, 2000.

Press, 2003.

Word: a cross-linguistic typology. Cambridge: Cambridge University

DUQUE, P. H.; COSTA, M. A. Linguística congnitiva: em busca de uma arquitetura de linguagem compatível com os modelos de armazenamento e categorização de experiências. Natal: EDUFRN, 2012.

ELHAJJI, M. ANDRADE, D.; RANGEL, L. Contribuições dos estudos críticos do discurso para o campo da comunicação. Lumina, v. 6, n. 1, 2012.

FILLMORE, C. J. Frames and the semantics of understanding. Quaderni di semantica, v. 6, n. 2, p. 222-254, 1985.

FURTADO DA CUNHA, Maria Angélica. Funcionalismo. In: MARTELOTTA, Mário Eduardo. Manual de linguística. São Paulo: Contexto, p. 157-176, 2010.

; BISPO, E. B.; SILVA, J. R. Linguística Funcional centrada no uso:

conceitos básicos e categorias analíticas. In: CEZARIO, M. M.; FURTADO DA

CUNHA, M. A. (Orgs.).Linguística centrada no uso: uma homenagem a mário martelotta. Rio de Janeiro: FAPERJ, 2013. p. 13-39 
GADAMER, H.. Verdade e método I: traços fundamentais de uma hermenêutica filosófica. Petrópolis: Vozes, 2005.

13-27, 1970.

Language and understanding. Theory, Culture \& Society, v. 23, n. 1, p.

GÂNDAVO, P. M.. A primeira história do Brasil: história da província Santa Cruz a que vulgarmente chamamos Brasil. Rio de Janeiro: Jorge Zahar, v. 1576, 2004.

GIACOMELLI, I. L.. Critérios de noticiabilidade e o fotojornalismo. Discursos fotográficos, v. 4, n. 5, p. 13-36, 2008.

GIVÓN, T.. Syntax: an introduction. Amsterdam/Philadelphia: John Benjamins Publishing, 2001.

- A compreensão da Gramática. Traduzido por Maria angélica Furtado da Cunha, Mário Eduardo Martelotta e Felipe Albani. Rio de janeiro: Cortez, 2013.

Voice and inversion. Amsterdam/ Philadelphia: John Benjamins Publishing Company, 1994.

Publishing, 1995.

Functionalism and grammar. Amsterdam/ Philadelphia: John Benjamins

GOLDENBERG, M. A arte de pesquisar. Rio de Janeiro: Editora Record, 2002.

GOMES, D. M. Predicados verbais da língua mundurukú e modelos lexicográficos. Dissertação de mestrado, UnB, Brasília, 2000.

GOMES, D. M. Passiva em Mundurukú (Tupí): uma interseção entre reflexivas/recíprocas e causativas de transitivo. Liames, v. 1, p. 43-53, 2005.

GOMES, D. M.. Estudo morfológico e sintático da língua mundurukú (tupí). 2006. 299f. Tese (Doutorado em Lingüística)-Universidade de Brasília, Brasília, 2006.

GONÇALVEZ, J. P. O preconceito aumenta a violência contra indígenas. 13/01/2016. Brasília, UOL. Entrevista a Leandro Prazeres.

GREGOLIN, M. Análise do discurso e mídia: a (re) produção de identidades. Comunicação, mídia e consumo, v. 4, n. 11, p. 11-25, 2007.

HALL, S. Encoding, decoding. In: HALL, S.; HOBSON, D.; LOWE, D. e WILLIS, P. (Orgs). Culture, Media, Language. Londres: Routledge, 1980.

HECK, E. \& PREZIA B. Povos indígenas: terra é vida. São Paulo: Atual, 1999.

HOPPER, P. J.; THOMPSON, S. A. Transitivity in grammar and discourse. Language, p. 251-299, 1980.

KEENAN, E. L. Some universals of passive in relational grammar. In: Eleventh Regional Meeting of the Chicago Linguistic Society. Chicago: 1975.

KINTSCH, W.; VAN DIJK, T. A. Toward a model of text comprehension and production. Psychological review, v. 85, n. 5, p. 363, 1978.

KLEIMAN, A. Texto e leitor: aspectos cognitivos da leitura. $15^{\text {a }}$ Edição. São Paulo: Pontes, 2003. 
LAKOFF, G. Women, fire and dangerous things. Chicago: University of Chicago Press, 1987.

Moral politics: what conservatives know that liberals don't. Chicago: University of Chicago Press, 1997.

LAKOFF, G.; JOHNSON, M. Metaphors we live by. Chicago: University of Chicago press, 2008.

LAKOFF, G.; TURNER, M. More than cool reason: a field guide to poetic metaphor. Chicago: University of Chicago Press, 2003.

LANGACKER, R. W. Foundations of cognitive gramar. Stanford/Califórnia: Stanford University Press, 1987.

MARTELOTTA, M. E.. Manual de linguística. São Paulo: Contexto, 2010.

MARTELOTTA, M. E.; ALONSO, K. S. Funcionalismo, cognitivismo e a dinamicidade da língua. In: SOUSA, E. R. de. (org.). Funcionalismo linguístico: novas tendências teóricas. São Paulo: Contexto, 2012.

MARTELOTTA, M. E.; PALOMANES, R. Linguística cognitiva. In: Manual de linguística. São Paulo: Contexto, p. 177-191, 2010.

MARTELOTTA, M. E.. Mudança linguística: uma abordagem baseada no uso. São Paulo: Cortez, 2011.

MARTINO, L. M. S.. Teoria da comunicação: ideias, conceitos e métodos. Petrópolis: Vozes, 2013.

MELO, B. Sujeitos sem voz: agenda e discurso sobre o índio na mídia em pernambuco. 2003. 213f. Dissertação (Mestrado). Programa de Pós-Graduação em Comunicação, Universidade Federal de Pernambuco, Recife, 2003.

MOTA, C.. Jornalismo: discurso, narrativa e cultura. In: PEREIRA, Fábio; MOURA, Dione; ADGHIRNI, Zélia (orgs.). Jornalismo e sociedade: teorias e metodologias. Florianópolis: Insular, 2012. p. 205-217.

MOTTA, L. G. Imprensa e poder. Brasília: Editora UnB, 2002.

NEVES, I. S. A invenção do índio: ideologia e história. $O$ Discurso na Contemporaneidade. Araraquara: Claraluz, v. 1, p. 341-351, 2009.

NEVES, I. S.; SILVA, V. L. Análise discursiva e da imagem dos indígenas que foram veiculados no jornal O Liberal nos anos de 1990 e 2011. In: XXXVI CONGRESSO BRASILEIRO DE CIÊNCIAS DA COMUNICAÇÃO, 2013, Manaus, AM. Intercom Manaus 2013- Anais, 2013.

NEVES, M. H. M. et al. Uma introdução ao funcionalismo: proposições, escolas, temas e rumos. In: Funcionalismo e gramaticalização: teoria, análise e ensino. João Pessoa: Idéia, p. 13-28, 2004.

ORLANDI, E. P.. Discurso e leitura. São Paulo e Campinas: Cortez e Editora Unicamp, 1988.

PAYNE, T. E. Describing morphosyntax: a guide for field linguists. New York: Cambridge University Press, 1997. 
Exploring language structure: a student's guide. Cambridge: Cambridge University Press, 2006.

. Understanding english grammar: a linguistic introduction. New York: Cambridge University Press, 2011.

PEZATTI, E. G. Uma abordagem funcionalista da ordem de palavras no português falado. ALFA: Revista de Linguística, 1994, v.38, p.37-56.

PONTE, C. Para entender as notícias: linhas de análise do discurso jornalístico. Florianópolis: Insular, 2005.

PORTO, S. D. Vivências Interpretativas em jornalismo: versão atualizada do método das seis Leituras Interpretativas em massa folhada. In: Jornalismo e sociedade Perira, Dione Adghirni, Zelia (orgs.). Florianópolis: Insular, 2012, p. 181-204.

RAMALHO, V.; RESENDE, V. M.. Análise de discurso (para a) crítica: o texto como material de pesquisa. Campinas: Pontes, 2011.

RODRIGUES, M. Do agenda-setting ao Congresso Nacional: um processo de muitas vias. 2002. Disponível em: <http://www.intercom.org.br/papers/xxici/gt03/gt0304.pdf> Acesso em 15de abril de 2015.

RODRIGUES, T. A.. Buscando sentido para a pesquisa e o ensino de regência verbal: uma abordagem funcional-cognitiva. 2011. 229 f., il. Dissertação (Mestrado em Linguística)-Universidade de Brasília, Brasília, 2011.

SCHNOEBELEN, T. Payne and morphosyntax, 12 de jan. de 2008. 2 f. Notas de aula disponível

<http://web.stanford.edu/ tylers/notes/morphosyntax/Payne_1997_notes.pdf >

Acesso em 25 de outubro de 2013.

SÊGA, R.. O conceito de representação social nas obras de Denise jodelet e serge moscovi. Anos 90, n. 13, Porto Alegre: 2000.

SERVA, L.. Jornalismo e desinformação. São Paulo: Senac, 2001.

SHIBATANI, M. The grammar of causative constructions: a conspectus. In: Syntax and Semantics: The grammar of causative constructions, New York: ed. Masayoshi, 1976. v.61, p. 821-848, 1985.

Passives and related constructions: a prototype analysis. Language,

. The grammar of causation and interpersonal manipulation. Amsterdam: Benjamins, 2001

SCHWANDT, T. Três posturas epistemológicas: interpretativismo, hermenêutica e construcionismo social. In: DENZIN, Norman K.; LINCOLN, Yvonna (orgs). Planejamento da pesquisa qualitativa: teorias e abordagens. 2. ed. Porto Alegre: ARTMED, 2006.

SILVA, G. Para pensar critérios de noticiabilidade. Estudos em jornalismo e mídia, v. 2, n. 1, p. 95-107, 2008a. 
SILVA, M. A notícia como narrativa e discurso. Estudos em Jornalismo e Mídia, v. 4, n. 1, p. 49-64, 2008b.

SILVA, T. T. A produção social da identidade e da diferença. Identidade e diferença, Rio de Janeiro: Vozes, p.73-102, 2010.

SILVA, R. Linguagem e ideologia: embates teóricos. Ling. (dis)curso, Tubarão, v. 9, n. 1, p. 157-180, Apr. 2009 . Disponível em:

<http://www.scielo.br/scielo.php?script=sci_arttext\&pid=S1518-

$76322009000100008 \& \operatorname{lng}=$ en\&nrm=iso>. Acesso em 04 de junho de 2015

SOUSA, J. P.. As notícias e os seus efeitos. 2000. Disponível em <http://bocc.ubi.pt/pag/_texto.php?html2=sousa-pedro-jorge-notícias-efeitos.html> acesso em 25 de outubro de 2013.

TAULI-CORPUZ, V. Relatório sobre povos indígenas. Genebra: Onu. 17/03/2016.

TOMASELLO, M. The cultural origins of human cognition. Cambridge: Harvard University Press, 2009.

THOMPSON, J. B. Ideology and modern culture: Critical social theory in the era of mass communication. Hoboken: John Wiley \& Sons, 2013.

12, n. 1, p. 12-18, 1994.

Ideology and modern culture. South African journal of philosophy, v.

Press, 1984.

. Studies in the Theory of Ideology. Berkeley: University of California

THOMPSON, S. Some issues in chinese functionalism: an Interview with Sandra A.

Thompson, by Chiung-chih Huang, Issues in Applied Linguistics v.5, n.2, p. 409422, 1994.

TRAUGOTT, E, C; DASHER, R. B. The development of modal verbs. In: Regularity in semantic change. Cambridge: Cambridge UP, 2005.

VAN DIJK, T. A. Ideology and discourse. a multidisciplinary introduction.Internet Course for the Oberta de Catalunya (UOC), 2003. Disponível em < http://www.discourses.org/OldBooks/Teun\%20A\%20van\%20Dijk\%20-

\%20Ideology\%20and\%20Discourse.pdf> acesso em 25 de outubro de 2013.

Discurso e poder. São Paulo: Contexto, 2012.

Contexto, 2012.

. Discurso e contexto: Uma Abordagem Sociocognitiva. São Paulo:

. News as discourse. Hillsdale: Lawrence Erlbaum Associates, 1988.

Principles of critical discourse analysis. Discourse \& society, v. 4, n. 2 , 
v. 2, p. 1-37, 1997.

Discourse as interaction in society. Discourse as social interaction, Ideology: a multidisciplinary approach. Londres: Sage, 1998.

. New (s) racism: a discourse analytical approach. Ethnic minorities and the media, Buckingham/ Philadelphia: Open University Press, p. 33-49, 2000.

Critical discourse studies: a sociocognitive approach. Methods of critical discourse analysis. Lodon/New Dehli: Sages, v. 2, n. 1, p. 62-86, 2009.

VAN DIJK, T.; KINTSCH, W.. Strategies of discourse comprehension. New York: Academic Press, 1983.

WELKER, H. A. A valência verbal em três dicionários brasileiros. Revista Linguagem \& Ensino, v. 8, n. 1, p. 73-100, 2012. Disponível em: < http://www.rle.ucpel.tche.br/index.php/rle/article/view/197/164> acesso em 20 de maio de 2014.

WITTMANN, L. T. Introdução Ou a Escrita Da História Indígena In: Wittman, L. T. (ed.), Ensino (D)e história indígena. Belo Horizonte: Autêntica, 2015.

WOLF, M.; FIGUEIREDO, Maria Jorge Vilar de. Teorias da comunicação. Lisboa: Presença, 2009.

WOODWARD, K. Identidade e diferença: uma introdução teórica e conceitual. In: Identidade e diferença: a perspectiva dos estudos culturais. Petrópolis: Vozes, p. 7-72, 2000. 